Estevam Vanale Otero

\title{
As possibilidades e os limites da reabilitação de conjuntos habitacionais em São Paulo
}

Dissertação Apresentada à FAUUSP para Obtenção do Título de Mestre em Arquitetura e Urbanismo

Área de Concentração: Hábitat

Orientador:

Prof $^{\mathrm{a}}$ Dra $^{\mathrm{a}}$ Maria Lúcia Refinetti Martins

São Paulo

2009 
AUTORIZO A REPRODUÇÃO E DIVULGAÇÃO TOTAL OU PARCIAL DESTE TRABALHO, POR QUALQUER MEIO CONVENCIONAL OU ELETRÔNICO, PARA FINS DE ESTUDO E PESQUISA, DESDE QUE CITADA A FONTE.

E-MAIL: estevamotero@yahoo.com

\section{Otero, Estevam Vanale}

O87p As possibilidades e os limites da reabilitação de conjuntos habitacionais em São Paulo / Estevam Vanale Otero. --São Paulo, 2009.

212 p. : il.
Dissertação (Mestrado - Área de Concentração: Habitat) - FAUUSP.
Orientadora: Maria Lúcia Refinetti Martins
1.Habitação 2.Conjuntos habitacionais 3.Política urbana 4.Renovação urbana I.Título


Para Nina 


\section{Agradecimentos}

Gostaria de agradecer a todos aqueles que contribuíram, de uma forma ou de outra, ao desenvolvimento deste trabalho.

Agradeço, primeiramente, à minha orientadora Maria Lúcia Refinnetti Martins, que há anos já me acompanha na minha evolução intelectual, interlocutora privilegiada de minhas agruras acadêmicas e profissionais.

Agradeço, também, aos professores João Sette Whitaker Ferreira e Lizete Maria Rubano, pelas observações pertinentes e valiosas contribuições durante a Banca de Qualificação.

Ao professor Jorge Oseki (in memoriam), grande mestre cuja perda recente fará muita falta a esta escola.

Àqueles que dispuseram de seu tempo e materiais e que foram essenciais à realização da pesquisa: Margareth Uemura, Suely Muniz, Vladimir Bartalini, Altemir Almeida e Renata Milanesi.

A Jefferson Oliveira Goulart, pela leitura atenta do material preliminar e por suas observações e questionamentos que foram fundamentais no aperfeiçoamento do trabalho.

Aos amigos do LABHAB, ambiente estimulante em que amadureci intelectualmente $\mathrm{e}$ onde encontrei grandes companheiros na luta pelo direito à cidade.

Aos colegas do IPPLAP, em especial aos arquitetos João Chaddad e Caio Esteves de Lima, pela compreensão e apoio.

Aos funcionários da biblioteca e do CESAD da FAUUSP, pelo atendimento sempre prestimoso e solícito desde a graduação até a conclusão deste Mestrado.

Aos meus familiares, meus pais e meu irmão, que nunca me faltaram quando precisei neles me apoiar.

Agradeço especialmente a Juliana, parceira de todas as horas, minha mais severa crítica e revisora, sem a qual este trabalho definitivamente perderia muito em qualidade.

E a Nina, que pôde contar menos com o pai do que nós dois gostaríamos. O que esperamos descontar daqui para a frente. 


\section{Resumo}

A presente dissertação objetiva desenvolver uma análise crítica acerca das possibilidades e limites das ações e programas para a reabilitação dos grandes conjuntos habitacionais, especificamente aqueles da COHAB-SP.

Para tanto se procedeu ao exame da evolução do ideário urbanístico e arquitetônico relacionado ao atendimento das demandas por moradia da classe trabalhadora, dos primórdios da Revolução Industrial até o esforço de reconstrução europeu do segundo pós-guerra, com a produção massiva sob a forma conjunto habitacional. A sobreposição de problemas físicos e sociais nesses espaços levou à implementação, a partir da década de 1970, de programas voltados à sua reabilitação; essas propostas são aqui examinadas e avaliadas de acordo com seus objetivos e resultados alcançados, dentro de seus contextos urbanos e socioeconômicos específicos.

Procedeu-se ao exame das ações do Estado brasileiro no campo da habitação popular ao longo do século $X X$, culminando com a instituição do $\mathrm{SFH} / \mathrm{BNH}$, período em que são produzidos os maiores e mais precários conjuntos habitacionais no Brasil. Procurou-se avaliar de que forma a atuação estatal sob a forma da produção dos grandes conjuntos pela COHAB-SP condicionou vastos contingentes populacionais a um cotidiano de segregação e exclusão, reforçando padrões já presentes na estruturação do espaço metropolitano de São Paulo.

Identificadas as características da produção dos grandes conjuntos da COHAB-SP passou-se à análise e avaliação do Programa Viver Melhor, instituído pela Companhia em 2001 especificamente com o intuito de melhorar a qualidade de vida das populações residentes em seus conjuntos; procurou-se identificar as possibilidades e limites na transformação das condições urbanísticas e sociais nesses espaços a partir dessas políticas públicas específicas. 


\section{Abstract}

This dissertation aims at developing a critical analysis of the possibilities and limits of actions and programs for the rehabilitation of large public housing estates, specifically those produced by COHAB-SP.

Therefore, an examination of the development of the urban and architectural ideas related to the meeting of the demands for housing to the working class was carried out, from the beginning of the Industrial Revolution to the effort to rebuild Europe after the Second World War, with a massive production under the housing estate form. The overlapping of physical and social problems in these areas led to the implementation, from the 1970s, of programs aimed at their rehabilitation; these proposals are examined and evaluated here according to their goals and achievements within their specific urban and socioeconomic contexts.

The actions of the Brazilian State in the social housing area during the twentieth century were examined until the establishment of the SFH / BNH, when the biggest and most precarious public housing estates were produced in Brazil. This research sought to evaluate how the state action for the production of large housing estates of COHAB-SP conditioned large groups of population to a routine of segregation and exclusion, reinforcing patterns already present on the structuring of São Paulo's metropolitan space.

After identifying the characteristics of the production of the large public housing estates of COHAB-SP there was the analysis and evaluation of the Programa Viver Melhor, established by the Housing Company in 2001 specifically to improve the life quality of the residents in their sites; the research sought to identify the possibilities and limits to the transformation of the urban and social conditions in these areas from these specific public policies. 


\section{Lista de Ilustrações}

Figura 1 - Karl-Marx-Höf

Figura 2 - Vista lateral do Siedlung Römmerstadt, em Frankfurt

Figura 3 - Vista frontal do Siedlung Römmerstadt, em Frankfurt

Figura 4 - Proposta de Le Corbusier para a cidade do Rio de Janeiro 1930

Figura 5 - Proposta de Le Corbusier para a cidade de Argel - 1930

Figura 6 - Implosão do conjunto habitacional Pruitt-Igoe, Saint Louis, EUA

Figura 7 - Conjunto General Ricardos, Madri, Espanha - estado inicial

Figura 8 - Conjunto General Ricardos, Madri, Espanha - estado remodelado

Figura 9 - Conjunto General Ricardos, Madri, Espanha - vista aérea atual

Figuras 10 e 11 - Reabilitação de conjuntos na França - intervenção em Franc-Moisin

Figura 12 - Mapa dos contratos de Renovação Urbana na França

Figura 13 - Vista aérea dos grandes conjuntos em Clichy-sous-Bois e Montfermeil

Figuras 14 a 19 - Projeto de Renovação Urbana para a aglomeração de Clichy-sous-Bois/Montfermeil

Figura 20 - Taxa de crescimento populacional anual da população na RMSP - 1991/2005

Figura 21 - Taxa de crescimento populacional anual do município de São Paulo - 1991/2005

Figura 22 - São Paulo: área urbanizada 1963-1974 - Terrenos adquiridos pela COHAB-SP entre 1966 e 1974

Figura 23 - São Paulo: área urbanizada 1975-1985 - Terrenos adquiridos pela COHAB-SP entre 1975 e 1985

Figura 24 - São Paulo: área urbanizada 1986-1992 - Terrenos adquiridos pela COHAB-SP entre 1986 e 1996

Figura 25 - Anúncio publicitário da COHAB-SP

Figura 26 - Mapa da População residente, concentração de empregos formais e localização dos conjuntos da COHAB-SP na cidade de São Paulo

Figura 27 - Movimentação de terra no Complexo Santa Etelvina

Figura 28 - Erosões provocadas pela chuva em Cidade Tiradentes

Figura 29 - Conjunto Jardim São Paulo/Juscelino Kubitschek - 1982

Figura 30 - Vista aérea atual do conjunto Santa Etelvina I/VIA e VII

Figuras 31 e 32 - Santa Etelvina IIA - 2002 
160 Figura 33 - Localização do complexo Cidade Tiradentes na cidade de São Paulo

161 Figura 34 - Vista panorâmica dos Santa Etelvina IIIA e IVA - 2008

163 Figura 35 - Imagem de satélite do distrito Cidade Tiradentes - 2007

164 Figura 36 - Mapa dos conjuntos implantados pela COHAB-SP em Cidade Tiradentes

165 Figura 37 - Centro comercial da COHAB-SP em Santa Etelvina I/VIA 2008

165 Figura 38 - Comércios irregulares em Santa Etelvina VII - 2008

167 Figura 39 - Comércios irregulares em Santa Etelvina I/VIA (2008)

167 Figura 40 - Av. dos Têexteis em Santa Etelvina VII (2008)

167 Figura 41 - Comércios irregulares em Santa Etelvina I/VIA (2008)

167 Figura 42 - Comércios irregulares em área verde municipal (2008)

178 Figura 43 - Planta do Projeto-piloto do Programa Viver Melhor em Santa Etelvina IIIA

180 Figura 44 - Projeto-piloto do Programa Viver Melhor: Telecentro (2002)

180 Figura 45 - Projeto-piloto do Programa Viver Melhor: PSF (2002)

180 Figura 46 - CEU Água Azul - Santa Etelvina IIIA (2008)

180 Figura 47 - Hospital Cidade Tiradentes - Santa Etelvina I/IVA (2008) 


\section{Lista de Tabelas}

159 Tabela 1 - Conjuntos Habitacionais da COHAB-SP em Cidade Tiradentes

168 Tabela 2 - Óbitos de Residentes em Cidade Tiradentes por Faixa Etária OMS 1996-2007

181 Tabela 3 - Programa Viver Melhor: intervenções urbanísticas e de implantação de equipamentos

183 Tabela 4 - Programa Viver Melhor: provisão de novas unidades habitacionais

185 Tabela 5 - Programa Viver Melhor: ações de regularização 


\section{Lista de Siglas}

ANAH - Agence Nationale pour l'Amélioration de l'Habitat (Agência Nacional para a Melhoria da Habitação)

ANRU - Agence Nationale pour la Rénovation Urbaine (Agência Nacional para a Renovação Urbana)

BNH - Banco Nacional da Habitação

CDHU - Companhia de Desenvolvimento Habitacional e Urbano do Estado de São Paulo

CEF - Caixa Econômica Federal

CEU - Centro Educacional Unificado

CIAM - Congresso Internacional da Arquitetura Moderna

CNDSQ - Commission Nationale pour le Développement Social des Quartiers (Comissão Nacional para o Desenvolvimento Social dos Bairros)

COHAB-SP - Companhia Metropolitana de Habitação

DETER - Departamento de Terras

DHP-DF - Departamento de Habitação Popular do Distrito Federal

DSQ - Développement Social des Quartiers (Desenvolvimento Social dos Bairros)

DSU - Développement Social Urbain (Desenvolvimento Social Urbano)

FCP - Fundação da Casa Popular

FCVS - Fundo de Compensação das Variações Salariais

FGTS - Fundo de Garantia por Tempo de Serviço

FINASA - Programa de Financiamento para o Saneamento

FNAH - Fonds National d'Amélioration de l'Habitat (Fundo Nacional para a Melhoria da Habitação)

GPU - Grand Projet Urbain (Grande Projeto Urbano)

GPV - Grand Projet de Ville (Grande Projeto de Cidade)

HABI - Superintendência de Habitação Popular

HBM - Habitations à Bon Marché (Habitações a Bom Mercado)

HLM - Habitation à Loyer Modéré (Habitação de Aluguel Controlado)

HVS - Habitat et Vie Sociale (Hábitat e Vida Social)

IAB - Instituto de Arquitetos do Brasil

IAP - Instituto de Aposentadorias e Pensões

IAPI - Instituto de Aposentadorias e Pensões dos Industriários

IBGE - Instituto Brasileiro de Geografia e Estatística

INE - Instituto Nacional de Estadística (Instituto Nacional de Estatística)

INSEE - Institut National de la Statistique et des Études Économiques (Instituto Nacional da Estatística e dos Estudos Econômicos) 
INV - Instituto Nacional de la Vivienda (Instituto Nacional da Habitação)

ISSB - Instituto de Serviço Social do Brasil

IVIMA - Instituto de Vivenda de Madrid (Instituto da Habitação de Madri)

LABHAB - Laboratório de Habitação e Assentamentos Humanos

MDB - Movimento Democrático Brasileiro

ORU - Opérations de Renouvellement Urbain (Operações de Renovação Urbana)

OSH - Obra Sindical del Hogar (Obra Sindical da Moradia)

PAR - Programa de Arrendamento Residencial

PERI - Plan Especial de Reforma Interior (Plano Especial de Reforma Interior)

PLANASA - Plano Nacional de Saneamento

PLANHAP - Plano Nacional de Habitação Popular

PMSP - Prefeitura do Município de São Paulo

PRU - Projet de Rénovation Urbaine (Projeto Intermunicipal de Renovação Urbana)

PSF - Posto de Saúde da Família

RMSP - Região Metropolitana de são Paulo

S.M. - Salário Mínimo

SBPE - Sistema Brasileiro de Poupança e Empréstimo

SCIC - Sociéte Centrale Immobilière de la Caisse de Dépôts (Sociedade Central Imobiliária da Caixa de Depósitos)

SEADE - Fundação Sistema Estadual de Análise de Dados

SEHAB - Secretaria de Habitação e Desenvolvimento Urbano da Prefeitura de São Paulo

SEPLAN - Secretaria de Economia e Planejamento do Estado de São Paulo

SERFHAU - Serviço Federal de Habitação e Urbanismo

SFH - Sistema Financeiro da Habitação

UBS - Unidade Básica de Saúde

ZAC - Zone d'Aménegement Concerté (Zona de Ordenamento Concertado)

ZUP - Zone à Urbaniser en Priorité (Zona de Urbanização Prioritária) 


\section{Sumário}

12

17

\section{Apresentação}

Introdução

Capítulo 1 - A Questão Habitacional nos Países Centrais: da universalização do direito à moradia à luta pelo direito à cidade

$$
\text { 1.1. A Revolução Industrial e o novo mundo urbano }
$$

1.2. O urbanismo moderno

1.3. A habitação no centro da questão urbana

1.4. A reconstrução européia no pós-guerra

1.5. Os programas públicos de reabilitação dos grandes conjuntos habitacionais na Europa

1.5.1. A reabilitação na Espanha

1.5.2. A reabilitação na França

Capítulo 2 - A Atuação do Estado Brasileiro no Campo da Habitação Popular: do Sanitarismo aos Grandes Conjuntos Habitacionais

2.1. Industrialização, urbanização e a atuação do Estado brasileiro no campo da habitação popular no início do século XX
2.2. A política habitacional do regime autoritário de 1964: o Sistema Financeiro da Habitação e o Banco Nacional da Habitação

\subsection{O Estado e a produção dos grandes conjuntos habitacionais}

\section{Capítulo 3 - Conjuntos Habitacionais em São Paulo: Expansão}

\section{Urbana e Segregação Socioespacial}
3.2. A promoção habitacional pública na produção do espaço urbano metropolitano
3.3. Ocupação e consolidação dos conjuntos habitacionais da COHAB-SP
3.3.1. Ocupação e consolidação do complexo Cidade Tiradentes

\section{Capítulo 4 - As Iniciativas e os Programas Públicos de Reabilitação de Conjuntos Habitacionais em São Paulo}

4.1. Antecedentes da reabilitação de conjuntos habitacionais em São Paulo

4.2. Programas públicos de reabilitação dos conjuntos habitacionais em São Paulo: o Viver Melhor

4.3. Perspectivas presentes e futuras à reabilitação dos grandes conjuntos de São Paulo

\section{Considerações Finais}

\section{Referências Bibliográficas}


APRESENTAÇÃO 
A presente pesquisa é fruto do amadurecimento de idéias que, desde 2002, têm instigado o autor a refletir sobre a produção habitacional estatal e seus resultados e impactos no cotidiano de milhares de famílias que têm suas vidas condicionadas por decisões projetuais e burocráticas que fogem completamente ao seu controle.

O ponto de partida para essas indagações deu-se quando integrei a equipe do LABHAB-FAUUSP - Laboratório de Habitação e Assentamentos Humanos da Faculdade de Arquitetura e Urbanismo da Universidade de São Paulo entre o segundo semestre de 2002 e o início de 2003, com o objetivo de desenvolver o Programa Bairro Legal, destinado a desenvolver ações voltadas à reabilitação habitacional e urbana dos distritos mais violentos de São Paulo. À equipe do LABHAB coube desenvolver o plano de ação para o distrito de Jardim Ângela, na zona sul de São Paulo, às margens da represa Guarapiranga, com uma ocupação predominante de favelas e loteamentos clandestinos, numa área sujeita aos rigores das leis de proteção aos mananciais da metrópole.

Além do Jardim Ângela, Vila Brasilândia e Cidade Tiradentes também eram objeto da atuação desse programa. Este último - cujo Plano de Ação esteve a cargo da assessoria técnica USINA-Ctah - constitui-se num dos mais emblemáticos e significativos resultados dessa atuação do poder público na promoção sob a forma conjunto habitacional, representando o maior complexo de moradias públicas da Região Metropolitana de São Paulo e da América Latina, bem como o último grande financiamento de habitação social do BNH antes de sua extinção. Nesse distrito cerca de 150 mil pessoas residem num espaço urbano e numa unidade residencial projetados e construídos sob critérios de maximização das quantidades e minimização dos custos, onde a preocupação com a qualidade de vida desses moradores não era parte integrante das planilhas orçamentárias nem dos memoriais descritivos dos projetos.

A visita a este distrito em outubro de 2002 suscitou questionamentos acerca da tragédia ambiental e urbanística representada por aquela forma espacial, especialmente em sua relação com a distante centralidade metropolitana e a cidade consolidada, e que se traduzia naquele momento nos altíssimos índices de violência naquela região, tendo por principais vítimas seus residentes. O contato com o cotidiano de seus moradores, ainda que breve, produziu em mim um impacto indelével, que as análises e racionalizações sobre a realidade da vida nas "COHABs" não são capazes de reproduzir em todas as suas dimensões.

Despertaram especialmente minha atenção as apropriações e intervenções dos moradores naqueles conjuntos e que, devido à rigidez própria a essa forma urbana, se 
davam, quase sempre, de forma irregular, clandestina, confrontando os projetos originais, de forma a garantir alguma "urbanidade" a esses espaços burocráticos.

A essa época encontrava-se em implementação o programa "Viver Melhor", da COHAB-SP - Companhia Metropolitana de Habitação de São Paulo, resultado do reconhecimento do próprio ente público promotor dessa forma urbana do fracasso do modelo e da necessidade de corrigir os erros do passado, resgatando a dívida para com seus mutuários.

O Viver Melhor consistiu no primeiro programa público desenvolvido em São Paulo com o objetivo manifesto de melhorar a qualidade de vida da população residente em conjuntos habitacionais - nesse caso, aqueles edificados pela COHAB-SP promovendo a inclusão social desses moradores por meio de uma série de ações, sobretudo físicas, na implantação de equipamentos e serviços públicos, procurando reduzir as desigualdades entre esses espaços e as áreas mais infra-estruturadas da metrópole.

Esta iniciativa se coadunava com outras desenvolvidas na Europa, sobretudo na França, com vistas à reabilitação dos grandes conjuntos habitacionais e sua integração física, social e funcional à cidade consolidada, podendo-se dizer que nelas se inspirava e se baseava na formulação de diagnósticos e propostas de intervenção. Ao longo da pesquisa procurar-se-á compreender as características e os resultados das políticas européias de reabilitação dos grandes conjuntos, buscando identificar até que ponto podem se constituir como referência para esse tipo de programa no Brasil.

Faz-se necessário examinar os elementos que caracterizam os grandes conjuntos brasileiros no que tange a sua reconhecida baixa qualidade ambiental e urbanística, procurando identificar de que forma e em que medida estas condições são resultado da política habitacional sob a qual foram gestados, das decisões projetuais tomadas para sua implantação, assim como das condições sociais das populações aí residentes, dentre outros fatores analisados na seqüência.

Com isso em vista buscaremos agregar subsídios para atingir o objetivo dessa pesquisa, que é o de analisar e avaliar o alcance e as limitações da política de reabilitação urbana e ambiental dos grandes conjuntos habitacionais da COHAB-SP, em seu propósito de enfrentar a precariedade dos mesmos e as condições de exclusão social a que se encontram submetidos seus moradores.

O estudo será desenvolvido de modo a tecer um panorama da evolução do ideário urbanístico a partir do surgimento dos problemas advindos da Revolução Industrial, 
notadamente a necessidade de oferecer respostas ao violento crescimento das cidades e de provimento habitacional às classes trabalhadoras.

No Capítulo 1 - "A Questão Habitacional nos Países Centrais: da Universalização do Direito à Moradia à Luta pelo Direito à Cidade" são estudadas e analisadas as idéias e experiências concernentes à promoção habitacional voltada às classes trabalhadoras nos chamados "países centrais do capitalismo", no contexto do Estado de Bem-Estar Social implantado no mundo desenvolvido no pós-Segunda Guerra Mundial.

São expostas as principais ações estatais no enfrentamento da questão habitacional na segunda metade do século $X X$, resultando na produção dos grandes conjuntos, sobretudo na França, atendendo a necessidade da rápida reconstrução demandada após o termino da guerra, bem como combatendo o déficit por moradia já preexistente ao conflito. Devido a uma série de fatores esses espaços acabaram por se tornar o palco da crise urbana e social que vai se instalar no fim do século nesses chamados "bairros em crise". Os sucessivos programas formulados para combater a exclusão social nesses conjuntos são analisados a partir do estudo das experiências espanhola e francesa de fins dos anos 1970 até os dias atuais.

No Capítulo 2 - "A Atuação do Estado Brasileiro no Campo da Habitação Popular: do Sanitarismo aos Grandes Conjuntos Habitacionais" são analisadas as ações formuladas pelo Estado brasileiro com impactos na questão do provimento habitacional às classes trabalhadoras. Para isso foi feita uma avaliação do conjunto de ações implementadas desde os primeiros anos do século $X X$ até o período de maior relevância da atuação estatal, representado pelo auge do sistema SFH/BNH - Sistema Financeiro da Habitação/Banco Nacional da Habitação, momento em que a implantação da forma urbana representada pelos grandes conjuntos habitacionais atinge seu ápice.

No Capítulo 3 - "Conjuntos Habitacionais em São Paulo: Expansão Urbana e Segregação Socioespacial" procedeu-se à identificação dos padrões de segregação que condiciona(ra)m a constituição urbana do território da metrópole paulista, buscando avaliar de que forma a atuação estatal, mais especificamente a política estatal de promoção habitacional, inseriu-se e reforçou esse padrão de desenvolvimento urbano.

Com esse conjunto de elementos o trabalho passa à análise das características principais assumidas pela promoção habitacional sob a forma-conjunto na metrópole de São Paulo, e de que forma as decisões programáticas e projetuais influencia(ra)m e condiciona(ra)m o cotidiano nesses espaços. A partir da avaliação acerca das características assumidas por essa produção procura-se analisar as transformações por que passaram esses espaços ao longo de sua consolidação, objetivando identificar as 
variadas formas de apropriação empreendidas pela população residente, enfocando como estudo de caso específico o Complexo Cidade Tiradentes, maior concentração de grandes conjuntos habitacionais do Brasil e da América Latina.

No capítulo 4 - "As Iniciativas e os Programas Públicos de Reabilitação de Conjuntos Habitacionais em São Paulo" é desenvolvida uma reflexão acerca das políticas públicas implementadas no contexto da Região Metropolitana de São Paulo voltadas ao que chamamos de "reabilitação de conjuntos habitacionais", um conjunto de ações destinadas a melhorar as condições ambientais, físicas e sociais desses espaços produzidos pelo Estado em todas as suas dimensões: da definição do local de implantação, passando pela eleição da população moradora, até as decisões projetuais e construtivas.

Nesse capítulo são avaliados os fundamentos e objetivos das iniciativas implementadas pela COHAB-SP desde fins da década de 1980 até os dias atuais enfocando, especialmente, o período de execução do programa Viver Melhor. Este programa, desenvolvido durante a administração municipal 2001-2004, tinha o objetivo declarado de melhorar a qualidade de vida dos moradores de seus conjuntos habitacionais. Essa análise passou pela distinção das características do programa e de seu processo de implementação. Com isso, procurou-se identificar os resultados efetivos obtidos quanto à melhoria das condições ambientais e urbanísticas, bem como as limitações inerentes a este tipo de atuação.

Esta dissertação vem se juntar a outras pesquisas e estudos que entendem a moradia como um conjunto de serviços e relações que em muito ultrapassam a unidade habitacional, de forma que o direito à habitação passa pelo direito à cidade. Dessa maneira, espera-se, modestamente, contribuir para o aperfeiçoamento das políticas públicas de produção e reabilitação da promoção habitacional estatal, de modo a que as cidades brasileiras possam se tornar mais democráticas e igualitárias, e com uma maior qualidade de vida. 
INTRODUÇÃO 
O Estado capitalista é um ator ativo e altamente relevante tanto na produção quanto no consumo do espaço urbano, uma vez que intermedeia os interesses de seus agentes (os proprietários de terra, as construtoras, os incorporadores imobiliários, os capitais financeiros, os trabalhadores, dentre outros) e as relações entre eles. Ele faz isso ao regular a terra (ao ser um agente promotor de bens de consumo coletivo - estradas, infra-estrutura urbana, serviços públicos, etc -, ao deter os meios reguladores de uso e ocupação do solo, representados pela legislação urbanística, e ao definir a própria localização dos aparelhos do Estado, produzindo externalidades que incidem sobre o valor da terra); ao financiar as duas pontas da atividade imobiliária: tanto a produção quanto o consumo; e ao regular a taxa de salários, dinâmica que influencia a geração de mais-valia no espaço do trabalho tanto quanto a capacidade de consumo do espaço urbano pela força de trabalho.

Ao longo do século XX o Estado brasileiro desempenhou, de forma direta e indireta, por sua presença ativa ou complacência passiva, um papel determinante no processo que resultou na configuração atual de nossas cidades. Especialmente após 1964, com a criação do Banco Nacional da Habitação - BNH, o Estado nacional passa a ser um importante agente tanto na produção quanto no consumo do espaço urbano, ao que alguns autores chegam a considerar que este fato foi fundamental na "estruturação e consolidação de um mercado imobiliário urbano capitalista" ${ }^{1}$ no Brasil. Ainda assim, é neste momento que mais se desenvolvem as formas não-capitalistas de provisão habitacional - como as favelas e os loteamentos clandestinos -, e que vão atender às camadas excluídas desse mercado, funcionando como válvula de escape às demandas por moradia das camadas populares.

Isso levou a que nas metrópoles brasileiras convivam duas realidades urbanas bastante distintas, porém complementares e coerentes com o processo histórico de formação de nossa sociedade: de um lado, as áreas habitadas pelas camadas de alta renda, com alta qualidade urbanística e ambiental, plenamente servidas pelos equipamentos e amenidades públicos ou privados (aquelas integradas ao circuito imobiliário capitalista); de outro, as extensas áreas habitadas pelas camadas populares, quase que invariavelmente carentes de equipamentos e serviços públicos, infra-estrutura urbana, postos de trabalho e consumo, áreas de lazer, entre outros (quase sempre à margem do mercado imobiliário capitalista). Conforma-se, desse modo, o padrão de segregação dominante nas cidades brasileiras, o padrão centro-periferia.

\footnotetext{
${ }^{1}$ MARICATO, Ermínia. Metrópole na Periferia do capitalismo: ilegalidade, desigualdade e violência. São Paulo, Hucitec, 1996, p. 44.
} 
A cidade apresenta-se como local das disputas em torno da apropriação dos diferenciais de localização, palco da luta entre o capital e o trabalho, entre o valor de troca e o valor de $u_{s o}^{2}$, regulados pelo papel ativo do Estado. A disputa em torno das localizações configura nossas cidades como espaços de segregação socioespacial, com componentes econômicos e ideológicos, de forma que "o espaço atua como um mecanismo de exclusão"3.

Contraditoriamente - mas não incoerentemente - parte importante da desigualdade espacial é resultado direto da atuação do Estado nos campos do urbanismo e da habitação popular. Essa contradição se torna ainda mais evidente ao se analisar a política habitacional materializada nos grandes conjuntos habitacionais edificados pela COHAB-SP na periferia da Região Metropolitana de São Paulo, principalmente ao longo das décadas de 1970 e 1980, espaços em que o enfoque quantitativo da produção passou muito longe de promover o "direito à cidade" a essas populações.

VILLAÇA analisa a segregação urbana nas metrópoles brasileiras enquanto processo de estruturação do espaço urbano, a partir do estudo da formação e localização das zonas de moradia ocupadas pelos estratos de alta e média rendas e aqueles setores onde se encontram as moradias das classes trabalhadoras, uma vez que identifica na localização das zonas residenciais e industriais os principais fatores estruturadores do espaço metropolitano no Brasil. A produção da segregação seria, ainda, um processo dialético, em que a luta pelas melhores localizações no espaço urbano implicaria na existência de vencedores e perdedores, em que a segregação auto-imposta por uns acarretaria, igualmente, na imposição da segregação aos derrotados ${ }^{4}$. Alguns autores já identificam uma alteração no padrão de segregação no Brasil, sobretudo na metrópole de São Paulo no período mais recente, com relação aos novos espaços produzidos a partir das décadas de 1980 e $1990^{5}$.

Para efeito desta pesquisa, o padrão de segregação centro-periferia segue sendo uma importante referência teórica para a compreensão da estruturação do espaço, pois foi dentro dessa referência que se produziu a quase totalidade das unidades habitacionais construídas pela COHAB-SP na Região Metropolitana de São Paulo, nas franjas da área

\footnotetext{
${ }^{2}$ Cf. MARICATO, Ermínia. Indústria da Construção e Política Habitacional. São Paulo: São Paulo: Tese de doutorado apresentada à FAUUSP, 1984, p. 108.

${ }^{3}$ VILLAÇA, Flávio. Espaço Intra-urbano no Brasil. São Paulo: Nobel, 2001, p. 143.

${ }^{4}$ Cf. VILLAÇA, Flávio. Op. Cit., 2001, p. 147-8.

${ }^{5}$ CALDEIRA, Teresa Pires do Rio. Cidade de Muros: crime, segregação e cidadania em São Paulo. São Paulo: EDUSP: 34, 2000.
} 
urbanizada da metrópole, contribuindo a atuação do poder público na reprodução desse padrão de segregação.

CALDEIRA avalia que a radicalização desse processo segue em curso, uma vez que as distintas classes sociais na cidade de São Paulo, além de não compartilharem os espaços de moradia, caminham para não mais compartilhar os espaços públicos na cidade. As camadas de alta e de baixa renda realizariam circuitos distintos, só se interrelacionando, eventualmente, no mundo do trabalho, tendo por resultado "segregação, distância social e exclusão e a implosão da experiência de vida pública na cidade moderna"6.

Esse caráter segregacionista do espaço não seria um "privilégio" de metrópoles periféricas, caso de São Paulo. Com uma evidente diferença na escala e intensidade desses níveis de segregação, LEFEBVRE identifica o mesmo processo na constituição do espaço na metrópole parisiense, onde "o proletariado ainda não teria criado um espaço: a burguesia mercantil, os intelectuais, os homens de Estado, modelaram a cidade. Os industriais, antes de tudo, demoliram-na. Quanto à classe operária, não teve outro espaço que o da sua expropriação, da sua expulsão: da segregação"7, da qual decorreria uma completa "desagregação da vida mental e social".

Diferentemente do caso brasileiro (onde a produção habitacional pública sob a forma de conjuntos habitacionais ainda não é o auge da segregação e da alienação urbanas), na França a promoção habitacional estatal sob a forma dos grands ensembles periféricos acirrou e reproduziu as condições de segregação. Isso decorre do fato de que lá os grandes conjuntos suburbanos abrigam, efetivamente, os mais baixos estratos sociais, acumulando toda uma sorte de carências e problemas os mais diversos; aqui, pelas próprias características da política habitacional ${ }^{9}$, os conjuntos, normalmente, abrigam populações um degrau (ou vários) acima daquelas que só vão encontrar nas favelas e loteamentos clandestinos periféricos a possibilidade de acesso à moradia.

Nos países centrais do capitalismo o Estado interveio diretamente na produção massiva de habitações - especialmente após a Segunda Guerra Mundial, quando a

\footnotetext{
${ }^{6}$ CALDEIRA, Teresa Pires do Rio. Op. Cit., 2000, p. 301.

${ }^{7}$ LEFEBVRE, Henri. A Revolução Urbana. Belo Horizonte: Editora UFMG, 1999, p. 119.

${ }^{8}$ LEFEBVRE, Henri. Op. Cit., 1999, p. 160. (grifo no original).

${ }^{9}$ A política habitacional implementada sob a forma conjunto habitacional sob a égide do BNH objetivava o atendimento tão somente da demanda "solvável". Aquelas camadas sociais que não conseguissem atender os pré-requisitos para receber o financiamento do banco estariam automaticamente excluídas da política habitacional pública. Dessa forma os conjuntos contam, de modo geral, com uma população com uma condição socioeconômica superior a de outras realidades urbanas ainda mais precárias.
} 
produção estatal de habitações de interesse social chegou a representar, em determinado momento, mais de $50 \%$ da produção total de habitações - exceção feita aos EUA, onde essa produção era "marginal"10 - integrando à cidade e à sociedade de consumo de massa grandes contingentes populacionais por meio de políticas de cunho keynesiano, no contexto do Estado de Bem-Estar Social que se implantava na Europa.

Diversamente, nos países do capitalismo periférico, caso do Brasil, a expansão capitalista se deu de forma concentradora e desigual, integrando, de maneira subalterna, tanto essas nações quanto as maiorias que as habitam. Novamente, não se quer dizer, aqui, que nos países centrais essa integração à cidade tenha sido plena, muito pelo contrário, como já constatava LEFEBVRE nas décadas de 1960 e 1970, configurando-se os grands ensembles franceses no caldeirão sempre prestes a explodir. Em conferência proferida em janeiro de 1970 ele já antevia o mal-estar social nos grande conjuntos e as perspectivas para o futuro, com mais de uma década de antecedência:

Nesse caso, ocorrerá algo de extremamente grave: uma espécie de transferência do colonialismo na metrópole, um semicolonialismo das regiões e das zonas mal desenvolvidas em relação aos centros de decisão e, sobretudo, ao centro parisiense; não existem mais colônias no sentido antigo, mas já há um semicolonialismo metropolitano que subordina a esses centros elementos camponeses, operários estrangeiros em número considerável, em seguida também muitos franceses pertencentes seja à classe operária, seja mesmo à intelectualidade, o todo submetido a uma exploração, concentrada quanto aos métodos, mas mantendo os elementos em estado de segregação espacial. (...) É inútil dizer que essa situação seria explosiva ${ }^{11}$.

A explosão de violência nos subúrbios expôs todas as contradições desses espaços produzidos e moldados à feição do Estado, especialmente quando essa violência se viu canalizada, preferencialmente, contra seus aparelhos e agentes.

Há que se atentar, contudo, para o fato de que nos países periféricos persistiu um relativo descaso às demandas habitacionais das camadas de mais baixa renda. Mesmo as populações integradas ao circuito do capitalismo global, como os trabalhadores da indústria automobilística, fizeram uso de expedientes irregulares/clandestinos para dar conta de atender suas demandas por moradia, uma vez que nem os salários pagos por essa indústria nem as políticas públicas habitacionais apresentavam-se como adequadas às suas necessidades ${ }^{12}$.

${ }^{10}$ Cf. FARAH, Marta Ferreira dos Santos. Público e Privado na Provisão de Habitação nos Países Centrais. Revista Espaço e Debates 31. São Paulo: NERU, 1990, p. 14.

${ }^{11}$ LEFEBVRE, Henri. Espaço e Política. Belo Horizonte: Editora UFMG, 2008, p. 77. Grifo nosso.

${ }^{12}$ Cf. MARICATO, Ermínia. Metrópole na periferia do Capitalismo: ilegalidade, desigualdade e violência. São Paulo: Hucitec, 1996, p. 43. 
A fim de compreender o fenômeno da segregação recorremos a MARCUSE, que procura estabelecer uma distinção entre formas aceitáveis e aquelas socialmente indesejáveis de segregação, sob um ponto de vista que diz respeito muito mais às características socioespaciais estadunidenses que brasileiras, mas que nos interessam por identificar no Estado um dos principais responsáveis pela instituição, perpetuação e, correlatamente, na possibilidade de enfrentamento do problema da segregação.

Para MARCUSE a segregação seria decorrência da articulação entre três distintos grupos/tipos ideais sob os quais se estruturariam os variados segmentos sociais, definidos a partir de características sociais distintivas e homogeneizadoras: as distinções culturais, o papel funcional e econômico de determinado grupo social e sua posição na hierarquia do poder $^{13}$. Cabe ressaltar que o autor identifica aspectos positivos na autosegregação de determinados grupos, sob a pretensa defesa de características culturais ou funcionais inerentes aos mesmos; por outro lado, a segregação decorrente de distinções de hierarquia e status deveria a todo custo ser combatida ${ }^{14}$. MARCUSE parece relevar, em sua avaliação positiva de certas formas de segregação auto-imposta, o aspecto dialético que a segregação assume no processo de constituição desses espaços, uma vez que a auto-segregação de alguns implica, necessariamente, na segregação do outro, do diferente, do indesejável, como bem observa VILLAÇA ${ }^{15}$.

Dentre as considerações de MARCUSE, tem para nós especial interesse sua leitura sobre o papel do Estado na promoção da segregação - e na sua eventual eliminação - assim como a instituição do instrumental técnico-político do planejamento urbano a serviço da segregação urbana, sobretudo o zoneamento urbano ${ }^{16}$.

Com relação à produção dos grandes conjuntos habitacionais na RMSP essa observação é bastante pertinente, uma vez que a própria viabilização dessa forma urbana

13 Cf. MARCUSE, Peter. Enclaves, sim; Guetos, não: a Segregação e o Estado. Revista Espaço e Debates 45. São Paulo: NERU, 2004, p. 26.

14 Ressalve-se que essa observação de Marcuse acerca dos aspectos positivos da segregação social como meio de se preservar traços culturais, étnico e lingüísticos diz muito sobre o ambiente social estadunidense onde foi formulada, marcado pelo multiculturalismo; no caso brasileiro, o estudo da segregação se aproxima muito mais da forma como ele se dá na França, sob uma perspectiva analítica que privilegia a distinção entre categorias socioeconômicas, em lugar das étnico-raciais. Para mais detalhes acerca dessa diferença entre formas de abordar e estudar a questão da segregação urbana ver PRÉTECEILLE, Edmond. A construção social da segregação urbana: convergências e divergências. in Revista Espaço \& Debates 45 - Segregações Urbanas. São Paulo: Neru - jan/jul 2004.

${ }^{15}$ Cf. VILLAÇA, Flávio. Op. Cit., 2001, p. 148.

16 Acerca desse ponto são relevantes suas observações sobre o papel segregador inerente ao zoneamento urbano, uma vez que implica diretamente na definição dos valores das localizações urbanas. Ele cita diretamente a definição de zonas onde é proibida a construção de habitações multifamiliares, claramente destinada a impedir a viabilização de moradias baratas às camadas de mais baixa renda. Cf. MARCUSE, Peter. Op. Cit., 2004, p. 26. 
se deu pela instituição de uma zona específica para esse fim - a Z8-100/1 - de modo a permitir ao poder público atuar em áreas com características (legalmente) rurais. Sob a argumentação (falaciosa) de que isto viabilizaria grandes porções de terra barata para fins sociais, o zoneamento foi utilizado como forma de afastar as camadas populares (e suas demandas) das áreas consolidadas, evitando assim a disputa por terras de interesse do capital especulativo.

Para o caso brasileiro e paulistano, especificamente, MARQUES identifica a periferia como um fenômeno heterogêneo e complexo, comportando diferentes graus de cumulatividade de carências, conformando espaços heterogêneos em relação às condições de vida e demanda por serviços e equipamentos ${ }^{17}$. Há, evidentemente, grandes diferenças entre os graus de carência presentes num loteamento clandestino periférico, numa favela ou num grande conjunto habitacional. Nesse caso, as próprias características originárias de cada uma dessas áreas acaba por conferir grande heterogeneidade às demandas e ao cotidiano vivido por cada uma dessas populações. Ressalte-se, ainda, que o próprio grau de consolidação, tempo decorrido da ocupação e posição relativa ao conjunto da metrópole acabam por impactar de maneiras diferentes o cotidiano de cada população, demandando abordagens específicas e adequadas a cada situação. Contudo, é fundamental atentar para que, a despeito das especificidades e da heterogeneidade do conjunto da periferia, não se perca de vista o processo que levou à constituição dessa vasta periferia, marcado pela super-exploração da força de trabalho, decorrente de nosso modelo de "industrialização com baixos salários".

Conforma-se, desse modo, uma ocupação desigual do território do que decorrem, por sua vez, desigualdades sociais associadas ou inscritas no espaço urbano. Essas desigualdades espaciais, bastante relacionadas à segregação e à pobreza urbanas, teriam por correlato a desigualdade de "acesso ao mercado de trabalho (que gera oportunidades diferenciadas) e acesso às políticas públicas (que geram as amenidades e os serviços que caracterizam a vida urbana)"18.

Como se pretende demonstrar ao longo do trabalho, as questões que envolvem a segregação e a alienação urbanas observadas no interior dos grandes conjuntos habitacionais extrapolam sua circunscrição territorial; na maior parte das vezes esses problemas vinculam-se a dinâmicas sociais muito maiores e mais complexas, cujo

\footnotetext{
${ }^{17}$ MARQUES, Eduardo. Elementos conceituais da segregação, da pobreza urbana e da ação do Estado in MARQUES, Eduardo e TORRES, Haroldo (Org.). São Paulo: segregação, pobreza e desigualdades sociais. São Paulo: SENAC, 2005a.

${ }^{18}$ MARQUES, Eduardo. Op. Cit., 2005a, p. 42.
} 
enfrentamento deve ultrapassar o objeto segregado e alcançar o processo que constituiu essa realidade ${ }^{19}$.

A própria política levada a cabo pela COHAB-SP na promoção dos grandes conjuntos periféricos, fundada na justificativa econômica do empreendimento, produziu e acirrou a segregação na metrópole paulista ${ }^{20}$. As características inerentes a essa forma urbana constrangem seus residentes a um cotidiano precário e alienado.

Para MARQUES, uma das formas de se efetivar o enfrentamento das desigualdades sociais e da segregação no espaço deveria se dar por meio da intervenção maciça em melhorias das condições urbanas das áreas habitadas pelas populações pobres, aproximando seu padrão urbano daquele dos outros bairros da cidade legal. Essas estratégias agiriam tanto dentro do âmbito das políticas sobre o espaço físico, como das políticas sociais como educação, saúde e políticas de transferência de renda, por exemplo, e sempre associadas a mecanismos de regulação urbana para que possa haver um real controle sobre as dinâmicas urbanas ${ }^{21}$.

Essa estratégia ofereceria a possibilidade de proceder a melhorias significativas na qualidade de vida na periferia (de modo geral) e nos grandes conjuntos (em particular) por meio da implementação maciça de equipamentos e serviços, públicos e privados. Estaria limitada, contudo, no que se refere à superação dos mecanismos produtores da exclusão e segregação em sua acepção mais ampla: ainda que apresentem níveis de infraestrutura equiparáveis às demais áreas da cidade, os grandes conjuntos ainda serão perímetros constrangidos por sua localização distante, sua morfologia e tipologia rígidas e monótonas, além da concentração das populações socialmente mais fragilizadas. Ainda assim, poderiam representar uma melhoria urbana significativa nesses territórios.

Sob essa perspectiva de enfrentar as desigualdades socioespaciais por meio do investimento em equipamentos e serviços públicos foram realizadas algumas ações e políticas públicas destinadas a melhorar a qualidade de vida nos grandes conjuntos habitacionais da COHAB-SP, notadamente durante a administração municipal 2001-2004,

19 Essa dinâmica será objeto de análise no capitulo 1 deste trabalho, em que serão examinados a degradação física e social e os programas públicos de reabilitação ambiental e urbanística em grandes conjuntos habitacionais na Europa, e no capítulo 4, que trata das ações de reabilitação de conjuntos na cidade de São Paulo.

20 Alguns autores, como SILVA, desmontam essa argumentação, pois o custo final da unidade habitacional produzida na periferia da metrópole apresentava-se bastante elevado, pela própria necessidade de se implantar toda uma complexa infra-estrutura no local. Cf. SILVA, Helena Menna Barreto. Políticas de Habitação e Preço da Terra in Revista Oculum Ensaios - dezembro de 2000. Campinas: FAU PUCCAMP, 2000. Esse tema será melhor analisado no capítulo 3 - "Conjuntos Habitacionais em São Paulo: Expansão Urbana e Segregação Socioespacial".

${ }^{21}$ Cf. MARQUES, Eduardo. Op. Cit., 2005a, p. 50. 
quando se elaborou um programa especificamente voltado a esse fim. Mesmo sem objetivar efetivamente o enfrentamento da segregação até sua superação essas ações apresentam-se como possibilidades de reabilitar social e fisicamente os perímetros dos grandes conjuntos habitacionais paulistanos.

Serão analisadas de que maneira essas ações e programas de reabilitação foram bem sucedidos em integrar social, funcional e urbanisticamente os grandes conjuntos produzidos pela COHAB-SP por meio de investimentos em equipamentos e serviços públicos. Serão objeto de análise as ações e programas - em projeto ou implementadas de acordo com seus objetivos e os resultados buscados e/ou alcançados, bem como seus problemas e limitações quanto às possibilidades de se reverter as condições de segregação e alienação urbanas a que estão sujeitos esses espaços. 
CAPÍTULO 1

A QUESTÃO HABITACIONAL NOS PAÍSES CENTRAIS:

DA UNIVERSALIZAÇÃO DO DIREITO À MORADIA À LUTA PELO DIREITO À CIDADE 
Em fins do século XVIII uma dinâmica implantou-se no planeta que viria a alterar por completo a compreensão de mundo que as gerações precedentes haviam vivenciado. A Revolução Industrial veio representar uma radical ruptura entre as formas de vida do passado, extremamente vinculadas à terra e ao meio rural, e o novo mundo urbano que estava surgindo.

Esse processo de vertiginosa urbanização, associado à alteração de toda a base social e produtiva que passava a se assentar sobre o trabalho assalariado na indústria nascente, produziu cidades assombrosamente precárias, insalubres, fétidas, repugnantes a inúmeros de seus contemporâneos, horrorizados com o espetáculo dantesco representado pela atividade fabril intensamente poluidora e a massa trabalhadora submetida a condições subumanas de moradia. Este contexto gerou uma vigorosa produção intelectual de crítica à cidade industrial, motivando desde a ideologia anti-urbana burguesa até as propostas dos socialistas utópicos. Contudo, dificilmente estes estudos reconheciam nesse aparente caos e desordem o produto de uma nova ordem que se estabelecia no continente europeu: a expansão e consolidação do modo de produção capitalista. Daí que grande parte das propostas do período negava os resultados do processo, sem compreender-lhe as origens, o que levou a que mesmo muitas das mais progressistas formulações do período acabassem por negar a cidade, identificando o espaço, e não as condicionantes que o geravam, como responsável pelos males da sociedade urbana dos primórdios da Revolução Industrial. Esses ideais preconizavam uma ampla reforma, que representaria uma verdadeira ruptura com o modo de vida precedente, a fim de enfrentar as novas questões que eram colocadas pela Revolução Industrial, beneficiando-se das novas possibilidades que se abriam no momento. Para isso seria fundamental a edificação de uma nova urbanidade, capaz de abrigar um novo homem, célula da nova sociedade que se formava. Esses conceitos vão embasar inúmeras experiências e propostas importantes no campo da habitação social, especialmente ao longo do século XX.

Interessa-nos estudar e analisar o percurso das idéias acerca da habitação social de promoção estatal, desde seu surgimento como demanda às precárias condições de vida da classe trabalhadora nos primórdios da Revolução Industrial, passando por sua condução ao centro do debate arquitetônico a partir dos anos 1920, para onde foi alçada no auge do Movimento Moderno, até a crítica e falência do modelo dos grandes conjuntos habitacionais, que marca a década de 1970, na Europa e na América do Norte, ainda que isto não represente o fim da intervenção estatal no campo da moradia popular, mas uma inflexão que se deve muito a uma mudança drástica do ambiente econômico e social, com a redefinição do papel do Estado que se verifica ao redor do mundo a partir de fins dos anos 1970. 
Assim, reconstituiremos os principais conceitos e debates realizados nesse período, com o intuito de superar os problemas iniciais da moradia proletária, bem como identificar as principais experiências que se constituíram marcos divisórios na evolução das soluções habitacionais destinadas às classes trabalhadoras, idéias e experiências estas que serviram de modelo e inspiração às iniciativas do Estado brasileiro no campo da habitação popular, no mais das vezes de maneira acrítica e de forma absolutamente inapropriada às condições, características e contexto nacionais.

\subsection{A Revolução Industrial e o Novo Mundo Urbano}

A Revolução Industrial, processo de longo amadurecimento no decorrer dos séculos XVIII - em seus primórdios na Inglaterra - e XIX - quando ganha velocidade e estende-se sobre o continente europeu, sobretudo em sua porção setentrional - trouxe em seu bojo uma completa reorganização territorial, resultado do rápido afluxo de populações rurais às cidades, num violento processo de urbanização que teve como reflexo a deterioração ambiental e as péssimas condições de salubridade dos aglomerados urbanos que surgiram e cresceram sob a demanda dos cada vez maiores contingentes da força de trabalho.

Esse processo, que resultou no inchaço das novas metrópoles industriais, alimentou-se da grande migração dos campos para as cidades, de populações que perdiam a possibilidade de viver dos frutos de seu trabalho na terra como seus antepassados fizeram nos séculos precedentes, e que, premidos pela necessidade de sobrevivência, viam-se obrigados a migrar para as cidades, indo compor o exército industrial de reserva das nascentes indústrias ${ }^{1}$. O corolário desse desenvolvimento foi o surgimento de aglomerações urbanas de proporções tais que com dificuldade a imaginação da época pôde conceber.

\footnotetext{
${ }^{1}$ Outro importante fator na rápida urbanização foi a queda das taxas de mortalidade, que propiciou um rápido crescimento demográfico nos países da Europa Ocidental. A Inglaterra passou de 8.892 .000 de habitantes em 1801 para cerca de $14.000 .000 \mathrm{em}$ 1831, graças à redução da taxa de mortalidade, que passou de 35,8 (na década de 1730-40) para 21,1 por 1.000 habitantes (na década 1811-21), ao mesmo tempo em que a taxa de natalidade mantinha-se relativamente estável em torno de 37 por mil. Isso se deveu, sobretudo, a questões de ordem higiênica, como a melhoria na alimentação, na higiene pessoal e aos avanços da Medicina. Cf. BENEVOLO, Leonardo. História da Arquitetura Moderna. São Paulo: Perspectiva, 2006, p. 21. Londres, que contava com 864.845 habitantes em 1801 passou a 1.873.676 quarenta anos depois, chegando a 4.232.118 em 1891. Entre 1800 e 1895 o número de cidades inglesas com mais de cem mil habitantes saltou de duas para trinta; na Alemanha, no mesmo período, estas passam de duas para vinte e oito, enquanto na França, vão de três para doze. Cf. CHOAY, Françoise. Urbanismo: utopias e realidades - uma antologia. São Paulo: Perspectiva, 1997, p. 3. Manchester, um dos mais importantes centros fabris do século XIX, passou de 75.000 habitantes em 1801 para 600.000 um século depois. Cf. FRAMPTON, Kenneth. História Crítica da Arquitetura Moderna. São Paulo: Martins Fontes, 2003, p. 14.
} 
O exemplo mais completo e bem acabado do que foi a expulsão das populações camponesas para compor os exércitos operários habitando as periferias das grandes cidades industriais ocorreu na Inglaterra, onde os cercamentos promovidos pelos landlords resultaram na expulsão dos camponeses, que habitavam e extraíam seu sustento dessas terras comunais desde a Idade Média, para a criação das mais rentáveis ovelhas, fornecedoras de lã, matéria prima essencial para a indústria nascente.

Esse processo foi descrito com brilhante precisão por MARX n'O Capital, ao tratar da Acumulação Primitiva. Mediante as mais variadas fraudes e violências, o trabalhador rural teve cortado seu vínculo com a terra e não teve outra alternativa que vender sua força de trabalho nas cidades:

O roubo dos bens da Igreja, a alienação fraudulenta dos domínios do Estado, a ladroeira das terras comuns e a transformação da propriedade feudal e do clã em propriedade privada moderna, levada a cabo com terrorismo implacável, figuram entre os métodos idílicos da acumulação primitiva. Conquistaram o campo para a agricultura capitalista, incorporaram as terras ao capital e proporcionaram à indústria das cidades a oferta necessária de proletários sem direitos ${ }^{2}$.

Esses trabalhadores desenraizados, residindo nos incontáveis slums que proliferavam nas cidades industriais de Londres, Birmingham ou Manchester, em condições precárias e insalubres, trabalhando longas jornadas, sete dias por semana, escandalizaram diversos contemporâneos, os quais identificaram na Revolução Industrial em curso o marco divisório a partir do qual não era mais possível conceber a cidade e a sociedade como até aquele momento. Novos olhares e novas abordagens seriam necessários ao enfrentamento das questões que envolviam a intensa urbanização e a ruptura com o passado que se verificava. Contudo, o valor que se atribuiu a este momento variou grandemente e apresentou sinais trocados, de acordo com o autor contemporâneo que analisou o processo em pleno curso dos acontecimentos, cujos resultados ainda não estavam completamente consolidados e claros.

ENGELS descreve com riqueza de detalhes e grande precisão as péssimas condições de vida dos operários ingleses em 1845:

Todas as grandes cidades têm um ou vários "bairros de má fama" onde se concentra a classe operária. É certo ser freqüente a miséria abrigar-se em vielas escondidas, embora próximas aos palácios dos ricos; mas, em geral, é-lhe designada uma área à parte, na qual, longe do olhar das classes mais afortunadas deve safar-se, bem ou mal, sozinha. Na Inglaterra, estes "bairros de má fama" se estruturam mais ou menos da mesma forma que em todas as cidades: as piores casas na parte mais feia da cidade; quase sempre, uma longa fila de construções de tijolos, de um ou dois andares, eventualmente com porões habitados e em geral

\footnotetext{
${ }^{2}$ MARX, Karl. O Capital: crítica da economia política. Livro 1, Volume 2. Rio de Janeiro: Civilização Brasileira, 2006, p. 847.
} 
dispostas de maneira irregular. Essas pequenas casas de três ou quatro cômodos e cozinha chamam-se cottages e normalmente constituem em toda a Inglaterra, exceto em alguns bairros de Londres, a habitação da classe operária. Habitualmente, as ruas não são planas nem calçadas, são sujas, tomadas por detritos vegetais e animais, sem esgotos ou canais de escoamento, cheias de charcos estagnados e fétidos. A ventilação na área é precária, dada a estrutura irregular do bairro e, como nesses espaços restritos vivem muitas pessoas, é fácil imaginar a qualidade do ar que se respira nessas zonas operárias - onde, ademais, quando faz bom tempo, as ruas servem aos varais que, estendidos de uma casa a outra são usados para secar roupa ${ }^{3}$.

BENEVOLO vai chamar essa metrópole inabitável que nasce da Revolução Industrial de "cidade liberal", cuja aparente desordem e caos eram produto direto das idéias professadas pelos radicais defensores do liberalismo econômico, uma vez que era

o resultado da superposição de muitas iniciativas públicas e particulares, não reguladas e não coordenadas. A liberdade individual, exigida como condição para o desenvolvimento da economia industrial, revela-se insuficiente para regular as transformações de construção e urbanismo, produzidas justamente pelo desenvolvimento econômico ${ }^{4}$.

No alvorecer do século XIX surgiram os primeiros estudiosos que se debruçaram sobre a questão urbana, formulando as propostas iniciais para o enfrentamento dos problemas nascidos com a Revolução Industrial. Conforme análise de CHOAY, esse incipiente conjunto era composto por pensadores de formação bastante heterogênea, de cunho generalista, como historiadores, economistas ou políticos. Contudo, esses primeiros estudiosos concluíram, equivocadamente, que os problemas eram fruto do "caos", da "anarquia", da "desordem", sem compreender que se tratava, pelo contrário, do estabelecimento de uma nova ordem advinda da Revolução Industrial ${ }^{5}$.

A esse conjunto de estudos, análises e propostas ela chamou de pré-urbanismo, que tinha sua unidade na crítica à cidade e à sociedade industriais. Dentre os quatro campos que ela identifica como componentes desse grupo interessa-nos aquele a que denomina de "modelo progressista", corrente cuja subseqüente evolução e desenvolvimento resultará nas propostas urbanas características do período moderno, especialmente os grandes conjuntos habitacionais, que serão objeto de especial reflexão ao longo deste trabalho ${ }^{6}$.

${ }^{3}$ ENGELS, Friedrich. A Situação da Classe Trabalhadora na Inglaterra. São Paulo: Boitempo, 2008, p. 70.

${ }^{4}$ BENEVOLO, Leonardo. História da Cidade. São Paulo: Perspectiva, 2007, p. 567.

${ }^{5}$ Cf. CHOAY, Françoise. Op. Cit., 1997, p. 6-7.

${ }^{6}$ Internamente ao conjunto de idéias que ela define como pré-urbanismo, Choay faz uma distinção entre quatro campos principais, em decorrência dos quais serão desenvolvidas algumas das principais correntes que disputarão a hegemonia do pensamento urbanístico ao longo do século XX: os campos 
Os formuladores desse "pré-urbanismo progressista", como Owen, Fourier e Proudhon, centravam suas críticas a respeito da cidade e sociedade industriais, principalmente, na "alienação" a que estava sujeito o trabalhador sob as condições de trabalho e vida a que estava submetido. Esses formuladores partem do princípio da definição do ser humano como um tipo-ideal, despido de especificidades, contingências ou diferenças em relação a tempo e lugar, gênero ou origem étnica. Assim, eles crêem nas possibilidades trazidas pela Revolução Industrial como instrumental para o bem-estar de toda a humanidade. Para tanto, impuseram-se a necessidade de conhecer e identificar as necessidades desse "tipo-ideal" humano, estabelecidas por meio de estudos científicos rigorosos, objetivando estabelecer as condições do bem-estar coletivo ${ }^{7}$.

A concepção de espaço para os representantes do "pré-urbanismo de modelo progressista" é, de certa forma, uma negação da cidade ocidental tradicional, construtivamente densa e em profundo contraste com o campo; suas propostas objetivam superar essa dicotomia com a proposta da cidade-campo, como justaposição de unidades atomizadas, autônomas e justapostas no espaço, isolados umas das outras por amplas áreas verdes e abertas. Para estes, as funções urbanas seriam dispostas e alocadas no território de acordo com precisas e rigorosas classificações, separando-se precisamente as funções; preconizavam uma estética funcional, rompendo com os esteticismos do passado e sendo reflexo dos novos tempos, além de propor modelos construtivos específicos para cada função urbana, com ênfase especial à habitação, ao local da moradia, sem haver, contudo, uma unidade a respeito da forma ideal a ser adotada, se unifamiliar ou plurifamiliar $^{8}$.

Robert Owen, enriquecido com a atividade de industrial da fiação, foi o primeiro e mais importante dentre os reformistas utópicos, tendo desenvolvido propostas bastante avançadas e complexas para a melhoria das condições de vida e trabalho dos operários de sua fábrica. A concepção de espaço formulada por Owen previa uma radical reformulação

de análise a partir dos quais são formulados modelos alternativos à cidade industrial - o modelo "reformista" e o modelo "culturalista"; além desses dois, ela também identifica os campos da crítica sem formulação de modelo, representados pela crítica "marxista" e pelo campo "anti-urbano americano".

${ }^{7}$ Cf. CHOAY, Françoise. Op. Cit., 1997, p. 8-11.

8 O outro campo definido por Choay, aquele de "modelo culturalista", diversamente do de "modelo progressista", não parte do indivíduo como base de suas proposições, mas do agrupamento humano, com uma perspectiva saudosista da cidade antiga, que crêem ter sido destruída pela Revolução Industrial. Isto os leva à defesa do resgate da cidade tradicional, densa, "circunscrita no interior de limites precisos. Enquanto fenômeno cultural, ela deve formar um contraste sem ambigüidade com a natureza" (p. 13). Ambos os campos, porém, enxergam a cidade em termos de modelo, não como processo ou problema, mas como um objeto reprodutível. Cf. CHOAY, Françoise. Op. Cit., 1997, p. 114. 
do urbano, em que se borravam as distinções entre este e o ambiente rural, propondo uma cidade ideal, produtiva, e dotada de todos os serviços necessários.

Esta cidade ideal deveria ter entre 300 e 2.000 habitantes, para os quais se previa uma série de equipamentos coletivos. A cidade seria circundada por uma área agricultável de cerca de um acre por pessoa, uma vez que todos os moradores se dedicariam ao trabalho agrícola e, também, ao industrial, ao passo que os excedentes produzidos poderiam ser livremente trocados pela comunidade. Esta cidade seria implantada nos moldes de um empreendimento privado e seus moradores obedeceriam às leis gerais do país. Contudo, para Owen, esta comunidade não teria necessidade nem de tribunais nem de prisões, uma vez que a harmonia social obtida com sua implantação eliminaria os conflitos entre classes e entre indivíduos. Não tendo conseguido realizar essa experiência na Inglaterra deu início, com alguns seus seguidores, à implantação da cidade de New Harmony, no ano de 1825, nos Estados Unidos, onde assiste ao seu fracasso e sua própria ruína econômica ${ }^{9}$.

Na França, tomando como modelo físico o Palácio de Versalhes, Fourier propõe, já nas primeiras décadas do século XIX, seu modelo de sociedade "não-repressiva" que deveria ser predominantemente agrícola, suplementada por uma manufatura leve ${ }^{10}$. Seus habitantes residiriam em equipamentos coletivos, à semelhança de um grande hotel, reservando-se o térreo para os idosos, o mezanino para as crianças e os andares elevados para os adultos, bem como equipamentos e serviços coletivos ${ }^{11}$.

Alguns anos depois, inspirado nas idéias de Fourier, o empresário Jean-Baptiste Godin implantou, entre 1859 e 1870, seu Familistério na cidade de Guise, composto de três blocos residenciais, creche, jardim da infância, teatro, escolas, banhos públicos e lavanderia. Diversamente do Falanstério de Fourier, aqui o núcleo familiar era a base para a definição do programa da unidade habitacional ${ }^{12}$.

A visão idílica e utópica acerca da eliminação dos conflitos, da violência, por meio da transformação social conseguida com a remodelação "projetada" do espaço e, correlatamente, das relações sociais, será a chave da urbanística moderna. Esse homem tipo-ideal para o qual os "pré-urbanistas progressistas" elaboraram suas propostas será incorporado pelo urbanismo moderno e exercerá influência fundamental na concepção da habitação proletária ao longo de grande parte do século $\mathrm{XX}$; o homem tipo-ideal, para o

\footnotetext{
${ }^{9}$ Cf. BENEVOLO, Leonardo. Op. Cit., 2006, p. 176.

${ }^{10}$ Cf. FRAMPTON, Kenneth. Op. Cit., 2003, p. 15.

${ }^{11}$ Cf. BENEVOLO, Leonardo. Op. Cit., 2006, p. 178.

${ }^{12}$ Cf. FRAMPTON, Kenneth. Op. Cit., 2003, p. 16.
} 
qual se projeta a nova moradia, base da nova cidade, é o gerador de seu desenho e, dialética e paradoxalmente, deve emergir desse espaço como um ser humano completamente novo, transformado, uma vez que suas demandas mais prementes seriam todas racionalmente equacionadas e atendidas. Qualquer necessidade que escapasse ao esquema racional totalizante desse ideário seria um desvio, a ser ignorado ou eliminado.

Nos últimos anos do século XIX e início do século $X X$, CHOAY identifica a passagem desse "pré-urbanismo", desenvolvido por generalistas, de propostas marcadamente utópicas, para o que ela define como o nascimento do urbanismo como o entendemos atualmente, como disciplina prática e instrumental, tarefa de especialistas, notadamente arquitetos ${ }^{13}$.

\subsection{O Urbanismo Moderno}

Em 1898 Ebenezer Howard lança seu livro "Cidades-Jardins do Amanhã", em que apresenta uma proposta de síntese entre o campo e a cidade, entre o ambiente rural e o urbano. Howard, que não era arquiteto, propõe uma cidade de tamanho limitado, absolutamente auto-suficiente e distante das mazelas que "infestavam" os grandes centros urbanos. Por isso busca conjugar os ideais da autonomia e comunitarismo presentes no socialismo utópico de princípios do século com a cultura e a moral vitoriana, com seu gosto pelas residências isoladas em meio ao verde, ao sol e à "salubridade".

Ele não chega a definir um desenho concreto para seu modelo de cidade, afirmando mesmo que seus esquemas são apenas indicativos, devendo ser adaptados para cada caso concreto. O próprio Howard toma parte em duas sociedades a fim de promover a implantação das primeiras cidades-jardim: Letchworth (1903) e Welwyn (1919). Da concepção inicial de que um sexto da área total do empreendimento seria destinado às residências e à indústria, e o restante à agricultura, vai-se alterando progressivamente com a redução da área rural. Mesmo se mostrando viável e factível, a cidade-jardim não consegue alcançar a desejada auto-suficiência e autonomia preconizada por Howard. Trinta anos depois de implantada Letchworth não havia atingido metade dos 35.000 habitantes esperados. Welwyn teve maior sucesso, atingindo 35.000 habitantes antes da Segunda Guerra Mundial. Isso se deveu, fundamentalmente, ao fato de apresentar maior proximidade com Londres e à redução da área destinada à agricultura, o que lhe conferiu características mais de subúrbio que de cidade autônoma ${ }^{14}$.

\footnotetext{
${ }^{13}$ Cf. CHOAY, Françoise. Op. Cit., 1997, p. 18.

${ }^{14}$ Cf. BENEVOLO, Leonardo. Op. Cit., 2006, p. 358.
} 
Alguns autores consideram a Cidade-jardim como "o primeiro modelo científico de planejamento urbano em uma escala territorial”" ${ }^{\prime 1}$, desvencilhando-se da carga utópica presente nos enunciados de Owen em prol de uma perspectiva realizável. Ao mesmo tempo, porém, procedeu-se a um reducionismo nas pretensões comunitárias presentes nos socialistas utópicos, ficando limitada a contribuição do conceito de cidade-jardim aos seus aspectos pitorescos e paisagísticos, sob um ideal claramente anti-urbano. A própria concepção da cidade-jardim como ente auto-suficiente e autônomo, provendo aos seus moradores todos os serviços, trabalho e lazer de que necessitavam, sem a necessidade de contato com as grandes metrópoles e sem alternativas fora de seu roteiro pré-concebido, gerou críticas como a de JACOBS, para quem as cidades-jardim eram "cidades realmente muito agradáveis se os moradores fossem dóceis, não tivessem projetos de vida próprios e não se incomodassem em levar a vida em meio a pessoas sem projetos de vida próprios"16.

As propostas e experiências estabelecidas pela Cidade-Jardim de Howard representam algumas das mais importantes e duradouras idéias a influenciar o urbanismo ao longo do século $\mathrm{XX}$, sendo a base conceitual da concepção desde bairros de alta renda na cidade de São Paulo (os Jardins), até as novas cidades inglesas do pós-segunda guerra, passando pelas Siedlungen de Frankfurt da década de 1920.

Já o novo "urbanismo progressista" identifica na era industrial uma ruptura histórica radical, enxergando como obsoletas as estruturas e ensinamentos urbanísticos do passado. Para estes, "a grande cidade do século $X X$ é anacrônica porque não é contemporânea verdadeira nem do automóvel, nem das telas de Mondrian"17.

Herdeiro dos pensadores progressistas do período anterior, os urbanistas progressistas crêem, assim como aqueles, na existência de um "tipo-ideal" de ser humano, para o qual elaboram seus modelos, numa busca obsessiva pela saúde e pela higiene, pelo sol e pelo verde. As funções dentro da cidade deveriam ser claramente definidas e separadas, resultando num espaço rígido e altamente fragmentado, definido por um especialista: o urbanista. Como conseqüência, a cidade proposta a partir desses conceitos fragmentadores e atomizantes, paradoxalmente, apresenta um caráter fortemente antiurbano. A lógica inerente a esse conjunto de idéias estava diretamente vinculada à

\footnotetext{
${ }^{15}$ TAFURI, Manfredo \& DAL CO, Francesco. Modern Architecture. New York: Harry Abrams Publishers, 1979, p.33 apud SLOMIANSKY, Adriana Paula. Cidade Tiradentes: a abordagem do poder público na construção da cidade - conjuntos habitacionais de interesse social da COHAB-SP. São Paulo: tese de doutoramento apresentada à FAUUSP: FAUUSP, 2002, p. 18.

${ }^{16}$ JACOBS, Jane. Morte e vida de grandes cidades. São Paulo: Martins Fontes, 2000. p. 17.

${ }^{17}$ CHOAY, Françoise. Op. Cit., 1997, p. 20.
} 
necessidade de se eliminar os obstáculos que se impunham à expansão e consolidação do modo de produção capitalista no coração da cidade antiga, a qual se mostrava incapaz de se adequar às demandas tanto dos operários (por moradia), quanto dos capitalistas (por terra, infra-estrutura e acessibilidade); para superá-los, fazia-se necessária "uma ordem rigorosa que responda a um novo tipo de eficácia, o da atividade produtora"18.

Ao redor do mundo verificaram-se, ao longo das primeiras décadas do século $X X$, importantes mudanças sociais e técnicas que acarretaram em transformações significativas do modo como se encarava a questão do atendimento das carências habitacionais das camadas proletárias.

A revolução de outubro de 1917 levou o Partido Bolchevique a exercer o poder na Rússia em nome do proletariado, abrindo as portas para a constituição de uma sociedade nova, construída por homens novos. Os governos socialistas e social-democratas na Áustria e na Alemanha no período pós-Primeira Guerra empreenderam ações efetivas para a melhoria das condições de vida da classe trabalhadora, com a construção dos Höfe e das Siedlungen, respectivamente. Encontrava-se em gestação o modernismo em arquitetura, buscando respostas às novas demandas sociais trazidas no bojo da industrialização e urbanização da Europa.

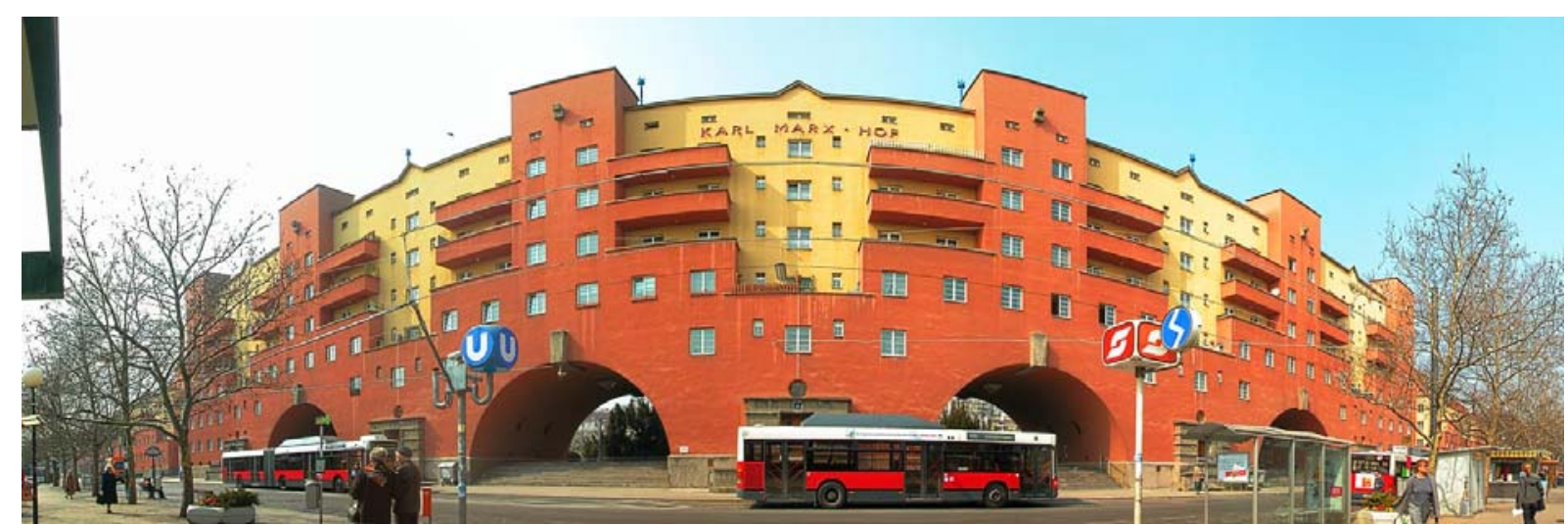

O Karl Marx Höf é um dos mais emblemáticos conjuntos habitacionais produzidos sob a administração socialista de Viena, em fins da década de 1920. Os Höfe vienenses foram importantes focos de resistência proletária ao avanço nazi-fascista. O Karl Marx Höf, com suas 1.400 habitações, foi o último a cair in KOPP, Anatole. Quando o moderno não era um estilo e sim uma causa. São Paulo: Nobel, 1990, p. 45. Imagem acessada em 30 de agosto de 2007 do sítio http://www.panos.at/wien5/200303281136_PAN-KarlMarxHofc!(x525)s.jpg

O conceito de "Moderno" na produção arquitetônica aqui utilizado é aquele usado por KOPP ${ }^{19}$ em sua análise da incipiente produção arquitetônica européia e também, mas menos significativa, norte-americana, do período entre-guerras, entendido esse conceito como a introdução das questões e demandas sociais na reflexão e produção arquitetônica

\footnotetext{
${ }^{18}$ CHOAY, Françoise. Op. Cit., 1997, p. 22.

${ }^{19}$ KOPP, Anatole. Quando o moderno não era um estilo e sim uma causa. São Paulo: Nobel, 1990.
} 
e urbanística do período. Essa reflexão arquitetônica estaria imbuída de compromissos políticos progressistas, com vistas à constituição de uma sociedade marcada pela emancipação da classe trabalhadora. Esse conceito contrapõe-se àquele do modernismo enquanto transformações de ordem predominantemente formal e técnica.

NAKANO analisa as contradições presentes desde o início na própria lógica do projeto moderno, na existência de uma simbiose entre o "projeto modernista" e o desenvolvimento e a reprodução do capital industrial, a partir da perspectiva teórica elaborada por Otília e Paulo Arantes e utilizada por ele, segundo os quais

a mesma lógica 'sistêmica' de modernização (capitalista) governa o elementarismo programático das formas simples, do produto em série, estandardizado, das fachadas homogêneas, das aberturas padronizadas, dos módulos, da moradia mínima, dos modelos, tipos e invariantes, que se harmonizam (por assim dizer) no novo panorama urbano. Obedecendo aos princípios da linha de montagem, estas células que se ordenam no tecido urbano vão se ajustando segundo leis e ritmos do consumo de massa, na acepção literal e perversa do termo. ${ }^{20}$

O conjunto do ideário modernista vai encontrar forte penetração no Brasil da primeira metade do século XX e vai ao encontro do ambiente de "modernização" da sociedade brasileira e expansão do capitalismo periférico nacional; o contexto político do Estado Novo também favorece a concepção modernista "corbusiana" e sua idéia de "autoridade".

\subsection{A Habitação no Centro da Questão Urbana}

Nesses primórdios do modernismo, passou-se de uma fase de produção arquitetônica de realizações únicas e excepcionais para a arquitetura aplicada às soluções das necessidades coletivas, representadas pelo conjunto dos trabalhadores.

Algumas das primeiras experiências de produção em escala de habitação popular podem ser encontradas na Alemanha, no imediato pós-Primeira Guerra Mundial. A grave crise econômica associada à rápida urbanização por que passava o país agravou sobremaneira as precárias condições habitacionais da classe trabalhadora alemã.

Surgiram preocupações em dar aos habitantes dos cortiços industriais alemães condições de vida decentes. As grandes Siedlungen construídas entre 1925 e 1933 não se compunham somente pela habitação, mas por um grande número de equipamentos

20 ARANTES, Otília e ARANTES, Paulo. Um ponto cego no projeto moderno de Jürgen Habermas Arquitetura e dimensão estética depois das vanguardas. São Paulo: Brasiliense, 1997, p. 70 apud NAKANO, Kazuo. 4 COHABs da Zona Leste de São Paulo: território, poder e segregação. Dissertação de Mestrado apresentada à FAUUSP. São Paulo: FAUUSP, 2002, p. 76. 
coletivos, assim como os conjuntos soviéticos da mesma época. O contexto político dos governos social-democratas proporcionou a alguns dos primeiros arquitetos modernos, como Hannes Meyer e Ernst May, a possibilidade de pôr em prática as mais avançadas discussões a respeito da moradia proletária. As primeiras experiências em torno das Siedlungen agrupavam centenas, até milhares de habitações populares em torno de infraestruturas sociais, culturais e técnicas, sendo tentativas de resolver o problema da produção em massa através do uso de técnicas ainda novas, aumentando a produtividade, reduzindo prazos e custos e implantando equipamentos coletivos ${ }^{21}$.

Após a Revolução de Outubro de 1917, a discussão em torno de uma nova formulação arquitetônica e urbanística, representativa da nova sociedade socialista teve início. Os arquitetos soviéticos autodenominados construtivistas tinham como objetivo criar uma nova arquitetura que fosse ao mesmo tempo a imagem da futura sociedade e o "cadinho no qual essa sociedade nasceria e se desenvolveria"22. As propostas desses arquitetos se antecipavam à existência real de uma demanda habitacional proletária na Rússia de então, eminentemente rural.

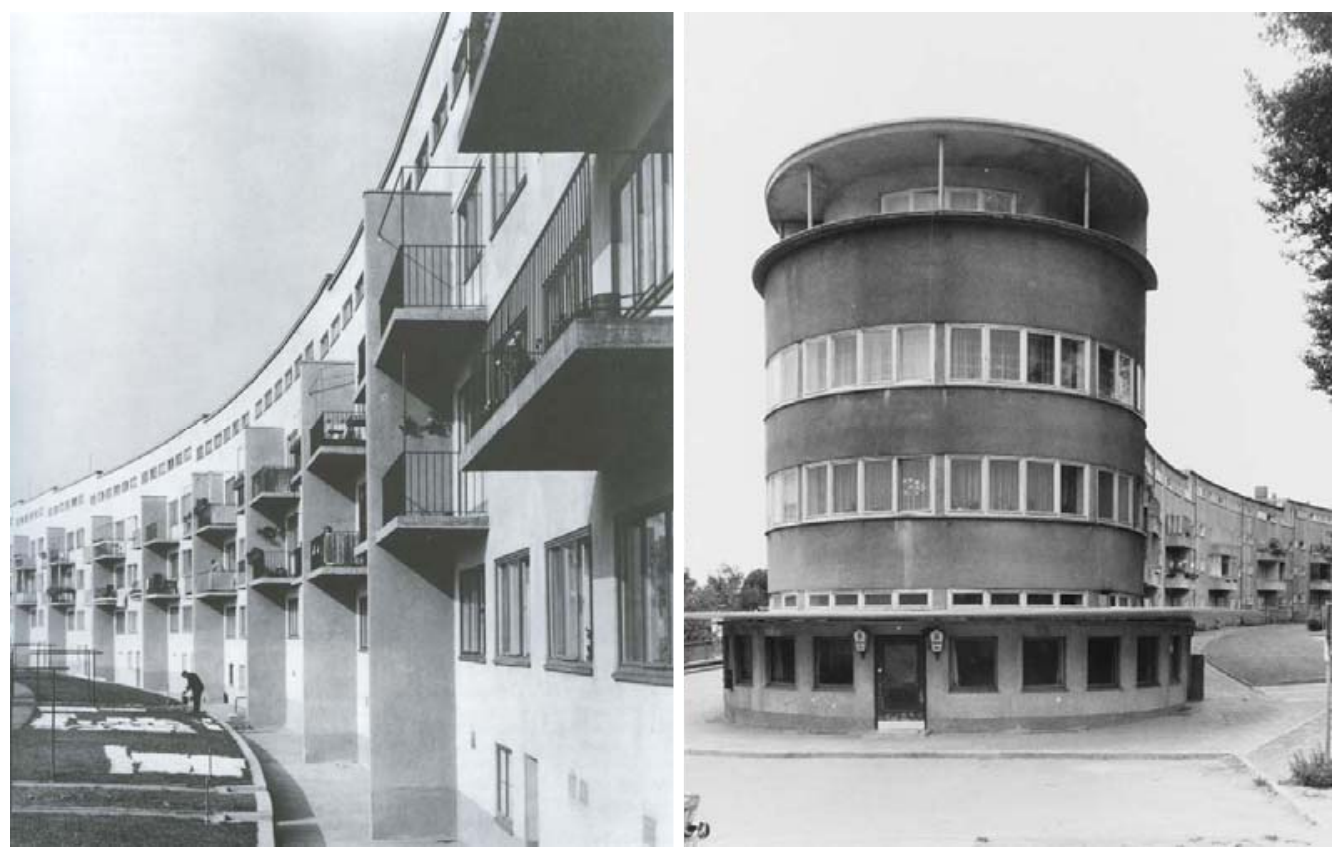

Vista lateral e frontal da Siedlung Römerstadt, em Frankfurt am Main, Alemanha, projeto de Ernst May desenvolvido entre 1927-28, quando era arquiteto-chefe da municipalidade. Imagem da esquerda in GÖSSEL, Peter e LEUTHÄUSER, Gabriele. Arquitectura no Século XX. Colônia: Taschen, 1996, p. 161. Imagem da direita acessada de http://www.artandarchitecture.org.uk/images/conway/02695776.html.em 14 de abril de 2008.

As propostas dos construtivistas soviéticos para a habitação proletária não se restringiam ao atendimento de uma demanda, mas sim à construção de um novo modo de

\footnotetext{
${ }^{21}$ Cf. KOPP, Anatole. Op. Cit., 1990, p. 18.

${ }^{22}$ KOPP, Anatole. Op. Cit., 1990, p. 75.
} 
vida, privilegiando o coletivo em oposição ao modo de vida pequeno-burguês, individualista e mesquinho ${ }^{23}$.

Nesse período são recorrentes as menções ao "homem novo", à "nova vida" e à "cidade do futuro". As novas formas de habitação, modificando o ambiente, modificariam o ser humano, uma vez que o homem seria reflexo de seu habitat. Esse ideário sobre o poder transformador do ambiente sobre o homem era especialmente significativo na Alemanha, onde influenciou grande parte dos primeiros arquitetos modernistas ${ }^{24}$.

Essa nova arquitetura baseava-se na padronização e na repetição enquanto valores de racionalização da sociedade, de modo a garantir espaços iguais a todos, como forma de promover a igualdade entre os homens ${ }^{25}$, sendo realizada por meio da ação do Estado, substituindo o laissez faire vigente até então por uma atuação decisiva da estrutura governamental.

Essas preocupações levaram a que o Segundo CIAM - Congresso Internacional de Arquitetura Moderna, realizado em Frankfurt (cidade em que, aliás, foram produzidas algumas das mais significativas Siedlungen pela municipalidade social-democrata local) tenha como tema central de discussão "a questão da habitação para os setores de renda mínima, discutindo-se a necessidade de atender à crescente carência de moradias para os operários"26. Este Congresso inseriu-se num contexto de hegemonia das idéias e experiências desenvolvidas pelos socialistas alemães, como Hannes Meyer e Ernst May, período que engloba os três primeiros $\mathrm{CIAMs}^{27}$.

A partir do IV - CIAM, realizado em 1933 a bordo do navio S. S. Patris, entre Marselha e Atenas, passou-se ao predomínio da temática do planejamento urbano sob o domínio da personalidade de Le Corbusier ${ }^{28}$. Neste CIAM são realizados estudos de caso comparativos entre 34 cidades, a partir dos quais é formulado um documento voltado ao planejamento, propondo um rígido zoneamento das funções internas à cidade e a

${ }^{23}$ Cf. KOPP, Anatole. Op. Cit., 1990, p. 80 e 86.

24 Estes eram herdeiros das idéias do movimento reformador alemão, sobretudo no tocante à idéia a respeito do poder transformador do ambiente sobre o homem. Cf. KOPP, Anatole. Op. Cit., 1990, p. 39.

${ }^{25}$ Cf. KOPP, Anatole. Op. Cit., 1990, p. 51.

${ }^{26}$ BONDUKI, Nabil. Op. Cit., 1998, p. 137.

27 Segundo periodização desenvolvida por Kenneth Frampton: La Sarraz - 1928, e suas discussões acerca da necessidade de padronização e industrialização planejada como forma de aumentar a produção; Frankfurt - 1929, onde se deu o debate acerca do tamanho mínimo da moradia (Existenzminimum) e Bruxelas - 1930, onde se discutiu qual a altura ideal para as edificações nos novos bairros e cidades modernos. Cf. FRAMPTON, Kenneth. Op. Cit., 2003, p. 328-9.

${ }^{28}$ Esta fase de predomínio de Le Corbusier ainda se estenderá pelo V CIAM (Paris, 1937) até o sexto congresso (Bridgwater, Inglaterra, 1947), quando o ideário liberal triunfa sobre o materialismo vigente até o momento. Cf. FRAMPTON, Kenneth. Op. Cit., 2003, p. 328-9. 
edificação de edifícios isolados em meio ao verde e desvinculados da malha viária da cidade tradicional. Este documento é publicado cerca de dez anos depois sob o nome de Carta de Atenas e será o guia de orientação a inúmeras propostas e formulações urbanas dali em diante, ao definir as quatro funções da cidade: morar, trabalhar, recrear-se (no tempo livre) e circular ${ }^{29}$.

Nesse contexto se dá uma das contribuições mais ambíguas e contraditórias, porém decisiva, à evolução da Arquitetura Moderna, realizada por Le Corbusier. Detentor de vasta obra em defesa da "revolução" propiciada pelas novas técnicas para a constituição de uma sociedade nova, Le Corbusier depositava suas esperanças na condução desse processo de superação da sociedade antiga a um Estado forte, à "autoridade", a fim de se evitar o risco de uma "revolução" social. O caráter autoritário de seu programa fica evidente em um de seus principais textos:

A maquinaria da sociedade, profundamente desengrenada, oscila entre uma melhora, de importância histórica, e uma catástrofe. O instinto primordial de todos os seres humanos é garantir um abrigo. As diferentes classes de trabalhadores de nossos dias não têm mais moradias adaptadas às suas necessidades, e o mesmo se pode dizer acerca do artesão ou do intelectual. O que se encontra na raiz da inquietação social de hoje é uma questão de construção: arquitetura ou revolução. ${ }^{30}$

Uma de suas propostas que mais impacto teve na produção arquitetônica moderna foi a Ville Radieuse, elaborada entre 1929 e 1930, que consistia numa composição edificada em rédent de moradias alinhadas, com espaços reduzidos ao mínimo a fim de conseguir uma habitação de menor custo, insulando-se em blocos com 11 andares de altura, 400 metros de comprimento e a 200 metros de distância do edifício em frente. Os prédios se ergueriam do solo sobre pilotis, abrindo-se o espaço do térreo como um parque ${ }^{31}$. A unidade residencial seria o ponto de partida para todo o desenho da nova cidade; as funções urbanas seriam distribuídas segundo um zoneamento estrito, disposto em faixas de zonas paralelas.

\footnotetext{
${ }^{29}$ Interessante notar a qualificação da circulação como uma função em si, e não como suporte ou meio às demais funções. Paradoxalmente, a proeminência do automóvel na cidade contemporânea acabou hipertrofiando esta função, contribuindo para o esgarçamento do tecido urbano, o que o levou a se tornar um dos principais condicionantes das demais funções, configurando-se a mobilidade e a acessibilidade alguns dos mais importantes atributos da localização e fator preponderante na definição do valor da terra urbana, conforme análise de Flávio Villaça. VILLAÇA, Flávio. Op. Cit., 1998.
}

${ }^{30}$ LE CORBUSIER. Vers une Architecture. 1923 apud FRAMPTON, Kenneth. Op. Cit., 2003, p. 215.

${ }^{31}$ Cf. BENEVOLO, Leonardo. Op. Cit., 2006, p. 500. 


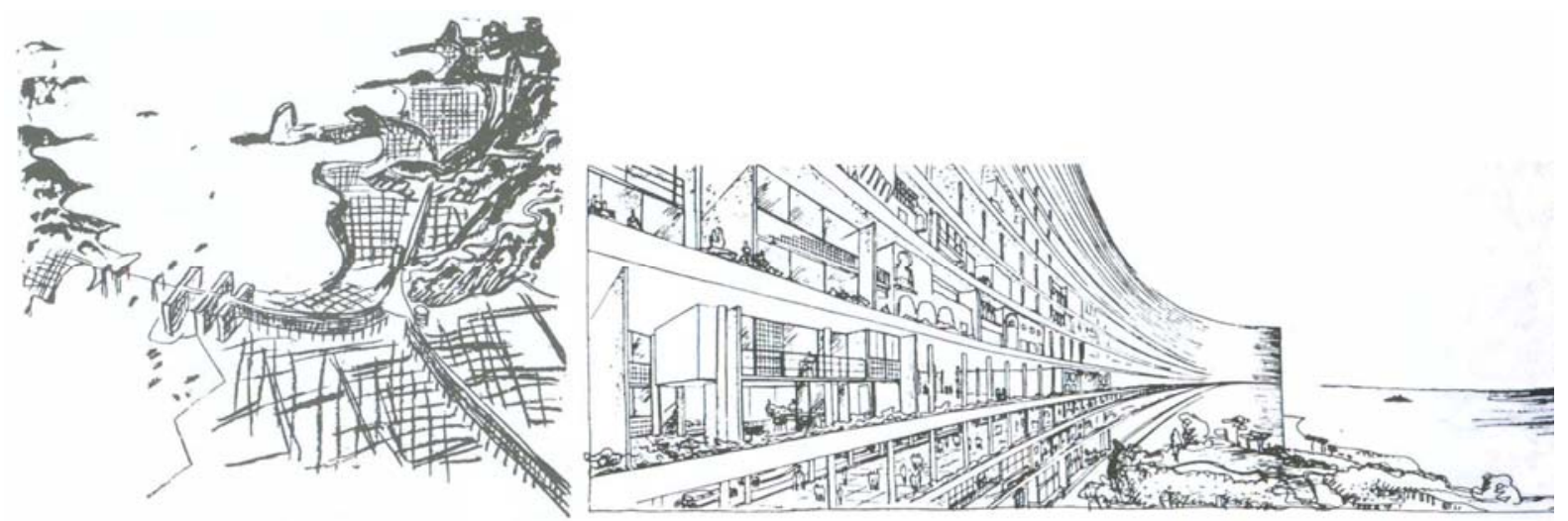

À esquerda, proposta de Le Corbusier para o Rio de Janeiro, de 1930, onde propõe uma "cidade-viaduto" ao longo da costa, sobrepondo uma auto-pista ao complexo residencial. À direita, proposta para a cidade de Argel, do mesmo ano, e com solução tipológica semelhante. Imagem extraída de FRAMPTON, Kenneth. Op. Cit., 2003, p. 218.

Le Corbusier desenvolveu o conceito da Ville Radieuse em seus projetos para o Rio de Janeiro e Argel (1930) e, mais tarde, o materializou em suas Unité d'Habitation, conjunto que agregava além das unidades habitacionais uma ampla gama de serviços e equipamentos e que teve a oportunidade de implantar, primeiramente em Marselha, em 1947 e, posteriormente, outros na França e na Alemanha. A influência representada pelo conceito da Ville Radieuse foi largamente difundido durante a reconstrução da Europa no pós-Segunda Guerra, revelando-se particularmente desastroso como modelo para os grands ensembles, os grandes conjuntos habitacionais implantados na França entre as décadas de 1950 e 1970. Esse modelo também influenciou largamente a concepção das cidades de Chandigarh e Brasília, ambas projetadas na década de $1950^{32}$.

\subsection{A Reconstrução Européia no Pós-Guerra}

Após a Segunda Guerra Mundial extensas áreas das cidades de países envolvidos na conflagração encontravam-se destruídas, grande parte disso representado pelas moradias danificadas ou eliminadas pelos confrontos que as tiveram como palco. Deve-se ter em conta, ainda, que a questão da demanda habitacional por parte das camadas de mais baixa renda seguia sem resolução, estas vindo a se juntar aos vastos contingentes sem moradia que surgiram após o término do conflito.

Esse cenário de devastação social e econômica demandava a reorganização completa do quadro político, com a redefinição do papel e das funções do Estado, como organizador dos esforços de reconstrução, promovendo um novo pacto social. Nesse contexto são incorporadas as idéias do economista inglês John Maynard Keynes pelos partidos social-democratas europeus, servindo de base ideológica ao intervencionismo

${ }^{32}$ Cf. FRAMPTON, Kenneth. Op. Cit., 2003, p. 219-20. 
estatal do segundo pós-guerra em contraposição ao liberalismo vigente até então. O keynesianismo foi "o responsável por conferir organicidade teórica e vigor ideológico às reformas sociais a serem efetivadas pelos diversos Estados nacionais, num contexto internacional marcado pela perspectiva de reconstrução econômica e política"33.

A partir deste arcabouço ideológico passou a se dar uma nova forma de atuação por parte do Estado na regulação e produção do espaço urbano, participando ativamente da reestruturação do território e sendo o mais importante ator na reconstrução habitacional, sob uma perspectiva de expansão de um mercado de consumo de massa e da universalização dos direitos sociais, no contexto de consolidação do Estado de Bem-Estar Social.

Nesse momento a atuação estatal na produção de moradias às camadas de baixa renda se deu por meio da promoção de Habitação de Interesse Social através de instituições públicas ou entidades sem fins lucrativos, na produção direta de unidades de baixo custo; pela regulação do mercado habitacional, estabelecendo controle dos valores imobiliários; pelo estímulo à produção e ao consumo, oferecendo financiamentos às duas pontas do mercado imobiliário habitacional; e pela promoção de pesquisa e desenvolvimento voltados à industrialização da construção, com o intuito de baratear o processo de produção de novas unidades. Coube ao Estado assumir esses desafios - dos quais vinha se esquivando desde o século XIX - pela constatação de que o setor privado, regido apenas pelas leis do mercado, não tinha condições de atender a essa demanda, pois sua capacidade produtiva estava desarticulada em função da Segunda Guerra Mundial $^{34}$.

Essa limitação do setor privado precisa ser entendida como estrutural, tendo sido originada, entre outros fatores, pela baixa velocidade de rotação do capital no setor, o que o torna pouco atrativo aos capitais privados; pela subordinação do processo de produção à base fundiária existente; além das características intrínsecas ao processo de trabalho no setor, que dificultam o aumento da produtividade e redução dos custos de produção. A sociologia urbana francesa, após a década de 1960, identificou nessa atuação do Estado, ainda, uma forma de garantir a reprodução ampliada da força-de-trabalho, necessária ao processo de acumulação, ao retirar o custo da moradia das pressões por melhorias

\footnotetext{
${ }^{33}$ FONSECA, Francisco. O Consenso Forjado. São Paulo: Hucitec, 2005, p. 52. Segundo a leitura deste autor, para Keynes, a ação política do Estado deveria se basear em um programa estruturado a partir dos seguintes pontos: intervenção do Estado em termos macroeconômicos; apoio aos sindicatos; e incorporação do tema da igualdade na acumulação.
}

${ }^{34}$ Cf. FARAH, Marta. Op. Cit., 1990, p. 12. 
salariais $^{35}$. Esse momento de embate ideológico e econômico entre o capitalismo ocidental e o socialismo real soviético forçava o Estado a intervir na promoção de melhorias sociais, do qual a moradia era uma das reivindicações mais importantes.

Esse esforço de reconstrução pôs em prática em larga escala o ideário urbanístico modernista preconizado pelos CIAMs; ideário este que ainda não havia realizado mais que experiências pontuais - caso das Siedungen alemãs - ou ultrapassado o nível de esquemas conceituais razoavelmente genéricos, nunca testados efetivamente na prática no enfrentamento aos problemas da cidade industrial na escala em que agora se pretendia. Ainda assim, a arquitetura moderna e a urbanística dos CIAMs impuseram-se como modelo na reconstrução e produção de novos espaços urbanos nas cidades arrasadas pela guerra ${ }^{36}$.

A este momento a ideologia da arquitetura moderna já havia entrado em crise, levando à superação e abandono das utopias do "Neue Welt", o Mundo Novo, onde seriam resolvidas as contradições da cidade e da sociedade por meio do enfrentamento dos problemas urbanos através do projeto arquitetônico. Nas palavras de TAFURI,

a arquitectura como ideologia do Plano é subvertida pela realidade do plano, uma vez que, superado o nível da utopia, este se torna mecanismo operante.

A crise da arquitetura moderna começa no preciso momento em que o seu destinatário natural - o grande capital industrial - supera sua ideologia de fundo, pondo de parte as superestruturas ${ }^{37}$.

Diferentemente da "causa" que KOPP identificava nos primeiros modernistas, relativas à transformação social e à constituição de um Homem Novo, para o qual a contribuição da arquitetura seria fundamental, neste novo momento a arquitetura moderna abandona suas utopias libertárias e torna-se elemento fundamental na reorganização da produção e do consumo relativos à reconstrução do pós-guerra.

$\mathrm{Na}$ Inglaterra a reconstrução urbana e habitacional teve início mais cedo. Já em 1944 foi designada uma Comissão Real com a função de elaborar um diagnóstico e propostas para a reorganização do território inglês tanto em relação à ocupação humana quanto das atividades produtivas ${ }^{38}$. O governo trabalhista eleito em 1945 deu

${ }^{35}$ Cf. FARAH, Marta. Op. Cit., 1990, p. 13.

${ }^{36}$ Cf. LAMAS, José Manuel Ressano Garcia. Morfologia Urbana e Desenho da Cidade. Porto: Fundação Calouste Gulbenkian: Fundação para a Ciência e Tecnologia, 2007, p. 362.

37 TAFURI, Manfredo. Projecto e Utopia: arquitectura e desenvolvimento do capitalismo. Lisboa: Presença, 1985, p. 92.

${ }^{38}$ Esse plano para a reconstrução de Londres qualifica a região da capital inglesa em três zonas distintas: a Zona Interna, correspondendo ao Condado de Londres, com cerca de cinco milhões de habitantes distribuídos em 55.000 hectares, para a qual se propunha a diminuição em cerca de 400.000 
prosseguimento à implementação desse programa, aprovando uma lei em 1946 que viabilizou a realização de cidades novas. São propostas 22 novas cidades, 14 na Zona Externa de Londres e 8 em outras regiões da Inglaterra, com um programa, e até mesmo no tamanho previsto (em torno de 40.000 habitantes), inspirado nas cidades-jardim do início do século XX. Até o ano de 1973, 25 anos depois das primeiras experiências com essa proposta, as new towns inglesas, implantadas ou ainda em construção, previam abrigar 750.000 pessoas nessas novas estruturas urbanas ${ }^{39}$. A partir dos anos 1950 essas cidades imersas no verde foram muito criticadas pela dispersão que apresentavam. Foram então propostas cidades mais compactas e mais lógicas no agrupamento e distribuição das funções, caso da cidade nova de Milton Keynes, no meio do caminho entre Londres e Birmingham, a 80 quilômetros daquela, e que se esperava atingir uma população de 250.000 habitantes no ano $2000^{40}$. Essas experiências de construção de novas cidades com vistas à reorganização completa do território quanto à distribuição da população e das atividades produtivas foi excepcional, mesmo na Inglaterra, não significando, como desejavam os arquitetos modernistas do início do século, uma reformulação completa da experiência urbana da sociedade industrial ${ }^{41}$.

$\mathrm{Na}$ Inglaterra formou-se uma complexa e poderosa "máquina burocrática de planejamento urbano e arquitetônico", sem paralelo em nenhum outro país da Europa Ocidental, capacitando e tornando possível o enfrentamento dos problemas urbanos a partir de um bem estruturado poder público. Esses órgãos estatais chegaram a empregar aproximadamente metade dos arquitetos da Grã-Bretanha, sendo responsáveis por quase $45 \%$ de toda a produção imobiliária anual nesse período ${ }^{42}$.

A Espanha, ainda que não tivesse tomado parte na Segunda Grande Guerra, enfrentava problemas semelhantes referentes ao seu próprio conflito, a Guerra Civil terminada em 1939. Cerca de 250 mil moradias foram destruídas, além de igual número de unidades danificadas, o que representava aproximadamente $10 \%$ do parque habitacional

habitantes; a Zona Suburbana, no entorno do Condado de Londres, com cerca de três milhões de habitantes em 58.000 hectares, onde se previa a manutenção da mesma; e a Zona Externa, que incluía o cinturão verde mais a área envoltória, num raio de aproximadamente 60 a 80 quilômetros do centro, onde se deveriam implantar cidades novas e expandir as pequenas existentes. Cf. BENEVOLO, Leonardo. Op. Cit., 2007, p. 679.

${ }^{39}$ Department of the Environment, Scottish Development Department, Welsh Office and Central Office of Information. The New Towns. Londres: Curwen Press, 1973, p. 5.

${ }^{40}$ Department of the Environment, Scottish Development Department, Welsh Office and Central Office of Information. Op. Cit., 1973, p. 20.

${ }^{41}$ Cf. BENEVOLO, Leonardo. Op. Cit., 2007, p. 679-685.

42 Cf. MONTANER, Josep Maria. Depois do Movimento Moderno: Arquitetura da Segunda Metade do Século XX. Barcelona: Gustavo Gili, 2001, p. 35. 
espanhol. Além disso, a migração de camponeses para as cidades em busca de melhores condições de vida produziu o deslocamento de cerca de 800.000 pessoas ao longo da década de 1940. No entanto, ao contrário dos demais países da Europa Ocidental recém saídos da Guerra - e que viviam um intenso e acelerado crescimento econômico que contribuiu para o enfrentamento da carência habitacional - o regime franquista promoveu um grande fechamento e isolamento do país, arrastando-o a uma crise econômica prolongada $^{43}$.

Logo após o fim da Guerra Civil o Estado espanhol passou a incentivar e investir na industrialização e crescimento da capital, como forma de contrabalançar o poder econômico das duas regiões mais industrializadas da Espanha: a Catalunha e o País Basco, ambas com pretensões autonomistas. Desse modo,

a firme vontade centralista do poder cristalizou-se realmente em Madrid para lograr um pólo industrial na capital que pudesse competir com o País Vasco e a Cataluña (...). A partir deste momento, o crescimento de Madrid se acelera pela demanda de trabalho suscitada pelo novo pólo industrial. ${ }^{44}$

A exemplo do que ocorreria no Brasil poucos anos depois, a condução desse desenvolvimento industrial desigual e autoritário sobre o território, elegendo regiões modernas e relegando outras ao atraso, promoveu uma intensa migração das populações camponesas das regiões mais pobres da Espanha para o pólo dinâmico de Madri. Como aqui, essas populações foram se instalar em moradias provisórias e precárias, grande parte das vezes em ocupações irregulares, denominadas chabolas (favelas).

A política habitacional espanhola era altamente centralizada e levada a cabo por dois órgãos diretamente ligados ao governo central: o INV - Instituto Nacional de La Vivienda, criado em 1939, por meio de uma lei que também cria a figura da vivienda protegida, destinada a viabilizar a "moradia mínima" às camadas de baixa renda; e a OSH - Obra Sindical del Hogar, criada em 1942, destinada ao planejamento, execução e financiamento da produção de moradias sociais. O I Plan Nacional de Vivienda 1944-1954 previa a construção de 1.400 .000 moradias (entre novas unidades e reformas em

\footnotetext{
${ }^{43}$ Cf. DÍAZ, Jesús López. La Vivienda Social en Madrid in Revista Espacio, Tiempo y Forma, Serie VII, Historia del Arte, no 15. UNED, 2002, p. 301-2.

${ }^{44}$ ARIAS et alli. El Crecimiento de Madrid desde la Guerra Civil. Comunicação apresentada em maio de 1976 ao Seminario de Urbanismo del Centro de Perfeccionamiento de Ingenieros de Caminos, in El Caso de Madrid - Lecturas sobre la Producción Monopolista del Espacio. Depto. de Publicaciones de Alumnos, ETSAM/UPM, 1981-82, p. 11-2 apud NEGRELOS, Eulalia Portela. Remodelação de Bairros Populares em São Paulo e Madrid 1976-1992: Projeto e Participação Popular. Dissertação de Mestrado apresentada à FAUUSP. São Paulo: FAUUSP, 1998, p. 59
} 
danificadas), estimando-se em 25\%, dentre estas, o total de moradias "protegidas". Não se logrou atingir metade dessa meta ${ }^{45}$.

No ano de 1946 foi aprovada a Ley de Ordenación Urbana de Madrid, obra de Pedro Bidagor, em que se ordenava a expansão da cidade por meio de um zoneamento que localizava as zonas industriais e as zonas residenciais das classes trabalhadoras afastadas e segregadas da cidade burguesa por "anéis verdes", configurando núcleos satélites relativamente auto-suficientes, coincidindo, aproximadamente, com os povoados existentes no entorno da capital. Em fins dos anos 1940 essas áreas já haviam se tornado cobiçadas pela especulação imobiliária, em busca de solo urbanizado a baixo preço, não tendo se viabilizado seu intento original ${ }^{46}$.

Mas foi a partir da década de 1950 que o Estado espanhol empreendeu novas e importantes iniciativas com vistas à erradicação do fenômeno do chabolismo, a partir de uma política de produção habitacional massiva. Essa década vê um crescimento da migração anual campo-cidade a 229.000 pessoas, frente à média anual de 105.000 pessoas vista na década anterior ${ }^{47}$.

Frente ao fracasso do primeiro Plano Nacional de Habitação, é elaborado o II Plan Nacional de la Vivienda em 1955, que constata a necessidade de construção anual de 110.000 novas moradias em toda a Espanha. Ao INV foi delegada a implementação do plano na região de Madri. Novamente, o plano só cumpriu atingir metade de sua meta ao longo de seus cinco anos de aplicação prevista ${ }^{48}$.

Na segunda metade da década de 1950 foi iniciada a construção dos poblados de absorción, destinados a receber os moradores removidos de favelas que não tinham condições de integrar-se ao mercado imobiliário formal. Teoricamente, tratava-se de moradias provisórias, que corresponderiam a um momento transitório entre a chabola e a habitação capitalista formal. Devido a isso as unidades eram extremamente exíguas e os bairros, mal equipados ${ }^{49}$.

Um caso exemplar dessa política é o Poblado de Absorción General Ricardos, implantado em 1958. Construído dentro do mais estrito racionalismo funcionalista, General Ricardos consistia, em seu projeto original, de 600 unidades, ampliadas posteriormente para 1.070, agrupadas em 30 edifícios laminares de 4 ou 5 andares e duas torres de 12

\footnotetext{
${ }^{45}$ Cf. DÍAZ, Jesús López. Op. Cit., 2002, p. 314.

${ }^{46}$ Cf. DÍAZ, Jesús López. Op. Cit., 2002, p. 308.

${ }^{47}$ Valores correspondem a toda a Espanha.

${ }^{48}$ Cf. DÍAZ, Jesús López. Op. Cit., 2002, p. 322-7.

${ }^{49}$ Cf. NEGRELOS, Eulalia Portela. Op. Cit., 1998, p. 68.
} 
pavimentos, de uso estritamente residencial. As unidades eram bastante exíguas $-37,12$ $\mathrm{m}^{2}$ - com pé-direito de apenas $2,25 \mathrm{~m}$, além de que todas as unidades apresentavam o mesmo programa, indistintamente ${ }^{50}$.

No ano de 1957 foi instituído o Plan de Urgencia Social de Madrid, que compelia a iniciativa privada a construir 60.000 moradias de proteção oficial no prazo de cinco anos, fomentando a edificação dos Poblados Dirigidos com o intuito de frear e ordenar a ocupação anárquica das periferias da cidade. Para sua execução foram contratados alguns dos melhores arquitetos do momento, que idealizaram conjuntos que se coadunavam aos princípios do modernismo racionalista. A necessidade de se construir a baixo custo levou à utilização de materiais de baixíssima qualidade que acabaram por comprometer a própria habitabilidade desses conjuntos ${ }^{51}$.

Os poblados dirigidos constituíam-se em iniciativas para produzir unidades habitacionais voltadas às populações recém-chegadas às cidades, mas com condições, porém, de construir ou adquirir a própria moradia. Esse processo visava organizar porções do território por meio de assessoria, projeto e financiamento por parte do Estado, o que, de outra forma, seria realizado individual e anarquicamente por essas populações, contribuindo para a produção de uma periferia (mais) caótica. Os poblados dirigidos foram, ainda, meio para o enfrentamento do problema do desemprego, ao incorporar seus futuros moradores como mão de obra na construção desses conjuntos ${ }^{52}$.

O impulso tomado pela produção habitacional massiva através da implantação dos polígonos de vivienda a partir da década de 1950 incorpora definitivamente os princípios da ortodoxia racionalista funcionalista. A adoção dos cânones do modernismo dos CIAM, ao privilegiar as questões de habitação mínima e salubridade, favorecendo a redução dos custos e os aspectos quantitativos em lugar dos qualitativos, acabou relegando ao segundo plano a questão da morfologia urbana resultantes dessas intervenções. O desenho urbano acabou por receber pouca atenção dentro dos projetos dos conjuntos, a partir da premissa, que se mostrou equivocada, de que todo "solo não ocupado pela edificação e pelo viário mínimo é zona verde" ${ }^{\text {53 }}$.

\footnotetext{
${ }^{50}$ NEGRELOS, Eulalia Portela. Op. Cit., 1998, p. 143-5.

${ }^{51}$ Cf. BLOS, Dorotea. Los Polígonos de Vivienda Social: perspectivas hacia su recuperación en España, Francia y Brasil. Volume II. Tese de doutorado apresentada à Escola Técnica Superior de Arquitectura de Barcelona / Universitat Politècnica de Catalunya. Barcelona: ETSAB/UPC, 1999, p. 9.

52 Cf. MALUENDA, Ana María Esteban. La vivienda social española en la década de los 50: un paseo por los poblados dirigidos de Madrid. Cuaderno de Notas 7. Madrid: ETSAM/UPM, 1999, p. 57.

53 MOYA GONZALEZ, Luis. Barrios de Promoción Oficial Madrid 1939-1976. La Política de Promoción Pública de Vivienda. Madrid: COAM, 1983, p. 106 apud BLOS, Dorotea. Op. Cit., 1999, p. 67.
} 
Com relação à aplicação desse racionalismo estrito na concepção dos conjuntos habitacionais espanhóis dessa fase, tratando especificamente do caso dos poblados de absorción, a exemplo de General Ricardos, BLOS observa que essa política resultou em

\begin{abstract}
áreas muito pouco estruturadas, com um sistema viário mal definido, caracterizado por um sistema de vias perimetrais e outras que cortam o conjunto ou o penetram em 'cul de sac', e onde os blocos isolados são dispostos geralmente paralelos entre si e buscando a orientação norte-sul, sem uma relação mais direta com a rua que Ihes dá suporte. O baixo orçamento destinado a estas atuações e seu caráter provisório é, em grande parte, o responsável pela baixa qualidade do produto final, tanto pelos péssimos materiais empregados nas edificações como pela carência de qualquer tratamento dos espaços exteriores. ${ }^{54}$
\end{abstract}

Entre os anos de 1950 e 1972 foram construídas, no município de Madri, 94.518 unidades habitacionais de interesse social de promoção pública. Destas, quase $70 \%$ (65.803 unidades) foram construídas entre 1950 e 59. Na região de Barcelona, nesse mesmo período, foram construídas 62.553 moradias socais. Aí, porém, a produção de maior vulto ocorreu no período posterior: 74\% dessa produção (46.477 unidades) se deu entre 1960 e $1972^{55}$. Nesse período a população de Madri saltou de 1.618.435, em 1950, para 2.259.931 em 1960, atingindo 3.146.071 habitantes dez anos depois. O município de Barcelona apresentou variação populacional de 1.280.179 habitantes em 1950, aparecendo com 1.557 .863 e 1.745 .142 habitantes nos dois Censos subseqüentes ${ }^{56}$.

$\mathrm{Na}$ França aproximadamente 450.000 moradias foram destruídas durante a Segunda Guerra Mundial, o que representava cerca de $5 \%$ do parque imobiliário residencial existente antes do conflito, além de quase um milhão de residências danificadas em maior ou menor grau. A esse quadro ainda é preciso somar o déficit pré-existente de moradias, decorrente da migração rural-urbana, que não havia sido solucionado antes da guerra, bem como a demanda por moradias aos repatriados da Argélia, os pied-noirs ${ }^{57}$. Além disso, a infra-estrutura encontrava-se em destroços, o que dificultava sobremaneira o esforço de reconstrução e a promoção de condições de habitabilidade e salubridade às

\footnotetext{
${ }^{54}$ BLOS, Dorotea. Op. Cit., 1999, p. 68-9. Grifo no original

55 Cf. FERRER I AIXALA, Amador. La vivienda masiva y la formación metropolitana de Barcelona. Los polígonos de viviendas en Barcelona 1950-1975. Tesis Doctoral. Barcelona, Escuela Técnica Superior de Arquitectura de Barcelona, 1982, p. 30-2 e MOYA GONZALEZ, Luis. Op. Cit., 1983, p. 64-77 apud BLOS, Dorotea. Op. Cit., 1999, p.80.

56 INE - Instituto Nacional de Estadística. Censos de Población desde 1900: Censos de 1950, 1960 y 1970. Acessado em 26 de setembro de 2008 e baixado do sítio do INE do endereço: http://www.ine.es/inebaseweb/71807.do?language=0.

${ }^{57}$ Estimava-se em 13 milhões de unidades o déficit habitacional francês ao final do conflito. Cf. FARAH, Marta. Op. Cit., 1990, p. 13.
} 
cidades e populações afetadas, o que levou a que os primeiros anos do pós-guerra fossem dedicados à reconstrução dessa infra-estrutura destruída pelo conflito ${ }^{58}$.

Já em 1945 o Estado francês, com vistas ao investimento na recuperação do parque habitacional, instituiu um fundo composto por recursos advindos de uma taxa representada por uma porcentagem sobre o valor dos aluguéis, o Fundo Nacional para a Melhoria da Habitação (FNAH - Fonds National d'Amélioration de l'Habitat), o qual vai resultar, no ano de 1971, na ANAH - Agência Nacional para a Melhoria da Habitação (Agence Nationale pour l'Amélioration de l'Habitat) ${ }^{59}$.

Logo após a Segunda Guerra, no ano de 1948, foi instituída, em Paris, a Lei de Controle dos Aluguéis, desincentivando o investimento privado na produção de novas unidades habitacionais e reduzindo a rotação da ocupação. Somada ao quadro de carência de moradia já existente, essa lei acabou por inviabilizar o acesso à moradia às camadas de menor renda da população residentes na metrópole de Paris. Estes segmentos não apresentavam condições financeiras de serem atendidos pelo mercado imobiliário capitalista, altamente especulativo com os valores da terra urbana. Este quadro gerou pressões de diferentes segmentos em favor de uma política habitacional pública: dos industriais ao Partido Comunista, passando pelo movimento social cristão, todos exigiam do Estado uma resposta à crise da moradia.

A França constituiu, sobretudo ao longo da segunda metade do século $X X$, um dos mais significativos arcabouços institucionais para o suprimento habitacional, articulando diversas ações, recursos e agentes institucionais com vistas ao atendimento às diferentes demandas por moradia. Dentre os agentes envolvidos no atendimento habitacional às camadas de menor renda destacam-se: 1) os organismos de HLM Habitação de Aluguel Controlado (Habitation à Loyer Modéré); 2) as municipalidades; e 3) as associações sem fins lucrativos ${ }^{60}$.

${ }^{58}$ Cf. BENEVOLO, Leonardo. Op. Cit., 2006, p. 674.

${ }^{59}$ Cf. BOUCHÉ, Nancy. A Reabilitação na França - Instrumentos e Procedimentos. In: Apostila do Curso Gestão de Programas de Reabilitação Urbana. São Paulo: LABHAB/FAUUSP, 2000, p. 9. A ANAH tem por finalidade financiar a reabilitação da habitação privada. Seu orçamento é composto por um imposto incidente sobre $2,5 \%$ do valor dos aluguéis de todos os imóveis com mais de 15 anos. Esse fundo permite que a ANAH financie a reforma e reabilitação de moradias de aluguel com mais de quinze anos ou desocupadas. Em contrapartida os proprietários se vêem obrigados a alugar esses imóveis, pelos dez anos subseqüentes, por um valor pré-estabelecido. Cf. COULON Jean-Yves. Financiamento Francês da Reabilitação. In: Apostila do Curso Gestão de Programas de Reabilitação Urbana. São Paulo: LABHAB/FAUUSP, 2000, p. 4.

${ }^{60}$ As associações sem fins lucrativos buscam oferecer soluções habitacionais a populações em grandes dificuldades, sem condições de recorrer aos organismos de HLM. Exemplo disso são as associações PACT-ARIM, direcionadas à aquisição de imóveis, reabilitação e aluguel a essas populações. As municipalidades atuam, também e muitas vezes, como agentes promotores, na forma de recuperação 
Os organismos de HLM derivam das primeiras associações de habitação econômica criadas no início do século XX, as associações de HBM - Habitations à Bon Marché. Os resultados colhidos pelos organismos HLM, criados em 1950, impressionam: os cerca de 1.400 organismos de HLM são responsáveis diretos pelo atendimento habitacional de aproximadamente um quarto da população francesa, atingindo 13 milhões de pessoas, sendo 9 milhões de locatários e 4 milhões de proprietários. Isto representa um parque de 3,4 milhões de moradias alugadas e mais 1,25 milhões construídas com programas de financiamento à casa própria ${ }^{61}$.

Em 1953 o governo instituiu o Plan Courant, que objetivava a edificação anual de 240.000 moradias e reestruturava a política nacional francesa de habitação. Três medidas principais marcaram essa nova orientação da política habitacional implementada a partir de então: a criação de uma contribuição a ser paga por todas as empresas referente a 1\% do valor dos salários para a constituição de um fundo especial para moradias públicas; concessão ao governo e às municipalidades de amplo controle e poder sobre os terrenos destinados ao desenvolvimento urbano, instituída através da Lei do Solo de 1953 (Loi Foncière); e a constituição de uma nova empresa urbanizadora paraestatal com a finalidade de construir moradias públicas com recursos da poupança administrada pelo governo, a SCIC - Sociéte Centrale Immobilière de la Caisse de Dépôts ${ }^{62}$.

A demanda era tão premente que a SCIC passou a trabalhar imediatamente, adquirindo terrenos distantes e subequipados em áreas com características rurais, sem interesse para o mercado imobiliário formal. Este órgão passou a produzir os grandes

de edifícios vazios e/ou degradados, buscando financiamento para sua conversão e locação. Cf. COULON, Jean-Yves. Op. Cit., 2000, p. 6-7.

${ }^{61}$ A atuação desses agentes encontra-se amparada financeiramente por um sistema de financiamento à produção habitacional fundada na noção da solidariedade nacional, em que o Estado subsidia as moradias com recursos majoritariamente orçamentários, ou seja, sustentadas pelos contribuintes franceses. Há quatro fontes de financiamento público à moradia: 1) créditos orçamentários, especialmente do Ministério da Habitação; 2) recursos das cadernetas de poupança, mobilizadas pela CDC - Caixa de Depósitos e Consignações (Caisse des Dépôts et Consignations); 3) contribuição dos empregadores em $1 \%$ sobre as folhas salariais (1\% logement), destinadas ao financiamento de moradias aos trabalhadores; e 4) orçamentos das coletividades locais e regionais complementares ao do Estado nacional.

Esses financiamentos são solicitados pelos organismos de HLM, coletividades locais ou entidades sem fins lucrativos com vistas à locação, moradia própria ou reabilitação. Os pedidos de empréstimos são feitos à CDC, com prazo de pagamento de 32 anos e juros baixos. Complementarmente a este empréstimo, o Estado concede um subsídio correspondente a 12,5\% do custo da operação (valor do terreno + custo da construção, definidos em função de um valor referencial), podendo atingir $20 \% \mathrm{em}$ caso de populações em grandes dificuldades. Em contrapartida é estabelecido um valor máximo para os aluguéis, a fim de que sejam acessíveis às populações de menor renda. Cf. COULON, Jean-Yves. Op. Cit., 2000, p. 6-8.

62 Cf. CASTELLS, Manuel. La Ciudad y las Masas: Sociología de los Movimientos Sociales Urbanos. Madrid: Alianza Editorial, 1983, p. 120. 
conjuntos (grands ensembles) que vão marcar indelevelmente a paisagem suburbana de Paris. Estes projetos se pautaram pela busca de se produzir o maior número de unidades ao menor custo possível.

A promoção de grandes conjuntos teve início em 1954/1955, mas ganhou força a partir de 1958 com a criação das ZUP - Zonas de Urbanização Prioritária (Zones à Urbaniser en Priorité), destinadas à construção de moradias sociais, com no mínimo 500 unidades $^{63}$.

Essa política de produção dos grands ensembles desenvolveu-se, ao longo dos anos 1960, apoiada em três pilares fundamentais: 1) o controle da terra urbana por meio da aplicação de uma legislação que dava ao Estado o direito de preempção e expropriação por interesse público para a aquisição de áreas destinadas à urbanização, assim como a demarcação das ZUPs; 2) a utilização da pré-fabricação pesada e da padronização tipológica na produção habitacional massiva; 3) estímulo à participação da iniciativa privada na promoção habitacional, por meio de financiamentos especiais e incentivos a grandes construtoras e escritórios de arquitetura. O esforço nacional francês de promoção habitacional levou a um aumento de 71.000 moradias construídas em 1950 para 430.000 unidades produzidas em 1964, quando esse número se estabiliza. Os grands ensembles foram implantados, de modo geral, nas cercanias das grandes aglomerações urbanas, com destaque para a região de Paris. Dentre os fatores que acabavam por determinar a localização dos conjuntos destacam-se a proximidade com pólos industriais, a existência de grandes eixos viários nas cercanias e a conexão com a rede ferroviária de acesso ao centro urbano ${ }^{64}$.

O esforço de produção habitacional francês resultou num dos mais significativos e emblemáticos processos de industrialização da construção civil do mundo, articulando um grande parque industrial privado capitaneado pelo Estado. A industrialização da construção civil na França possibilitou a produção massiva de unidades habitacionais, resultando nos grandes conjuntos; dialeticamente, essa industrialização só foi possível em decorrência do aumento da escala da produção habitacional sob uma intensa centralização da direção dessa política sob comando do Estado nacional francês. O contexto social e econômico em que se demandou e viabilizou a industrialização da construção civil era marcado por: elevada demanda pela produção de unidades habitacionais; escassez de determinados materiais tradicionais para a construção civil; escassez de recursos financeiros (uma vez

\footnotetext{
${ }^{63}$ Cf. SLOMIANSKY, Adriana Paula. Op.Cit., 2002, p. 37.

${ }^{64}$ Cf. BLOS, Dorotea. Op. Cit., 1999, p. 17-8.
} 
que os limitados recursos existentes foram canalizados à recuperação da infra-estrutura); e escassez de mão de obra especializada ${ }^{65}$.

A ampliação da escala dos empreendimentos habitacionais permitiu a redução dos custos das unidades pelo aumento da produtividade, uma vez que a industrialização da construção permitia reduzir o custo que a mão de obra representava no preço final da habitação. Ao passo que a força de trabalho era substituída pelo maquinário da indústria se fez necessário aumentar a escala dos empreendimentos de modo a que se desse a amortização desse investimento das indústrias, diluído por meio da repetição em grande quantidade de módulos estandardizados. O resultado dessa vinculação tão estreita entre as necessidades técnicas da pré-fabricação e seu reflexo nas demais etapas da construção - da racionalização do projeto modelado em função da otimização dos custos até os movimentos realizados pelas gruas na montagem dos elementos pré-fabricados no canteiro - foi a extrema monotonia visível nos grandes conjuntos da Paris suburbana. Da largura, comprimento ou altura dos edifícios, até a distância em que se encontravam uns dos outros, a pré-fabricação dos componentes exercia um pesado controle sobre os resultados arquitetônicos e urbanísticos ${ }^{66}$. Aparentemente pouco importava qual seria a

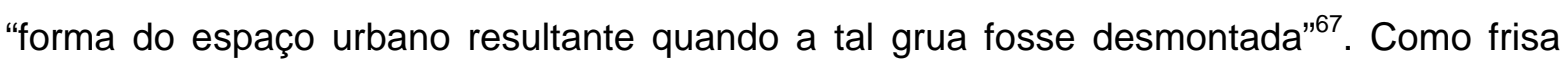
BRUNA, um entusiasta da industrialização da construção e insuspeito na crítica,

Os "grands ensembles" da região parisiense testemunham de forma insofismável que a repetição de blocos sempre iguais, que a somatória linear de mesmas unidades formando gigantescas serpentinas, retas ou sinuosas, (...) não são suficientes para formar espaços urbanos com escala e dimensões humanas ${ }^{68}$.

Entre 1958 e 1964 foram criadas 155 ZUPs, totalizando uma área de 17.000 hectares, as quais apresentavam um potencial de edificação de aproximadamente 655 mil unidades habitacionais. Desse total, apenas 2.800 hectares encontravam-se ocupados de alguma forma, em 120 ZUPs, no ano de 1964, apresentando 33.200 moradias construídas e 57.400 em construção, denotando a dificuldade em se operacionalizar essas zonas ${ }^{69}$.

O resultado dessa produção, sobretudo a da primeira geração (1955-1963), foi bastante criticado, tendo grandes impactos sobre a opinião pública. O próprio instrumento normativo instituído para viabilizar a produção habitacional massiva - as ZUP - acabou por

65 Cf. BRUNA, Paulo J. V. Arquitetura, industrialização e desenvolvimento. São Paulo: tese de doutoramento apresentada à FAUUSP: FAUUSP, 1972, p. 49.

${ }^{66}$ Cf. BRUNA, Paulo J. V. Op. Cit., 1972, p. 28, 31.

${ }^{67}$ LAMAS, José Manuel Ressano Garcia. Op. Cit., 2007, p. 362.

${ }^{68}$ BRUNA, Paulo J. V. Op. Cit., 1972, p. 31-2.

${ }^{69}$ Cf. BLOS, Dorotea. Op. Cit., 1999, p. 24. 
uniformizar as soluções urbanísticas utilizadas. Somando-se a isso a padronização decorrente da industrialização, o resultado foi a extrema monotonia e rigidez visível nos grands ensembles. A degradada qualidade de vida nesses espaços, carentes dos mais básicos serviços urbanos, como escolas, equipamentos culturais, comércios e transportes públicos suficientes, associada à "estética" dos grandes conjuntos, que passaram a dominar os subúrbios parisienses, mobilizou uma intensa reação negativa a esses territórios que não chegavam a ser cidade. A rejeição a esse modelo se agudizava, possivelmente, devido ao "contraste entre uma das mais ricas culturas do mundo - ao longo das margens do Sena - e a experiência de reduzir o assentamento urbano a um dormitório de concreto proporcionado pelo Estado"70.

O primeiro grand ensemble implantado na região metropolitana de Paris foi o de Sarcelles, cuja construção teve início no ano de 1954, na região ocupada por um pequeno vilarejo rural que contava, a essa época, com não mais de 1.500 habitantes, e se localizava a cerca de $15 \mathrm{~km}$ ao norte de Paris. O projeto original previa a construção de mil unidades habitacionais; quando de sua conclusão em 1974, porém, contava com mais de 13.000 unidades e aproximadamente 60.000 habitantes $^{71}$.

O projeto, construção e administração de Sarcelles ficou a cargo da SCIC, que implantou três diferentes modelos de moradia de acordo com distintos momentos econômicos e demandas sociais que se apresentaram ao longo de sua implementação. Numa primeira fase, entre 1954 e 1960, foram edificados cinco bairros - Sarcelles 1, 2, 3, 4 e 5 - com moradias púbicas de tipo HLM, destinadas a um vasto espectro social e nos quais predominavam os operários manuais e auxiliares de escritório. A partir de 1960 até 1966, a melhoria das condições econômicas na França e a hegemonia política dos conservadores levou a SCIC a buscar formas de investimentos mais lucrativos, o que a levou a elevar o valor dos aluguéis e o padrão das novas moradias construídas nos bairros de Sarcelles 6 e 7. Essas ações acarretaram na elevação do status social do conjunto e na diminuição da proporção de operários manuais e na ampliação de técnicos e funcionários administrativos. Na última fase de implantação, dos conjuntos Sarcelles 8 e 9, entre 1966 e 1974, buscou-se atrair para a região um morador de mais alto poder aquisitivo, para o qual se constituiu uma política voltada à aquisição da moradia, por meio de empréstimos governamentais com juros baixos, levando a uma atração de populações de classe média. CASTELLS sintetiza a atuação do ente público em Sarcelles e a evolução da estrutura social do conjunto identificando a aplicação de três políticas habitacionais, que procuravam

\footnotetext{
${ }^{70}$ CASTELLS, Manuel. Op. Cit., 1983, p. 121.

${ }^{71}$ Cf. CASTELLS, Manuel. Op. Cit., 1983, p. 125.
} 
responder às demandas e condicionantes que se apresentaram e se alteraram ao longo dos 20 anos que decorreram entre o início e o término de sua implantação: 1) a resposta à crise habitacional premente no imediato pós-guerra, e que se estendeu, com intensidades variáveis por todo o período; 2) a tentativa de se viabilizar o investimento privado lucrativo na área da moradia pública; e 3) a procura por desvencilhar-se da imagem da moradia pública de aluguel para baixa renda em prol da abertura para um novo mercado voltado à propriedade privada da moradia à classe média $^{72}$.

Sarcelles, primeiro dos grandes conjuntos, laboratório de experimentações projetuais e construtivas, tornou-se emblemático por representar aquilo que a sociedade francesa negou como espaço urbano, ao ponto de chegar a nomear a enfermidade psicológica que se associava à alienação urbana provocada pelo cotidiano nos grandes conjuntos: a sarcellitis ${ }^{73}$. Apesar de ser o "mais tristemente famoso", Sarcelles não congregava o que de pior se projetou ou se construiu dentre os grands ensembles; ainda assim, é a demonstração cabal de "que a simples resolução dos problemas tecnológicos inerentes à produção não é suficiente para suprir a ausência de imaginação social e espacial" 74 .

CASTELLS analisa de que maneira a baixa qualidade ambiental resultante no conjunto de Sarcelles levou a uma mobilização de seus moradores com o intuito de pressionar o Estado por melhorias urbanas e nas unidades habitacionais, primeiramente de uma forma mais ativa e menos institucionalizada e, posteriormente, de uma maneira mais política e com maior eficácia. Ele encontra as raízes dessa mobilização no fato de, por um lado, a reivindicação dirigir-se a apenas um ente público - a SCIC - "urbanizador, proprietário e administrador de todos e cada um dos edifícios da cidade, assim como a instituição responsável pela produção e entrega de todo o equipamento urbano essencial” ${ }^{75}$. Desse modo, toda a demanda era canalizada para uma face bem visível do aparelho burocrático estatal. Por outro lado, a própria precariedade urbanística e ambiental dos conjuntos de Sarcelles acabava por galvanizar as reivindicações e promover a mobilização por melhorias. Dessas mobilizações ele identifica o surgimento do que ele define como "sindicalismo urbano", meio de luta política efetivada a partir da associação que os residentes no conjunto estabeleceram para reivindicar melhorias, e que resultará na

\footnotetext{
${ }^{72}$ Cf. CASTELLS, Manuel. Op. Cit., 1983, p. 126.

${ }^{73}$ Cf. CASTELLS, Manuel. Op. Cit., 1983, p. 123.

${ }^{74}$ BRUNA, Paulo J. V. Op. Cit., 1972, p. 32.

${ }^{75}$ CASTELLS, Manuel. Op. Cit., 1983, p. 127.
} 
eleição de um prefeito comunista para a cidade em 1965, constituindo-se na primeira vitória eleitoral do PCF para um governo local de um município suburbano não-operário.

A pressão exercida pela ação combinada dos moradores, organizados sob a AS Association Sarcelloise, entre 1957 e 1968, e da prefeitura administrada pelo Partido Comunista a partir de 1965, acabaram por converter Sarcelles de uma cidade de simples reprodução da força de trabalho para a categoria de uma cidade avançada de nível médio, configurando-se num município suburbano razoavelmente bem equipado, com amplas instalações comerciais, culturais, serviços sociais e boas escolas ${ }^{76}$.

Já em princípios dos anos 1960 apareceram as primeiras críticas ao modelo representado pela produção em larga escala dos grands ensembles, partindo do meio da própria administração e prenunciando os futuros problemas físicos e a crise social que se abateria sobre essas áreas. Em relatório apresentado ao Conselho Econômico e Social do Ministério da Construção em 29 de junho de 1960, Guy Houist, membro da "Comissão de Estudo dos Grandes Conjuntos", descrevia assim o resultado da política de produção dos grands ensembles do pós-guerra:

A desesperante mediocridade da escolha apressada de certas localizações, a evidente monotonia ortogonal de alguns projetos, a linear uniformidade de inúmeras concepções arquitetônicas, a grande insuficiência de equipamentos comuns no momento da entrega das moradias, as indiscutíveis dificuldades de transportes, a carência de isolamento acústico em inúmeras habitações, a falta de um acolhimento humano, tudo isto justifica os julgamentos prematuros e parcialmente falsos, porém de grande bom senso ${ }^{77}$.

Essas primeiras críticas ao modelo urbano adotado nos grandes conjuntos franceses motivou o surgimento de propostas que apresentavam novas morfologias urbanas e tipologias de edificação, procurando, com isso, romper com a imagem que se identificava nos grands ensembles tão vinculada ao racionalismo funcionalista da Carta de Atenas. As ZUPs eram objeto de inúmeras e variadas críticas, que BLOS sintetiza em três aspectos fundamentais: com relação aos procedimentos (principalmente no que se refere à

\footnotetext{
${ }^{76}$ Cf. CASTELLS, Manuel. Op. Cit., 1983, p. 132.

77 HOUIST, Guy. Rapport au Conseil économique et social, 29 juin 1960 apud FOURCAUT, Annie. Trois discours, une politique? Revista Urbanisme $n^{\circ} 322$, jan/fev 2002, p. 42 . Nesse mesmo ano de 1960 foi instituído o PADOG - Plano de Ordenamento e Organização da Região de Paris), com o intuito de regular o crescimento da região da capital francesa, prevendo um acréscimo de um milhão de habitantes na década seguinte, $75 \%$ disso nos boulevard périphériques. Este plano já previa a necessidade de uma reestruturação da periferia (banlieue), para a qual se previa a constituição de quatro centros satélites, ao mesmo tempo em que propunha a transferência de parte importante do desenvolvimento da capital para cidades médias num raio de cem quilômetros de Paris. A partir de 1965, até 1970, teve início a implantação do programa de villes nouvelles, prevendo a implantação de cinco novas cidades na região de Paris e mais quatro em diferentes regiões da França, com tamanhos previstos entre 140.000 e 500.000 habitantes. Cf. BENEVOLO, Leonardo. O Último Capítulo da Arquitetura Moderna. Lisboa: Edições 70, 1997, p. 63, 65.
} 
insatisfação das administrações locais com a execução de grandes intervenções sobre as quais tinham pouco ou nenhum controle), aos programas (com relação à rigidez programática, definida em função de relações de habitantes por equipamento) e à qualidade dos espaços resultantes (relacionada à constatação da mediocridade do conjunto da produção). Em 1961 foi realizado o concurso de projeto para a ZUP de Toulouse-le-Mirail, vencido pela equipe de Candillis-Josic-Woods, que desenvolveu, para esse conjunto urbano previsto para 100.000 habitantes, uma proposta que recupera as noções de centralidade, hierarquização dos espaços e complexidade nas funções urbanas. Em 1964 é apresentado o projeto de La Grand Borne, em Grigny, que propõe um complexo inusitado de edifícios curvos e formas labirínticas, assim como uma apartação entre o fluxo de veículos no seu perímetro exterior e a circulação de pedestres em seu interior ${ }^{78}$.

O último grande conjunto produzido na área metropolitana de Paris foi Val d'Yerres, projetado em 1965 para 6.000 unidades e construído entre 1966 e 1974. Formulado num contexto em que a crise mais aguda relativa à carência habitacional já havia sido superada e o país vivia um acelerado e sustentado crescimento econômico, a política habitacional pôde se afastar um pouco dos critérios eminentemente quantitativos da produção do período anterior na direção de um investimento maior na qualidade das habitações e dos espaços urbanos desses empreendimentos, em resposta às acerbas críticas que as formas urbanas dos grands ensembles vinham recebendo. Assim, a SCIC investiu num novo desenho urbano que pudesse corresponder a uma maior qualidade espacial. Para tanto, propôs-se uma implantação que apelava ao bucolismo, numa área de 312 hectares situada em meio a uma paisagem rural, $25 \mathrm{~km}$ ao sudeste de Paris, onde se buscava "uma cidade-jardim em grande escala"79.

Esse conjunto procurou romper com a imagem tradicional dos grandes conjuntos públicos ao tirar partido, em sua implantação, do ambiente natural do terreno original, sobre o qual se interveio de modo a evitar a monotonia presente nas experiências anteriores por meio da valorização de uma diversidade arquitetônica:

Em vez de reproduzir os gigantescos edifícios de múltiplos pavimentos em fileiras paralelas, típicos da maioria dos Grands Ensembles, em Val d'Yerres modelou-se uma série de unidades urbanas projetadas cada uma a seu modo, espalhadas pelo espaço aberto natural. (...) E, pela primeira vez nas moradias públicas francesas, foram edificadas habitações unifamiliares em um Grand Ensemble, alternadas com

\footnotetext{
78 Cf. BLOS, Dorotea. Op. Cit., 1999, p. 25. Apesar dessa inovação na forma urbana do conjunto La Grande Borne este foi objeto de inúmeras ações dos diversos programas de reabilitação desenvolvidos na França desde os anos 1970.
}

${ }^{79}$ CASTELLS, Manuel. Op. Cit., 1983, p. 136. 
edifícios de vários pavimentos e altura moderada, e construção de uma qualidade a que não se estava acostumado ${ }^{80}$.

Esta diversidade referia-se não apenas à tipologia dos edifícios, mas, também, a uma desejada diversidade de segmentos sociais, o que se buscava pelos variados formatos que se previa no acesso às unidades, através de compra ou locação de variados tipos de habitações. Do total das unidades HLM, 27\% eram destinadas ao poder público local, o qual as deveria destinar àqueles segmentos que apresentavam a demanda mais urgente por habitação.

A concepção do conjunto, orientada ao convívio comunitário, buscava a redução da segregação social ao mesmo tempo em que investia na diversidade espacial e social. Essa opção carregava em si a contradição de que a localização dos diversos grupos sociais em moradias com qualidades e preços distintos tendia a reproduzir as condições de segregação espacial.

A despeito dessa iniciativa com vistas a responder às críticas aos grands ensembles por meio do incentivo à diversidade, promovendo um projeto que procurava contemplar e recriar algo da complexidade inerente à cidade tradicional, Val d'Yerres não teve mais sucesso que os conjuntos anteriores, dos quais é herdeiro:

Projetado como o novo perfil urbano e para superar a oposição da sociedade aos primeiros Grands Ensembles, Val d'Yerres chegou a ser, ao contrário, a expressão máxima das contradições dessa política nacional de habitação. Com a promessa de um bom entorno à classe média, de uma moradia de aluguel barata aos trabalhadores e de um investimento rentável ao capital, a SCIC buscou demonstrar como as contradições urbanas poderiam ser superadas por meio do desenho urbano. Val d'Yerres deveria ser a primeira cidade-jardim da França pós-industrial, mas acabou sendo o último Grand Ensemble da Paris suburbana ${ }^{81}$.

Em 1967 a nova Lei do Solo (Loi d'Orientation Foncière), entre outras determinações relativas à organização do território, extinguiu o instrumento da ZUP e o substituiu pela ZAC - Zona de Ordenamento Concertado (Zone d'Aménegement (Concerté) $)^{82}$. A partir de então a escala dos conjuntos foi sendo reduzida de modo a

\footnotetext{
${ }^{80}$ CASTELLS, Manuel. Op. Cit., 1983, p. 136.

${ }^{81}$ CASTELLS, Manuel. Op. Cit., 1983, p. 144.

82 "As ZAC são zonas em cujo interior uma coletividade pública decide intervir para realizar, ou fazer realizar, o reordenamento e as obras públicas dos terrenos, com vistas a cedê-los ou alugá-los a utilizadores públicos ou privados, a fim de que eles realizem obras públicas e edificações, de caráter público ou privado, que entre num projeto de conjunto.
}

A ZAC é um instrumento 'voluntarista', de iniciativa e de interesse público, que serve de quadro para reordenar e provê-los de obras públicas. Essa ferramenta apresenta a vantagem de agrupar os três principais componentes do reordenamento operacional, que são: a regra de urbanismo, a direção imobiliária e o financiamento. 
diminuir seu impacto sobre os tecidos urbanos existentes, além do paulatino abandono da pré-fabricação pesada na produção habitacional.

A reconstrução francesa do pós-guerra, pela própria magnitude dos problemas e das carências envolvidos, fez com que se priorizassem os aspectos quantitativos do problema em lugar dos qualitativos. A necessidade de produção rápida de unidades habitacionais, a baixo custo, produziu grandes extensões de espaços monofuncionais, segregados e alienados da cidade consolidada.

As críticas a esse modelo de produção do espaço urbano motivou a decretação de uma norma proibindo a construção de novos grandes conjuntos na França em 1973, chamada Circular Guichard $^{83}$, em que se vedou a construção de qualquer conjunto residencial com mais de 2.000 unidades habitacionais em cidades com mais de 50 mil habitantes. Aquelas com população menor que esta não poderiam albergar conjuntos com mais de mil unidades ${ }^{84}$.

Essa circular, assinada em 21 de março de 1973, visava "prevenir a realização das formas de urbanização ditas 'grands ensembles' e lutar contra a segregação social pelo hábitat", com os objetivos explícitos de "impedir a realização das formas urbanas designadas geralmente sob o nome de 'grands ensembles' pouco conformes às aspirações dos moradores e sem firmes justificativas econômicas" ${ }^{\prime 5}$.

Contudo, é forçoso observar que a essa época o esforço de reconstrução já havia se encerrado, de onde se depreende que os mesmos só foram abandonados quando não se faziam mais necessários. Além disso, é inegável o sucesso representado pela promoção dos grandes conjuntos referente ao atendimento das demandas por moradia - enfocado no atendimento quantitativo e não qualitativo, é verdade.

Esse modelo foi extremamente bem-sucedido se se põe em perspectiva histórica este momento em contraste ao período logo anterior à Segunda Guerra Mundial, em que o

A ZAC é um procedimento adaptado para empreender novas urbanizações, ou re-estruturar amplamente zonas sub-utilizadas ou em terrenos incultos: ela é concebida para criar novos lotes de terrenos, ou para tratar dos pequenos pontos a serem demolidos e a serem reorganizados, nos locais onde as infra-estruturas e obras públicas são necessárias, prover os serviços para os mesmos, e depois revendê-los a construtores, segundo um preço e uma lista de encargos estabelecidos pelo organismo que, a pedido do município e sob seu controle, tenha o papel de 'reordenador'. Se este for o próprio município, um organismo público, por exemplo uma Sociedade de Economia Mista de reordenamento, a aquisição dos imóveis pode ser feita por desapropriação." BOUCHÉ, Nancy. Op. Cit., 2000, p. 47-8.

${ }^{83}$ Olivier Guichard foi Ministro do Planejamento Territorial de 1968 a 1979, e Ministro do Planejamento Territorial, do Equipamento, da Habitação e do Turismo de 1972 a 1974.

${ }^{84}$ FOURCAUT, Annie. Op. Cit., 2002, p. 44.

${ }^{85}$ FOURCAUT, Annie. Op. Cit., 2002, p. 44. 
problema da habitação às classes operárias achava-se muito distante de uma solução ou, minimamente, de um equacionamento.

De fato, conforme pesquisa realizada em 1964 nos grands ensembles, 88\% da população residente se dizia convenientemente alojada, além de $62 \%$ que afirmavam que as vantagens da vida nos grandes conjuntos superavam os inconvenientes, bem como $51 \%$ dos entrevistados que diziam pretender viver muito tempo nesses locais. Para as populações atendidas por essa política, normalmente oriundas do meio rural ou de setores urbanos bastante precários, a instalação nesses conjuntos representava o acesso a uma moradia e a um espaço urbano qualificados, com as promessas de salubridade e bemestar da sociedade moderna. Nessa mesma enquete surgiram, porém, aqueles que identificaram problemas relacionados a defeitos nas unidades (24\%), distância dos centros urbanos (22\%) e falta de equipamentos (17\%). Além disso, 82\% dos entrevistados diziam preferir a moradia individual em detrimento da coletiva, enquanto 6 em cada 7 moradores gostariam que o acesso à habitação fosse através da propriedade privada, e não o aluguel $^{86}$.

As dificuldades da vida cotidiana nos grandes conjuntos vão se ampliando nos anos subseqüentes a essa pesquisa, acirrando-se a partir da crise do petróleo, no começo dos anos 1970, e do impacto que a crise econômica que se abate então sobre o país tem sobre as perspectivas de ascensão social, especialmente sobre as levas de imigrantes que a essa época passaram a ocupar os grands ensembles, substituindo a população de origem francesa que havia ascendido e se mudado dos conjuntos.

Dentre os problemas urbanísticos e arquitetônicos presentes nos grands ensembles, fruto da formatação equivocada das políticas habitacionais ou de decisões projetuais infelizes - e que vão parecer ainda mais graves com a alteração, para pior, do contexto socioeconômico - algumas características espaciais dos conjuntos vão ser fundamentais no condicionamento do cotidiano das populações aí residentes. BLOS os identifica em três aspectos principais: "distância do centro da cidade e dos pólos de emprego, monofuncionalidade e insuficiência de espaços coletivos e equipamentos" 87.

No entanto, essa autora observa que, a despeito desses problemas relacionados a questões espaciais, as determinantes que vão impactar mais decisivamente na

86 Cf. CLERC, Paul. Grands Ensembles, Banlieues nouvelles. Enquête démographique et sychosociologique. Travaux et Documents, № 49. Paris, Presses Universitaires de France, 1967, p. 414 apud BLOS, Dorotea. Op. Cit., 1999, p. 157.

${ }^{87}$ BLOS, Dorotea. Op. Cit., 1999, p. 165. 
degradação dos conjuntos são aquelas relativas a questões econômicas e sociais. Assim, ela identifica como três as causas principais da crise dos grands ensembles:

A crise econômica, relacionada com a economia do país, fato que nos grands ensembles se fez sentir com maior força devido à baixa qualificação profissional e formação dos residentes; uma crise de identidade, gerada pela falta de raízes e de referências dos residentes em seu novo hábitat, que se vê reforçada pela presença de novas culturas e modos de vida trazidos pelos imigrantes do meio rural e estrangeiros; e, por fim, a existência de altas porcentagens de jovens que vão sofrer fortemente as conseqüências destas duas crises.

Contudo, há que ressaltar que a incidência da crise econômica não é homogênea nos distintos grands ensembles nem tampouco sobre o total da população residente em cada um deles ${ }^{88}$.

Grande parte dos conflitos contemporâneos presentes nos grandes conjuntos franceses tem íntima relação com as mudanças sociais e demográficas por que o país (e esses espaços) vem passando desde, principalmente, fins dos anos 1970. Os grands ensembles parisienses, implantados na distante e segregada periferia da cidade, foram ocupados pelas massas de imigrantes ao longo das últimas décadas, que substituíram os moradores de nacionalidade francesa, e acabaram por concentrar grande parte da pobreza e dos problemas sociais, reunidos nesses espaços moldados à feição do Estado.

A saída de moradores de origem francesa, que ascenderam socialmente e procuraram fugir dos conjuntos assolados pela delinqüência e violência, levou à ocupação dos mesmos por imigrantes oriundos do norte da África. A crise econômica que atinge a França a partir dessa época é particularmente danosa a essas populações emigradas, levando à concentração nesses territórios de inúmeros problemas. A partir desse momento,

a população progressivamente foi mudando e os 'problemas' apareceram especialmente com o aumento do desemprego para os jovens. (...) Muito rapidamente, os roubos começaram a se multiplicar (as bicicletas, depois os carros) e, à pequena delinqüência quotidiana, que progressivamente se instalou, ajuntou-se a degradação dos prédios, provocando a saída das famílias que podiam. (... Surgiram) os problemas da coabitação que se multiplicaram entre a população européia e uma população de origem árabe cada vez mais numerosa ${ }^{89}$.

As características próprias a esses territórios, tais como "construção recente, habitat essencialmente coletivo, população muito jovem, taxa elevada de famílias numerosas, presença de uma forte proporção de população de origem estrangeira, forte mobilidade residencial, alta taxa de desemprego, perturbando gravemente a vida do dia-adia, etc" ${ }^{\prime \prime 0}$, potencializaram os conflitos sociais nesses espaços. Se os imigrantes norte-

\footnotetext{
${ }^{88}$ BLOS, Dorotea. Op. Cit., 1999, p. 171. Grifos no original.

${ }^{89}$ CHAMPAGNE, Patrick. Uma família integrada in BOURDIEU, Pierre (Coord.). A Miséria do Mundo. Petrópolis: Vozes, 2007b, p. 104.

${ }^{90}$ CHAMPAGNE, Patrick. A visão mediática in BOURDIEU, Pierre (Coord.). Op. Cit., 2007a, p. 77.
} 
africanos que acorreram à França em busca de melhores condições de vida antes da crise econômica acabam por aceitar com certa resignação o desemprego, "não se pode dizer o mesmo de seus filhos, que só conhecem a França, e reivindicam ser tratados como franceses" 91 .

No início dos anos 1980, desenrolaram-se diversos incidentes entre a população residente nos conjuntos habitacionais franceses e a polícia, envolvendo, sobretudo, os filhos dos imigrantes norte-africanos - os beurs - jovens "em situação de fracasso escolar, sem qualificação profissional e sem trabalho"92. Esses incidentes tiveram início no bairro de Les Minguettes, em Vénissieux, subúrbio de Lyon, apenas duas semanas após a chegada dos socialistas ao poder, resultando em carros incendiados, barricadas e coquetéis Molotov, apresentando à opinião pública francesa "o estado ruinoso de certos subúrbios e a degradação dos conjuntos habitacionais saqueados pelo vandalismo e abandonados pelos organismos do HLM" "93. Esse fato motivou a instituição de ações para a reabilitação desses espaços, coordenados pelos funcionários do DSQ - Desenvolvimento Social dos Bairros, as quais já abarcavam 400 zonas de atuação em 1990.

Em outubro de 1990, outro conflito, também nos subúrbios de Lyon, tomou as ruas de Vaulx-en-Velin, após a morte de um jovem morador durante uma batida policial. Paradoxalmente, naquele momento, o conjunto passava por obras de reabilitação, tendo sido incluído nas operações DSQ em 1987. O centro comercial, inaugurado no ano anterior no centro de Mas-du-Toureau, bairro de Vaulx-en-Velin, tornou-se um dos focos principais de saques e vandalismo que se seguiram ao incidente ${ }^{94}$.

Em outubro de 2005 a morte de dois jovens de origem norte-africana durante uma batida policial em Clichy-sous-Bois (subúrbio de Paris) detonou o último (ou melhor, mais recente) conflito entre a polícia e os moradores dos grands ensembles, o qual se espraiou por outras cidades da França e, com menos força, ao restante da Europa ocidental. $O$ mesmo roteiro, o mesmo contexto, apenas o cenário diferente. Nesse mesmo ano, o desemprego atingia $9 \%$ dos franceses étnicos, enquanto aqueles de origem estrangeira, ainda que nascidos na França, apresentavam um índice de 14\% de desempregados. Dentre os desempregados com diploma de nível universitário, 5\% eram de origem étnica

\footnotetext{
${ }^{91}$ CHAMPAGNE, Patrick. Op. Cit., 2007a, p. 77.

92 CHAMPAGNE, Patrick. Op. Cit., 2007a, p. 67.

${ }^{93}$ CHAMPAGNE, Patrick. Op. Cit., 2007a, p. 67.

${ }^{94}$ Cf. CHAMPAGNE, Patrick. Op. Cit., 2007a, p. 67-9.
} 
francesa, enquanto $25,6 \%$ dos graduados de origem étnica norte-africana encontravam-se nessa situação ${ }^{95}$.

Significativamente, o fim do Movimento Moderno é associado à implosão de um grande conjunto habitacional norte-americano: o conjunto de Pruitt-Igoe, em Saint Louis. Projeto do arquiteto Minoru Yamasaki (também autor do World Trade Center, em Nova York). Premiado na década de 1950 como adequado exemplo de aplicação dos princípios racionalistas-funcionalistas dos CIAMs, este conjunto passou a apresentar elevados índices de violência e degradação, a tal ponto que se considerou a necessidade de sua implosão, identificando no espaço a gênese dos problemas sociais e urbanísticos ali encontrados. JENCKS associa a implosão de Pruitt-Igoe à morte da Arquitetura Moderna:

A arquitetura moderna morreu em St. Louis, Missouri, 15 de julho de 1972 às 3h32 da tarde (ou em torno disso) quando o infame projeto Pruitt-Igoe, ou pelo menos boa parte de seus blocos, recebeu o golpe de misericórdia com dinamite. Primeiramente foi alvo de vandalismo, foi mutilado e desfigurado pelos seus habitantes negros e, embora milhões de dólares fossem injetados lá, na tentativa de mantê-lo vivo (consertando os elevadores quebrados, consertando janelas, repintando). Ele foi finalmente libertado de sua miséria. Bum, bum, bum.

"Sem dúvida, deveriam ser mantidas as ruínas, os escombros deveriam ter uma ordem de preservação pregada neles, de modo que mantivéssemos uma memória viva desse fracasso em planejamento e arquitetura. Como a insensatez ou ruína artificial - construído como um patrimônio inglês excêntrico do século 18 para provêlo com uma educativa lembrança criadora de ostentação e glórias - devemos aprender a dar valor e proteger nossos ostentosos desastres. Como Oscar Wilde disse "experiência é o nome que damos aos nossos erros", e há algo saudável em deixá-los partir judiciosamente espalhando por toda parte a paisagem como uma lição contínua.

"Pruitt-Igoe foi construído de acordo com as idéias mais progressistas do CIAM e ganhou um prêmio do Instituto Americano de Arquitetos quando foi projetado em 1951. Consistia em um elegante bloco contínuo de 14 pavimentos com racionais passarelas elevadas - as quais eram seguras contra os carros, mas tornaram-se inseguras ao crime - sol, espaço e verde, o que Le Corbusier chamou de os 3 prazeres do urbanismo (em vez de ruas convencionais, jardins e espaços semiprivados, as quais ele bania). Possuía uma separação entre o tráfego de pedestres e veículos, era provido de espaços de lazer e confortos locais como lavanderia, creches e centro comunitário - todos racionais substitutos dos modelos tradicionais. Além do mais, seu estilo purista, sua assepsia, metáfora hospitalar da salubridade, foi pensado para injetar, pelo bom exemplo, virtudes correspondentes em seus habitantes. ${ }^{96}$

${ }^{95}$ Cf. El Pais. Francia fracasa en su política de integración. Madri, 06 de novembro de 2005.

${ }^{96}$ JENCKS, Charles. The Language of Post-Modern Architecture. London: Academy Editions, 1978, p. 9. Tradução livre do autor. 


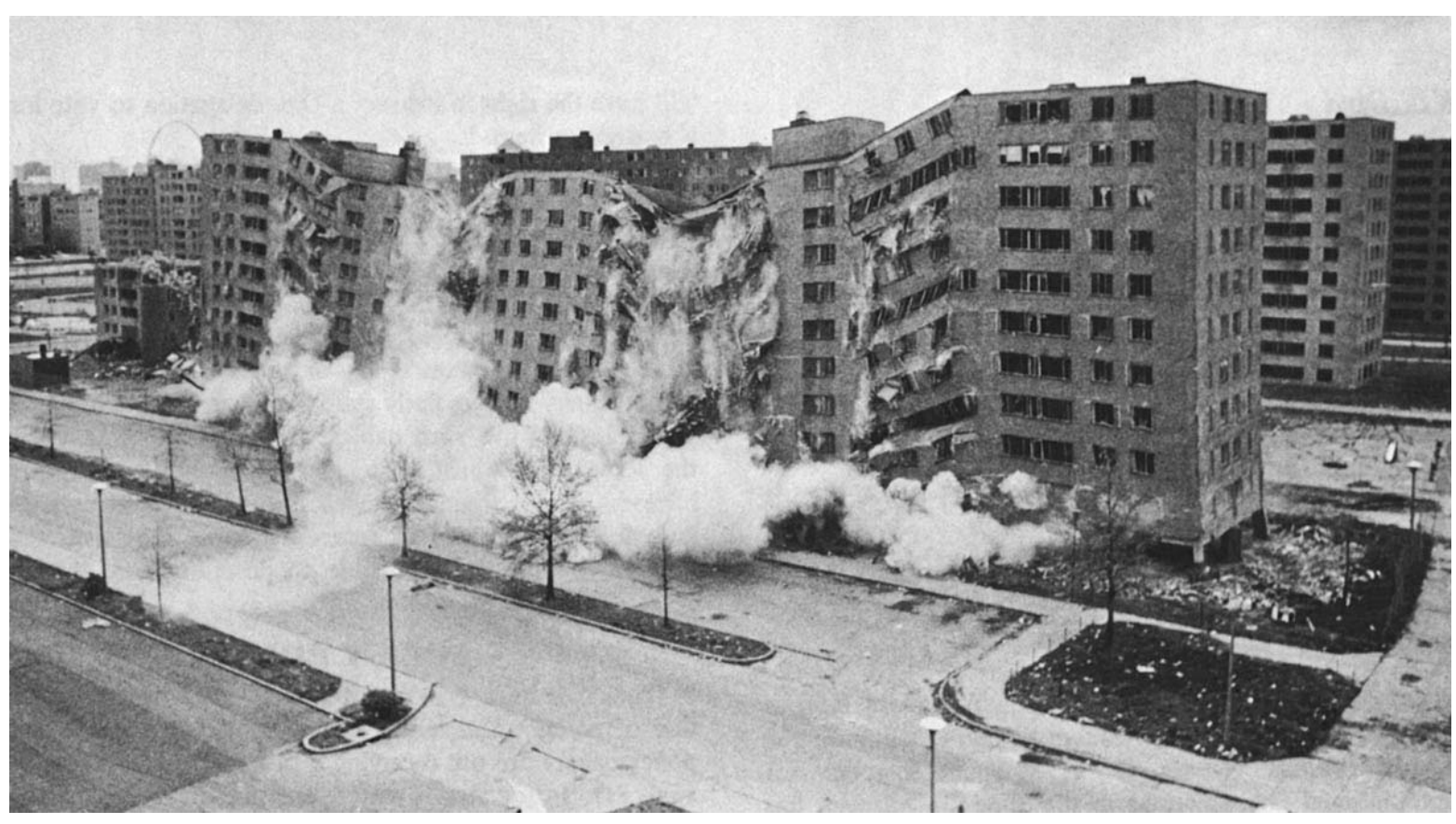

Demolição do conjunto habitacional Pruitt-Igoe, em Saint Louis, em 15 de julho de 1972. Imagem acessada de www.aliciapatterson.org/APF0801/Cohn/Cohn.html em 14 de abril de 2008.

A necessidade de rápida produção internamente ao processo de reconstrução do pós-guerra gerou grandes conjuntos, com algumas dezenas de milhares de habitantes, distantes dos centros, produzindo uma situação de segregação urbana e alienação em escala equivalente nas populações aí residentes. Produzidos sob as premissas corbusianas para a Ville Radieuse: habitar, circular, trabalhar e divertir-se (nas horas livres), os grandes conjuntos, principalmente na França, acabaram por concentrar grande parte de seus problemas sociais, sobretudo com o correr da substituição dos moradores originalmente franceses por imigrantes pobres do norte da África. Com a elevação dos índices de desemprego atingindo, especialmente, estas populações, os grandes conjuntos explodiram, numa série de revoltas. "Com a ausência do fator 'trabalho', os outros princípios (corbusianos) perdem o sentido e estes conjuntos habitacionais tornaram-se focos de turbulência social"97. Em lugar de evitar a revolução, como imaginava Le Corbusier, a arquitetura moderna propiciava seu meio de cultura.

97 Deutsche Welle. Arquitetura ou Revolução? 15 de novembro de 2005. A matéria em questão trata da explosão social na periferia (banlieues) de Paris, cujo estopim foi a morte de dois jovens moradores do Grand Ensemble de Clichy-sous-Bois em 27 de outubro de 2005. 


\subsection{Os programas públicos de reabilitação dos grandes conjuntos habitacionais na Europa}

Desde a década de 1960 o resultado da política de produção habitacional massiva sob a forma de grandes conjuntos vem sendo posto em discussão, com intensos questionamentos a respeito da baixa qualidade urbanística encontrada nesses espaços, bem como a segregação imposta às populações aí residentes.

As discussões iniciais acabaram por imputar a dois grandes aspectos principais os problemas verificados nos espaços produzidos sob a forma de grandes conjuntos habitacionais: aqueles relacionados aos locais de implantação, representados por áreas subequipadas, com baixa acessibilidade e distantes dos postos de trabalho e dos centros administrativos das cidades existentes; e aqueles relacionados às tipologias urbanas e arquitetônicas que embasaram a concepção dos conjuntos, diretamente vinculadas aos cânones do Movimento Moderno ${ }^{98}$.

Algumas das primeiras iniciativas visando enfrentar os problemas dos grandes conjuntos consistiram em soluções eminentemente "estéticas". Como no caso já visto do grand ensemble de Val d'Yerres, a proposta de um desenho urbano diferenciado, valorizando a paisagem natural e buscando a diversidade tipológica, não resultou em melhorias socioambientais significativas.

Paralelamente, diversas ações foram desenvolvidas, sobretudo a partir dos anos 1980, a fim de reverter o quadro de subequipamento dos conjuntos - especialmente no caso francês - de modo a implantar ou viabilizar estabelecimentos comerciais, serviços sociais e equipamentos públicos. Como se viu, nos diversos distúrbios ocorridos nos grands ensembles estes se converteram nos primeiros e preferenciais alvos de depredações e saques.

Como lembra SLOMIANSKY, essa correlação entre a degradação ambiental e social dos conjuntos habitacionais e sua tipologia arquitetônica e urbanística, que orientou as incipientes propostas de reabilitação, foram postas à prova quando, no início dos anos 1990, constatou-se a permanência - quando não o agravamento - dessas condições de degradação ${ }^{99}$. Contudo, faz-se necessário lançar luz sobre as mudanças radicais do contexto político, econômico e social que marcaram esse momento. Mudanças estas que tiveram impactos muito mais profundos que singelas intervenções pontuais não seriam capazes de mascarar, muito menos de resolver questões de maior monta.

\footnotetext{
${ }^{98}$ Cf. SLOMIANSKY, Adriana Paula. Op. Cit., 2002, p. 36.

${ }^{99}$ Cf. SLOMIANSKY, Adriana Paula. Op. Cit., 2002, p. 38.
} 
Verdadeiramente, essas ações acabaram por expor as contradições que permeavam esses espaços.

Nesse ínterim - entre fins dos anos 1970 e a década de 1990 - dois processos de certa forma inter-relacionados, ocorreram - nesse caso especificamente na França, mas o processo é comum a outros países - de modo a alterar o contexto social e político dos grandes conjuntos franceses: a chegada de grandes levas de imigrantes oriundos do norte da África, com a saída dos moradores franceses originais, e a escalada das políticas neoliberais. Assim, essa aparente contradição apontada por SLOMIANSKY decorre do fato de que os problemas que realmente afetam o cotidiano dos grands ensembles não devem ser buscados ali - ou apenas ali - mas na construção social dessa realidade ${ }^{100}$.

Não se quer dizer que o "desenho" não tenha um papel (relevante) na produção e no possível enfrentamento - da segregação e da alienação nesses espaços. O que se coloca é que a complexidade de tal questão não pode ser resumida ao enfrentamento apenas através do recorte urbanístico e arquitetônico ${ }^{101}$. Para BOURDIEU, o problema nos grandes conjuntos é social, e teve sua gênese nos anos 1970, a partir da conversão do Estado a uma visão neoliberal, em que se substituiu um auxílio público ao setor imobiliário por uma "ajuda individualizada". Essa alteração é que teria sido a "responsável pelo aparecimento dos lugares de relegação nos quais, sob o efeito da crise econômica e do desemprego, se encontram concentradas as populações mais desfavorecidas" ${ }^{102}$. Assim, a decadência e degradação dos grands ensembles estariam efetivamente relacionadas à "demolição da idéia de serviço público" que se seguiu ao triunfo do ideário neoliberal a partir dos anos 1970 e $1980^{103}$.

Entretanto, este trabalho trata, justamente, das possibilidades não apenas do "desenho" propriamente dito, mas da constituição e efetividade de políticas públicas voltadas à reabilitação dos grandes conjuntos de modo a garantir não apenas o direito à moradia, mas, também, o "direito à cidade".

\footnotetext{
${ }^{100}$ Cf. BOURDIEU, Pierre. A demissão do Estado in BOURDIEU, Pierre (Coord.). Op. Cit., 2007, p. 215.

101 Bourdieu coloca essa questão ao tratar da precária divisão em "disciplinas" estanques, que fragmentam o objeto de estudo em "cortes totalmente inadequados", aos quais escapa a "complexidade dos fatos". Cf. BOURDIEU, Pierre. Op. Cit., 2007, p. 215, Nota 1. Da mesma forma Lefebvre também levanta o problema e a inadequação de se estudar o fenômeno urbano através das ciências parcelares. LEFEBVRE, Henri. A Revolução Urbana. Belo Horizonte: UFMG, 1999.

${ }^{102}$ BOURDIEU, Pierre. Op. Cit., 2007, p. 216.

${ }^{103}$ Cf. BOURDIEU, Pierre. Op. Cit., 2007, p. 217.
} 


\subsubsection{A Reabilitação na Espanha}

Não houve, na Espanha, uma política generalizada voltada à reabilitação dos conjuntos habitacionais; entretanto, algumas ações pontuais, especificamente direcionadas a determinados polígonos de vivienda, configuram-se em exemplos bastante interessantes acerca da atuação e dos meios utilizados para a recuperação dessas áreas.

Já em fins dos anos 1960 os problemas latentes nos conjuntos produzidos desde a década anterior vieram à tona. A produção habitacional do período, marcada pela busca da redução dos custos e da maximização da quantidade de unidades produzidas resultou em espaços desqualificados, desequipados e desconectados da malha urbana. A baixa qualidade dos materiais empregados em sua construção acarretou em que, rapidamente, os polígonos de vivienda apresentassem uma profunda deterioração dos edifícios, cujos custos de manutenção passaram a superar, em muito, o valor das quotas pagas pelos moradores ao organismo público, a $\mathrm{OSH}$. As tentativas da $\mathrm{OSH}$ em, num primeiro momento, elevar o valor dos aluguéis a fim de cobrir seus elevados custos de conservação e manutenção e, posteriormente, transferir esses imóveis (e seus custos de conservação) a seus ocupantes, teve como resultado a mobilização dos moradores dos conjuntos em "associações de moradores", que passaram a pressionar a OSH com paralisações no pagamento dos aluguéis. Essa mobilização forçou o Ministério da Habitação espanhol, em 1973, a constituir uma dotação orçamentária específica para reformas nas edificações dos conjuntos, definidas como Proyectos de Reparaciones. A partir da redemocratização, em 1975, as demandas sociais represadas após quase quatro décadas de autoritarismo franquista vieram à tona e, especialmente no campo da habitação, cobraram uma resposta do Estado. O movimento social ganhou força, e passou a reivindicar uma série de melhorias nesses bairros, que podem ser sintetizadas em duas linhas principais: a luta por melhorias nas moradias, equipamentos e infra-estrutura; e pela remodelação e o direito de permanência nos bairros ${ }^{104}$.

A baixíssima qualidade das edificações e dos conjuntos urbanos representados pelos polígonos de vivienda demandou grandes investimentos em manutenção e reparações. Entre 1976 e 1984 foram gastos 9 bilhões de pesetas nos conjuntos espanhóis basicamente na recuperação de suas condições originais ou na manutenção ordinária;

${ }^{104}$ Cf. MOYA GONZALEZ, Luis. Op. Cit., 1983, p. 111 apud BLOS, Dorotea. Op. Cit., 1999, p. 127-8. 
apenas 5\% desse valor se referiu a ações de melhoria em relação às suas condições de segurança e conforto ${ }^{105}$.

Em Madri as reivindicações dos movimentos sociais por melhorias urbanísticas levaram à instituição, a partir de 1979, de um programa intitulado Remodelación de Barrios, de intervenções urbanas de urgência em 30 bairros da cidade. Esse programa consistiu, basicamente, na demolição e reconstrução de moradias deterioradas, pontos comerciais e equipamentos públicos na periferia consolidada da cidade de Madri, atingindo uma área de cerca de 800 hectares e 38.590 moradias, com um investimento inicial previsto em 200 bilhões de pesetas em 1985. De modo geral três tipos de bairros - de acordo com seu processo constitutivo - foram atendidos por esse programa: os núcleos formados nos anos 1950 e 60 por meio da autoconstrução das moradias; os bairros de Promoción Oficial, ou seja, os conjuntos habitacionais promovidos pelo Estado espanhol com vistas à erradicação de favelas ou como alojamento às populações migrantes recém-chegadas a Madri; e as intervenções em zonas de sub-habitação dispersas pela cidade ${ }^{106}$.

Um dos pontos fundamentais do processo de remodelação de bairros populares de Madri foi a busca pela manutenção dessas populações de baixa renda nos locais onde já residiam, o que foi conquistado por meio da atuação das associações de moradores locais (asociaciones de vecinos). As operações de remodelação, pela própria precariedade das condições urbanísticas e das edificações existentes, as quais, muita vezes, não apresentavam possibilidade de aproveitamento e recuperação, pautou-se pela demolição do parque construído e sua substituição por novas estruturas urbanas e habitacionais.

As demandas das associações de moradores do chamado movimiento vecinal centraram-se na questão das responsabilidades do Estado espanhol para com essas populações residentes em áreas precárias, buscando o reconhecimento da "dívida social" de que eram credoras, por terem servido de mão de obra barata nos tempos de desenvolvimento econômico, sem terem recebido investimentos públicos em suas áreas de residência. Além disso, as associações de moradores exigiam a permanência de todos os moradores nas áreas objeto de intervenção, uma vez que o longo tempo decorrido desde a implantação dos bairros acarretou em que o crescimento da metrópole de Madri tenha tornado a localização desses bairros atrativa aos interesses do mercado imobiliário. Dessa

\footnotetext{
${ }^{105}$ BLOS utiliza esses valores em referência à peseta de 1984. Cf. BLOS, Dorotea. Op. Cit., 1999, p. 250. Este valor equivaleria a aproximadamente 55 milhões de dólares americanos, segundo o valor do câmbio de agosto de 1984. Não está considerada, aqui, a inflação em dólar do período.

${ }^{106}$ Cf. VINUESA, Julio, SÁNCHEZ-FAYOS, Teresa e OLIETE, Ana. La Operación de Remodelación de Barrios en Madrid in Revista Ciudad y Territorio, No 68, abril-junio 1986, p. 71-2. Este valor de 200 bilhões de pesetas de 1985 equivaliam a cerca de 1,1 bilhão de dólares americanos conforme a taxa de câmbio de fevereiro de 1985. Igualmente, os valores não consideram a inflação em dólar desde 1985.
} 
forma exigia-se a manutenção desses moradores nos locais que seriam inevitavelmente valorizados com a reabilitação. Além disso, o estado ruinoso dos conjuntos habitacionais promovidos pelo Estado demandava a urgente remodelação desses espaços ${ }^{107}$.

A Orden Comunicada de 24 de maio de 1979 definiu os bairros objeto da remodelação e os pontos fundamentais da operação: o reconhecimento da "dívida social" e o compromisso do Estado na reabilitação desses espaços; o direito ao realojamento no próprio bairro; o respeito ao regime de propriedade preexistente; a avaliação das antigas moradias, com pagamento de indenizações; a promoção direta; a implementação de um conjunto unificado de ações nos bairros objeto da operação; e o estabelecimento de condições especiais de financiamento. Os critérios estabelecidos para a definição de quais bairros seriam beneficiados por essas operações não foram aí explicitados, mas, aparentemente, tiveram relação direta com o grau de mobilização dos residentes em torno das associações de moradores mais bem organizadas e atuantes, o que explica a elevada proporção de conjuntos habitacionais dentre estes ${ }^{108}$. Dos trinta bairros inseridos na Orden Comunicada, catorze eram conjuntos habitacionais de promoção pública, que correspondiam a 15.736 unidades habitacionais em 201,8 hectares $^{109}$.

No Poblado Dirigido de Orcasitas, por exigência do próprio movimento de moradores, definiu-se pela manutenção das tipologias existentes no conjunto, de moradias unifamiliares e unidades em blocos de apartamentos. O ganho na área útil das unidades foi considerável, passando de 40 para $105 \mathrm{~m}^{2}$, em média. Contudo, a situação urbana permanece sem alterações, com os equipamentos situados nos limites do conjunto e os estabelecimentos comerciais instalados em galerias fechadas, mantendo a rigidez de usos anterior $^{110}$.

Da mesma forma, no caso do Poblado Dirigido San Blas $H$, a intervenção pautouse pela melhoria - considerável - nas condições das unidades, com o aumento da sua área útil que passou de $39 \mathrm{~m}^{2}$ para cerca $80 \mathrm{~m}^{2}$. Entretanto, as duas intervenções, se qualificam o uso residencial, relevam os problemas vinculados à monofuncionalidade desses espaços e aqueles relativos à integração desses tecidos à cidade à sua volta. Os projetos implantados nessa primeira fase do programa de Remodelação de Bairros de Madri

\footnotetext{
${ }^{107}$ Cf. VINUESA, Julio, et al. Op. Cit., 1986, p. 76.

${ }^{108}$ Cf. VINUESA, Julio, et al. Op. Cit., 1986, p. 77-8.

${ }^{109}$ Cf. VINUESA, Julio, et al. Op. Cit., 1986, p. 74. Os conjuntos habitacionais incluídos na primeira fase da operação de Remodelação de Bairros Populares de Madri foram: Los Cármenes/Caño Roto, San Fermín, San Blas I, Poblado Dirigido de San Blas H, Pan Bendito, Zofio, ORCASUR, Canillejas, UVA Vallecas, UVA Villaverde, Poblado Mínimo de Vallecas, Santa Ana Fuencarral, Poblado Dirigido de Orcasitas e Almendrales.
}

${ }^{110}$ Cf. BLOS, Dorotea. Op. Cit., 1999, p. 380. 
enfocaram, sobretudo, a melhoria das condições de habitabilidade, sem levar em conta as possibilidades de integração física e funcional desses territórios à cidade ${ }^{111}$.

O Poblado de Absorción General Ricardos não constava deste primeiro bloco de bairros a passarem por intervenção. Conjunto habitacional construído na década de 1950 justamente para a remoção de um núcleo de favelas de Madri, apresentava várias das características presentes na produção que marcou os conjuntos da COHAB-SP: baixa qualidade ambiental e urbanística, subequipamento, ruptura com o tecido urbano do entorno, monofuncionalidade e monotonia tipológica.

Desde 1979 a população residente em General Ricardos reivindicava a inclusão do conjunto no programa de remodelação que se iniciava. No entanto, somente com a aprovação em 1985 do Plan General de Ordenación Urbana de Madrid se definiu a necessidade de uma intervenção de maior monta para a área, determinando a elaboração de um PERI - Plan Especial de Reforma Interior, onde se definiu pela reestruturação total do conjunto, devido ao avançado estado de deterioração física dos edifícios (sendo que um deles apresentava risco iminente e teve que ser demolido de imediato), a exigüidade das áreas dos apartamentos e a inadequação do programa anterior ${ }^{112}$.

O PERI desenvolvido para o conjunto constatou que a reabilitação dos edifícios implicaria em obras com custo mais elevado que a demolição e reconstrução de todo o bairro, sendo que o resultado ainda teria uma qualidade muito baixa. Optou-se, então, pela demolição de trinta edifícios laminares de 4 e 5 andares, implantados conforme os pressupostos do urbanismo racionalista das décadas de 1950 e 1960. A demolição e reconstrução do conjunto foi gradual, tendo início em maio de 1986, mobilizando partes da população moradora para abrigos provisórios (fillods) no próprio local, onde aguardavam de 18 a 24 meses até a conclusão de seu novo prédio. Das 950 famílias desalojadas pelas obras, 662 puderam ser realojadas internamente ao novo conjunto, enquanto as demais foram realocadas em conjuntos nessa mesma região da cidade ${ }^{113}$.

Como nos bairros estudados anteriormente, General Ricardos tampouco rompe com a monofuncionalidade dos conjuntos de Madri; contudo, realiza uma importante intervenção no sentido de se integrar fisicamente à cidade à sua volta. O PERI propôs a reestruturação do conjunto com a construção de novos edifícios conformando nove quadras fechadas, seguindo o tradicional urbanismo de Madri sob a forma de manzanas,

\footnotetext{
${ }^{111}$ Cf. BLOS, Dorotea. Op. Cit., 1999, p. 385-6.

112 Cf. NEGRELOS, Eulalia Portela. Op. Cit., 1998, p. 150.

${ }^{113}$ Cf. NEGRELOS, Eulalia Portela. Op. Cit., 1998, p. 148-151.
} 
assim como mais duas quadras para a implantação de equipamentos públicos e uma para um "parque urbano". Buscava-se, assim, a partir desse plano

o planejamento das áreas residenciais de nova construção de forma diferente de como se realizou em épocas anteriores em que as condições conjunturais socioeconômicas eram outras, e nas quais primavam, de alguma maneira, mais as questões quantitativas que as qualitativas, e portanto mais em consonância com a situação atual que prima pela qualidade de vida e onde o papel dos usuários se faz mais protagonista. (...) O critério geral deste trabalho (o PERI) é tentar, dentro do âmbito limitado da própria atuação, 'fazer cidade'. (...) Dentro desse objetivo de 'fazer cidade' há que considerar não somente a própria morfologia da área sobre a que se atua senão também e com não menor intenção a incorporação 'de e com' a cidade contígua, na medida em que isto seja possível. (...) Nessa busca de 'fazer cidade', e dentro do espaço público, tem singular importância o traçado viário, tanto pelo seu peso funcional que é muito estruturador da área, quanto pelo poder formal e referencial que o viário tem significado no conceito tradicional de cidade, ao menos em nossas coordenadas culturais e ambientais (...) $)^{114}$

Foi resolvido um dos grandes conflitos encontrados anteriormente: a ocupação das escassas áreas livres como estacionamento de automóveis. O novo projeto previu áreas reservadas aos veículos dos moradores nas áreas particulares e liberou as áreas livres e passeios para os pedestres ${ }^{115}$.

Toda a área objeto da intervenção tinha como proprietário o INV - Instituto Nacional de la Vivienda, que promoveu a construção. Após a urbanização o sistema viário, áreas verdes e livres foram cedidos à Prefeitura de Madrid, e o terreno desmembrado em uma área do INV, outra do IVIMA - Instituto de Vivenda de Madrid e outra cedida à Igreja Católica para implantação de um seu equipamento.

As áreas internas às manzanas constituem-se em áreas condominiais, e as unidades habitacionais são de propriedade do IVIMA, sendo seu acesso realizado por meio de aluguel. Após sete anos de aluguel os moradores podem exercer seu direito de compra do apartamento ou seguir vivendo no aluguel, sendo que os antigos moradores tiveram o aluguel dos primeiros quatro anos reduzido à metade em função de terem abandonado suas antigas moradias. Por meio de diversos outros mecanismos de subsídio estabelecidos em função da renda e composição familiar do morador se poderia atingir até $95 \%$ de desconto no valor desse aluguel ${ }^{116}$.

\footnotetext{
${ }^{114}$ PERI - Plan Especial de Reforma Interior, 1986, p. 42-3 apud NEGRELOS, Eulalia Portela. Op. Cit., 1998, p. 152.

${ }^{115}$ Cf. NEGRELOS, Eulalia Portela. Op. Cit., 1998, p. 148-151.

${ }^{116}$ Cf. NEGRELOS, Eulalia Portela. Op. Cit., 1998, p. 156-7.
} 

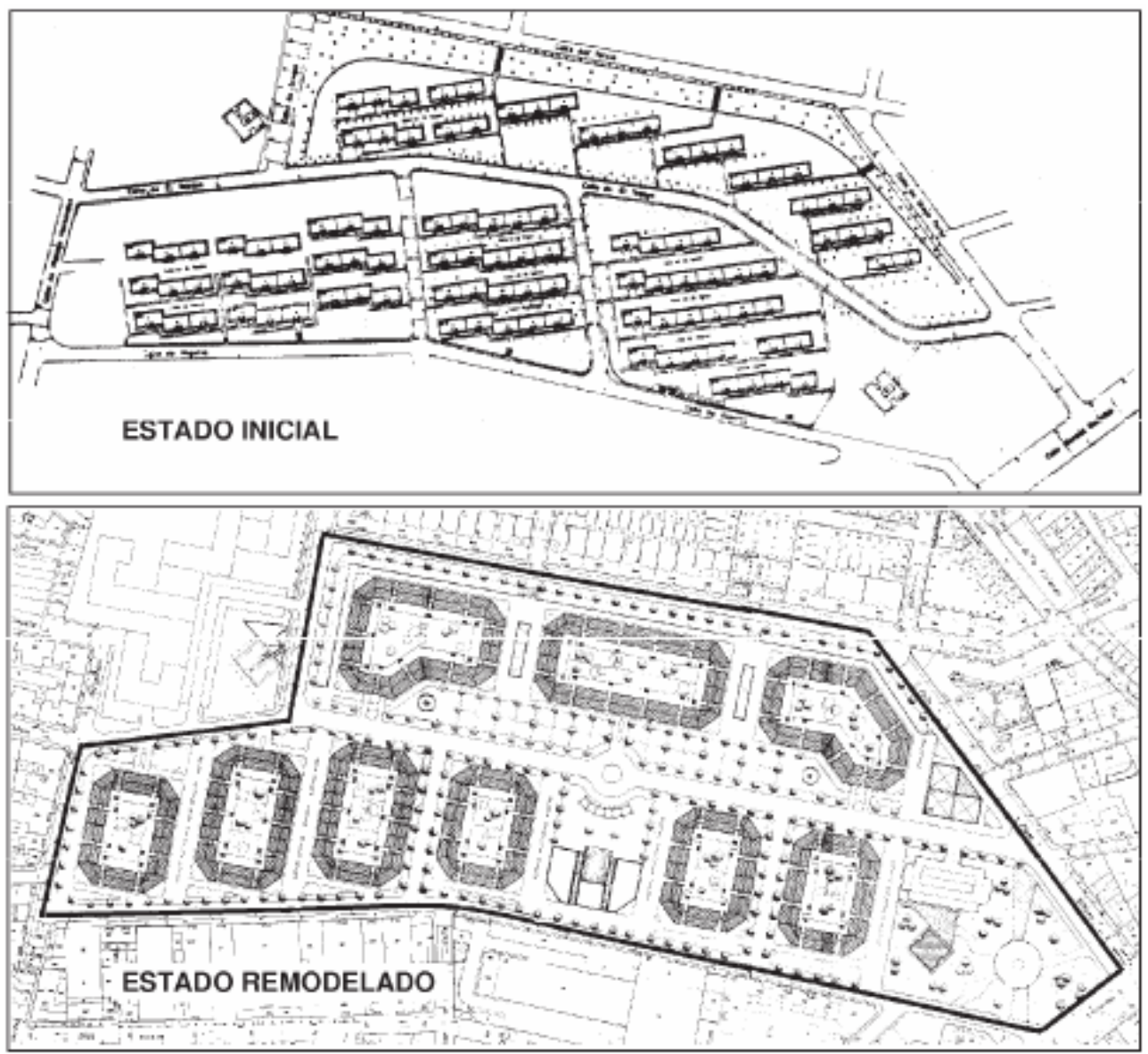

No alto, situação original do conjunto "General Ricardos". Abaixo, projeto de remodelação do conjunto "General Ricardos" proposto pelo PERI - Plan Especial de Reforma Interior. Os blocos laminares originais são demolidos e substituídos por blocos fechados sob a forma das tradicionais manzanas. A reorganização do sistema viário e a nova tipologia proposta para os edifícios integra fisicamente o conjunto ao entorno consolidado. Imagens extraídas de BLOS, Dorotea. Op. Cit., 1999, p. 372.

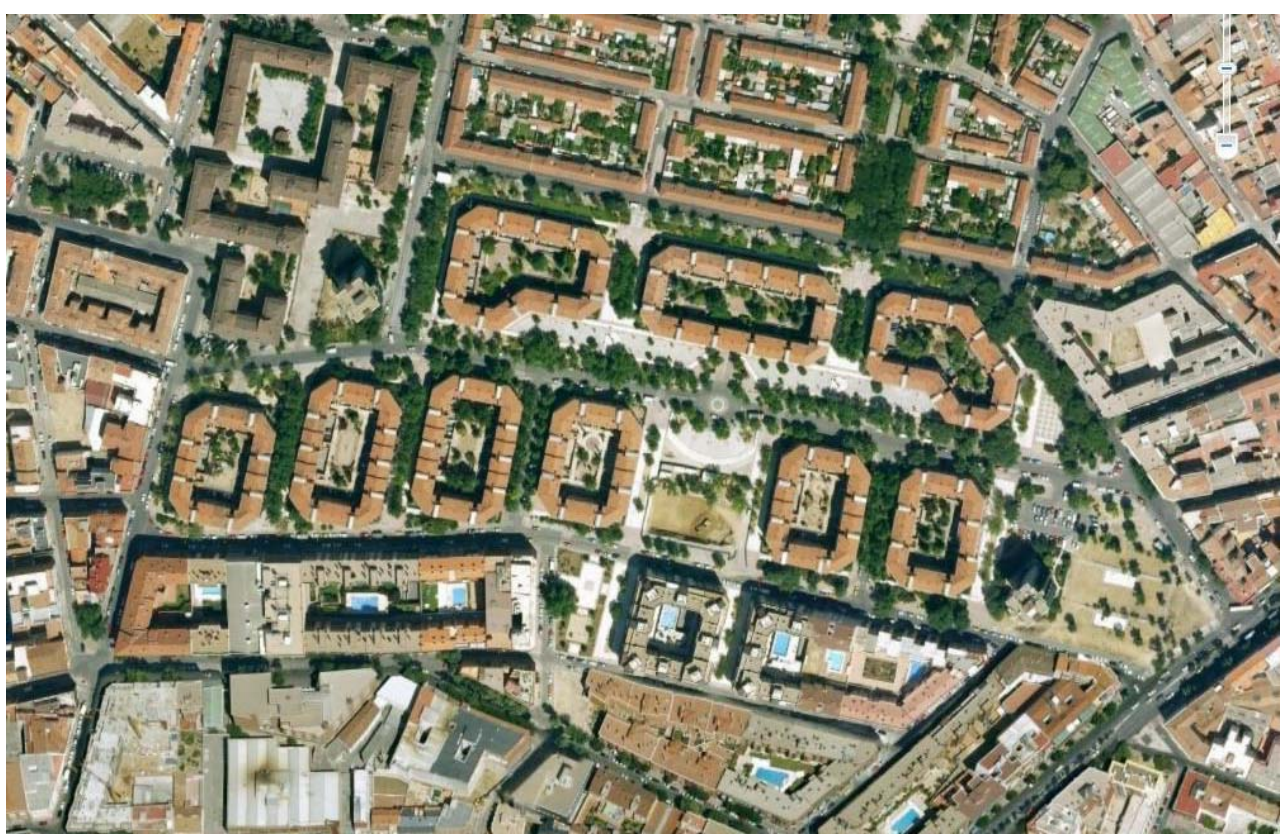

Vista do conjunto "General Ricardos" após a conclusão das obras de remodelação. Imagem de 3 de agosto de 2007 extraída do Google Earth em 4 de novembro de 2008. 


\subsubsection{A Reabilitação na França}

Os programas e ações voltados à reabilitação dos conjuntos habitacionais franceses apresentam especificidades em relação à anteriormente relatada experiência espanhola. No caso francês estes foram estruturados em programas de maior envergadura e ambição, procurando intervir de forma mais ampla e integrada em contextos urbanos mais complexos.

As primeiras iniciativas nesse campo remontam ao período dos anos 1970 marcado pelos dois choques do petróleo, em que a elevação do custo desse insumo altamente relevante no aquecimento levou a uma série de ações de reforma nas edificações, voltadas a aperfeiçoar o isolamento térmico dos prédios, melhorando a eficiência energética dos mesmos e produzindo economias no consumo de combustível.

O primeiro programa voltado especificamente à reabilitação dos conjuntos periféricos franceses foi o HVS - Hábitat e Vida Social (Habitat et Vie Sociale), cujas operações tiveram início em 1977 e consistiam, em linhas gerais, em iniciativas de recuperação das edificações, implantação de equipamentos, intervenções de requalificação dos espaços exteriores e ações de animação social dos bairros por meio de programas e atividades culturais, iniciativas de caráter bastante pontual. A importância das operações HVS reside mais no fato de terem representado uma mudança de mentalidade na atuação do Estado nos grandes conjuntos franceses do que por seus resultados efetivos na reabilitação desses espaços, em que pela primeira vez se reconhecia a degradação acentuada e progressiva - dos grands ensembles, bem como a necessidade urgente de intervenção. Interessante como alguns conjuntos passaram por ações de reabilitação desde essas primeiras experiências e ao longo das décadas seguintes ${ }^{117}$.

Entretanto, como já apresentado anteriormente, os problemas dos grands ensembles iam muito além da diminuição dos gastos com o aquecimento, melhorias físicas pontuais ou animação por meio de eventos culturais; a grave crise econômica que se seguiu a esse período atingiu em cheio esses territórios. Os altos índices de desemprego, de jovens em crise escolar, de imigrantes não-europeus, transformavam os conjuntos no meio de cultura da crise social que não tardaria a se abater sobre a banlieue.

A partir dos confrontos ocorridos em Les Minguettes em 1981 a intervenção nos grandes conjuntos de forma a recuperá-los ambiental e socialmente tornou-se prioridade do Estado francês, que passou a procurar enfrentar os graves problemas que persistiam

${ }^{117}$ Cf. BLOS, Dorotea. Op. Cit., 1999, p. 287, 453-4. Os conjuntos atendidos nas operações HVS e que também foram objeto de intervenção nos programas subsequentes foram o Grand Ensemble de OrlyChoisy e La Grande Borne. 
nesses territórios por meio de ações específicas e integradas. Nesse ano as condições de deterioração e precariedade social dos "bairros em dificuldade" podiam ser sintetizadas em:

- Segregação social, multiplicada pela concentração de famílias em situação social e econômica difícil, e em especial de famílias de origem estrangeira.

- Rejeição desses bairros pelo resto da cidade.

- Alta porcentagem de jovens e, sobretudo de adolescentes nascidos nesses bairros nos anos sessenta.

- Insuficiência e inadequação dos meios de gestão (manutenção, segurança...), o que conduzia a uma degradação acelerada dos equipamentos e dos espaços públicos ${ }^{118}$.

Para tanto foram instituídos diversos grupos de trabalho interministeriais, a partir de uma visão global acerca dos problemas a serem enfrentados. Dentre essas iniciativas interessa-nos, sobretudo, o CNDSQ - Comissão Nacional para o Desenvolvimento Social dos Bairros (Commission Nationale pour le Développement Social des Quartiers), a qual congregava políticos, servidores públicos, os organismos HLM, dirigentes de associações, sindicalistas, acadêmicos e pesquisadores, em busca de soluções para os problemas da periferia francesa ${ }^{119}$.

O CNDSQ elabora e conduz a implementação das operações DSQ Desenvolvimento Social dos Bairros (Développement Social des Quartiers), ao longo dos anos de 1982 e 1983, com ações em 22 bairros-piloto. A seu encargo coube coordenar a ação interministerial e administrar o orçamento e a liberação de recursos para as intervenções. Esse processo encontrou diversos percalços devido, principalmente, às dificuldades de gestão desses programas representadas pelo distanciamento entre a coordenação altamente centralizada na comissão nacional e sua implementação em âmbito local nas municipalidades.

Essa política pública de "desenvolvimento social dos bairros" estruturou-se sobre quatro princípios fundamentais:

- Atuar tanto sobre as causas da degradação quanto sobre a degradação em si, considerando, além dos problemas da moradia, o conjunto de problemas da vida cotidiana dos habitantes desses bairros, como a educação, inserção social e profissional, emprego, desenvolvimento, cultura, saúde, esporte.

- Confiar à administração local a responsabilidade política do programa, tanto em sua concepção quanto em sua gestão.

- Fazer dos habitantes, e a seus representantes através das associações, agentes da mudança, proporcionando-lhes os meios institucionais e materiais para essa participação.

\footnotetext{
${ }^{118}$ HARBURGER, Sylvie. El Programa Francés de Desarrollo Social de los Barrios in Revista Ciudad y Territorio, No 72/73, abril-septiembre 1987, p. 37.

${ }^{119}$ Cf. HARBURGER, Sylvie. Op. Cit., 1987, p. 38.
} 
- Garantir uma solidariedade nacional através de financiamentos excepcionais, mas, sobretudo, através de uma mobilização coordenada dos serviços estatais in situ (educação, justiça, policiamento, ação social e cultural...) Este é o corolário do primeiro princípio ${ }^{120}$.

Ao longo dos anos 1980 a França passou por um processo de descentralização administrativa que resultou na transferência de responsabilidades e competências às regiões do país. Com isso foram reestruturados os programas de requalificação dos conjuntos por meio de contratos firmados sob a forma de parcerias entre as diferentes instâncias governamentais, com o intuito de elaborarem e implementarem projetos e ações de interesse comum. Essa reformulação administrativa implicou na formulação de "contratos de plano" entre as diferentes instâncias governamentais, com objetivos, prazos e delimitação territorial específicos.

Para o período compreendido entre os anos de 1984 e 1988 foi elaborado o IX Plan - Viver Melhor na Cidade entre o Estado nacional e dezoito regiões, priorizando as intervenções de "desenvolvimento social dos bairros". A operacionalização financeira do plano consistia na articulação entre as demandas presentes em cada bairro - firmadas nos contratos - e as disponibilidades orçamentárias de dez diferentes ministérios, cujos recursos eram canalizados para a execução dos objetivos das operações DSQ. Sua implementação era levada a cabo numa parceria entre o Estado nacional e a municipalidade, ficando esta encarregada da execução das obras por meio de uma Comissão Local, composta por todos os atores envolvidos, e responsável pela definição das linhas gerais do projeto e por sua implantação. A municipalidade devia, ainda, indicar um "chefe de projeto" para cada operação, auxiliado por uma equipe executiva. Regionalmente, instaurava-se uma Comissão responsável pelo acompanhamento do Plano, co-presidida pelo Comissário Regional da República e pelo presidente do Conselho Regional $^{121}$.

Dos 22 bairros-piloto originais passou-se, nesse momento, a 148 bairros DSQ objetos de intervenções de requalificação, abarcando 434.394 moradias, totalizando 1.366.046 habitantes em 150 cidades diferentes. Os organismos de HLM, especialmente, tinham grande interesse nesse programa pela possibilidade de terem acesso a linhas de financiamento para recuperar seu patrimônio degradado. O esforço de requalificação produziu a reforma, no período de 1984-88, por meio de 150 organismos de HLM, de 170.000 moradias, correspondendo a $40 \%$ do parque habitacional dos 148 bairros objeto

\footnotetext{
${ }^{120}$ HARBURGER, Sylvie. Op. Cit., 1987, p. 38.

${ }^{121}$ Cf. HARBURGER, Sylvie. Op. Cit., 1987, p. 38.
} 
da ação ${ }^{122}$. Diferentemente da Espanha, onde as intervenções de requalificação de conjuntos acabaram por se restringir, quase que na totalidade dos casos, apenas ao perímetro ocupado por estes, na França essas ações foram se ampliando na direção de encarar e enfrentar a complexidade das relações entre a banlieue e a cidade como um todo.

No grande conjunto de Clichy-sous-Bois/Montfermeil, objeto de um contrato DSQ nesse IX Plan foram previstas, entre outras, a compra de alguns edifícios pelo Office Départamental HLM ou pela municipalidade para permitir sua reabilitação; aquisição de unidades para permitir o realojamento de moradores de um edifício cuja demolição estava prevista; realização de Concurso de Urbanismo com vistas ao reordenamento urbano do conjunto, à redinamização econômica e social, à reabilitação dos edifícios e dos espaços exteriores dos conjuntos; e o fomento à reabilitação dos edifícios privados ${ }^{123}$.

Conjuntos que já haviam passado por intervenções desde a criação das operações HVS, La Grande Borne e Orly-Choisy-le-Roi também tiveram realizados contratos DSQ no IX Plan. O primeiro teve previsto, nesse contrato, a reabilitação das moradias; a reorganização da circulação e dos estacionamentos; a melhoria de equipamentos urbanos como ginásio esportivo, piscina, escola e a criação de um centro social com biblioteca; implantação de um zoneamento especial para fomentar a atividade econômica com vistas ao incentivo à geração de empregos; investimentos para enfrentar a situação de fracasso escolar dos moradores jovens; reforço à segurança; e melhoria nos transportes. Para o grand ensemble de Orly-Choisy foram previstos a reabilitação das moradias e a criação de unidades habitacionais de maiores dimensões nos térreos para as famílias numerosas; implantação de um escritório local do organismo HLM; reordenação dos espaços livres públicos; implantação de uma sala de música, duas salas de jogos e uma "Casa da Infância"; subvenção de "Banlieues 89"124 para a criação de um projeto de ligação entre a estação ferroviária de Les Saules e o conjunto, com a construção de

\footnotetext{
122 Cf. BLOS, Dorotea. Op. Cit., 1999, p. 292.

${ }^{123}$ Cf. BLOS, Dorotea. Op. Cit., 1999, p. 429.

124 O programa "Banlieues 89" foi criado, em fins de 1983, com o intuito de responder a demandas ou problemas pontuais, sobretudo aqueles relacionados à integração física dos subúrbios e seu entorno, por meio de intervenções de requalificação urbanística voltadas à melhoria dos aspectos cotidianos da vida nos bairros periféricos. Isto seria viabilizado a partir do investimento em centros comerciais, áreas de lazer, melhorias nos corredores viários, intervenções em corredores ferroviários que causavam grandes impactos e a ruptura do tecido urbano nos bairros de periferia, dentre outros. Com esse objetivo buscou-se intervir na constituição e fortalecimento das centralidades nas regiões suburbanas e na ruptura da rigidez dos grandes conjuntos, por meio de intervenções urbanísticas e arquitetônicas que reintroduzissem nesses espaços a "complexidade" e a "multiplicidade" presentes na "cidade histórica". Cf. CASTRO, Roland. Suburbios 89: una Gran Apuesta in Revista Ciudad y Territorio, № 72/73, abril-septiembre 1987, p. 27 a 35.
} 
moradias e equipamentos; implantação do Centro Comercial Leclerc para fomentar a criação de empregos; e o projeto de criação de um novo centro urbano para conectar o conjunto com o centro urbano de Orly - ZAC du Nouvelet ${ }^{125}$.

No X Plan atendeu-se um total de 407 bairros, sendo 271 "contratos DSQ", ao mesmo tempo em que se instituíram abordagens urbanas mais amplas, como os "contratos de cidade" - contratos DSU - Développement Social Urbain - e o plano de recuperação das antigas cidades industriais decadentes do nordeste francês ${ }^{126}$.

O grand ensemble de Orly-Choisy foi contemplado no $X$ Plan com um novo contrato DSQ, em que se previu a reabilitação de edifícios; um projeto de reestruturação urbana no bairro Calmettes-million; e a melhoria da circulação e das vias internas do conjunto, facilitando o acesso aos equipamentos e escolas. Já o conjunto de La Grande Borne foi contemplado nesse plano com um contrato DSU. Como já mencionado, este tipo de contrato apresentava um enfoque mais amplo e uma abrangência de ação que ultrapassava os limites físicos do conjunto. Foram previstos nesse contrato a reabilitação das moradias, promovendo a reestruturação interna de algumas delas com vistas a sua redução; a intervenção sobre as áreas exteriores aos prédios; a criação de um Observatório de População, bem como a melhoria na capacidade de intervenção do escritório local do organismo HLM; criação de um escritório de manutenção do bairro; projeto paisagístico para cerca de 60 hectares de áreas livres dentro do conjunto, constituindo um parque urbano para uso de toda a cidade, bem como ações mais pontuais em diversos "bairros" dentro do conjunto; e a elaboração de um projeto global para a cidade de Grigny, de modo a promover a integração entre os dois grandes conjuntos construídos no final dos anos 1960 - sobretudo La Grande Borne - e o centro antigo da cidade. Este projeto será a base para a definição de Grigny como uma das onze cidades escolhidas para o programa GPU - Grande Projeto Urbano (Grand Projet Urbain) no XI Plan $^{127}$.

Apesar dos significativos e crescentes recursos para a reabilitação mobilizados por esses planos e programas, os profundos problemas sociais que as populações aí residentes atravessavam emergiram novamente em 1990 em novos conflitos na periferia de Lyon, no caso já citado do bairro de Vaulx-en-Velin. Estes acontecimentos demonstraram, dramaticamente, que as ações destinadas a romper com a segregação dos conjuntos necessitariam uma abordagem que estendesse sua visão a toda a cidade, sendo

\footnotetext{
${ }^{125}$ Cf. BLOS, Dorotea. Op. Cit., 1999, p. 427-8.

${ }^{126}$ Cf. BLOS, Dorotea. Op. Cit., 1999, p. 290-8.

${ }^{127}$ Cf. BLOS, Dorotea. Op. Cit., 1999, p. 427-8.
} 
esta o objeto de ação necessária a romper com os guetos em que se tornavam os grands ensembles. Com este enfoque criou-se, nesse mesmo ano, o Ministério da Cidade francês, destinado a articular uma política nacional voltada à "luta contra a exclusão"128.

A partir do início dos anos 1990 a percepção de que o enfrentamento ao problema da exclusão e à persistente degradação dos grandes conjuntos não vinha surtindo efeito - o que os mantinha em permanente estado de ebulição, prestes a explodir - levou à formulação de políticas de reabilitação voltadas à cidade como um todo, compreendendo os problemas dos grands ensembles mais em sua relação com a cidade do que encerrados nos limites dos conjuntos.

Dessa forma as antigas ações, de caráter mais pontual e isoladas, como aquelas das Banlieues 89, foram substituídas por outras com enfoque mais amplo e baseadas na inserção dos grandes conjuntos nas áreas urbanas que os abrigam, bem como políticas de reabilitação coordenadas com as ações urbanas desenvolvidas regionalmente. Desse modo, deu-se início, em 1993, à formulação dos Grandes Projetos Urbanos, a serem financiados e implementados pelo XI Plan, entre os anos de 1994 e 1998.

Foram definidas onze cidades como prioridade nacional para a execução desse programa, tendo por princípios

uma forte intervenção urbana que combine uma série de ações que privilegiem a mescla moradia-emprego, a construção de novas moradias, a reestruturação dos centros comerciais e melhoria dos equipamentos, além do reordenamento dos espaços públicos, da rede viária e a melhoria da rede de transportes públicos ${ }^{129}$.

O XI Plan marca a alteração e reorientação das políticas de reabilitação em direção à problemática da cidade como um todo. São abandonados os contratos anteriores no formato DSQ, sendo firmados "contratos de cidade" com 185 municipalidades, especialmente aquelas localizadas em "aglomerações" urbanas.

As ações implementadas sob a forma de "contratos de cidade" pelo XI Plan estruturaram-se, por um lado, na melhoria dos equipamentos e serviços públicos de âmbito local, sob a forma de melhorias relacionadas à saúde, educação, cultura, segurança, entre outros e, por outro lado, na constituição de políticas de emprego, transportes ou habitação,

${ }^{128}$ Cf. BLOS, Dorotea. Op. Cit., 1999, p. 299.

${ }^{129}$ BLOS, Dorotea. Op. Cit., 1999, p. 448. As cidades selecionadas para os Grandes Projetos Urbanos do XI Plan foram Argenteuil, Alnay-sous-Bois, Clichy-Montfermeil, Genevilliers, Grigny, Mantes-la-Jolie, Marseille, Roubaix, Tourcing, Vaulx-en-Velin e Vénissieux, às quais se somou, posteriormente, SaintDenis. 
variando a intensidade de cada um desses enfoques de acordo com as especificidades de cada bairro objeto de intervenção ${ }^{130}$.
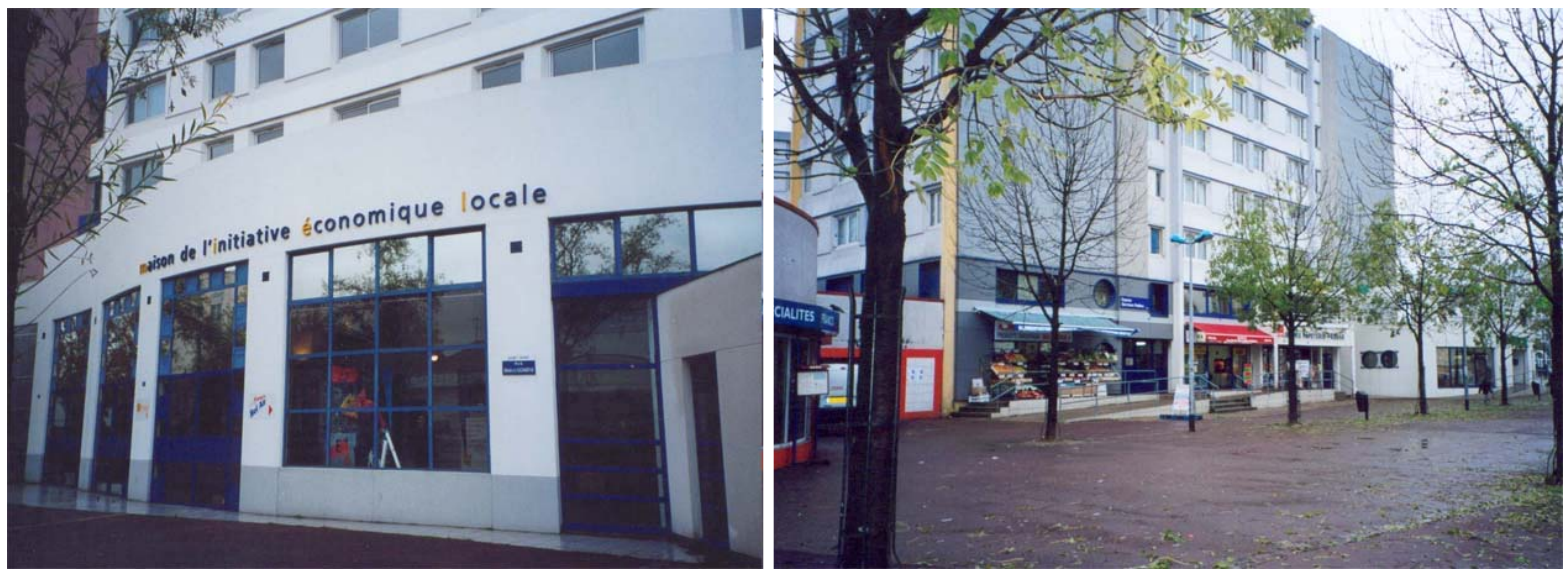

Vista das intervenções de reabilitação no conjunto Franc-Moisin, onde se observa a utilização dos térreos para a implantação de comércios e serviços (à direita), além de um equipamento voltado à geração local de empregos (à esquerda). As fotos foram tiradas pela comitiva da COHAB-SP em visita para conhecer o programa francês de reabilitação de conjuntos. Foto: Suely Muniz, 2001.

Em 1999, os programas GPU foram substituídos por um novo modelo de contrato entre o Estado nacional e as regiões com vistas à reabilitação das periferias em crise, com a instituição de dois novos instrumentos operacionais: os programas GPV - Grande Projeto de Cidade (Grand Projet de Ville) e os ORU - Operações de Renovação Urbana (Opérations de Renouvellement Urbain). De certa forma, estes programas englobam e dão continuidade aos princípios formulados ao longo das experiências anteriores, desde a formatação dos primeiros contratos de cidade (DSU) do X Plan.

Os ORU constituem-se em programas voltados à melhoria da qualidade de vida nas periferias, com vistas à qualificação física e integração econômica e social desses locais à dinâmica urbana. Apresentam menor porte e alcance - físico, social e financeiro que os GPV, representando um aporte financeiro complementar para a renovação urbana que, de outro modo, estaria fora das possibilidades orçamentárias dos municípios que participam do programa ${ }^{131}$.

Já os contratos firmados sob a forma dos Grandes Projetos de Cidade apresentam maior porte e ambição, tendo sido implementados ao longo do período 20012006, configurando-se num

${ }^{130}$ Cf. BLOS, Dorotea. Op. Cit., 1999, p. 448-9.

${ }^{131}$ Cf. Ministère du Logement et de la Ville. Politique de la Ville: Le renouvellement urbain. Acessado do site do Ministério Francês da Habitação e da Cidade: http://www.ville.gouv.fr/infos/ville/index.html em 5 de novembro de 2008. 
projeto global de desenvolvimento social e urbano, que tem por objetivo integrar a um ou vários bairros de sua aglomeração. Permite a execução de operações pesadas de requalificação urbana. Seu objetivo é o de melhorar as condições de vida dos habitantes e fazer, de modo profundo e duradouro, a transformação da imagem e da percepção do bairro.

Da mesma forma, atua por meio de ações de revitalização e de revalorização social, a fim de devolver um valor econômico a estes territórios.

A concepção do Grande Projeto de Cidade, conduzido desde o começo em conjunto com os moradores, deve conciliar a implementação das intervenções de modo a conseguir um impacto rápido na vida cotidiana dessa população com as ações que precisam, necessariamente, ser implementadas a longo prazo.

Nos Grandes Projetos de Cidade serão incluídos programas de:

- reestruturação do parque edificado (renovação e diversificação da oferta de moradias, melhorias da rede de equipamentos públicos locais, tratamento dos centros comunitários),

- implantação de serviços públicos e coletivos,

- rompimento com o isolamento dos bairros e sua integração à aglomeração urbana (melhorias no transporte público, melhor distribuição das diferentes categorias de habitação) ${ }^{132}$.

$\mathrm{Na}$ imagem à página seguinte é possível verificar a extensão do programa segundo os contratos firmados até junho de 2000, tanto os contratos GPV quanto ORU. Orly-Choisy-le-Roi e Grigny, objeto de intervenções desde as primeiras operações HVS são novamente contemplados com ações de renovação urbana: esta com um contrato GPV e, aquela, com um contrato ORU. A aglomeração de Clichy-sous-Bois/Montfermeil também foi contemplada com um contrato GPV para o período 2001-2006.

O GPV Clichy-sous-Bois/Montetfermeil foi firmado entre o Estado nacional e o Conselho Regional de Île-de-France, o Conselho Geral de Seine-Saint-Denis, os municípios de Clichy-sous-Bois e Montfermeil, a Comunidade da aglomeração ${ }^{133}$ de Clichysous-Bois e de Montfermeil, a Caisse de Dépôts et Consignations e os promotores imobiliários sociais do território. Este objetivava a requalificação urbana das áreas em maiores dificuldades desses municípios por meio da concentração de recursos financeiros nas intervenções, quer seja diretamente nesses locais, quer seja em outros pontos da aglomeração que resultem em melhorias diretas nesses locais. O perímetro de intervenção prioritária GPV representa um conjunto de 23.500 habitantes, sendo 16.500 em Clichy e 7.000 em Montfermeil, em 6.020 unidades habitacionais (4.790 e 1.230, respectivamente). Estes valores representavam quase metade dos moradores dessa aglomeração e cerca de

${ }^{132}$ Ministère du Logement et de la Ville. Politique de la Ville: Le renouvellement urbain: Les Grands projets de ville (GPV). Acessado do site do Ministério Francês da Habitação e da Cidade: http://www.ville.gouv.fr/infos/ville/index.html em 5 de novembro de 2008.

133 A comunidade da aglomeração (communauté d'agglomération) consiste num ente jurídico que congrega os dois municípios em questão, em função de seus interesses em comum. 
um terço do parque residencial. Proporcionalmente, atingia 58\% dos moradores e $52 \%$ das residências de Clichy-sous-Bois, e 29\% e 14\% em Montfermeil, respectivamente ${ }^{134}$.

\section{A Renovação Urbana \\ Grandes Projetos de Cidade (GPV) e Operações de Renovação Urbana (ORU) ${ }^{135}$}
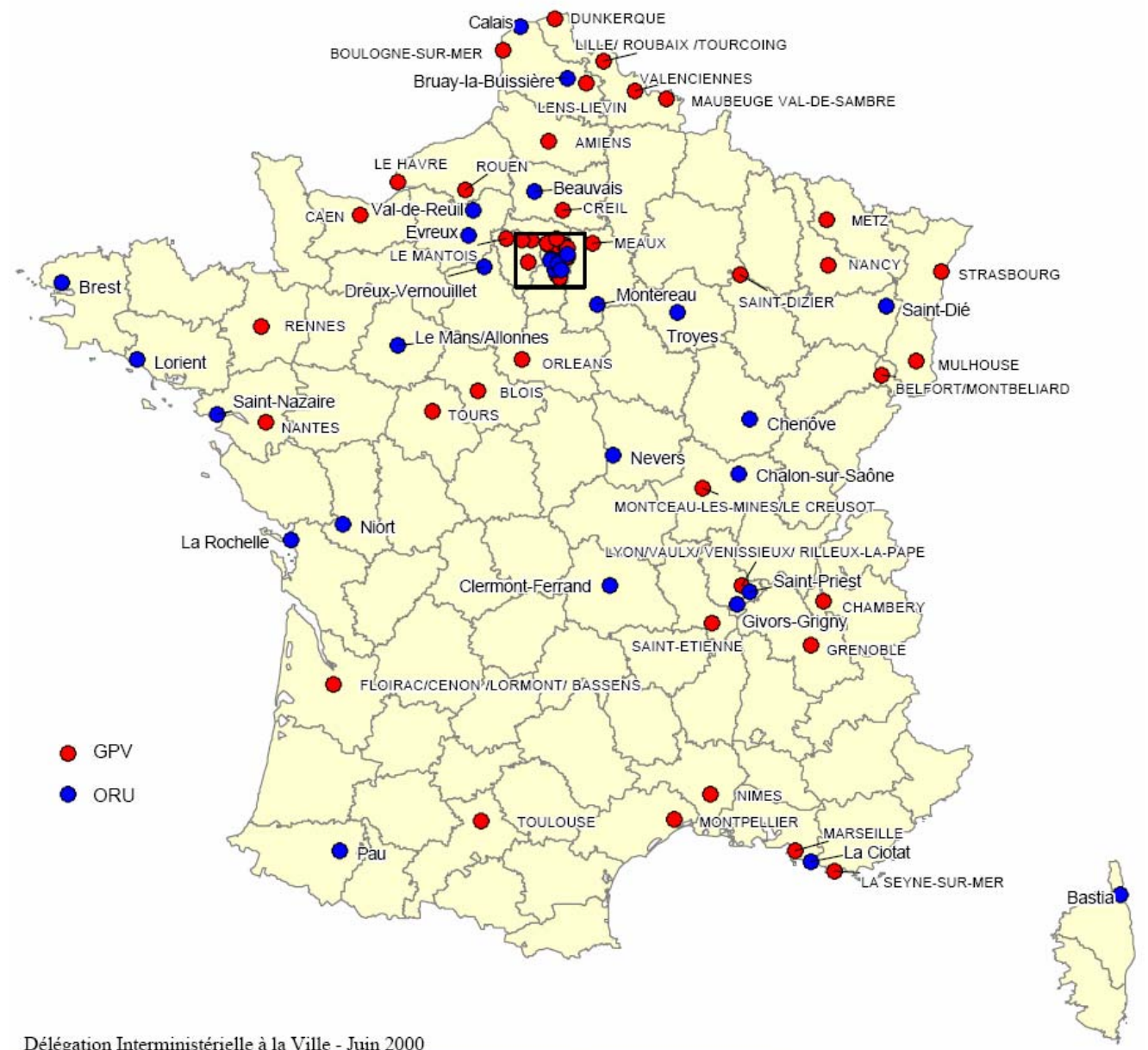

Délégation Interministérielle à la Ville - Juin 2000

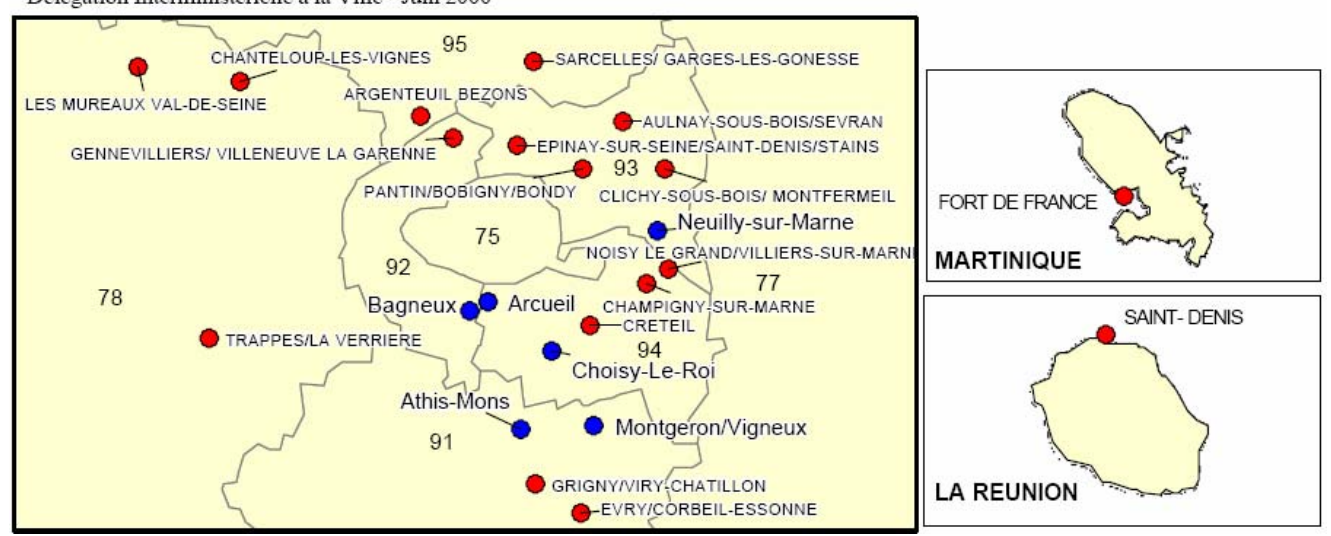

134 Convention Territoriale. Grand Projet de Ville: Clichy-sous-Bois/Montfermeil 2001-2006. Bobigny, 2000, p. 6-7. Acessado e baixado do site da Municipalidade de Clichy-sous-Bois em 4 de novembro de 2008: http://www.clichy-sous-bois.fr/jsp/site/Portal.jsp?page_id=20.

${ }^{135}$ Ministère du Logement et de la Ville. Politique de la Ville: Le renouvellement urbain: La Carte des Grands projets de ville et Óperations de renouvellement urbain. Acessado do site do Ministério Francês da Habitação e da Cidade: http://www.ville.gouv.fr/infos/ville/index.html em 5 de novembro de 2008. 


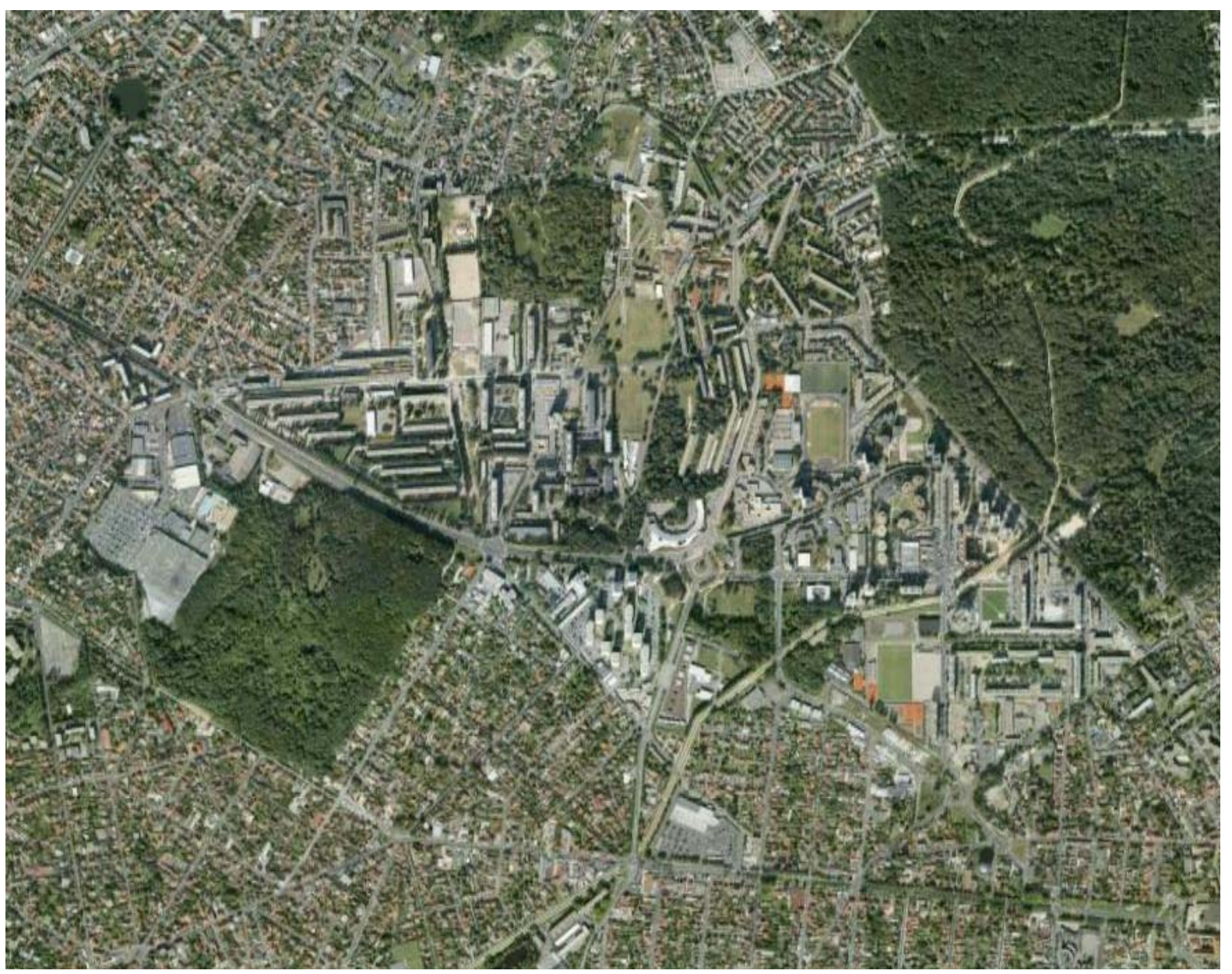

Vista das cidades de Clichy-sous-Bois (à esquerda) e Montfermeil. É visível o impacto do grand ensemble na estrutura urbana dos dois municípios. Imagem de 21 de outubro de 2007 extraída do Google Earth em 6 de novembro de 2008.

Entre os problemas verificados nessa aglomeração - mesmo depois de quase duas décadas de intervenções públicas com enfoque direto na reabilitação urbana constatavam-se, quando da assinatura da convenção territorial: alto índice de desemprego, ultrapassando a $25 \%$ no bairro de Bosquets (Montfermeil), entre 20 e 25\% em Haut-Clichy e entre 15 e 20\% em Bas Clichy; alta concentração de população estrangeira, com frequência recém-chegada, passando de $50 \%$ do total de moradores de Bosquets, entre 40 e 50\% em Haut-Clichy e entre 30 e $40 \%$ em Bas-Clichy; a grande quantidade de moradias sobre-ocupadas e congestionadas; mobilidade reduzida; e grande concentração de população jovem, com menos de 20 anos, representando mais de $50 \%$ da população de Bosquets e entre 40 e $50 \%$ em Haut e Bas-Clichy ${ }^{136}$. Além desses problemas sociais vividos pelas populações residentes nos grandes conjuntos dessa aglomeração, outros problemas e condicionantes afetavam o restante da região:

- um déficit geral de equipamentos esportivos, culturais, sociais e de lazer;

${ }^{136}$ Convention Territoriale. Op. Cit., 2000, p. 7. 
- uma precária distinção entre os espaços públicos e os privados;

- uma insuficiente valorização dos pontos relevantes do local, como os espaços verdes e os elementos patrimoniais notáveis;

- o insulamento do território com relação à rede de transportes públicos da metrópole de Paris;

- o insulamento de Montfermeil por um sistema viário que funciona como uma barreira urbana;

- a ausência de estruturação do espaço urbano em Clichy-sous-Bois;

- um déficit de segurança que se reflete num profundo sentimento de insegurança nessa área ${ }^{137}$.

O GPV Clichy-Montfermeil define como objetivo final para a área o aumento da diversidade, não apenas social mas também física e funcional. Para atingi-lo o GPV estruturou-se em quatro eixos prioritários, cada qual estabelecendo objetivos específicos para o enfrentamento dos problemas diagnosticados na aglomeração. O primeiro eixo era a "coerência urbana", sob a qual se organizavam os seguintes objetivos: conectar a área à aglomeração parisiense e melhorar a mobilidade interna; ordenar os espaços abandonados; valorizar o patrimônio ambiental; e reconquistar os espaços comunitários. O segundo eixo prioritário, a "qualidade da moradia", tinha por objetivos específicos: a reestruturação profunda dos condomínios degradados; ações de requalificação e de prevenção sobre os demais condomínios; e a qualificação do parque habitacional social. O terceiro eixo consistia na "modernização dos equipamentos públicos", baseado: na renovação e animação dos equipamentos existentes; e no desenvolvimento da oferta de novos equipamentos. O quarto eixo consistia na "gestão local, vida cotidiana e luta contra a exclusão", que se buscava por meio de: uma gestão urbana local; uma qualificação da vida social; e pela luta contra a exclusão econômica e social ${ }^{138}$.

Em dezembro de 2004 a comunidade da aglomeração de Clichy-sousBois/Montfermeil assinou um convênio com a ANRU - Agência Nacional para a Renovação Urbana (Agence Nationale pour la Rénovation Urbaine), redimensionando os objetivos a serem perseguidos e a escala da intervenção, instituindo, desse modo, o PRU - Projeto Intermunicipal de Renovação Urbana (Projet de Rénovation Urbaine), com o intuito de reintroduzir a diversidade social na área e reduzir a rejeição ao bairro. Isso deveria ser conseguido com a demolição das moradias localizadas nos condomínios mais degradados (cerca de 1.400) e a construção de aproximadamente 2.000 novas unidades num prazo de dez anos, das quais 1.548 logo nos cinco primeiros anos da aplicação do Projeto, assim como a reabilitação de 921 habitações sociais.

${ }^{137}$ Convention Territoriale. Op. Cit., 2000, p. 7.

${ }^{138}$ Convention Territoriale. Op. Cit., 2000, p. 12-9. 


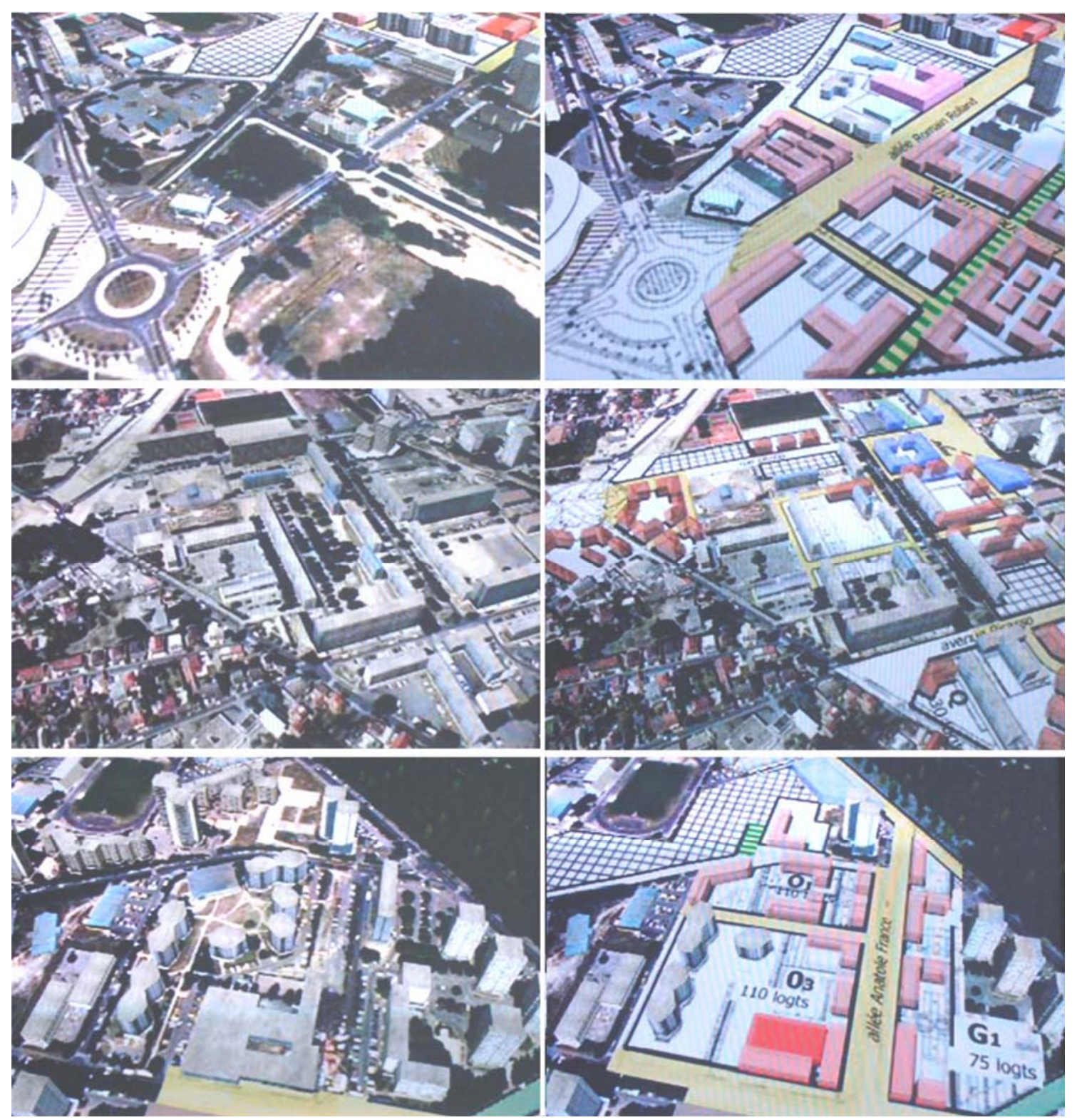

Imagens extraídas do vídeo institucional Projet de Renovation Urbaine com as propostas constantes do Projeto de Renovação Urbana da aglomeração de Clichy-sous-Bois/Montfermeil, com a situação atual (à esquerda) e a proposta de intervenção (à direita). Acessado e baixado do site da Municipalidade de Clichy-sous-Bois em 6 de novembro de 2008 de http://www.clichy-sous-bois.fr/jsp/site/Portal.jsp?page_id=152.

Além do enfoque habitacional, previa-se a demolição dos centros comerciais degradados (Bargue, Anatole France e da Tour Utrillo) e a recomposição de dois pólos de comércios e serviços. Estavam previstos, também, a requalificação do sistema viário (incluída a principal via coletora do conjunto, a fim de estabelecer o transporte público em local apropriado), bem como a criação de novas ruas e a reconstrução dos espaços públicos, além do ordenamento paisagístico de forma a garantir a continuidade dos espaços verdes no território. A primeira fase do projeto, prevista para o período 2004-2010, contava com orçamento estimado de 480 milhões de euros, dos quais 324,5 milhões 
repassados pela ANRU. Desse valor, $80 \%$ destinavam-se a intervenções no parque habitacional $^{139}$.

Enquanto se desenrolavam as discussões para a aprovação da ZAC de Dhuys ${ }^{140}$, destinada a estabelecer o limite operacional para a implementação do PRU, o grand ensemble de Clichy-sous-Bois explodiu em convulsão social em outubro de 2005, como visto anteriormente. O quadro contemporâneo de rejeição e crise revela claramente os limites da política de reabilitação dos grandes conjuntos franceses, uma vez que nem mesmo a seqüência contínua de pesado investimento público - de um país altamente desenvolvido econômica e socialmente - foi capaz de reverter o quadro de exclusão instalado nessa área.

Ainda que, no caso francês, essa política de reabilitação tenha sido muito mais ampla e complexa, a ponto de atuar em frentes diversas e conexas, enfrentando as distintas dimensões do problema - física, funcional e socialmente -, esta política não foi capaz (e jamais o seria) de desmontar os mecanismos de reprodução das condições que geravam essa exclusão, produzindo esses territórios em crise. Partindo da análise de BOURDIEU, podemos considerar a própria retórica da politique de la ville contraditória e ingênua, em um contexto de desregulamentação e encolhimento do papel estatal, de "demissão do Estado", em que se apostou em soluções pontuais para resolver problemas sociais e econômicos estruturais.

Esse obscurecimento das reais causas do problema, procurando em circunscrições territoriais a solução de questões que se originam nas relações de produção, é respondida pelo próprio MARX, em sua crítica aos socialistas utópicos e suas ilusões sociais, que relevavam a luta de classes:

Procuram (...) atenuar a luta de classes e conciliar os antagonismos. Continuam a sonhar com a realização experimental de suas utopias sociais: instituição de falanstérios isolados, criação de colônias no interior, fundação de uma pequena Icària - edição em formato reduzido da nova Jerusalém -, e para dar realidade a todos esses castelos no ar vêem-se obrigados a apelar para os bons sentimentos e cofres dos filantropos burgueses. Pouco a pouco caem na categoria dos socialistas reacionários ou conservadores (...), e só se distinguem deles por um pedantismo mais sistemático, uma fé supersticiosa e fanática nos efeitos miraculosos de sua ciência social. ${ }^{141}$

\footnotetext{
${ }^{139}$ Mairie de Clichy-sous-Bois. Le Projet de Rénovation Urbaine. Acessado no site da Municipalidade de Clichy-sous-Bois em 4 de novembro de 2008: http://www.clichy-sousbois.fr/jsp/site/Portal.jsp?page_id=21.

${ }^{140}$ Aprovada, por unanimidade, pelo Conselho Municipal, em 31 de janeiro de 2006.

${ }^{141}$ MARX, Karl e ENGELS, Friederich. Manifesto Comunista. São Paulo: Boitempo, 2007, p. 67-8.
} 
CAPÍTULO 2

\section{A ATUAÇÃO DO ESTADO \\ BRASILEIRO NO CAMPO \\ DA HABITAÇÃO POPULAR:}

DO SANITARISMO AOS GRANDES CONJUNTOS HABITACIONAIS 
Ao longo de todo o século $X X$, ganhando especial velocidade a partir dos anos finais da década de 1930, o Estado brasileiro interveio na regulação e produção habitacional, com ênfase na questão da moradia destinada às camadas de mais baixa renda da população a qual, veremos, foi muito mais retórica que disposição para a busca de soluções reais e efetivas.

Ao longo do período analisado, a abordagem estatal à questão variou em intensidade, foco e matiz. Ora mais presente na regulação, ora atuando como agente de fomento, ou ainda sob a forma de produtor direto de unidades habitacionais, o Estado atuou de forma decisiva, justamente no período de mais intensa urbanização da história do Brasil. É impossível estudar as cidades e o desenvolvimento urbano nesse momento sem levar em conta o papel determinante desempenhado pelo Estado na configuração do território, na qualidade de promotor, ordenador e financiador desse desenvolvimento.

Nesta primeira década do século XXI a coexistência de bairros de altíssima qualidade ambiental, dotados de completa infra-estrutura urbana e habitados por segmentos de alta renda, com favelas e loteamentos clandestinos de grande precariedade e insalubridade, passando pelos extensos conjuntos habitacionais de promoção pública, habitados pelas camadas de mais baixa renda da população, vítimas diretas da violência urbana que acometeu as cidades brasileiras a partir do final do século $X X$, são produto e reflexo direto da dialética da atuação estatal no processo de urbanização brasileiro. Quer seja pela ação direta, pela ausência ou pela coação.

Evidente nas nossas cidades, sobretudo nas metrópoles, a atuação do Estado, sob diversas formas, jamais chegou perto de alterar o padrão urbano e habitacional dos segmentos populares, baseado na autoconstrução em loteamentos periféricos precários, distantes e sem infra-estrutura básica, bem como a favelização. Ainda assim, a habitação social e a regulação urbana mantiveram-se presentes nos discursos e nas políticas oficiais de todos os governos a partir da Revolução de 1930, dos mais diversos posicionamentos ideológicos, com maior ou menor ênfase, é verdade, mas sem jamais arranhar, contudo, o processo principal por que nossas cidades se expandiam: a autoconstrução em loteamentos distantes e precários.

OLIVEIRA vê uma funcionalidade nesse padrão de ocupação e urbanização do território, necessário ao desenvolvimento e expansão de nosso capitalismo periférico com baixa acumulação, por meio da super-exploração da força de trabalho, que ao construir sua própria casa retira a moradia do custo de sua reprodução, permitindo um rebaixamento 
ainda maior dos valores dos salários ${ }^{1}$. MARICATO também analisa essa característica da urbanização brasileira, na qual os trabalhadores necessitam apelar à autoconstrução da moradia a fim de suprir suas necessidades por habitação, uma vez que não encontram nem políticas públicas nem um mercado imobiliário privado ao alcance dos ganhos representados por seu salário ${ }^{2}$.

Tendemos a concordar com os autores; porém, ainda que o processo principal de urbanização e provisão habitacional para as camadas de baixa renda tenha se dado sob essa forma, por outro lado, a atuação do Estado foi marcante e decisiva em diversos momentos. É verdade que durante o período da mais relevante presença estatal nesse campo, com a atuação do BNH no financiamento habitacional e urbano, apenas um quarto de seus recursos se destinou aos segmentos populares, configurando-se este, paradoxalmente, num momento de vertiginoso crescimento dos núcleos de favelas. É preciso considerar, porém, que mesmo representando uma porcentagem pouco significativa do incremento habitacional popular no período, o Estado jamais abdicou de sua prerrogativa de atuar, regular, financiar e produzir habitação social.

Assim, precisamos a cada momento identificar as características da intervenção estatal no campo da habitação popular, distinguindo quais as motivações que a originaram, as premissas que a orientaram, bem como os resultados das mais relevantes políticas e programas públicos ao longo do século $\mathrm{XX}$, os quais foram decisivos ao conferir às cidades brasileiras seus traços mais patentes, e que acabamos por tomar como inerentes às mesmas, muitas vezes sem ter claro o processo que nos legou essas características particulares.

Desse modo, procuramos desenvolver este estudo distinguindo entre as grandes linhas estabelecidas pelos programas e políticas públicas incidentes sobre o desenvolvimento urbano, suas motivações, seus objetivos e os resultados obtidos, e a atuação direta do Estado como produtor de moradia sob a forma de conjuntos habitacionais, procurando identificar uma linha evolutiva nesse processo, desde as incipientes iniciativas do final do anos 1930 até os grandes conjuntos populares produzidos pelas COHABs durante o período de existência e operação do BNH.

\footnotetext{
${ }^{1}$ Cf. OLIVEIRA, Francisco. Crítica à Razão Dualista: o Ornitorrinco. São Paulo: Boitempo, 2003, p. 59.

${ }^{2}$ MARICATO, Ermínia. Autoconstrução: a Arquitetura Possível in MARICATO, Ermínia (Org.). A produção capitalista da casa (e da cidade) no Brasil Industrial. São Paulo: Alfa-Ômega, 1982.
} 


\subsection{Industrialização, Urbanização e a Atuação do Estado Brasileiro no Campo da Habitação Popular no Início do Século XX}

Ao longo do século $X X$ ocorreu no Brasil um intenso processo de urbanização, caracterizado por um afluxo populacional advindo da migração rural-urbana que atravessou o século, alterando a configuração do padrão de ocupação do país. Se em 1940 a população rural representava $68,76 \%$ do contingente populacional total, esse quadro se altera radicalmente ao longo dos sessenta anos seguintes, quando as populações urbana e rural passam a representar, respectivamente, $81,25 \%$ e $18,75 \%$ do total da população brasileira segundo dados do Censo IBGE/2000.

Este processo de intensa e rápida ocupação do território para fins urbanos está diretamente associado à combinação de "crescimento urbano industrial com regimes arcaicos de produção agrícola"3. Essa "industrialização com baixos salários" incentivada pelo Estado, revelou-se "predatória com a força de trabalho" ${ }^{4}$, uma vez que não gerava remuneração suficiente para garantir acesso digno aos serviços e equipamentos urbanos, como moradia, transporte, saneamento, entre outros. A integração dessas levas de migrantes rurais para o meio urbano como mão-de-obra mal remunerada para a indústria nascente acabou por gerar uma conjuntura de elevados contingentes populacionais sem acesso às condições mínimas de urbanidade, representada por uma moradia digna.

$\mathrm{Na}$ verdade, essa compressão dos salários dos trabalhadores - e que terá reflexos imediatos no padrão de urbanização que se instalou em nossas cidades - constituise na própria causa da industrialização brasileira:

com a vinda das indústrias multinacionais para o país, estabeleceu-se um padrão de crescimento em que os baixos salários não eram apenas uma conseqüência da injustiça inerente ao sistema capitalista, mas a própria condição para nossa industrialização, o que Roberto Schwarz chamou de 'industrialização com baixos salários'. O mercado interno que se formava era apenas residual, o foco da atuação das multinacionais aqui instaladas sendo, antes de tudo, a exportação. ${ }^{5}$

Salvo ações pontuais por parte do poder público, em suas diversas escalas, até o período da República Velha a questão da habitação era encarada como uma relação entre particulares, mesmo quanto à regulação dessa relação. Não se verificavam ações das administrações públicas com o intuito de enfrentar o problema habitacional como uma questão a ser resolvida pelo Estado.

\footnotetext{
${ }^{3}$ MARICATO, Ermínia. Op. Cit., 1996, p. 39.

${ }^{4}$ MARICATO, Ermínia. Op. Cit., 1996, p. 40.

${ }^{5}$ FERREIRA, João Sette Whitaker. O Mito da Cidade-Global: o papel da ideologia na produção do espaço urbano. Petrópolis: Vozes: Unesp: Anpur, 2007, p. 44. Grifo no original.
} 
As primeiras iniciativas públicas para o enfrentamento da questão habitacional podem ser encontradas ainda nos primeiros anos do século XX. Nesse período, porém, a questão aparece travestida de preocupação sanitária, vinculada à eliminação das favelas e mocambos, focos de insalubridade e doenças no coração das cidades brasileiras, sobretudo no Rio de Janeiro e Recife. Essas ações de desfavelamento ou descortiçamento muitas vezes vinham acompanhadas de projetos de embelezamento urbano.

Durante a década de 1930, a habitação não figurava entre as reivindicações dos trabalhadores. Quando surgiam, tendiam a se desenvolver na forma de pressão pelo aumento dos salários, uma vez que parte considerável dos salários destinava-se ao pagamento dos aluguéis das moradias, forma predominante da habitação proletária do período. Quando surgiam pressões contra o aumento dos valores dos aluguéis elas tendiam a se dirigir ao proprietário da moradia, e não ao Estado ${ }^{6}$.

As primeiras iniciativas de envergadura para alterar o quadro de crescente carência habitacional surgiram vinculadas à constituição dos Institutos de Aposentadoria e Pensões - IAPs, durante o primeiro governo de Getúlio Vargas, sendo criados seis entre 1933 e 1938, destinados a categorias profissionais específicas ${ }^{7}$. Os IAPs tinham seus fundos constituídos por contribuições tripartites Estado/empregador/empregado; a administração dos Institutos também obedecia a essa proporcionalidade.

Aos institutos de previdência coube

papel fundamental na expansão do capitalismo e da industrialização no Brasil em três frentes: manutenção do consumo mínimo das classes de menor renda incapacitadas para o trabalho por velhice, doença ou morte do chefe de família; elevação da capacidade de trabalho dos assalariados através da assistência médica; e fonte de recursos para investimentos em diversos setores da economia ${ }^{8}$.

Apesar de não ser esta sua função precípua, os IAPs foram os principais promotores de habitação do período. Essa atribuição conferida aos IAPs de promotores habitacionais foi inserida pelo Estado varguista na constituição de sua legislação específica. Nos debates acerca da constituição da Previdência Social no Brasil, a habitação não representava uma demanda dos trabalhadores ${ }^{9}$.

\footnotetext{
${ }^{6}$ Cf. FARAH, Marta. Estado, previdência social e habitação. Dissertação de Mestrado apresentada à FFLCH/USP - Departamento de Ciências Sociais. São Paulo: FFLCH/USP, 1983, p. 35.

${ }^{7}$ IAPM (marítimos), IAPB (bancários), IAPC (comerciários), IAPI (industriários), IAPETEC (condutores de veículos e empregados de empresas de petróleo) e IAPE (estivadores). Cf. BONDUKI, Nabil. Origens da Habitação Social no Brasil: Arquitetura Moderna, Lei do Inquilinato e Difusão da Casa Própria. São Paulo: Estação Liberdade: FAPESP, 1998, p. 102.

${ }^{8}$ COHN, 1981, p. 15 apud BONDUKI, Nabil. Op. Cit., 1998, p. 103.

${ }^{9}$ Cf. FARAH, Marta. Op. Cit., 1983, p. 27.
} 
É preciso, aqui, compreender os determinantes históricos que impuseram ao Estado a questão habitacional como um problema seu, demandando ações políticas para seu atendimento, deslocando-a do campo das negociações entre particulares para o da formulação de uma política pública nacional. Para tanto, faz-se necessário identificar o contexto em que a ação estatal no setor da habitação toma impulso, identificando os determinantes dessa ação no quadro de nosso capitalismo periférico, vinculando as políticas governamentais ao processo de expansão do capitalismo brasileiro no início do século $X X$.

FARAH estuda a intervenção do Estado na questão habitacional, a partir da reconstrução da atuação dos Institutos de Aposentadorias e Pensões - IAPs. Em seu estudo, ela procura identificar as determinantes que levam o Estado, no contexto da formação social capitalista brasileira, a intervir na questão habitacional por meio de uma política governamental.

Para isso, parte dos conceitos desenvolvidos pela corrente francesa ligada à "'nova' sociologia urbana européia"10. Segundo essa formulação teórica, a ação governamental na questão habitacional dar-se-ia condicionada a duas formas determinantes gerais: a primeira relacionada à "questão da reprodução da força de trabalho e a segunda, à acumulação de capital no setor imobiliário"11.

A primeira ordem de determinações estaria relacionada à contradição interna ao processo de desenvolvimento do processo de acumulação capitalista. Essa contradição dar-se-ia pelo fato de que não são criadas condições de reprodução da força de trabalho necessárias a acompanhar a expansão do processo de acumulação capitalista. Por um lado, a necessidade de acumulação pressionaria pela ampliação da extração da mais-valia do trabalhador e, de outro, a produção capitalista da mercadoria habitação buscaria a elevação do "preço" dessa mercadoria, pressionando pela elevação do custo de reprodução da força de trabalho. Essa contradição seria a principal determinante a originar a intervenção do Estado na questão habitacional "e atenuá-la seria sua principal 'função"'12.

Essa ordem de determinação seria desdobrada em duas linhas principais: de um lado, garantir a reprodução da força de trabalho ante a contradição da necessidade de extração e acumulação de mais-valia, uma vez que essa contradição poderia levar a um

\footnotetext{
${ }^{10}$ Essa corrente teve como representantes Manuel Castells, Jean Lojkine e Christian Topalov, e tinha como preocupação o estudo da intervenção do Estado na problemática urbana vinculada ao processo de acumulação capitalista. FARAH, Marta. Op. Cit., 1983, p. 9.

${ }^{11}$ FARAH, Marta. Op. Cit., 1983, p. 10.

12 FARAH, Marta. Op. Cit., 1983, p. 10.
} 
"estrangulamento no processo de produção"13; de outro, garantindo a reprodução das condições de dominação, pois o não-atendimento às demandas por habitação poderiam degenerar num aprofundamento do antagonismo entre as classes dominantes e as classes dominadas, podendo levar, no limite, a "questionamentos dos fundamentos do modo de produção capitalista"14. Nesse caso, o papel do Estado estaria vinculado a uma determinação de caráter político-ideológica, visando à manutenção e reprodução das condições de dominação.

Essa determinação da atuação governamental como forma de garantir a reprodução ampliada da força de trabalho parece pouco plausível no caso brasileiro, especificamente, e no caso latino-americano de forma mais geral.

Segundo FARAH, a existência de mão de obra em grande quantidade tornaria desnecessário o investimento na reprodução da força de trabalho. Essa abundância de mão de obra tem como origem, segundo análise de OLIVEIRA ${ }^{15}$, o padrão econômicoprodutivo preexistente no Brasil, a saber, a monocultura agro-exportadora, fundada no trabalho compulsório. Esse padrão conferiu um caráter autárquico à economia monocultora, sem constituir efetivamente um campesinato nacional, como na Europa, em que serviu de base à expansão industrial.

\section{Segundo OLIVEIRA}

quando a industrialização começa a ser o motor da expansão capitalista no Brasil, ela tem que ser simultaneamente urbana, e tem que ser fundamentalmente urbana porque não pode apoiar-se em nenhuma pretérita divisão social do trabalho no interior das unidades agrícolas ${ }^{16}$.

Para esse autor, a indústria, no Brasil, teria que ser urbana ou não teria condições de nascer e firmar-se. Dessa forma, isso se apresenta como a causa determinante "do fato de que a nossa industrialização vai gerar taxas de urbanização muito acima do próprio crescimento da força de trabalho empregada nas atividades industriais"17.

A argumentação de OLIVEIRA visa contrapor a teorização sobre o "inchaço" e a marginalidade social nas cidades brasileiras. Ele não nega a existência dessa

\footnotetext{
${ }^{13}$ CASTELLS, Manuel. La Cuestión Urbana. Madrid, Siglo XXI, 1974, p. 180 apud FARAH, Marta. Op. Cit., 1983, p. 11.

${ }^{14}$ FARAH, Marta. Op. Cit. 1983, p. 11.

15 Cf. OLIVEIRA, Francisco. O Estado e o Urbano no Brasil in Revista Espaço e Debates $\mathrm{n}^{\circ} 6$, junho/setembro de 1982, p. 42.

${ }^{16}$ OLIVEIRA, Francisco. Op. Cit., 1982, p. 42.

${ }^{17}$ OLIVEIRA, Francisco. Op. Cit., 1982, p. 42.
} 
marginalidade social, mas a identifica na própria composição dos exércitos industriais de reserva, não representando, assim, nem exclusão do mercado de trabalho nem exclusão da economia urbana. A significância dessa característica tem importância pela "forma peculiar pela qual a industrialização brasileira trouxe, para dentro de si, de uma só vez, de uma pancada, todo esse exército industrial de reserva, vindo dos campos para dentro das cidades"18.

Para nós, essa argumentação tem relevância para embasar a análise anterior a respeito da intervenção estatal na produção habitacional para garantir a reprodução da força de trabalho ou, melhor dizendo, da pouca significância que esse aspecto teve na ação governamental no Brasil. A afirmação de AZEVEDO corrobora essa análise, a partir de um contexto latino-americano:

Assim, por exemplo, dizer que os programas de habitação popular foram implantados nos países latino-americanos com o objetivo de garantir a 'reprodução da força de trabalho' parece ser um equívoco, em virtude do excesso de mão de obra disponível. ${ }^{19}$

Esse "excesso" de mão de obra disponível seria uma das principais razões dessa relativa omissão do Estado na formulação de políticas públicas habitacionais, já que não existiria uma pressão que pusesse em risco o equilíbrio entre a reprodução da força de trabalho e o processo de acumulação capitalista. Por outro lado, essa massa que compunha o exército industrial de reserva instalado nas cidades encontrou saídas às suas necessidades na área habitacional por meio do desenvolvimento de alternativas "precárias" de habitação.

A ausência de uma política governamental coerente com a dimensão do problema habitacional brasileiro levou à manutenção e, por vezes, ao desenvolvimento de formas não-capitalistas de produção da habitação. OLIVEIRA identifica o desenvolvimento dessas alternativas "precárias" de produção da habitação como uma das chaves do processo de expansão capitalista, que vai se intensificar a partir dos anos 1930 e 40 do século XX, uma vez que contribui para intensificar a taxa de exploração da força de trabalho:

Uma não-insignificante porcentagem das residências das classes trabalhadoras foi construída pelos próprios proprietários, utilizando dias de folga, fins de semana e formas de cooperação como o 'mutirão'. Ora, a habitação, bem resultante dessa operação, se produz por trabalho não pago, isto é, super-trabalho. Embora aparentemente esse bem não seja desapropriado pelo setor privado da produção, ele contribui para aumentar a taxa de exploração da força de trabalho, pois o seu

${ }^{18}$ OLIVEIRA, Francisco. Op. Cit., 1982, p. 43.

19 AZEVEDO, Sérgio de. Política de Habitação popular e desenvolvimento: dilemas, desafios e perspectivas. In DINIZ, Eli (Org.). Políticas públicas para áreas urbanas: dilemas e alternativas. Rio de Janeiro: Zahar, 1982, p. 101 apud FARAH, Marta. Op. cit. 1983, p. 12. 
resultado - a casa - reflete-se numa baixa aparente do custo de reprodução da força de trabalho - de que os gastos com habitação são um componente importante - e para deprimir os salários reais pagos pelas empresas. Assim, uma operação que é, na aparência, uma sobrevivência de práticas de 'economia natural' dentro das cidades, casa-se admiravelmente bem com um processo de expansão capitalista, que tem uma de suas bases e seu dinamismo na intensa exploração da força de trabalho ${ }^{20}$.

Essa passagem demonstra de que maneira os custos de reprodução da força de trabalho referentes à moradia foram apropriados pelos trabalhadores, sendo parte fundamental do processo de expansão capitalista. Paralelamente, a atuação do Estado no sentido de se tornar um agente importante no suprimento à demanda habitacional foi pouco significativa. O Estado nacional privilegiou, na divisão dos recursos públicos, os setores estratégicos à acumulação capitalista, em detrimento da reprodução da força de trabalho ${ }^{21}$.

\section{Segundo FERREIRA,}

ao contrário do que ocorrera na economia fordista-keynesiana nos países centrais e seus estados-providência, o processo de concentração populacional nos grandes centros industriais brasileiros não foi acompanhado por uma ação do Estado que garantisse condições mínimas de infra-estrutura urbana e qualidade de vida, pois isso resultaria, em última instância, na elevação do custo de reprodução da classe trabalhadora, o que não interessava às classes dominantes industriais. Em suma, a 'melhor' política habitacional, no contexto do subdesenvolvimento brasileiro, era a da 'não-política habitacional'. Daí decorre o forte suporte à cultura da 'casa própria' nas políticas habitacionais, em especial durante o regime militar, no âmbito do Sistema Financeiro da Habitação - SFH. ${ }^{22}$

A "segunda ordem de determinações" dessa ação do Estado na área habitacional estaria vinculada à contribuição do agente estatal na acumulação de capital internamente ao setor imobiliário. Isso se daria por meio da disponibilização dos fundos públicos no financiamento às construções ou na constituição de um setor público de construção habitacional, criando as condições de produção em massa. Na outra ponta, o Estado participa no financiamento aos compradores, possibilitando a expansão do mercado consumidor da mercadoria habitação ao constituir essa expansão da demanda solvável, viabilizando o desenvolvimento capitalista desse setor. A atuação do agente estatal sob essa forma se deu, mais precisamente, quando da constituição do SFH/BNH, conforme analisado por $\mathrm{BOLAFFI}^{23}$ e discutido nesse capítulo mais à frente.

\footnotetext{
${ }^{20}$ OLIVEIRA, Francisco. Crítica à Razão Dualista: o Ornitorrinco. São Paulo: Boitempo, 2003, p. 59.

${ }^{21}$ Cf. FARAH, Marta. Op. Cit. 1983, p. 11.

${ }^{22}$ FERREIRA, João Sette Whitaker. Op. Cit., 2007, p. 45.

${ }^{23}$ BOLAFFI, Gabriel. Habitação e urbanismo: o problema e o falso problema in MARICATO, Ermínia (Org.). A produção capitalista da casa (e da cidade) no Brasil Industrial. São Paulo: Alfa-Ômega, 1982. Bolaffi analisa nesse trabalho os objetivos enunciados e a atuação efetiva do BNH enquanto órgão
} 
Para FARAH, nas origens da intervenção estatal na questão habitacional devem ser destacados dois aspectos centrais: aquilo que o Estado não fez, e a influência dessa inação no agravamento dos problemas relativos à precariedade e carência habitacionais; e as determinações de ordem político-ideológica.

O que nos interessa, nesse momento, são as motivações e objetivos que levaram o Estado a dar os primeiros passos na constituição de uma política habitacional no Brasil, e a relação dessa intervenção frente ao contexto de expansão do capitalismo nacional.

Interessam, sobremaneira, as determinações de ordem político-ideológica, que aparecem como chave para o entendimento dessa intervenção estatal que, mais do que procurar responder às demandas por habitação, parece se dar de modo a evitar a ameaça de questionamentos à estrutura capitalista. Dessa forma, FARAH vincula a ação do Estado na questão habitacional à promoção de uma pretensa "paz social"24, entendendo essa como "função" primordial da ação governamental no setor habitacional.

Ao longo de toda a primeira metade do século $X X$ a moradia de aluguel teve um papel predominante no atendimento às demandas habitacionais localizadas, ocorrendo, de modo geral, em espaços urbanizados e articulados com a malha consolidada da cidade. Isso se alterou durante o Estado Novo varguista. Com a promulgação da Lei do Inquilinato e o conseqüente congelamento do valor dos aluguéis, no ano de 1942, o Estado passou a atuar com maior presença na regulamentação da relação entre proprietários e inquilinos. Inibiram-se novos investimentos na produção rentista de moradias pela iniciativa privada, colocando o desafio da produção habitacional para o Estado e para os trabalhadores.

A década de 40 é (...) crucial no que se refere à ação do Estado no setor habitacional, quando ocorrem as principais intervenções do governo federal congelamento dos aluguéis, produção em massa de moradias por intermédio dos IAPs e criação da Fundação da Casa Popular. Além disso no mesmo período consolidou-se a aceitação, pelo Estado e pela população, de alternativas habitacionais precárias, ilegais e excluídas do âmbito capitalista, como a favela e a casa própria em loteamentos clandestinos e desprovidos de infra-estrutura. Este processo ocorreu numa conjuntura dinâmica de transformações políticas, urbanização, crescimento econômico, mobilização popular e redesenho urbano ${ }^{25}$.

Na década de 1940 as reivindicações deslocaram-se ao Estado, deixando de se referir à questão do aluguel, exclusivamente, devido a dois fatores principais: as novas funções assumidas pelo Estado com a Revolução de 30, relativamente à "extensão dos

constituído para enfrentar o problema do "déficit" habitacional do país e seu papel enquanto agente econômico.

${ }^{24}$ Cf. FARAH, Marta. Op. Cit., 1983, p. 17 e 18.

${ }^{25}$ BONDUKI, Nabil. Op. Cit., 1998, p. 209. 
direitos sociais de cidadania" e a deterioração das condições de moradia, esta última decorrente, principalmente, "da instauração (...) de um padrão de acumulação centrado no setor industrial", com um aumento expressivo da população urbana, e que posteriormente vai se acentuar ainda mais, e da ruptura do padrão de habitação até então predominante, decorrência do congelamento dos aluguéis ${ }^{26}$.

A Lei do Inquilinato foi justificada como forma de defender os locatários contra o aumento dos aluguéis num contexto de aceleração da inflação. Ainda segundo FARAH o congelamento dos aluguéis foi uma forma do Estado atuar no rebaixamento do custo de reprodução da força de trabalho. Teria sido, também, uma medida legitimadora, ampliando a base política do Estado junto aos trabalhadores, uma vez que era uma medida que parecia ir ao encontro das reivindicações dos trabalhadores por um controle do preço dos aluguéis, contendo a pressão sobre os salários ${ }^{27}$.

BONDUKI defende que se o Estado pretendeu, com essa medida, efetivamente defender o poder de compra dos salários frente à escalada dos aumentos de preços em geral, dos aluguéis em particular, essa medida objetivava também ampliar sua legitimidade frente aos assalariados urbanos. Dessa forma, representava ainda a diminuição da pressão dos trabalhadores urbanos por aumento de salários, o que angariou para a medida o apoio das entidades empresariais patronais.

Para BONDUKI, outro aspecto, talvez o mais importante, da Lei do Inquilinato é que ela foi uma medida governamental destinada a diminuir a atratividade do setor imobiliário. Segundo ele a lei

estava relacionada a uma intenção governamental de reduzir a atração que o setor imobiliário exercia sobre investidores e capitalistas em geral, com o objetivo de concentrar recursos na montagem do parque industrial brasileiro. E, ao mesmo tempo, reduzir ou eliminar um setor social não-produtivo e que vivia basicamente de rendas. ${ }^{28}$

Dessa maneira, essa medida foi importante do ponto de vista da expansão da industrialização no Brasil ao diminuir drasticamente a atratividade do setor imobiliário, altamente rentável e seguro, onde se encontravam imobilizadas grandes quantias de

\footnotetext{
${ }^{26}$ Cf. FARAH, Marta. Op. Cit., 1983, p. 35.

${ }^{27}$ Apesar de ser parte da resposta, essa justificativa parece ainda insatisfatória para se entender os reais objetivos da promulgação da Lei do Inquilinato pelo Estado Novo varguista. Se o objetivo fosse o de defender os consumidores do aumento do custo de vida teria sido mais eficaz intervir em outros setores da economia, sobretudo no controle do preço dos alimentos, uma vez que entre os itens constantes da cesta de consumo, no período anterior a 1942, o que apresentou o menor índice de aumento foi a habitação. A atuação estatal teria se dado neste caso, então, motivada por um conjunto mais complexo de fatores que aqueles presentes na retórica oficial. Cf. BONDUKI, Nabil. Op. Cit., 1998, p. 225.
}

${ }^{28}$ BONDUKI, Nabil. Op. Cit., 1998, p. 227. 
capital, reorientando os recursos ao setor produtivo. Articulada aos demais interesses em jogo - dos trabalhadores pela contenção da escalada dos preços; dos empregadores pela redução da pressão exercida pelas reivindicações salariais; do Estado pela ampliação de sua base de sustentação política - a Lei do Inquilinato teve efeitos que em muito ultrapassaram a defesa da moradia:

Nesse complexo jogo de interesses, os mais prejudicados foram os proprietários de imóveis de locação e os mais beneficiados, os empresários urbanos, sobretudo aqueles vinculados ao setor industrial baseado na 'substituição de importações'. ${ }^{29}$

A partir de então a construção da moradia passou a ser problema do trabalhador, tendo que resolvê-lo por conta própria; na década de 1940 difundiram-se, com intensidade que ainda iria crescer, duas "novas" modalidades de habitação popular: a autoconstrução em loteamentos precários de periferia e a favela.

A essa época tiveram início algumas das mais importantes experiências em habitação coletiva do país, buscando dar uma resposta ao crescente déficit habitacional por meio de um projeto modernizante tanto urbanística quanto arquitetonicamente. É a época de implantação dos conjuntos dos IAPs - Institutos de Aposentadoria e Pensões e dos projetos inspirados claramente nas influências das Siedlungen alemãs do começo do século XX e da "Unidade de Habitação" de Le Corbusier.

Com uma produção significativa do ponto de vista de seu valor arquitetônico e urbanístico, mas muito aquém das necessidades impostas pela demanda habitacional que crescia, a atuação dos IAPs no setor habitacional se deu de forma por demais fragmentária, devido, sobretudo, a sua concepção corporativa ${ }^{30}$.

Estas experiências nunca passaram da condição de "piloto" para se tornarem efetivamente modelo de produção habitacional massiva para a superação das carências crônicas de moradia qualificada no Brasil, o que se verificava no aumento crescente do número de favelas e na expansão dos loteamentos populares periféricos, muitas vezes irregulares ou clandestinos, que a essa época atinge seu ápice.

No ano de 1945 realizou-se, na cidade de São Paulo, o Congresso Brasileiro de Arquitetura que, inspirado pelas idéias da Bauhaus e dos Congressos Internacionais de Arquitetura Moderna do período entre-guerras, propõe "um programa radical de

\footnotetext{
${ }^{29}$ BONDUKI, Nabil. Op. Cit., 1998, p. 245.

${ }^{30}$ Cf. BONDUKI, Nabil. Op. Cit., 1998, p. 115.
} 
intervenção pública em matéria de habitação popular"31, coerente com os desafios impostos pela rápida urbanização do país.

A resposta para o impasse do crescente déficit habitacional advindo da "desestruturação do mercado rentista e da incapacidade do Estado em financiar ou promover a produção de moradia em larga escala" ${ }^{32}$ foi a expansão indefinida da cidade através de loteamentos irregulares, com a auto-construção das unidades.

A fim de romper com essa ação fragmentária e realizar uma política habitacional centralizada, Getúlio Vargas chegou a propor a unificação dos IAPs sob a forma de um único órgão, o ISSB - Instituto de Serviço Social do Brasil, objetivando formar um órgão específico para a elaboração e execução de uma política habitacional nacional. O ISSB chegou a ser instituído pelo decreto 7.536/45, mas sua operação não se concretizou, devido à queda do regime naquele ano e às resistências de setores dos IAPs em proceder a essa unificação das carteiras prediais dos institutos.

Durante o governo de Eurico Gaspar Dutra, apesar de seu perfil conservador, foi criada a Fundação da Casa Popular, que foi o primeiro órgão federal criado para tratar da questão habitacional, institucionalizando-a como política de Estado, já em 1946, primeiro ano de seu governo, no dia $1^{\circ}$ de maio, numa intenção clara de ganhar legitimidade junto aos trabalhadores urbanos.

A Fundação da Casa Popular tinha objetivos ambiciosos, buscando fazer frente às demandas por moradia em todo o território nacional, tanto no meio urbano quanto rural, valendo-se dos recursos provenientes de um fundo criado pela mesma lei, que instituía o controle de todas as operações imobiliárias, como construções e financiamento de conjuntos e unidades, realizadas pelos IAPs, assim como uma contribuição obrigatória sobre as transações imobiliárias incidentes sobre tipos de imóveis específicos, de mais alto padrão, de modo a constituir uma espécie de subsídio das classes mais para as menos favorecidas $^{33}$.

Essas iniciativas encontraram fortes resistências, à direita e à esquerda, por razões várias, mas em especial no tocante à unificação das carteiras prediais sob a tutela da Fundação, por setores que tinham interesse na utilização desses recursos na incorporação e construção de unidades de mais alto padrão e, portanto, mais rentáveis.

\footnotetext{
${ }^{31}$ SACHS, Céline. Op. Cit., 1999, p. 111.

${ }^{32}$ BONDUKI, Nabil. Op. Cit., 1998, p. 281.

${ }^{33}$ Cf. BONDUKI, Nabil. Op. Cit., 1998, p. 117.
} 
Uma outra alternativa em se viabilizar recursos para compor um fundo para a Fundação foi a instituição de uma contribuição obrigatória sobre a comercialização de bens imóveis referente a 1\% do valor dos imóveis com valor superior a 100 mil cruzeiros, a ser cobrada pelos estados. Contudo, esse fundo nunca se efetivou completamente pelo reduzido empenho dos governos estaduais em cobrar essa contribuição, de um lado, e ao falseamento pelos contribuintes do valor real das transações com o intuito de escapar à contribuição, de outro. O fundo foi abolido em $1951^{34}$.

Uma das causas principais da fragilidade da Fundação da Casa Popular deveu-se ao fato de não se conseguir constituir um fundo com recursos não-orçamentários que permitissem à instituição implementar uma política habitacional equacionada com as dimensões do problema a ser enfrentado. Um órgão sem poder e sem dinheiro não foi capaz de fazer frente às demandas do período.

Se durante o governo do presidente Juscelino Kubitschek (1956-1961) o tema da habitação não esteve na linha de frente dos projetos do governo federal, a questão ressurgiu com força durante o fugaz governo de Jânio Quadros, com a tentativa de criação do Instituto Brasileiro da Habitação, proposto para ser o sucessor da Fundação da Casa Popular, tendo como eixo estruturador de sua ação o acesso à casa própria, à propriedade privada, procurando incutir os valores da classe média nos beneficiados por esse tipo de política, ao constituir uma nova classe de proprietários, afastando as camadas populares da perspectiva revolucionária ${ }^{35}$.

Anos depois, essa mesma postura ideológica em relação ao papel da propriedade privada da casa foi manifestada pelo ministro Roberto Campos, um dos principais artífices do SFH:

a solução do problema pela casa própria tem esta particular atração de criar o estímulo da poupança que, de outra forma, não existiria, e contribui muito mais para a estabilidade social do que o imóvel de aluguel. O proprietário da casa própria pensa duas vezes antes de se meter em arruaças ou depredar propriedades alheias e torna-se um aliado da ordem. ${ }^{36}$

${ }^{34}$ Cf. AZEVEDO, Sério de e ANDRADE, Luis Aureliano Gama de. Habitação e Poder: da Fundação da Casa Popular ao Banco Nacional da Habitação. Rio de Janeiro: Zahar, 1982, p. 23-4.

35 Gabriel Bolaffi relata no artigo "Habitação e urbanismo: o problema e o falso problema" (BOLAFFI, 1982) pesquisa realizada em 1960, sob patrocínio do Institute for International Social Research, que a principal aspiração das populações urbanas brasileiras à época era a casa própria. Nesse mesmo estudo se estabelecia relação entre a propriedade da habitação e posturas políticas conservadoras.

${ }^{36}$ Seminário Sobre o Plano Nacional de Habitação, São Paulo, 1966. Plano Nacional de Habitação, s.l., Banco Nacional da Habitação, 1966. V. 2, p. 20-21 apud AZEVEDO, Sérgio e ANDRADE, Luís Aureliano Gama de. Op. Cit., 1982, p. 59. 
Esse instituto deveria centralizar e coordenar a constituição das políticas voltadas à habitação e ao desenvolvimento urbano, deixando espaço para as especificidades de cada região do país, já prefigurando o que viria a ser o $\mathrm{BNH}^{37}$.

João Goulart também teve em sua pauta a constituição de uma política para o enfrentamento da questão habitacional brasileira. Para tanto, preparou projeto de lei de reforma urbana, decalcado das discussões realizadas quando do Seminário sobre a Habitação e a Reforma Urbana, promovido pelo IAB em 1963, na cidade de Petrópolis. Identificou-se a necessidade de criação de um órgão federal que pudesse articular as ações de ordenação do território e de produção habitacional, dotado de autonomia financeira e que incorporasse os órgãos correlatos, centralizando as políticas e as ações.

A Fundação da Casa Popular, ao longo de sua trajetória, era correntemente acusada de práticas clientelísticas na entrega das unidades habitacionais, com a intervenção direta de políticos na "agilização" dos processos de acesso às moradias, além de constituir um verdadeiro "poço sem fundo", visto que os investimentos quase nunca se recuperavam devido à inexistência de correção monetária sobre os valores das parcelas do financiamento, o que acabava configurando um amplo subsídio sobre a moradia, comprometendo, se não inviabilizando, o atendimento à demanda pela casa própria ${ }^{38}$.

Esses fatores contribuíram decisivamente para os resultados pífios apresentados pela Fundação e, apesar de amplamente compreendidos e diagnosticados, de impossível resolução pelo Estado populista (1945-1964), uma vez que, em sua lógica, "não interessava 'resolver o problema', ou equacionar os termos da solução, mas, antes, dele derivar dividendos políticos, quer sob a forma de votos, quer de prestígio"39.

A Fundação foi extinta no ano de 1964 após ter produzido 16.964 unidades de 60 a $70 \mathrm{~m}^{2}$ em 143 conjuntos habitacionais, resultado que representa um décimo do produzido no mesmo período pelos Institutos de Aposentadoria e Previdência e outros órgãos habilitados a essa atividade no Brasil $^{40}$.

O golpe cívico-militar de 31 de março de 1964 abortou as discussões de reforma da FCP, levando à extinção do órgão, rejeitado pelo novo regime como um "antro de

\footnotetext{
${ }^{37}$ Cf. SACHS, Céline. Op. Cit., 1999, p. 114.

${ }^{38}$ Cf. AZEVEDO, Sérgio e ANDRADE, Luís Aureliano Gama de. Op. Cit., 1982, p. 38.

39 AZEVEDO, Sérgio e ANDRADE, Luís Aureliano Gama de. Op. Cit., 1982, p. 53. Grande parte dos recursos disponíveis foram mobilizados para as cidades do Rio de Janeiro, Brasília e Belo Horizonte (40\% do total de recursos), assim como pequenas cidades do interior, enquanto São Paulo, Salvador e Porto Alegre estiveram praticamente excluídos das ações da Fundação. Cf. AZEVEDO, Sério de e ANDRADE, Luis Aureliano Gama de. Op. Cit., 1982, p. 35.
}

${ }^{40}$ Cf. SACHS, Céline. Op. Cit., 1999, p. 112. 
'corruptos, incompetentes e comunistas"'41, propiciando o advento de um Estado forte o suficiente para impor a questão habitacional como prioridade na agenda nacional.

\subsection{A Política Habitacional do Regime Autoritário de 1964: o Sistema Financeiro da Habitação e o Banco Nacional da Habitação}

Com o golpe cívico-militar de 31 de março de 1964, instituiu-se um governo com força política o bastante para vencer as resistências e eliminar a oposição ao projeto de criação de um órgão responsável, expressamente, pela eliminação do déficit habitacional brasileiro, órgão este dotado de poder e de recursos capazes de realizar sua função. Entre todas as demandas e carências existentes no país nas áreas de educação, saúde, renda, a "habitação popular é eleita pelo governo federal, em 1964, como 'problema fundamental"”42 do país.

Segundo AZEVEDO e ANDRADE a colocação da questão habitacional no centro das preocupações do novo regime tinha por objetivo "esfriar as massas" populares urbanas, procurando conquistar legitimidade e, se possível, o apoio junto às mesmas ${ }^{43}$. Contudo, esta priorização das camadas populares será rapidamente abandonada em benefício do atendimento às camadas médias, em função das maiores garantias de retorno do capital investido, como veremos.

A partir de 1964 deu-se início à construção de uma efetiva política habitacional no Brasil. Por meio da Lei 4.830 de 21 de agosto de 1964 - portanto, menos de cinco meses depois do golpe - foi criado o BNH - Banco Nacional da Habitação, o SFH - Sistema Financeiro da Habitação e o SERFHAU - Serviço Federal de Habitação e Urbanismo. A mesma lei criou, também, o mecanismo da correção monetária. Tal agilidade só foi possível porque esse sistema incorporou grande parte das propostas formuladas nos governos anteriores.

SACHS sintetiza os princípios sobre os quais se apoiava a política nacional de habitação instituída pela Lei 4.830/64 em cinco pontos principais: prioridade para construção de habitação novas, chaves na mão, como acesso à propriedade privada em detrimento à habitação de aluguel; autonomia financeira do sistema por meio do recobrimento dos custos pelos devedores, e financiamento das operações mediante

\footnotetext{
${ }^{41}$ AZEVEDO, Sérgio e ANDRADE, Luís Aureliano Gama de. Op. Cit., 1982, p. 53. A expressão é de um antigo funcionário do BNH em entrevista aos autores, demonstrando o clima de hostilidade reinante contra a FCP por ocasião do Golpe de 1964.

42 BOLAFFI, Gabriel. Op. Cit. 1982, p. 42

${ }^{43}$ Cf. AZEVEDO, Sérgio e ANDRADE, Luís Aureliano Gama de. Op. Cit. 1982, p. 59.
} 
poupança compulsória e voluntária; indexação integral da poupança e das dívidas de modo a eliminar os efeitos da inflação; operação dos recursos realizada pelo setor financeiro privado e produção habitacional também realizado exclusivamente pelo setor privado; e centralização dos recursos financeiros e do sistema institucional, cabendo sua execução aos Estados e municípios ${ }^{44}$.

O SFH tinha por meta resolver o problema do "déficit habitacional" brasileiro ${ }^{45}$, de modo a "facilitar e promover a construção e a aquisição da casa própria, especialmente pelas classes de menor renda da população" ${ }^{\prime 4}$. A viabilização dos programas do sistema se deu por meio da constituição de um órgão com capacidade financeira, o $\mathrm{BNH}^{47}$.

O BNH tornou-se o real articulador do sistema, ao qual toda a política habitacional acabou subordinada. O SERFHAU, que deveria ser o grande órgão articulador do sistema, coordenando os programas e ações no campo do desenvolvimento urbano, acabou por se tornar um apêndice do banco. Na realidade o que se verificou foi que toda a política urbana acabou subordinada à política habitacional, ficando todo o desenvolvimento urbano atrelado à lógica do atendimento à demanda por moradia, o que acabou por tornar a construção de unidades o objetivo central do sistema, em lugar da construção de bairros inseridos na malha urbana, ficando a produção avaliada por critérios meramente quantitativos $^{48}$.

${ }^{44}$ Cf. SACHS, Céline. Op. Cit. 1999, p. 130.

${ }^{45}$ BOLAFFI, Gabriel. Op. Cit. 1982. Gabriel Bolaffi questiona o conceito de déficit habitacional, ao menos no caso brasileiro, por se tratar de uma economia de mercado. Sob seu ponto de vista, o número de habitações corresponderia exatamente à demanda financeiramente solvável, como qualquer outra mercadoria. Mais preciso seria trabalhar com o conceito de "carência" de habitações, o que levaria ao questionamento de por que, então, não é atacado especificamente o problema da renda insuficiente para a aquisição da moradia, ao invés da produção habitacional em si.

${ }^{46}$ Lei Federal 4.380, de 21 de agosto de 1964, art $8^{\circ}$. No próprio enunciado da lei que criou o SFH, o BNH e o SERFHAU observa-se a priorização do estabelecimento de uma política habitacional voltada à aquisição da casa própria, abandonado-se as possibilidades de locação habitacional, que haviam sido largamente utilizadas pelos IAPs.

${ }^{47}$ Em seu artigo 17 a lei 4.380 define como finalidades do BNH:

I. orientar, disciplinar e controlar o sistema financeiro da habitação;

II. incentivar a formação de poupanças e sua canalização para o sistema financeiro da habitação;

III. disciplinar o acesso das sociedades de crédito imobiliário ao mercado nacional de capitais;

IV. manter serviços de redesconto e de seguro para garantia das aplicações do sistema financeiro da habitação e dos recursos a ele entregues;

V. manter serviços de seguro de vida de renda temporária para os compradores de imóveis objeto de aplicações do sistema;

VI. financiar ou refinanciar a elaboração e execução de projetos promovidos por entidades locais de conjuntos habitacionais, obras e serviços correlatos;

VII. refinanciar as operações das sociedades de crédito imobiliário;

VIII. financiar ou refinanciar projetos relativos à instalação e desenvolvimento da indústria de materiais de construção e pesquisas tecnológicas, necessárias à melhoria das condições habitacionais do país..

${ }^{48}$ Cf. ROYER, Luciana. Op. Cit., 2002, p. 11. 
$\mathrm{O}$ BNH foi criado com capital inicial de $\mathrm{Cr} \$ 1$ bilhão, com recursos adicionais provenientes de contribuição a ser cobrada das empresas mediante o pagamento de $1 \%$ sobre o montante da folha de pagamento das mesmas, de todos os empregados regidos pela $\mathrm{CLT}^{49}$.

O BNH tinha por seu objetivo principal reduzir, ou mesmo acabar com o "déficit habitacional" no Brasil, por meio da produção de novas moradias, buscando otimizar os recursos ao integrar e coordenar as ações governamentais, produzindo uma redução do preço da habitação, através da expansão da oferta, assim como a melhoria das condições sanitárias da população.

Além dessa função precípua ao objetivo central do banco, ele também tinha como meta ser um agente econômico de peso, fortalecendo, dinamizando e consolidando a indústria da construção civil no país, de materiais de construção e de bens de consumo duráveis. Outro objetivo, relacionado diretamente ao anterior, dizia respeito ao aumento da oferta de empregos, especificamente para mão-de-obra não-especializada.

A constituição do BNH apresentou algumas novidades em relação às estruturas concebidas anteriormente: primeiro, por tratar-se de um banco, enfocando o problema financeiro envolvido na questão; segundo, por introduzir mecanismos de correção monetária relativas às perdas inflacionárias; e terceiro, pela tentativa de articular o poder público ao setor privado, efetivo operador das políticas habitacionais. Esse modelo pressupunha a completa eliminação de subsídios, como os existentes no modelo anterior, da FCP; a idéia de que o setor privado possuía uma capacidade administrativa superior ao do setor público; e efetivava uma grande centralização normativa acompanhada de uma descentralização executiva.

Essa concepção do BNH para o enfrentamento da questão habitacional por meio de uma "racionalidade econômico-administrativa de tipo empresarial", que se autosustentasse, não impondo ônus adicionais à Fazenda Nacional e recuperando integralmente os capitais investidos já carregava de partida as contradições que mais tarde ficariam claras na impossibilidade da resolução dos problemas de moradia das camadas de mais baixa renda por meio de uma estrutura com esse perfil ${ }^{50}$.

Devido ao mecanismo da correção monetária, que incidia sobre as prestações do financiamento da casa própria em níveis superiores ao dos reajustes dos salários, era

\footnotetext{
${ }^{49}$ Lei Federal 4.380, de 21 de agosto de 1964, art 22.

${ }^{50}$ Cf. AZEVEDO, Sérgio e ANDRADE, Luís Aureliano Gama de. Op. Cit. 1982, p. 61-62.
} 
comum que os valores e, em decorrência, os prazos dos financiamentos, aumentassem consideravelmente, por períodos não raro excessivamente longos.

A lógica empresarial da política habitacional sob a regência do $\mathrm{BNH}$ exigia a execução de aplicações rentáveis ao banco. Segundo MARICATO

\begin{abstract}
a necessidade de investir de forma rentável forçou o BNH a buscar clientes com capacidade para fazer frente às dívidas corrigidas com juros e correção monetária fixados pelo banco. Em 1969, a política de habitação popular tinha se revelado o mais completo fracasso, devido ao total descompasso entre os rendimentos da clientela popular (e sua lenta velocidade de correção) e as dívidas relativas ao financiamento da casa própria (e sua acelerada velocidade de correção) (...)
\end{abstract}

Recursos não faltavam ao BNH. Faltavam clientes com estatura financeira para responder às regras do jogo ${ }^{51}$.

Para evitar distorções desse tipo, em 1967 havia sido criado o FCVS - Fundo de Compensação das Variações Salariais, a fim de estabelecer limites para a dilatação dos prazos de resgate das dívidas. Esse fundo deveria cobrir eventuais alongamentos dos prazos resultado do crescimento das dívidas dos mutuários, assumindo a responsabilidade pelo saldo devedor. Com isso estabelecia-se um reconhecimento tácito de que era inviável uma solução estritamente empresarial para o enfrentamento das demandas habitacionais para as populações de baixa renda, sendo necessária alguma forma de subsídio. Contudo, da forma como foi instituído, o FCVS permitia o subsídio de parte dos saldos devedores não apenas das camadas populares, mas também de alguns setores médios contratantes de financiamentos habitacionais do $\mathrm{BNH}^{52}$.

BOLAFFI sustenta que a definição da "habitação popular" como "problema fundamental do país", longe de ser um objetivo real de melhoria das condições habitacionais das classes de baixa renda, "não passou de um artifício político formulado para enfrentar um problema econômico conjuntural"53.

Para BOLAFFI a conjuntura econômica recessiva, em especial do período 19641968, levou à constituição do sistema e a priorização da habitação popular enquanto política de Estado. Essa ação estatal buscava os efeitos multiplicadores desse tipo de investimento, reativando a economia por meio da geração de empregos, sobretudo para mão-de-obra não qualificada (que é intensiva na indústria da construção civil) e no estímulo à atividade industrial por meio da dinamização da indústria da construção civil. Contudo, esses "efeitos multiplicadores" são baixos nos setores industriais de base da construção

\footnotetext{
${ }^{51}$ MARICATO, Ermínia. Política habitacional no regime militar: do milagre brasileiro à crise econômica. Petrópolis: Vozes, 1987, p. 38.

${ }^{52}$ Cf. AZEVEDO, Sérgio e ANDRADE, Luís Aureliano Gama de. Op. Cit. 1982, p. 69-71.

${ }^{53}$ BOLAFFI, Gabriel. Op. Cit. 1982, p. 47.
} 
civil, como os setores produtores de materiais de construção, sendo pouco rentáveis e tendo pouco impacto na atividade industrial como um todo. Com a alteração no quadro econômico, a partir de 1967, os setores capital-intensivos da economia tornaram-se os grandes motores da reativação econômica ${ }^{54}$, e o investimento em habitação popular permaneceu no campo da retórica.

No ano de 1967 o BNH recebeu a gestão dos recursos do FGTS, tornando-se, a partir de 1969, "o segundo banco do país em termos de magnitude de recursos disponíveis, precedido apenas pelo Banco do Brasil”55. O FGTS foi constituído com a contribuição obrigatória de $8 \%$ sobre os salários dos trabalhadores, sendo instrumento destinado a "flexibilizar" a legislação trabalhista vigente, funcionando como uma espécie de "seguro desemprego", destinado a facilitar as demissões dos trabalhadores.

Os recursos do BNH provinham de duas fontes principais: a poupança voluntária captada pelas cadernetas de poupança, representada pelos recursos do SBPE - Sistema Brasileiro de Poupança e Empréstimo e a poupança compulsória dos trabalhadores, proveniente dos recursos do FGTS - Fundo de Garantia por Tempo de Serviço. Em tese, os recursos deste deveriam ser destinados ao atendimento às demandas habitacionais das camadas de menor renda (um a três salários mínimos, mais tarde estendidos até cinco salários mínimos) e daquela ao financiamento das camadas de renda média.

Por meio desses exitosos mecanismos de captação de recursos o sistema, gerido pelo BNH como órgão central, atingiu resultados expressivos, ultrapassando suas expectativas. Em seus 22 anos de existência, entre 1964 e 1986, o BNH financiou 4,8 milhões de moradias, significando praticamente $25 \%$ de todo o incremento no número de residências construídas no período, ainda que não mais de $20 \%$ desse contingente representasse produção de moradia para população de baixa renda. O banco chegou a

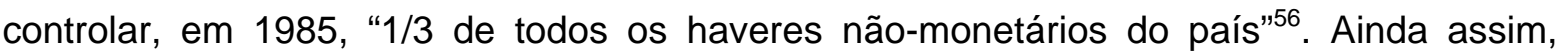
nesse período verificou-se um incremento expressivo no número de favelas e loteamentos clandestinos.

Isso ocorreu porque grande parte dessa produção imobiliária acabou orientada para o atendimento à demanda das classes média e alta, privilegiada em detrimento do atendimento às classes de mais baixa renda. A utilização dos recursos oriundos do FGTS dos trabalhadores, com juros de remuneração abaixo dos níveis praticados pelo mercado

\footnotetext{
${ }^{54}$ Siderurgia, borracha, máquinas e equipamentos, material elétrico e eletrônico etc.

${ }^{55}$ BOLAFFI, Gabriel. Op. Cit., 1982, p. 42.

${ }^{56}$ CHAFFUN, Nelson. Op. Cit., 1997, p. 26
} 
para a produção imobiliária de classe média, constituiu-se num "expediente concentrador de renda"57.

Segundo dados do próprio BNH, apesar da considerável soma de recursos destinados à produção imobiliária, no ano de 1971, por exemplo, "os recursos utilizados pelo Sistema Financeiro da Habitação só foram suficientes para atender 24 por cento da demanda habitacional (urbana)"58, o que significa que, nesse ano, o atendimento situou-se muito aquém do crescimento da demanda verificada.

O próprio banco reconheceu o fracasso no enfrentamento à carência habitacional das camadas de mais baixa renda, o que levou ao lançamento, em 1973, do PLANHAP Plano Nacional de Habitação Popular, repetindo os mesmos objetivos do BNH e do SFH quando de sua constituição. A partir de 1976, essa reorientação passa pelo "revigoramento" das COHABs, que viriam a ser os instrumentos para a produção de habitações destinadas à faixa de renda entre 1 e 5 salários mínimos ${ }^{59}$.

Segundo BOLAFFI, a questão que deve ser colocada a respeito do BNH é que se ele não estava atingindo seus objetivos enunciados, e aparentemente nem pretendia atingilos, quais os reais objetivos do $\mathrm{BNH}$ ?

A política habitacional desenvolvida pelo $\mathrm{BNH}$ se, por um lado, visava o atendimento às demandas habitacionais existentes, por outro se configurou como ferramenta econômica de atendimento às demandas do capital, ao oferecer parte considerável dos recursos do "fundo público à dinamização de setores da iniciativa privada"60, uma vez que essa política pública alicerçava-se na operação por meio de agentes privados, sendo o banco o agente financeiro do sistema. $O$ banco limitava-se a arrecadar recursos financeiros para posteriormente repassá-los a uma miríade de agentes privados.

Dessa forma, o BNH produziu efeitos consideráveis enquanto alavanca econômica, embora contraditórios com seus objetivos manifestos. Ao transmitir suas funções e a operação da política aos agentes privados o banco de uma

poderosa alavanca para a elevação do nível de vida das populações urbanas que poderia ter sido (...) se transforma num funil por meio do qual recursos do FGTS (...) são drenados para o setor privado para alimentar o mecanismo da acumulação.

\footnotetext{
${ }^{57}$ MARICATO, Ermínia. Op. Cit., 1996, p. 44.

${ }^{58}$ BNH. Relatório Anual, 1971 apud BOLAFFI, Gabriel. Op. Cit., 1982, p. 53.

59 MARICATO, Ermínia. Op. Cit., 1987, p. 42.

${ }^{60}$ ROYER, Luciana. Op. Cit., 2002, p. 10.

${ }^{61}$ BOLAFFI, Gabriel. Aspectos Socioeconômicos do Plano Nacional de Habitação. Tese de doutoramento apresentada à FAUUSP. São Paulo, 1972, apud ROYER, Luciana. Op. Cit., 2002, p. 9.
} 
Assim, o banco atuava, ao mesmo tempo, de um lado, no financiamento à produção, e do outro lado, ao consumo imobiliário. MARICATO identifica o BNH como peça fundamental na "estruturação e consolidação de um mercado imobiliário urbano capitalista"62 no Brasil. Segundo ela, os recursos do Sistema Financeiro da Habitação empregados no financiamento à habitação, ao saneamento básico e à infra-estrutura urbanos alterou drasticamente a configuração das cidades brasileiras, na promoção à verticalização das áreas mais centrais das cidades; no aumento especulativo do solo urbano; na dinamização da promoção e construção imobiliária; na diversificação da indústria de materiais de construção; no subsídio às moradias de classe média; e na consolidação das grandes empresas da construção civil.

Apesar disso, as cidades brasileiras assistiam à expansão, em ritmo acelerado, de vastos setores urbanos, nos loteamentos periféricos e nas favelas, geradas pela manutenção ou desenvolvimento de formas não-capitalistas de produção da habitação, baseadas na auto-construção.

Alguns autores dividem a atuação do BNH em fases distintas, conforme as características da forma como se deu o enfrentamento das questões relativas à produção habitacional, variando conforme o contexto político e socioeconômico ao longo de seus 22 anos de existência. SACHS utiliza a classificação desenvolvida por VALLADARES ${ }^{63}$ que, a partir dos diversos trabalhos existentes, identifica quatro fases com perfis distintos de atuação.

A primeira fase corresponde ao período 1964 a 1967, momento de implantação e estruturação do $\mathrm{SFH} / \mathrm{BNH}$, momento este marcado pela escassez de recursos, situação que vai se alterar drasticamente com a criação do FGTS, em 1966, e do SBPE, em 1967, que passarão a prover o BNH dos recursos necessários à implementação de uma efetiva política habitacional e urbana. A essa fase corresponde um momento de experimentação dos mecanismos e instrumentos a serem largamente aplicados posteriormente.

A segunda fase, de 1967 a 1971, representou um alargamento de suas funções originais, ocorrendo uma participação cada vez maior dos setores de mais alta renda nos financiamentos concedidos pelo banco. Esse alargamento do campo de ação do BNH traduziu-se numa participação maior do banco no financiamento à infra-estrutura urbana, orientada pela criação do FINASA - Programa de Financiamento para o Saneamento, em 1968 e do PLANASA - Plano Nacional de Saneamento, dois anos depois.

\footnotetext{
${ }^{62}$ MARICATO, Ermínia. Op. Cit., 1996, p. 44.

63 VALLADARES, Lícia. Estudos Recentes sobre a Habitação no Brasil: Resenha da Literatura. in VALLADARES, Lícia. (Org.) Repensando a Habitação no Brasil. Rio de Janeiro: Jorge Zahar, 1983.
} 
A terceira fase, no período de 1971 a 1979, "corresponde à transformação do BNH numa empresa pública que assumia as funções de um banco de segunda linha"64. Nesse momento, o BNH se consolida como agente financeiro, atuando por meio de um sistema de órgãos privados e públicos, responsáveis pela concessão dos empréstimos e do contato com o público, recebendo comissões por esses serviços.

Nesse período intensificam-se os programas de desenvolvimento urbano com a criação de diversos fundos regionais de desenvolvimento e o lançamento, no ano de 1972 , do projeto CURA, programa destinado à renovação urbana. Esse projeto

financiou a desapropriação e/ou aquisição de terrenos para implantar projetos de habitação, investimentos em vias públicas, reestruturação ou extensão das redes de eletricidade, de iluminação pública, de água potável, de drenagem e de comunicação, equipamentos comunitários e trabalhos de gestão do projeto ${ }^{65}$.

Por diversas vezes, os efeitos do projeto acabaram resultando em valorização da terra urbana, alimentando a especulação imobiliária e levando à expulsão da população de menor renda, com conseqüente atração da classe média para as áreas objeto de intervenção, como no caso das obras do Metrô de São Paulo.

O BNH passou a se comportar cada vez mais como um "banco de desenvolvimento urbano". O nível de empréstimos para habitação caiu de 93,2\%, em 1969, para $64,8 \%$, em 1979 , ao passo que o financiamento para obras de infra-estrutura e saneamento representaram, nesse mesmo ano, $29 \%$ do total de empréstimos do banco ${ }^{66}$.

A quarta fase tem início em 1979 e vai até sua extinção, em 1986, e representa um momento de transformação na postura das políticas públicas relativas à questão da habitação popular, relacionadas diretamente ao momento de abertura política e de busca de legitimidade pelo governo, num contexto de fortalecimento dos movimentos sociais urbanos. O BNH procurou reorientar suas ações de modo a atingir setores com renda até 3 salários mínimos, marginalizados que vinham sendo pelas ações do banco.

Foram constituídas "soluções marginais ao sistema, visando reduzir as despesas no processo de produção" ${ }^{2}$, cujo objetivo era o de atingir os segmentos de menor renda. Esses programas ficaram conhecidos como reformistas ${ }^{68}$, por procurarem reorientar a

\footnotetext{
${ }^{64}$ SACHS, Céline. Op. Cit., 1999, p. 145.

${ }^{65}$ SACHS, Céline. Op. Cit., 1999, p. 145.

${ }^{66}$ SACHS, Céline. Op. Cit., 1999, p. 146.

${ }^{67}$ ROYER, Luciana. Op. Cit., 2002, p. 13.

68 O BNH abandonava sua concepção inicial de enfrentamento da carência habitacional por meio da produção em massa, industrial, de grandes conjuntos, que havia orientado as políticas habitacionais até este momento. Os programas reformistas representam a segunda geração de programas de habitação
} 
atuação do BNH para o objetivo a que ele havia sido originalmente criado. Esses programas foram, pela ordem cronológica de criação: Profilurb ${ }^{69}$ (1975); Promorar $^{70}$ (1979) e João-de-Barro ${ }^{71}$ (1984).

O BNH estruturava-se financeiramente sobre os recursos advindos de duas fontes principais: a poupança compulsória, representada pelo FGTS, e a poupança voluntária, representada pelo SBPE. O BNH deveria funcionar com ampla autonomia financeira, pois de um lado tinha canalizados para seu fundo esses recursos e, de outro, o pagamento dos empréstimos indexados à inflação através do mecanismo da correção monetária. Esse dois mecanismos mostraram sua fragilidade no período de crise econômica de 1981-1983, momento de aceleração inflacionária, acompanhada de compressão dos salários.

Nesse contexto econômico turbulento, o aumento dos níveis de desemprego levou a uma grande retirada de recursos do FGTS; por outro lado, empresas em dificuldades passaram a atrasar ou simplesmente deixaram de recolher o Fundo de Garantia de seus funcionários, levando à redução no nível de crescimento do FGTS;

social, surgindo de uma reavaliação dos programas até então vigentes, como alternativa de superação aos impasses da política habitacional. Essas propostas trouxeram uma nova maneira de encarar a urbanização e a habitação "espontâneas" e uma nova relação entre o poder público e as comunidades urbanas.

${ }^{69}$ O Profilurb - Programa de Financiamento de Lotes Urbanizados consistia na produção de loteamentos populares, com lotes demarcados e infra-estrutura básica implantada. O programa básico foi modificado em 1978, permitindo a implantação de embrião no lote. Esse programa teve sua origem na preocupação em se constituir uma alternativa viável de loteamento popular a fim de conter o crescimento das favelas. Um dos grandes problemas apontados na implantação do programa foi a falta de coordenação entre os agentes promotores (prefeituras, COHABs, concessionárias de serviços públicos etc), acarretando problemas no resultado final dos loteamentos, da escolha de terrenos inadequados ao parcelamento urbano do solo, a problemas na implantação da infra-estrutura, tudo isso resultando em encarecimento dos lotes. "Até o final de 1980, apenas 43 mil lotes urbanizados foram instalados (...). Assim sua participação nos contratos do BNH nunca foi significativa. No entanto, constitui uma etapa na evolução dos modos de intervenção do BNH"' Cf. SACHS, Céline. Op. Cit., 1999, p. 151.

${ }^{70}$ O Promorar - Programa de Erradicação da Subabitação foi criado em 1979, para substituir o Profilurb, mas diferindo deste numa questão central: seu objetivo era a urbanização de favelas, dotando-as de infra-estrutura e saneamento básico. Já a regularização fundiária dos núcleos de favela, também objeto do programa, teve grandes dificuldades em se concretizar. O programa realizava-se em parceria entre o $\mathrm{BNH}$, a quem cabia o suporte financeiro, e os governos estaduais e municipais, responsáveis por sua execução. O Promorar apresentou um caráter altamente político, sendo os empréstimos diretamente vinculados ao calendário eleitoral. O grande interesse nesse programa reside no fato de que a política habitacional nacional reconhecia, enfim, a existência da favela e a necessidade de sua regularização, constituindo-se numa evolução em relação ao Profilurb.

71 O Programa João-de-Barro, criado em 1984, consistiu num programa de auto-construção assistida, voltado a famílias com renda inferior a 1,5 salários mínimos, significando a "institucionalização de práticas cotidianas da população urbana". Cf. ROYER, Luciana. Op. Cit., 2002, p. 15. Apesar da grande demanda existente por sua implementação, o número de unidades construídas foi irrisório, sendo mais importante seu caráter simbólico que seus resultados práticos. Dois anos após a implantação do programa João-de-Barro o BNH foi extinto. 
paralelamente, pôde-se observar redução no nível de depósito nas cadernetas de poupança ${ }^{72}$.

Com o aumento do desemprego e a queda no poder aquisitivo dos salários, ocorreu um aumento na inadimplência no pagamento dos empréstimos do $\mathrm{BNH}$, "inclusive por parte das classes médias afetadas pela crise"73. O número de contratos com pagamentos em atraso de mais de 3 meses passaram de $10 \%$ do total, no período 1980 1981, para 25\% no fim do ano de 1984.

O mecanismo de ajuste dos pagamentos das dívidas em relação à inflação também se mostrou ineficiente em relação à escalada inflacionária do período. O SFH passou a acumular enorme dívida em relação "à diferença do montante devido, indexado sobre a inflação, e do valor real do que foi reembolsado"74.

O desequilíbrio do sistema demonstrou que o SFH necessitava de um ambiente de crescimento econômico contínuo para manter sua estabilidade. Nesses momentos de forte expansão econômica as contradições do SFH ficavam mascaradas pela poupança compulsória que compunha o fundo. A partir do momento em que se instalou um cenário de contração econômica, acarretando saques em massa ao FGTS, o sistema entrou em crise.

O golpe final ao BNH foi desferido pelo Plano Cruzado, em fevereiro de 1986. Com o intuito de debelar a inflação, implantou-se o congelamento de preços, acarretando na queda da rentabilidade da poupança. Esse fato provocou uma corrida às cadernetas, com retirada maciça de recursos. Esses recursos foram canalizados para o mercado imobiliário, acarretando grande especulação em relação ao valor dos imóveis.

Dessa forma, o BNH encontrou-se descapitalizado, com dívidas gigantescas, e que cresceram ainda mais quando da conversão dos contratos realizados em cruzeiros para a nova moeda, o cruzado.

Em 1986, após 22 anos de atividade, com um saldo de aproximadamente 4,4 milhões de habitações construídas - cerca de $25 \%$ de todo o incremento imobiliário residencial do período no Brasil - $\mathrm{O} \mathrm{BNH}$ foi extinto, tendo suas atribuições transferidas para a Caixa Econômica Federal.

\footnotetext{
${ }^{72}$ Cf. SACHS, Céline. Op. Cit., 1999, p. 137.

${ }^{73}$ SACHS, Céline. Op. Cit., 1999, p. 137.

${ }^{74}$ SACHS, Céline. Op. Cit., 1999, p. 138.
} 


\subsection{O Estado e a Produção dos Grandes Conjuntos Habitacionais}

Se, como visto, o Estado brasileiro apresentou motivações diversas - quer fossem econômicas ou político-ideológicas, quer objetivassem a intervenção na questão habitacional, ou fossem subterfúgio a justificar razões inconfessas - ainda é necessário compreender por que e de que modo essas políticas traduziram-se na produção de espaços urbanos constituídos pela repetição à exaustão de unidades habitacionais, representada por conjuntos habitacionais com escala, grau de inserção urbana e qualidade espacial variados. Assim como as grandes linhas das políticas habitacionais e urbanas brasileiras ao longo do século $\mathrm{XX}$, as motivações e objetivos da promoção pública sob a forma de conjuntos habitacionais também necessitam de avaliação.

Como já visto no capítulo anterior, as péssimas condições urbanas e habitacionais encontradas nas cidades européias na virada do século XIX para o XX produziram uma reflexão arquitetônica imbuída de compromissos políticos progressistas, que culminou no Movimento Moderno em Arquitetura, e que levou à formulação de propostas com o intuito de impor "ordem" ao que se identificava como "caos" nessas novas e grandes cidades industriais. De modo geral, essas propostas giraram sempre em torno da possibilidade de se definir limites à expansão das cidades, ou seja, até que ponto uma cidade poderia crescer sem comprometer a qualidade de vida de seus moradores.

Esse questionamento desembocou em duas perspectivas distintas na forma de encarar o desafio da construção da cidade contemporânea: de um lado, aqueles que propugnavam a reforma da cidade existente dentro de princípios racionais, de forma a torná-la compatível com as novas demandas do mundo industrial, tanto internamente ao seu tecido pré-existente quanto nas novas áreas de expansão; de outro lado, os que defendiam a necessidade da constituição de novos núcleos urbanos, novas cidades autônomas e afastadas dos núcleos urbanos pré-existentes, articulados com estes, mas econômica e administrativamente autônomos.

A defesa da constituição de novos núcleos urbanos autônomos estrutura-se, principalmente, a partir das idéias formuladas por Ebenezer Howard em seu livro Cidadesjardins de amanhã. Nesse texto ele lança as bases teóricas de uma comunidade utópica, perfeita e auto-suficiente, sendo a síntese entre campo e cidade. Howard afirma os benefícios da habitação unifamiliar como superior à desordem e promiscuidade das grandes cidades, procurando reunir "o máximo da ruralidade com a vida urbana", num núcleo auto-suficiente que tenta atingir o equilíbrio entre as atividades industriais e a 
agricultura $^{75}$. Estas idéias influenciaram decisivamente as propostas para a reconstrução das cidades européias no segundo pós-guerra, sobretudo na Inglaterra.

No Brasil a construção de cidades novas autônomas foi uma experiência limitada, ainda que significativa, mas de sentido absolutamente diverso do que se dava na Europa. Aqui o principal motivador da implantação de cidades-novas (aquelas que chegaram a contar com um plano amplo de ocupação e desenvolvimento urbano, ainda que a realidade tenha traído as intenções originais) correspondeu à criação de novas capitais administrativas, como Belo Horizonte, em 1893, Goiânia, em 1933, e Brasília, inaugurada em 1960. A última cidade brasileira criada para ser capital administrativa foi Palmas, em 1989, capital do Estado de Tocantins, objeto de concurso. Em comum, essas cidades têm o fato de negarem a realidade social do país que, apesar de planejadas pelo poder público, ignoraram por completo os segmentos pobres da população, que seguiram procurando sua solução de moradia em periferias precárias e distantes dos espaços de representação do poder aí implantados.

De forma geral, os casos de constituição de cidades novas no Brasil estiveram vinculados a empreendimentos empresariais voltados à colonização do território, bases para a produção de mercadorias com o objetivo de alcançar o mercado internacional. No começo do século $X X$, o oeste paulista e norte paranaense vêem surgir cidades novas decorrentes da expansão da agricultura exportadora cafeeira, como Marília e Londrina, em 1933, e Maringá, em 1951, tendo nascido e crescido mais "fruto de improvisações rápidas e não de uma planificação cuidadosamente preparada"76. Em período mais recente este processo se desenrolou, com características semelhantes, na fronteira agropecuária do norte do Mato-Grosso, com a implantação de cidades como SINOP, em 1975, que tem seu nome originado da sigla da empresa colonizadora que a fundou: Sociedade Imobiliária Noroeste do Paraná.

Distintamente, como produtos diretos do empreendimento que as originou, têm-se dois casos bastante emblemáticos: a Vila da Serra do Navio (tornada município em 1993, hoje com quase 4.000 habitantes), empreendimento voltado à exploração de uma jazida de manganês existente no interior do então Território do Amapá, tendo seu projeto sido encomendado ao Arq. Oswaldo Bratke em 1955, sendo destinada aos diretores e operários da mineradora ${ }^{77}$; e a cidade de Caraíba (na verdade, um distrito da cidade baiana de

\footnotetext{
${ }^{75}$ BENEVOLO, Leonardo. Op. Cit., 2006, p. 358-60

${ }^{76}$ BRUAND, Yves. Arquitetura Contemporânea no Brasil. São Paulo: Perspectiva, 1997, p. 345.

${ }^{77}$ Cf. SEGAWA, Hugo. Oswaldo Arthur Bratke. São Paulo: ProEditores, 1997, p. 235-296.
} 
Jaraguari), projeto do arquiteto Joaquim Guedes no sertão norte da Bahia, como suporte à indústria exploradora das jazidas de cobre da região ${ }^{78}$.

Dessa forma, não diferem do sentido que a colonização imprimiu à ocupação do território desde o século XVI, como identificou Caio Prado Jr., segundo o qual

nos constituímos para fornecer açúcar, tabaco, alguns outros gêneros; mais tarde ouro e diamantes; depois, algodão, e em seguida café, para o comércio europeu. Nada mais que isto. E com tal objetivo, objetivo exterior, voltado para fora do país e sem atenção a considerações que não fossem o interesse daquele comércio, que se organizarão a sociedade e a economia brasileiras. ${ }^{79}$

Dessa forma, as experiências na constituição de cidades novas, no sentido em que isto se deu na Europa, como forma de organização do território fortemente ligada ao enfrentamento dos problemas sociais, não encontrou paralelo no Brasil. Contudo, as intervenções estatais de caráter "reformista", objetivando a transformação e expansão das cidades pré-existentes, especificamente sob a forma de conjuntos habitacionais, foram implantadas em escala significativa, tanto quantitativa quanto qualitativamente. São as características dessa intervenção sob a forma-conjunto que nos interessam estudar aqui, tanto em relação ao modo como essas idéias foram introduzidas no Brasil, quanto de que forma podem ter contribuído no enfrentamento das demandas por moradia das classes populares.

A atuação estatal sob a forma da produção de conjuntos habitacionais no Brasil foi bastante influenciada pelas experiências européias do entreguerras, sobretudo nas Siedlungen alemãs e nos Höfe vienenses. A incorporação desses princípios se deu, contudo, de forma parcial e limitada, desenrolando-se num progressivo empobrecimento programático e formal entre as pioneiras experiências desenvolvidas pelo IAPI - Instituto de Aposentadorias e Pensões dos Industriários nos anos 1940 e os grandes conjuntos implantados sob a égide do $\mathrm{BNH}$, principalmente a partir dos anos 1970, degringolando num "suposto racionalismo formal desprovido de conteúdo, consubstanciado em projetos de péssima qualidade, monótonos, repetitivos, desvinculados do contexto urbano e do meio físico e, principalmente, desarticulados de um projeto social”80.

Algumas ações estatais visavam claramente integrar e ajustar as camadas de baixa renda dentro de um projeto articulado ao desenvolvimento brasileiro, necessário à expansão capitalista nacional, com forte conteúdo moral e "pedagógico":

\footnotetext{
${ }^{78}$ Cf. CAMARGO, Mônica Junqueira de. Joaquim Guedes. São Paulo: Cosac \& Naify, 2000, p. 100-109.

${ }^{79}$ PRADO JR., Caio. Formação do Brasil Contemporâneo. São Paulo: Brasiliense, 2007, p. 31-2.

${ }^{80}$ BONDUKI, Nabil. Op. Cit., 1998, p. 135.
} 
A partir de 1940, a Prefeitura do Distrito Federal (RJ) intensifica um programa de erradicação de favelas, criando os 'Parques Proletários Provisórios' numa visão autocrática de 'reeducar, reajustar, e recuperar o morador, integrando-o novamente na sociedade como elemento útil e produtivo. ${ }^{81}$

Diversos arquitetos do período enxergaram na habitação social um meio

para modificar as condições da classe trabalhadora, introduzindo novos hábitos e um modo de vida 'moderno' que romperiam com o atraso do país, expresso no subdesenvolvimento, na ignorância, na injustiça social e nas práticas de produção atrasadas e de baixa produtividade. ${ }^{82}$

A visão acerca da missão pedagógica da arquitetura moderna para as classes populares como meio de integrá-las à sociedade capitalista como elemento produtivo transparece na fala de inúmeros arquitetos e engenheiros das décadas de 1930 e 40, inclusive daqueles portadores de ideais os mais progressistas.

Para Lúcio Costa a aplicação dos preceitos modernos às novas habitações proletárias traria grandes transformações à sociedade, sendo fundamental na libertação dos trabalhadores: "As facilidades modernas diminuiriam a necessidade de empregados domésticos, que passariam a trabalhar nas indústrias"83.

Mas para isso seria necessário educar as massas sobre como utilizar essas novas "máquinas de morar". Para a engenheira Carmen Portinho, responsável pela construção do Conjunto Pedregulho, "a mais importante tarefa (das assistentes sociais) era ensinar aos mais pobres novos hábitos de higiene, saúde e, principalmente, como 'usar' as construções modernas." ${ }^{84}$.

Portinho acreditava ainda que a habitação deveria ser

um serviço social de utilidade pública, com a principal função de reeducação completa do operário brasileiro, que (...) deveria estar incluída entre os serviços obrigatórios que o governo deve oferecer, como água, luz, gás, esgoto etc. ${ }^{85}$

Mais do que apenas prover condições mínimas de habitabilidade às massas urbanas, a base ideológica que estruturava o pensamento a partir do qual se propunha o conjunto como a solução habitacional ideal ao proletariado brasileiro parte do pressuposto

\footnotetext{
${ }^{81}$ FINEP/GAP. Habitação Popular: inventário da ação governamental. São Paulo: FINEP, Projeto, 1983, p. 54.

82 BONDUKI, Nabil. Op. Cit., 1998, p. 138.

${ }^{83}$ CAVAlCANTI, Lauro. Casas para o Povo. Dissertação de Mestrado apresentada ao Museu Nacional. Rio de Janeiro: mimeo, 1987, apud BONDUKI, Nabil. Op. Cit., 1998, p. 139.

${ }^{84}$ BONDUKI, Nabil. Op. Cit., 1998,, p. 139.

${ }^{85}$ CAVALCANTI, Lauro. Op. Cit., 1987, p. 69 apud BONDUKI, Nabil. Op. Cit., 1998, p. 140.
} 
da necessidade premente da "reeducação completa do operário brasileiro". Attílio Corrêa Lima, arquiteto responsável por algumas das propostas mais interessantes e de maior qualidade para conjuntos habitacionais desse período expõe seu pensamento acerca das vantagens da aplicação dos preceitos modernistas para os novos conjuntos habitacionais em seu parecer sobre o Plano para a Cidade Operária da FNM - Fábrica Nacional de Motores, em Xerém, e sua superioridade frente à casa isolada, que

Recai no velho sistema de quintal, depósito de velharias, com aspecto árido e sórdido dos terreiros que (...) lembram o pijama e o chinelo dos domingos (imagens do velho, de um modo de vida arcaico) ao passo que as construções feitas em série, formando conjuntos densos, apresentam as mesmas vantagens da produção industrial em massa, baixam o custo unitário permitindo elevar o padrão da unidade de habitação e criar o parque coletivo de grandes proporções (...), com uma vida social diferente, com campo de esporte junto à porta, que trará o gosto pela camisa esporte. $^{86}$

Dessa forma, torna-se evidente o objetivo de uma certa arquitetura moderna de implantar um conjunto doutrinário direcionado a "reeducar" as camadas populares, adaptando-a às novas exigências do mundo moderno. Segundo Lauro Cavalcanti afirma em sua tese Casas para o Povo:

É minha hipótese estar a arquitetura moderna inserida em um movimento mais amplo de intelectuais brasileiros que assumem postura intervencionista ou domesticadora em relação às camadas populares. ${ }^{87}$

Pelas passagens anteriores depreende-se um amplo esforço, nesses primórdios da implantação do Modernismo no Brasil, pela transformação do país de eminentemente agrário em uma nação industrializada, das populações originalmente rurais em massas de operários para a indústria florescente. RECAMÁN vai identificar na transposição ideológica do Modernismo ao Brasil um processo que prescinde de uma "realidade produtiva concreta" $^{\text {"88 }}$, inversamente à condição européia em que este foi formulado. Mais que isso, constitui-se no arcabouço ideológico que se antecipa e vai servir à industrialização da Nação sob a condução do regime autoritário do Estado Novo. Desse modo, no Brasil

a Ideologia Arquitetônica realiza-se já como ideologia, tendo já superado seu estágio funcionalista de planificação totalizadora, se aqui considerarmos o esquema de Manfredo Tafuri sobre a falência da Ideologia do Plano. (...)

\footnotetext{
${ }^{86}$ LIMA, Attílio Corrêa. Parece sobre o plano da cidade operária da FNM (24.08.43). in Arquitetura 14 , agosto de 1963, p. 6-7 apud BONDUKI, Nabil. Op. Cit., 1998, p. 141.

${ }^{87}$ CAVAlCANTI, Lauro. Op. Cit., 1987, p. 63 apud BONDUKI, Nabil. Op. Cit., 1998, p. 142.

88 RECAMÁN, Luiz. Forma sem Utopia (mimeo), 2003, p. 2. Artigo acessado e baixado do site "http://www.la2.com.br/textos.html".
} 
No Brasil, aliviada de tal sobrecarga utópica, a arquitetura moderna pôde realizarse, pondo à mostra seu formalismo original. A forma arquitetônica moderna realizase no Brasil, e "deixa de enganar". 89

Assim, a chegada ao Brasil do ideário modernista já se dá num contexto de abandono de suas utopias de radical transformação social para se tornar um instrumento funcional na modernização do país.

Até esse momento, contudo, os modelos predominantes de provimento de habitação social, sob o aspecto eminentemente formal, eram a vila, composta em geral por casas geminadas dispostas em renque, e a casa isolada no centro do lote, formas já tradicionais e, sobretudo esta última, melhor aceitas e desejadas em relação às soluções de caráter coletivizante. A implantação dos conjuntos de perfil modernista, que vieram alterar a concepção e a configuração das cidades brasileiras, intervindo diretamente nos valores da população no que se refere à sua moradia, não teria sido possível sem uma intervenção direta e decisiva por parte do Estado; nesse caso, por meio da atuação dos Institutos de Aposentadorias e Pensões. Assim, "os objetivos de ordem, controle, subordinação etc., tão característicos da visão estado-novista, encontraram nesses núcleos habitacionais de inspiração moderna o espaço propício para sua difusão"90.

Não só a unidade habitacional como toda uma ampla e complexa gama de equipamentos e serviços fazia parte dos programas e projetos dos conjuntos desse período, dentro da visão de transformação e educação do morador desses espaços. Dessa forma,

concretizava-se nesses núcleos o ideal de proteção e controle do trabalhador, com a criação de um espaço totalizador, onde o tempo livre era ocupado em atividades educacionais e recreativas controladas pelo Estado que, ademais, era o locador das moradias. A imagem paternalista do Estado atingia seu ápice ${ }^{91}$.

Dentre os IAPs, o que mais se aprofundou nas pesquisas formais nos projetos dos conjuntos foi o IAPI, com grande influência das experiências das Siedlungen alemãs do entreguerras, tendo produzido, inclusive, o primeiro conjunto de grandes dimensões, o do Realengo, com 2.344 unidades, de autoria do Arq. Carlos Frederico Ferreira, e implantado entre fins da década de 1930 e 40.

Outros conjuntos que se destacam nesse período são o Conjunto Residencial Vila Guiomar, em Santo André, com 1.411 unidades, de autoria do mesmo arquiteto, com uma

\footnotetext{
${ }^{89}$ RECAMÁN, Luiz. Op. Cit., 2003, p. 3. Grifos no original.

${ }^{90}$ BONDUKI, Nabil. Op. Cit., 1998, p. 164.

${ }^{91}$ BONDUKI, Nabil. Op. Cit., 1998, p. 165-6.
} 
intensa preocupação urbanística; o Conjunto Residencial da Moóca, em São Paulo, com 576 unidades, de autoria do arquiteto Paulo Antunes Ribeiro, onde se utiliza o apartamento duplex pioneiramente num conjunto habitacional, antecipando uma solução que posteriormente seria utilizada em Pedregulho e no Japurá; o Conjunto Residencial da Baixada do Carmo, do Arq. Attílio Corrêa Lima, com 4.038 unidades previstas, mas apenas 480 executadas, com uma proposta de valorização dos espaços públicos, rompendo a estrutura do lote e promovendo (no projeto) um grande adensamento populacional da área, procurando diluir o custo elevado do terreno (localizado no centro da cidade de São Paulo) e com a implantação de inúmeros equipamentos de uso coletivo, como escola, creche, restaurante, cinema, hotel, etc. Todos esses conjuntos foram projetados e implantados pelo IAPI ao longo da década de 1940. O interesse e a preocupação com a qualidade e durabilidade dos conjuntos devem-se, sobretudo, ao fato de que as unidades nos mesmos eram alugadas, constituindo-se em patrimônio dos Institutos ${ }^{92}$.

Para BONDUKI, o exemplo mais bem acabado desse projeto integrando habitação social, modernização, educação popular e transformação da sociedade traduziuse na construção do Conjunto Residencial de Pedregulho, de 1947, onde à habitação agregaram-se diversos equipamentos sociais. Pedregulho constituiu-se no ápice desse processo e o melhor exemplo, no Brasil, da aplicação da concepção modernista da habitação como elemento organizador de uma nova cidade e de uma nova sociabilidade.

Segundo BONDUKI, a solução formal do conjunto remete às propostas de Le Corbusier para o Rio de Janeiro e Argel (1930). A influência corbusieriana também pode ser depreendida do partido adotado por Reidy sob inspiração da unité d'habitation, partido também utilizado por ele no Conjunto Marquês de São Vicente (Gávea), de 1952, objetivando a remoção de uma favela, ambos no Rio de Janeiro ${ }^{93}$.

Estes projetos foram desenvolvidos pelo DHP-DF - Departamento de Habitação Popular da Prefeitura da Cidade do Rio de Janeiro (então Distrito Federal), criado em 1946 pela Engenheira Carmen Portinho, que no ano anterior havia retornado da Inglaterra, onde havia trabalhado nos projetos de reconstrução das cidades inglesas destruídas pela guerra, e onde tomou contato com a discussão a respeito do problema da moradia popular ${ }^{94}$. $O$ DHP-DF, juntamente com os IAPs e a Fundação da Casa Popular, foram os órgãos

\footnotetext{
${ }^{92}$ Cf. BONDUKI, Nabil. Op. Cit., 1998, p. 158-191.

${ }^{93}$ Cf. BONDUKI, Nabil. Op. Cit., 1998, p. 170-171.

${ }^{94}$ Cf. BONDUKI, Nabil. Affonso Eduardo Reidy. Lisboa; São Paulo: Editorial Blau; Instituto Lina Bo e P. M. Bardi, 1999, p. 82.
} 
responsáveis pelas mais importantes propostas para a habitação popular entre as décadas de 1940 até meados dos ano 60.

O terreno escolhido para a implantação do conjunto Pedregulho, com $50.000 \mathrm{~m}^{2}$ de área e a 15 minutos de carro do centro da cidade, pertencia ao Departamento de Águas e Esgotos do Distrito Federal, para o qual este órgão previa a instalação de reservatórios para o abastecimento da Zona Norte. Quando este plano foi abandonado foi possível utilizá-lo para o conjunto ${ }^{95}$.

Para o estabelecimento do programa foi elaborado um amplo censo entre funcionários da Prefeitura do Distrito Federal com dados econômicos e familiares dos futuros moradores a fim de conhecer as demandas dessa população, resultando na seleção de 570 famílias. A proposta previa uma densidade média de 500 hab/ha, distribuídos em blocos habitacionais distintos: o bloco A, serpenteante na encosta do morro do Pedregulho contava com 272 unidades, duplex e de um pavimento, e foi concluído apenas em 1958; os blocos B (B1 e B2) contavam com 28 unidades duplex cada, e foram os primeiros a serem concluídos em 1950; e o bloco C, com 12 andares e 150 unidades duplex, que nunca foi construído ${ }^{96}$.

Além das unidades habitacionais, o programa previa escola primária para 200 crianças de 7 a 11 anos, ginásio esportivo, campo e piscina, posto de saúde, mercado e lavanderia coletiva automatizada, onde cada morador teria direito de lavar dois quilos de roupa por semana, incluídos no valor do aluguel. Previa-se, ainda um clube, nunca construído ${ }^{97}$.

A implantação de todos esses equipamentos se deve à definição de Reidy acerca da execução da obra. Ciente de que os equipamentos e serviços coletivos poderiam ser abandonados e jamais executados, o arquiteto optou por dar início à implantação do conjunto justamente por esses equipamentos (mercado, escola, ginásio e piscina), assim como os blocos habitacionais menores B1 e B2, imaginando que as grandes estruturas residenciais seriam executadas mais cedo ou mais tarde ${ }^{98}$. A experiência posterior dos grandes conjuntos promovidos pela COHAB-SP, onde a produção massiva de unidades habitacionais deixava a execução dos equipamentos coletivos a um futuro que nunca chegava, demonstra a justeza da percepção de Reidy.

\footnotetext{
${ }^{95}$ Cf. BRUAND, Yves. Op. Cit, , 1997, p. 230.

${ }^{96}$ Cf. BONDUKI, Nabil. Op. Cit., 1999, p. 83-4.

97 Cf. BONDUKI, Nabil. Op. Cit., 1999, p. 86-7. O conjunto teve projetados e executados painéis de Cândido Portinari, Anísio Medeiros e Burle Marx, este ultimo responsável também pelo projeto paisagístico de Pedregulho, pelos quais nenhum deles cobrou honorários profissionais (p. 99).

${ }^{98}$ Cf. BRUAND, Yves. Op. Cit., 1997, p. 225.
} 
À semelhança dos conjuntos do IAPI, e diferentemente daqueles da FCP, as unidades do Pedregulho eram alugadas, nesse caso aos funcionários da Prefeitura, mediante desconto consignado na folha de pagamento dos servidores, sendo a própria municipalidade a fiadora dos locatários.

A esse período de iniciativas incipientes na produção de conjuntos habitacionais com uma perspectiva de que a habitação era não só a unidade habitacional, mas um todo de equipamentos e serviços promotores de urbanidade - seguiu-se um momento de produção de conjuntos habitacionais de proporções muito maiores, viabilizados pelos recursos disponibilizados pelo $\mathrm{BNH}$. Como descrito anteriormente, o desenvolvimento urbano acabou atrelado à lógica do atendimento à demanda habitacional, tornando a construção de unidades habitacionais o objetivo central do sistema, em lugar da construção de bairros inseridos na malha urbana, ficando a produção avaliada por critérios meramente quantitativos, afastando-se definitivamente dos princípios originários daquele modernismo do período entreguerras.

Essas iniciativas estiveram articuladas à criação das COHABs - Companhias de Habitação em diversas cidades e que tiveram papel decisivo na produção habitacional em massa que se verificará nesse período, destinada a atender às demandas do "mercado popular". AZEVEDO e ANDRADE estabelecem uma periodização para definir a atuação das COHABs, de sua criação até o momento em que seu trabalho foi escrito, princípios dos anos 1980. Eles identificam três fases distintas: a primeira, de implantação e expansão (1964-1969); a segunda, de esvaziamento e crise (1970-1974); e a terceira, de restauração $(1975-1980)^{99}$.

$\mathrm{Na}$ primeira fase verificou-se a priorização do financiamento de imóveis para baixa renda, coerentemente com as diretrizes estabelecidas para a política habitacional pelo novo regime em busca de legitimação junto às camadas populares. Cerca de $40 \%$ das habitações financiadas (em número de unidades) pelo BNH nesse período destinaram-se a essa faixa de renda, totalizando 178.227 unidades, ainda dentro da concepção de que seria possível atendê-la sob a perspectiva da solução empresarial idealizada para o sistema ${ }^{100}$.

$\mathrm{Na}$ segunda fase verificou-se a perda de dinamismo das companhias, sendo financiados apenas 76.746 unidades para a baixa renda, um quinto do número de unidades financiadas para as camadas altas e médias. Isso pode ser explicado pela própria lógica do sistema empresarial sob a qual atuava o banco. Dessa forma, os recursos foram orientados

${ }^{99}$ Cf. AZEVEDO, Sérgio e ANDRADE, Luís Aureliano Gama de. Op. Cit., 1982, p. 89.

${ }^{100}$ Cf. AZEVEDO, Sérgio e ANDRADE, Luís Aureliano Gama de. Op. Cit., 1982, p. 90. 
para os segmentos médios, que apresentavam maior rentabilidade dos capitais investidos, permitindo juros mais altos, de 10\% a.a., enquanto o mercado popular "rendia" juros de 1 a 3\% a.a. Além disso, nessa época, este segmento apresentava altos índices de inadimplência.

A terceira fase apresenta um intenso revigoramento da atuação das COHABs, tendo sido financiadas no período de 1975-1980 um total de 749.911 unidades para o mercado popular. Isto pode ser explicado, principalmente, pela mudança nas regras de financiamento, cujo limite foi expandido até cinco salários mínimos, levando as Companhias a focar o atendimento no limite superior de renda do "mercado popular" nos novos conjuntos. Em segundo lugar a queda da inadimplência foi motivada, principalmente, pela substituição das populações de mais baixa renda por segmentos de classe média e média-baixa, por meio da compra das chaves por essas populações em melhor condição financeira ${ }^{101}$.

É interessante verificar, para além dos aspectos econômico-financeiros, que os períodos de maior expansão do atendimento dos estratos de mais baixa renda correspondem aos períodos de busca por legitimação do regime: nos anos iniciais do regime autoritário, e após a derrota eleitoral para o MDB em 1974, acompanhada do início da distensão do regime sob o governo Geisel.

DAMIANI também estabelece essa relação em sua tese de doutoramento, vinculando a construção dos grandes conjuntos habitacionais à distensão do regime autoritário, que buscava se legitimar e controlar os espaços populares, uma vez que estes grandes conjuntos foram, de modo geral, projetados e implantados durantes os Governos Geisel (1974-1979) e Figueiredo (1979-1985) ${ }^{102}$.

Já MARICATO identifica essa reorientação do BNH em direção às camadas populares com outros fatores, estreitamente vinculados ao setor da construção civil. Segundo ela o principal motivador dessa reorientação foi a exaustão do mercado imobiliário de alta e média rendas, que haviam encontrado seu limite nesse momento. Devido a isso o setor da construção civil - indústrias de materiais de construção, construtoras, etc - teria pressionado o $\mathrm{BNH}$ a orientar seus investimentos ao mercado

\footnotetext{
${ }^{101}$ Cf. AZEVEDO, Sérgio e ANDRADE, Luís Aureliano Gama de. Op. Cit., 1982, p. 89-100.

102 Cf. DAMIANI, Amélia. A cidade (des)ordenada: concepção e cotidiano do conjunto habitacional Itaquera I. Tese de doutorado apresentada à FFLCH/USP - Departamento de Geografia. São Paulo: FFLCH/USP, 1993, p. 72.
} 
popular; por outro lado, a emergência dos movimentos sociais urbanos pressionava o Estado no atendimento às suas reivindicações por moradia e infra-estrutura urbana ${ }^{103}$.

A Companhia Metropolitana de Habitação de São Paulo - COHAB-SP foi criada em 1965, por meio de lei municipal como uma sociedade anônima de economia mista, cujo principal acionista é a Prefeitura do Município de São Paulo. A partir desse período vão ser realizadas, pela COHAB, a construção dos grandes conjuntos habitacionais na periferia paulistana.

No fim dos anos 1970 ocorreu o último grande financiamento do $\mathrm{BNH}$, Cidade Tiradentes, maior complexo habitacional de produção pública da Região Metropolitana de São Paulo, um caso único tanto pela sua dimensão quanto pela sua desintegração urbana, segregação e exclusão social, composta por diversas partes fisicamente desconexas entre $\mathrm{si}^{104}$.

Cabe ressaltar que a este momento referido, da produção de grandes conjuntos pelas COHABs, a partir dos anos 1970, a grande quantidade de equipamentos públicos que eram parte integrante dos conjuntos dos IAPs é cortada ao mínimo. As promessas do movimento moderno de construção de um novo modo de vida a partir da habitação fracassam; de espaços de liberdade e transformação convertem-se em espaços de controle e alienação, por meio da aplicação de inúmeros preceitos modernistas como a padronização e a repetição. A produção massiva durante o período do BNH partia da concepção da habitação como "apenas tetos e nunca habitações urbanas - pela falta de equipamentos, serviços públicos, acesso, enfim, requisitos da vida urbana” ${ }^{105}$.

Como citado, a grande intervenção estatal no mercado popular de habitação não ocorreu no auge do "milagre econômico", mas quando este já fazia água, atuando, por um lado, como política econômica anticíclica e, por outro, como resposta às contradições sociais presentes na sociedade brasileira, e que se avolumavam com a crise do modelo vigente $^{106}$.

Para DAMIANI, a construção de grandes conjuntos era o exercício cotidiano de um

103 Cf. MARICATO, Ermínia. Op. Cit., 1987, p. 56-7. Como será visto no capítulo seguinte, dentre as razões que levaram à reorientação do BNH em direção às camadas populares por meio das COHABs, as determinações apontadas por Ermínia Maricato parecem ser as mais relevantes e cruciais.

${ }^{104}$ Cf. NAKANO, Kazuo. Op. Cit., 2002, p. 102.

105 MARTINS, Maria Lúcia Refinetti. BNH: limitaçõees e perspectivas. Trabalho Final de Graduação apresentado à Faculdade de Arquitetura e Urbanismo da Universidade de São Paulo. São Paulo: FAUUSP, 1974, p. 33.

${ }^{106}$ Cf. DAMIANI, Amélia. Op. Cit., 1993, p. 72, 74-5. 
'controle moral, social e político dos lugares de encontro', sobre o que pode significar essa produção do espaço, num país como o nosso, no momento em que se teimou em construção de grandes conjuntos. (...bem como) na redução do urbano a uma projeção aritmética das necessidades básicas de sobrevivência. ${ }^{107}$

Esse "controle moral, social e político" a que se refere DAMIANI pode ser constatado até mesmo na exploração dos pontos comerciais dentro do conjunto, de propriedade da COHAB, implantados nos locais estabelecidos pela $\mathrm{COHAB}$ e que só comercializavam produtos permitidos pela $\mathrm{COHAB}$, "que procura desta forma garantir a instalação daquilo que considera essencial para a população, ao mesmo tempo em que busca impedir a concorrência em um mesmo núcleo." ${ }^{108}$

Esse rígido controle exercido pela COHAB ainda trazia embutido muito da busca pela "reeducação", "reajuste" e "recuperação" do morador, de modo que este se integrasse à sociedade "como elemento útil e produtivo". A venda de bebida alcoólica no balcão dos estabelecimentos alugados pela $\mathrm{COHAB}$ foi, durante muito tempo, proibida nos conjuntos, sob pena de ser retomado o ponto comercial ${ }^{109}$.

O total controle exercido pelo órgão estatal, a COHAB, na vida do conjunto, da aprovação dos futuros mutuários, aos produtos passíveis de comercialização até a aprovação das atividades permitidas de serem desenvolvidas nos centros comunitários cedeu frente às próprias contradições dessa produção. A magnitude da escala dos conjuntos promovidos nessa fase da política habitacional acabou por inviabilizar o sistema: "O processo de controle (...) esgotou-se devido ao próprio tamanho dos conjuntos, que, maiores, tornavam-se incontroláveis"110.

\footnotetext{
107 DAMIANI, Amélia. Op. Cit., p. 186.

108 DAMIANI, Amélia. Op. Cit., p. 140.

${ }^{109}$ Cf. DAMIANI, Amélia. Op. Cit., 1993, p. 140.

${ }^{110}$ DAMIANI, Amélia. Op. Cit., 1993, p. 152.
} 
CAPÍTULO 3

CONJUNTOS HABITACIONAIS EM SÃO PAULO

EXPANSÃO URBANA E SEGREGAÇÃO SOCIOESPACIAL 


\subsection{São Paulo, expansão urbana e segregação socioespacial}

A fim de compreender de que modo se deu e o papel dos agentes atuantes no processo histórico de constituição do espaço metropolitano de São Paulo, nos apoiaremos, especialmente, nos trabalhos desenvolvidos por VILLAÇA ${ }^{1}$ e CALDEIRA ${ }^{2}$ com o intuito de traçar um histórico da formação do espaço urbano de São Paulo, procurando identificar as características e as relações estabelecidas entre a ocupação do território, o contexto político e social, e o ciclo econômico a que corresponde cada momento, dentro das leituras particulares de cada autor, permeadas por uma análise que procura identificar as características da localização e da segregação das classes sociais no território metropolitano.

CALDEIRA identifica três padrões de segregação socioespacial que se sucederam e se sobrepuseram na cidade de São Paulo: o primeiro padrão teria sido hegemônico do século XIX até meados dos anos 1940, quando as distintas classes sociais comprimiam-se num território exíguo e concentrado, separadas essencialmente pelo tipo de moradia; a partir da década de 1940 até aproximadamente 1980 foi hegemônico o padrão centro-periferia de segregação, no qual os distintos grupos encontram-se separados por grandes distâncias, residindo em áreas com níveis muito diferentes de infraestrutura; o terceiro padrão, surgido nos anos 1980 - e sobrepondo-se ao padrão centroperiferia - apresenta a proximidade de distintos grupos sociais, separados, porém, por muros e tecnologias de segurança, justificando-se pelo medo do crime violento, no qual os grupos sociais passam a não compartilhar mais os espaços na cidade. A autora denomina "enclaves fortificados" a esses "espaços privatizados, fechados e monitorados para residência, consumo, lazer e trabalho"3.

Contudo, a própria autora faz questão de afirmar que estes padrões de segregação dizem respeito a modelos de produção do espaço urbano, que se encontram e se sobrepõem em diversos trechos do território da cidade.

São Paulo permaneceu dentro de seus limites originais (o triângulo que tinha como vértices o Pátio do Colégio, o Mosteiro de São Bento e o Largo São Francisco) até a década de 1860. Entre 1870 e 1900 o crescimento da cidade que enriquecia com o café e se industrializava foi extremamente rápido.

\footnotetext{
${ }^{1}$ VILLAÇA, Flávio. Op. Cit., 2001.

${ }^{2}$ CALDEIRA, Teresa Pires do Rio. Op. Cit., 2000.

${ }^{3}$ CALDEIRA, Teresa Pires do Rio. Op. Cit., 2000, p. 211.
} 
Em fins do século XIX a cidade de São Paulo conheceu um crescimento vertiginoso, decorrência do afluxo de imigrantes europeus que acorriam à procura da riqueza produzida pela expansão cafeeira e das novas oportunidades geradas pela industrialização. Entre os anos de 1890 e 1940, apesar do crescimento demográfico explosivo, a urbanização não cresceu no mesmo ritmo, implicando num aumento das densidades habitacionais, que variaram de 83 hab/ha em 1881 para 110 hab/ha em 1914 . O bonde era o principal meio de transporte no período, monopólio da São Paulo Tramway Light and Power Co., demandando a implantação de uma infra-estrutura cara e que limitava a expansão urbana aos setores da cidade atingidos por esse serviço. As classes tendiam a viver relativamente próximas umas das outras, separadas pela moradia, ainda que a elite já apresentasse uma disposição de ocupar áreas próximas ao espigão da Paulista e os trabalhadores a irem viver nas áreas mais baixas próximas aos rios Tietê e Tamanduateí, onde também se instalavam as incipientes indústrias de São Paulo.

A alta densidade aliada às precárias condições de moradia e higiene levou à ocorrência de epidemias, tendo por foco as insalubres e precárias moradias operárias. As preocupações das elites com higiene e limpeza foram muitas vezes utilizadas como justificativa às reformas urbanas nas áreas centrais que visavam expulsar as populações pobres em intervenções de cunho haussmaniano.

A expressão embelezamento urbano sintetizou, no Brasil, o planejamento de origem renascentista que chegou através da França, e que vigorou por aqui até a década de 1940, sendo esta a proposta das classes dominantes para as cidades brasileiras até então. O termo embelezamento encobria estratégias como a erradicação da população trabalhadora da área central das cidades, objetivando mudanças de função desse centro para atender a interesses especulativos. A partir dos planos de embelezamento nasceu o planejamento urbano brasileiro lato sensu ${ }^{5}$.

As preocupações com a expansão da cidade, associadas à classificação e controle da população trabalhadora numa sociedade que se industrializava rapidamente, encobertas pela retórica da salubridade e saneamento, levaram ao aparecimento das primeiras legislações urbanísticas e edilícias. Segundo CALDIRA:

As elites temiam as epidemias como hoje temem o crime violento, e passaram a associar os pobres a doenças e epidemias, o que os levou a se afastar das

\footnotetext{
${ }^{4}$ Cf. CALDEIRA, Teresa Pires do Rio. Op. Cit., 2000, p. 213.

${ }^{5}$ Cf. VILLAÇA, Flávio. Uma contribuição à história do planejamento urbano no Brasil in DEAK, Csaba; SCHIFFER, Sueli Ramos, (Orgs.) O processo de urbanização no Brasil. São Paulo: EDUSP, 1999, p. 192-3.
} 
densamente povoadas áreas centrais em direção a áreas e empreendimentos exclusivos ${ }^{6}$.

A cidade precisava se expandir, abrindo espaço para os novos setores e atores da produção capitalista: as indústrias, o proletariado e a nova burguesia. As possibilidades de expansão da cidade eram: a Leste, a várzea alagável do Tamanduateí e a linha do trem; a norte, os terrenos estreitos da Luz, cortados pela linha do trem e o Tamanduateí; ao sul, os terrenos amplos e sem obstáculos da Liberdade e, a oeste, cruzando o vale do Anhangabaú, uma série de colinas levemente onduladas. Nesse momento se deu inicio ao processo de deslocamento das classes produzindo e consumindo o espaço urbano: os grupos de mais alta renda promovem uma decisiva ruptura com o tecido urbano histórico ao cruzar o vale do Anhangabaú, instalando-se na colina que viria a se constituir no chamado Centro Novo, hoje distrito da República. Daí seguiram se deslocando em sentido a sudoeste e oeste, nos novos bairros de elite dos Campos Elíseos e Higienópolis, até atingir a cumeeira da Paulista, de onde desceram às várzeas do rio Pinheiros por meio dos empreendimentos da Companhia City influenciados pelas cidades-jardim inglesas: Jardim Europa, Jardim América, entre outros. As classes trabalhadoras deram início a um deslocamento que se tornaria predominante nas suas localizações no espaço urbano da cidade, vindo a ocupar as várzeas alagáveis do Tamanduateí e do Tietê, acompanhando as indústrias que se instalavam nos bairros do Brás, Moóca, Pari e Barra Funda?

Na década de 1910 foi definido um zoneamento para a cidade de São Paulo, que instituía quatro zonas: a central, a urbana, a suburbana e a rural. Os códigos sanitários e de obras, com parâmetros bastante restritivos, aplicavam-se somente às zonas central e urbana, abrindo as portas - e, verdadeiramente, induzindo - à ocupação das áreas mais distantes e sem infra-estrutura pelas populações de baixa renda. Com isso, dava-se início ao processo de constituição do espaço urbano que caracterizaria o padrão de segregação predominante no período seguinte ${ }^{8}$.

Com a concentração e centralização crescentes do capital, surgiu a necessidade de dotar a cidade da estrutura necessária à expansão do nascente capitalismo industrial. Passa-se assim da cidade bela para a cidade eficiente, do consumo para a produção, sempre com o interesse imobiliário fortemente presente. O Plano de Avenidas de Prestes Maia, elaborado durante a administração de Pires do Rio à frente da Prefeitura, em 1930,

\footnotetext{
${ }^{6}$ CALDEIRA, Teresa Pires do Rio. Op. Cit., 2000, p. 214-5.

${ }^{7}$ Cf. VILLAÇA, Flávio. Op. Cit., 2001, p. 194-6.

${ }^{8}$ Cf. ROLNIK, Raquel. A Cidade e a Lei: legislação, política urbana e territórios na cidade de São Paulo. São Paulo: Nobel: Fapesp, 2003, p. 50.
} 
representa uma transição entre os antigos planos de melhoramentos e embelezamento urbanos e a necessidade de dotar a metrópole de uma estrutura racional e funcional às necessidades da indústria, equacionando os problemas relacionados aos deslocamentos intra-urbanos ${ }^{9}$.

Entre 1940 e 1980 formou-se e consolidou-se a vasta periferia da cidade de São Paulo, estendendo-se sobre diversos municípios vizinhos do conjunto de sua Região Metropolitana, decorrência de um formidável crescimento e urbanização experimentados ao longo do período, sustentado num modelo estruturado no tripé loteamento clandestino/autoconstrução/transporte sobre rodas.

Nesse período se estabeleceu e se consolidou o padrão centro-periferia de segregação que caracteriza as metrópoles brasileiras, de modo geral, São Paulo, em particular. Esse padrão caracteriza-se, em primeiro lugar, pela ocupação dispersa no território, diferentemente do padrão anterior; quando a cidade de São Paulo passou de uma densidade de 110 hab/ha em 1914 para 53 hab/ha em $1963^{10}$.

A segunda característica marcante desse padrão refere-se à separação das classes sociais no território, definida por espaços urbanos socialmente homogêneos. Radicaliza-se o processo iniciado com as primeiras leis de zoneamento de São Paulo, da década de 1910, que induziam à implantação de loteamentos precários, sem infraestrutura, destinados às classes trabalhadoras que não viam mais possibilidade de seguir residindo na cidade formal devido ao alto custo da terra urbanizada e legalizada.

A política habitacional estatal trazia em seu bojo uma política para o solo, seja pela intervenção, seja pela não-intervenção. Como bem observa MARICATO

O fato de o Estado fazer 'vistas grossas' à ocupação irregular de terra urbana através de invasões, grilagens, ou loteamentos clandestinos é uma forma de oferecer uma válvula de escape para as necessidades objetivas e concretas que a massa de trabalhadores urbanos, muitos dos quais recém-chegados do campo, tem de habitação. É uma forma ainda de viabilizar o corte entre a provisão capitalista de habitações e a não-capitalista, assegurando para a primeira os recursos financeiros disponíveis ${ }^{11}$.

Esse processo está íntima e diretamente relacionado à terceira característica definidora da urbanização brasileira e paulista no período, que diz respeito à predominância, nesse novo momento, da casa própria no atendimento às demandas habitacionais de todas as classes sociais. A diferença se dava na forma como se efetivava

\footnotetext{
${ }^{9}$ Cf. VILLAÇA, Flávio. Op. Cit., 1999, p. 199-208.

${ }^{10}$ Cf. CALDEIRA, Teresa Pires do Rio. Op. Cit., 2000, p. 218.

${ }^{11}$ MARICATO, Ermínia. Op. Cit., 1984, p. 110.
} 
esse atendimento: as camadas de alta e média rendas tiveram suas demandas supridas pelo mercado imobiliário capitalista, tendo garantido o acesso ao financiamento público habitacional, especialmente após a constituição do BNH; já as classes trabalhadoras viramse obrigadas a solucionar seu problema de moradia por meio da autoconstrução, em lotes muitas vezes clandestinos ou irregulares, pouco ou nada atendidos por infra-estrutura e bastante distantes do centro da cidade.

O quarto ponto refere-se à alteração no modelo de transporte e circulação na cidade, que se modifica com o abandono do bonde e a predominância do transporte sobre rodas, por meio dos ônibus e automóveis, possibilitados pela abertura de novas e modernas avenidas a partir da década de 1930. Se em 1948, entre todos os deslocamentos realizados em transporte coletivo na cidade de São Paulo, 4,2\% dos deslocamentos eram realizados por meio ferroviário, 52,2\% por bondes e 43,6\% por ônibus, em 1966 essa proporção se altera para pouco mais de 6\% dos deslocamentos realizados por trem, 2,4\% por bondes e 91,2\% por meio de ônibus ${ }^{12}$. Com a perda de relevância dos bondes, ganham importância no transporte público os ônibus, que tinham maior flexibilidade e não demandavam uma infra-estrutura cara e complexa como aquele, permitindo acessar os distantes bairros populares periféricos, com suas precárias ruas não pavimentadas. Os deslocamentos e a circulação na cidade passariam a ser resolvidos por meio de ônibus, pelas camadas populares, e por meio de automóveis, pelas classes altas e médias.

Nesse período a cidade e a metrópole assumem definitivamente a forma urbana descrita por VILLAÇA sob a configuração de setores de círculo onde se localizam e em cujas direções se deslocam as classes sociais no processo de produção e consumo do espaço urbano: os estratos de rendas média e alta mantendo, predominantemente, os setores a sudoeste do centro, enquanto as camadas populares vão ocupar, principalmente, o vetor leste da metrópole.

Às elites a segregação seria necessária, uma vez que o Estado não teria condições de produzir uma cidade burguesa moderna dispersa pelo território. Por isso as camadas de rendas altas e médias se concentrariam em um setor com a melhor localização relativa aos equipamentos do Estado, aos comércios e serviços, entre outros, onde ela tenha condições de concentrar a infra-estrutura, em especial a relacionada a seu meio predominante de transporte, o automóvel.

\footnotetext{
${ }^{12}$ Cf. VELZE, R., apud KOWARICK, L. e BONDUKI, N. Espaço Urbano e Espaço Político: do populismo à redemocratização. in KOWARICK, L. (Org.). As Lutas Sociais e a Cidade. Rio de Janeiro: Paz e Terra, 1994, p. 135 apud CALDEIRA, Teresa Pires do Rio. Op. Cit., 2000, p. 219.
} 
De modo perspicaz CALDEIRA observa que ainda que estivesse em curso um processo de radical apartação e segregação no espaço da cidade, com as classes trabalhadoras sendo relegadas a espaços precários, distantes e mal-equipados, nesse período não se verificaram grandes movimentos contestatórios ou reivindicatórios ${ }^{13}$, fato que teria levado alguns estudiosos da questão urbana a identificar a ocorrência de uma relativa "paz social". Isto seria, na verdade, decorrência direta da própria condição de segregação espacial, que ao estabelecer uma efetiva separação entre as classes reduziu as possibilidades de encontros e contatos, logo, de conflitos. Ainda nesse período verificouse um intenso crescimento econômico, que tendeu a aliviar as tensões sociais com a promessa da mobilidade social, induzindo à crença de que a condição de exclusão seria provisória, além do contexto repressivo às demandas populares representado pelo regime autoritário instaurado no país em $1964^{14}$.

Ao final desse período, com o esgotamento do modelo de expansão urbana vigente até então, decorrência, por um lado, da promulgação da Lei Federal 6766/79, que possibilitou a responsabilização judicial dos loteadores clandestinos e irregulares, assim como a crise econômica que se abateu sobre o Brasil a partir dos anos 1980, encerrando a ilusão da mobilidade social, a cidade de São Paulo deixou de oferecer "a possibilidade de ignorar as diferenças de classe; antes de mais nada, é uma cidade de muros com uma população obcecada por segurança e discriminação social"15. O padrão de segregação que passa a vigorar na produção dos novos espaços urbanos, sobrepondo-se ao padrão anterior centro-periferia, é aquele que CALDEIRA vai chamar de "enclaves fortificados", em que as classes sociais de alta e baixa rendas passam a compartilhar alguma proximidade de localização no espaço intra-urbano da cidade, ainda que esta proximidade física não represente contato entre as mesmas.

Nesse período se consolidou tendência que já se anunciava na década de 1970: segundo dados do Censo 2000 do IBGE, entre os anos de 1991 e 2000 houve perda de população em 53 dos 96 distritos da cidade de São Paulo - além do município de São Caetano do Sul -, justamente as áreas mais consolidadas e com melhor infra-estrutura do município. Em contrapartida, as periferias da capital e alguns municípios da Grande São

\footnotetext{
${ }^{13}$ Isto só acontecerá no final da periodização estabelecida por ela, com o surgimento dos movimentos sociais urbanos na periferia de São Paulo no final da década de 1970, reivindicando exatamente melhorias nas condições urbanas dos bairros populares, demandando principalmente melhorias no transporte e a implantação de equipamentos públicos, especialmente de educação e saúde. Surpreendentemente e de forma não prevista, esse movimento contestatório surgiu não no ambiente do trabalho, mas no ambiente do viver, do não-trabalho.

${ }^{14}$ Cf. CALDEIRA, Teresa Pires do Rio. Op. Cit., 2000, p. 221.

${ }^{15}$ CALDEIRA, Teresa Pires do Rio. Op. Cit., 2000, p. 231.
} 
Paulo assistiram a um intenso crescimento, com resultados trágicos nas áreas de proteção aos mananciais nas bacias das represas Billings e Guarapiranga ${ }^{16}$.

\section{Taxa de crescimento anual da população \\ Região Metropolitana e Distritos do Município de São Paulo - 1991/2005}

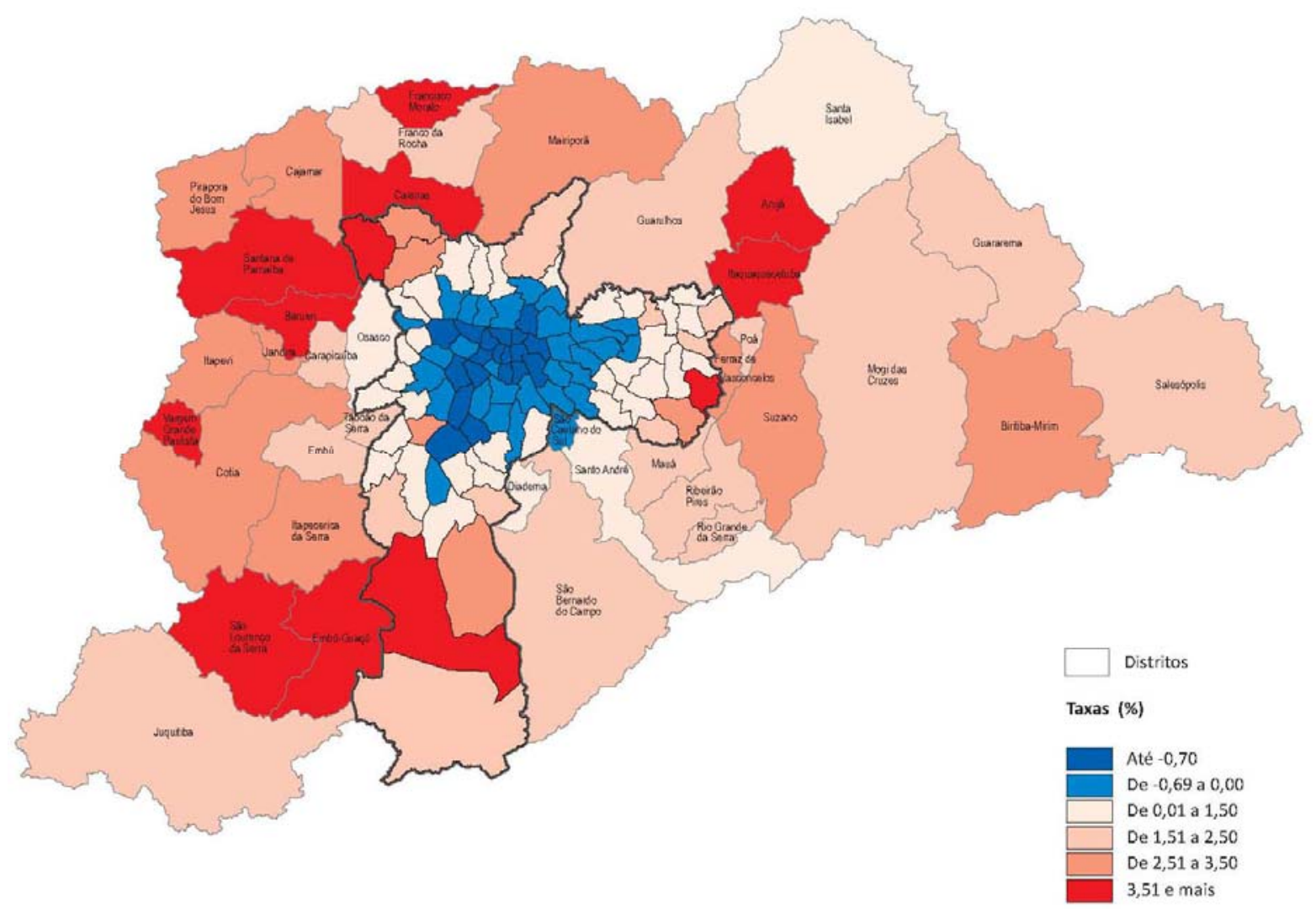

Fonte: SÂO PAULO (cidade). Secretaria Municipal de Planejamento - SEMPLA. Departamento de Estatística e Produção da Informação - DIPRO. Olhar São Paulo - contrastes urbanos. São Paulo: SEMPLA, 2007, p. 14 - IBGE - Censos Demográficos 1991, 2000; SEMPLA/DIPRO - estimativa populacional para 2005.

Entre 1980 e 1991 sete distritos haviam apresentado taxas de crescimento demográfico acima de 5\% ao ano: na Zona Sul, Vila Andrade e Parelheiros, este último no extremo sul da cidade; na Zona Norte, Anhanguera e Jaraguá; e no extremo da Zona Leste, os distritos de Iguatemi, José Bonifácio e Cidade Tiradentes, os dois últimos com incríveis taxas de crescimento populacional anual de 14,21 e 24,55\%, respectivamente, decorrência direta da produção de grandes conjuntos habitacionais públicos, especialmente neste último, onde está localizado o maior conjunto habitacional de São Paulo e o último grande empreendimento financiado pelo BNH antes de sua extinção.

Entre 1991 e 2000 os distritos que apresentaram maior crescimento populacional, na faixa superior a $5 \%$ ao ano, também foram sete e aqueles localizados na franja da área

\footnotetext{
${ }^{16}$ Para um exame detalhado da situação contemporânea nas áreas de manancial ver MARTINS, Maria Lúcia Refinetti. Moradia e Mananciais: Tensão e diálogo na metrópole. São Paulo: FAUUSP/FAPESP, 2006.
} 
urbanizada, como Jaraguá e Anhanguera, no extremo norte da área urbanizada, este último o distrito que mais cresceu no período, $13,38 \%$ ao ano, principalmente devido à expansão de loteamentos clandestinos; Vila Andrade, Parelheiros e Grajaú, na Zona Sul; e Iguatemi e Cidade Tiradentes, este último com um crescimento ainda muito significativo de $7,89 \%$ ao ano ${ }^{17}$.

\section{Taxa de crescimento anual da população} Município de São Paulo - 1991/2005
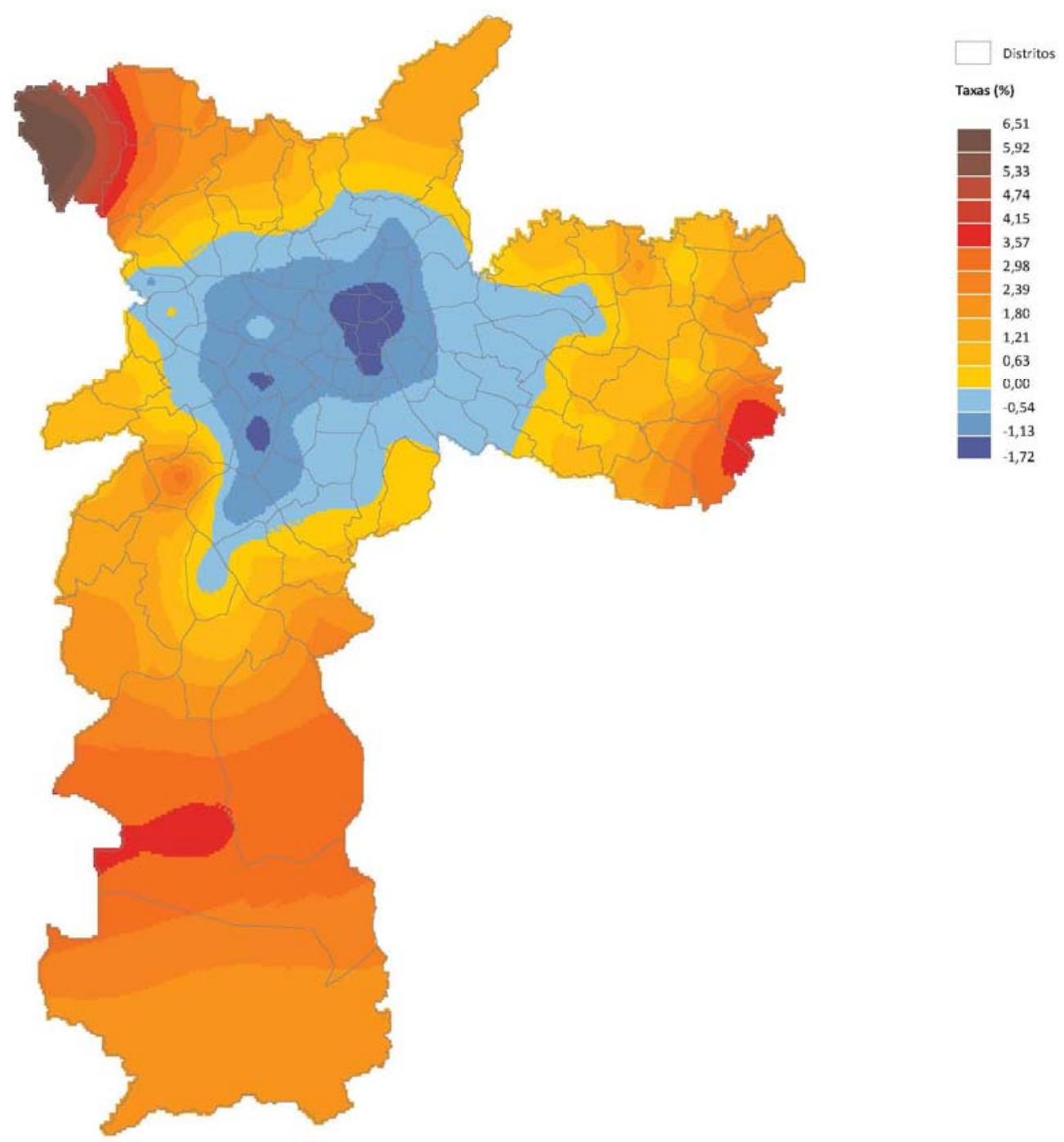

Fonte: SÂO PAULO (cidade). Secretaria Municipal de Planejamento - SEMPLA. Departamento de Estatística e Produção da Informação - DIPRO. Olhar São Paulo - contrastes urbanos. São Paulo: SEMPLA, 2007, p. 15 - IBGE - Censos Demográficos 1991, 2000; SEMPLA/DIPRO - estimativa populacional para 2005.

${ }^{17}$ IBGE - Censos demográficos 1980/1991/2000, Contagem da População 1996, in: SEMPLA/DIPRO Secretaria Municipal de Planejamento/Departamento de Estatística e Produção de Informação Prefeitura do Município de São Paulo. Município em Dados. Acessado do sítio "http://www9.prefeitura.sp.gov.br/sempla/md/" em 27 de fevereiro de 2008. 
Esses distritos, de modo geral, apresentam uma ocupação majoritária de populações de baixa renda, exceção que pode ser feita apenas a Vila Andrade, não por acaso o único distrito situado no vetor de localização das classes altas e médias na cidade, a região sudoeste. Paralelamente, houve um grande incremento populacional em municípios da Região Metropolitana, como Santana de Parnaíba e Barueri, que viram proliferar condomínios e loteamentos fechados exclusivos aos estratos de rendas altas e médias.

Sobrepondo-se ao centro-periferia - que segue em vigor e se reproduzindo continuamente - o novo padrão de segregação caracterizado pelos chamados "enclaves fortificados" (condomínios fechados, shopping centers, centros empresariais e de serviços etc) gera uma cidade mais diversificada e, sobretudo, mais complexa que no período anterior. CALDEIRA reputa a instalação desse novo processo a uma combinação de inúmeros fatores: 1) a reversão do crescimento demográfico, com a redução do ritmo de crescimento populacional na cidade de São Paulo e na Região Metropolitana como um todo; 2) recessão econômica, desindustrialização e expansão do setor terciário; 3) melhoria das condições de moradia e urbanidade da periferia combinada a um empobrecimento geral das classes trabalhadoras, decorrência do fator anterior; 4) abandono das áreas centrais por parte das elites; e 5) ampla difusão do medo do crime violento.

O terceiro ponto levantado por Caldeira, relacionado às melhorias habitacionais e urbanas por que passou e passa a periferia paulistana, nos interessa aqui no sentido que MARQUES $^{18}$ identifica como um dos instrumentos na redução da desigualdade socioespacial que impera na Região Metropolitana de São Paulo e no Brasil, por meio da implementação de políticas públicas de implantação de infra-estrutura urbana.

Escrito num contexto de crise econômica no Brasil, o texto de CALDEIRA associa como partes de uma mesma conjuntura a melhoria urbanística e o empobrecimento dessas camadas populares. Difícil precisar se o aquecimento econômico e a ampliação do emprego formal vividos até o ano de 2008, vinculados à expansão das políticas de distribuição de renda implicam, de alguma forma e em que grau, na melhoria da condição de vida na periferia da Grande São Paulo, visto que ainda não existem dados consistentes que permitam responder a essa questão.

O enfrentamento da segregação e das desigualdades socioespaciais em São Paulo requer uma ampla compreensão desses fenômenos e suas características particulares, para a constituição de políticas públicas, tanto universais quanto focadas,

${ }^{18}$ MARQUES, Eduardo. Op. Cit., 2005a. 
objetivando melhorias no acesso aos equipamentos, serviços e amenidades urbanas aos mais diferentes grupos sociais. A atual caracterização da Região Metropolitana de São Paulo é muito mais complexa e exige uma análise mais sofisticada que o simples enquadramento a modelos territoriais de localização socioespacial. O modelo centroperiferia, apesar de dar conta do fenômeno em relação às suas tendências gerais, não é suficiente para o estabelecimento dessa leitura com vistas à formulação de políticas específicas de combate à segregação. As condições habitacionais, urbanas e ambientais nos grandes conjuntos da COHAB-SP (ou da CDHU) necessitam ações distintas dos polígonos de favelas, ou dos loteamentos irregulares/clandestinos que avançam sobre as franjas externas da cidade. O espaço metropolitano demanda uma abordagem não homogeneizadora das condições de vida de sua população ${ }^{19}$.

\subsection{A promoção habitacional pública na produção do espaço urbano metropolitano}

Até meados da década de 1990 a política de enfrentamento da carência habitacional consistiu, quase exclusivamente, na produção de novas unidades. Essa produção assumiu diversas características que implicaram diretamente na qualidade de vida das populações moradoras desses conjuntos, e que resultaram na reafirmação e consolidação de determinados padrões de segregação da cidade e da sociedade paulistana, reforçando e reproduzindo as desigualdades socioespaciais características da Região Metropolitana de São Paulo e sendo determinantes na qualidade da vida de todos os seus moradores.

LEDRUT, ao estudar os grandes conjuntos habitacionais de Toulouse na década de 1960 concluiu que as decisões projetuais e construtivas impactavam muito mais a qualidade de vida que propriamente a escala dos conjuntos. Em grande medida, a promiscuidade social e a falta de privacidade na unidade, especialmente aquela relacionada à sensação de ouvir e ser ouvido, de observar e ser observado pelos vizinhos representariam os determinantes fundamentais em relação à identificação de baixa qualidade, sem uma relação mais direta com a densidade ou tamanho dos mesmos ${ }^{20}$. Dessa forma, esse autor conclui que

\footnotetext{
${ }^{19}$ Estudo recente de MARQUES analisa a grande heterogeneidade das dinâmicas espaciais, econômicas e sociais na metrópole, demandando respostas específicas às diferentes periferias, em lugar de uma periferia única e homogênea como é costumeiramente tratada na literatura. Cf. MARQUES, Eduardo. Espaço e Grupos Sociais na Virada do Século XXI in MARQUES, Eduardo e TORRES, Haroldo (Org.). São Paulo: segregação, pobreza e desigualdades sociais. São Paulo: SENAC, 2005b, p. 70-6.

${ }^{20}$ LEDRUT, Raymond. Espacio social de la ciudad: problemas de sociología aplicada al ordenamiento urbano. Buenos Aires: Amorrortu, 1974, p. 86. Ledrut estudou nove grandes conjuntos, construídos na periferia de Toulouse entre 1948 e 1961. Sua pesquisa procurava identificar quais os fatores
} 
a respeito da independência pessoal e familiar, não é a reunião nos grandes edifícios ou a concentração em conjuntos habitacionais muito densos o que exerce o efeito mais desfavorável, e sim a falta de isolamento da moradia, dentro do edifício e do conjunto. ${ }^{21}$

No caso tolosano tem pouca relevância a questão da segregação socioespacial em função da localização, visto que nenhum daqueles conjuntos estudados por LEDRUT dista mais que quatro quilômetros do centro daquela cidade. Apesar desse fator, que impede um paralelo mais imediato entre seu estudo de caso e a realidade metropolitana aqui analisada, suas conclusões sobre o impacto que as decisões tomadas acerca do projeto e construção das unidades habitacionais têm sobre a vida dos moradores dos grandes conjuntos nos interessam bastante, na medida em que condicionam a vida cotidiana dessa população. Outra consideração interessante de LEDRUT diz respeito à sua constatação de que os conjuntos com os piores "climas sociais" correspondiam àqueles que apresentavam as populações residentes mais homogêneas socialmente. Aliado a isso, ele também identifica a desigualdade de acesso aos serviços urbanos ali verificada em relação à cidade histórica, uma vez que nos conjuntos construídos a essa época a legislação que regulava os $\mathrm{HLM}^{22}$ impedia a edificação para usos não-residenciais, resultando em grandes áreas monofuncionais ${ }^{23}$.

Para LEDRUT as características que determinavam, em última instância, a qualidade ambiental de um conjunto habitacional dizem menos respeito ao seu tamanho ou densidade, tendo muito mais importância as definições econômicas e as decorrentes da legislação urbanística, assim como as decisões projetuais que impactam diretamente no ambiente edificado.

No caso paulistano precisamos ponderar as conclusões de LEDRUT em seu estudo de uma cidade média do interior francês como Toulouse, que hoje tem pouco mais de 400.000 residentes, sede de uma região metropolitana com cerca de um milhão de habitantes. Essas conclusões, contudo, levantam questões coerentes com os problemas enfrentados pelas populações residentes nos conjuntos habitacionais da COHAB na Região Metropolitana de São Paulo, onde estes espaços concentram uma quantidade de carências e deficiências tais que impedem que se responsabilize apenas sua escala e densidade pela baixa qualidade ambiental que apresentam.

preponderantes e quais os principais condicionantes que implicam na qualidade de vida de seus moradores.

${ }^{21}$ LEDRUT, Raymond. Op. Cit., 1974, p. 86. Itálico no original

${ }^{22}$ Habitation à loyer modéré. Moradia de aluguéis moderados, numa tradução livre.

${ }^{23}$ Cf. LEDRUT, Raymond. Op. Cit., 1974, p. 113. 
As decisões tomadas no âmbito da política habitacional nacional e pela COHAB$\mathrm{SP}$, de modo particular, tiveram impacto sob diversas formas, implicando de variados modos na reprodução das condições de segregação das populações objeto dessas políticas. As desigualdades socioespaciais entre os diferentes setores da cidade, especificamente em relação aos conjuntos habitacionais, são determinadas por fatores distintos que se influenciam e se condicionam dialeticamente, num processo multidimensional.

Cada uma das variadas maneiras como a produção do espaço impactou na segregação desses contingentes populacionais, integrando-os subalternamente à cidade, é fruto das características assumidas por essa promoção. Essas variadas dimensões da produção da segregação e das desigualdades no espaço urbano podem ser identificadas a partir das características que estruturam os programas habitacionais: os aspectos econômico-financeiros dos programas, as políticas públicas urbanas e as decisões projetuais assumidas quando da implantação dos conjuntos.

Todos estes fatores estão inter-relacionados e influenciam-se dinamicamente. As decisões econômico-financeiras estão relacionadas às condições de financiamento, na definição dos grupos sociais solváveis e dos estratos de renda atendidos, na visão empresarial inerente a essa política, assim como na lógica que levou à definição das localizações desses empreendimentos habitacionais, decidida em função dos custos da terra. Por outro lado, esse custo decorre da dinâmica intra-urbana da metrópole, com seus diferenciais de acessibilidade e infra-estrutura, equipamentos e serviços implantados e disponíveis. Assim, a escolha de áreas para implantação de conjuntos habitacionais com baixo custo da terra, mas com grandes diferenciais de infra-estrutura demandava, para se viabilizar socialmente, amplos investimentos em equipamentos e infra-estrutura. A esses fatores somam-se aqueles decorrentes das decisões projetuais tomadas e que resultaram nas características morfológicas assumidas pelos bairros conformados por esses conjuntos, redutores da vida urbana, e tipológicas, onde predominou a utilização de projetos-padrão, inadequados tanto com relação às necessidades individuais de seus habitantes quanto na sua implantação e relação com o sítio.

Afora esses aspectos mais palpáveis relativos às carências e condicionantes físicos desses territórios, faz-se necessário ressaltar a baixa qualidade dos grandes conjuntos implantados a esse tempo no que se refere às características de uso e apropriação dessas vastas áreas monofuncionais, rígidas, dificultando sua adaptação e transformação às necessidades de seus moradores, que se faziam mais complexas que o projetado e construído pela COHAB-SP. 
Os grandes conjuntos habitacionais, para além de sua lógica segregadora, são instrumentos reprodutores das desigualdades socioespaciais, acabando por se constituir em elemento ativo na alienação e deterioração da vida urbanas das populações que aí residem, implicando na própria perda da experiência da cidade. Essa perda da cidade não está

necessariamente atrelada à pobreza material, à pobreza absoluta, na figura da ausência de serviços e equipamentos urbanos. Aparece, em última instância, como perda da fluidez da vida urbana, como perda da vida urbana propriamente, e de suas possibilidades. A deterioração da vida urbana não seria fundamentalmente função do crescimento da cidade, identificado ao crescimento de problemas e carências materiais estritos. ${ }^{24}$

A desvinculação entre a promoção habitacional massiva e uma política de desenvolvimento urbano resultou numa produção fragmentadora da cidade, redutora da vida urbana que poderia se desenvolver nesses espaços. Nos grandes conjuntos a experiência humana do "habitar" ficou reduzida ao espaço projetado do conjunto habitacional, restringindo o "'ser humano' a alguns atos elementares: comer, dormir, reproduzir-se" 25 , não prevendo e não possibilitando a apropriação de forma a atender às necessidades da população ali instalada além da sua sobrevivência imediata, impossibilitando a realização daquilo que Henri Lefebvre denominava de "direito à cidade".

Como primeiro elemento definidor das características da produção da COHAB e com impacto direto na delimitação desses territórios segregados assim como no reforço às desigualdades socioespaciais, podemos identificar a sua própria vinculação às políticas definidas no âmbito do $\mathrm{BNH}$, em que a constituição de uma política pública nacional de habitação prescindiu de uma política de desenvolvimento urbano. O significativo montante de recursos disponibilizado pelo SFH foi muito mais importante na consolidação de um mercado imobiliário capitalista restrito às camadas de alta e média rendas que no atendimento às demandas por habitação das classes populares ou na implantação em larga escala de infra-estrutura urbana ${ }^{26}$.

A lógica empresarial do SFH, objetivando o retorno financeiro dos recursos investidos, excluía aquelas populações que não representassem uma demanda solvável aos seus empréstimos, o que, num contexto de achatamento salarial e repressão à

\footnotetext{
${ }^{24}$ DAMIANI, Amélia Luisa. Op. Cit., 1993, p. 14.

${ }^{25}$ LEFEBVRE, Henri. Op. Cit., 1999, p. 80.

${ }^{26}$ Importante ressaltar que o BNH mobilizou uma grande quantidade de recursos para a implantação de infra-estrutura urbana, sobretudo no período 1970-1976, Cf. MARICATO, Ermínia. Op. Cit, 1987. Contudo, estes investimentos foram concentrados, principalmente, nas regiões ocupadas pelas camadas de alta e média rendas nas cidades brasileiras, não atingindo justamente as áreas de maior precariedade urbana.
} 
organização política, como durante a vigência do modelo SFH/BNH, manteve à margem das políticas habitacionais grandes contingentes populacionais ${ }^{27}$. Àquelas camadas pobres imediatamente acima da demanda miserável não solvável restaram os conjuntos da COHAB na periferia metropolitana. Esse tipo de produção impactou negativamente na segregação desses grupos e na sua própria inserção social com cidadania plena.

A política habitacional sob a regência do BNH quase que invariavelmente resultou na produção de espaços altamente segregados e excludentes, definindo territórios ocupados de acordo com a capacidade de pagamento dos mutuários, reflexo direto das relações entre as classes sociais sobre o território. NAKANO bem observa que 0 condicionamento dos programas habitacionais à faixa de renda acabava por promover a compartimentalização dos "grupos sociais nos territórios de moradias produzidas por tais programas. De certo modo, o Estado opera na distribuição territorial da população segmentando o espaço urbano ou segregando grupos sociais." ${ }^{28}$

Assim, a tipologia do conjunto habitacional em si representava um distintivo de classe, identificando seus moradores de acordo com seu poder aquisitivo, com seu status na hierarquia do poder e do dinheiro ${ }^{29}$. A identificação da classe social com o território por ela ocupado na cidade resultaria em uma valoração que se estabelece dialeticamente sobre o espaço urbano e seus moradores: ao passo que os territórios onde se encontram implantados os condomínios de alta e média rendas receberiam uma valoração positiva tanto o espaço quanto seus moradores - no caso dos conjuntos habitacionais, assim como nas favelas e outros espaços ocupados e apropriados pela classe trabalhadora, ocorreria uma "valoração negativa, estigmatizante"30.

\footnotetext{
${ }^{27} \mathrm{Na}$ verdade essa lógica privilegiou o investimento dos recursos do banco em setores mais rentáveis, o que explica a inflexão na orientação ao investimento em grandes obras de infra-estrutura, do saneamento urbano à construção de usinas hidrelétricas, onde o retorno era maior e o risco de inadimplência nulo. Além disso, essa reorientação atenderia aos interesses da indústria da construção pesada, que dificilmente se envolve com a construção civil habitacional, sobretudo para baixa renda. Cf. MARICATO, Ermínia. Op. Cit., 1987, p. 40.

${ }^{28}$ NAKANO, A. K. Op. Cit., 2002, p. 107.

${ }^{29} \mathrm{O}$ BNH estabeleceu inicialmente um teto de financiamento para o chamado mercado popular, que pretendia atingir famílias com rendimento de um até três Salários Mínimos, limite estendido posteriormente para um máximo de cinco Salários Mínimos, cujos agentes seriam as COHABs. Cf. AZEVEDO, Sérgio e ANDRADE, Luís Aureliano Gama de. Op. Cit., 1982, p. 65. Evidentemente é preciso considerar que, neste caso, as rendas dos demais membros da família, como cônjuges e filhos, que contribuem significativamente na composição da renda familiar, eram facilmente escamoteadas a fim de permitir o enquadramento nas faixas de acesso aos financiamentos, fraudando o processo de seleção da demanda e, possivelmente, elevando a renda média dessas populações moradoras. Entretanto, é forçoso considerar que o estabelecimento dos territórios representados pelos conjuntos habitacionais da $\mathrm{COHAB}$, ao estabelecerem os critérios de definição de demanda a partir da renda, acabam por produzir um espaço, relativamente, socialmente homogêneo.
}

${ }^{30}$ NAKANO, A. K. Op. Cit., 2002, p. 133. 
O estabelecimento de espaços socialmente homogêneos representados pelos conjuntos da COHAB é reflexo do condicionamento imposto pelos programas de financiamento do $\mathrm{BNH}$, que acabavam por obstaculizar tentativas de produzir conjuntos com algum grau de heterogeneidade interna, possível a partir da oferta de unidades habitacionais para variados estratos de renda. DAMIANI relata, a partir de depoimento do ex-diretor de planejamento da COHAB-SP Henri Cherkezian, que a própria estrutura montada pelo $\mathrm{BNH}$, que definia carteiras de financiamento distintas e estanques para diferentes demandas de renda, impedia essa mescla de grupos sociais. Cada carteira de crédito do BNH exigia, para a concessão do financiamento, que o terreno todo onde seria implantado o conjunto fosse dado como garantia. Dessa forma, era impossível dar a mesma garantia ao banco para a obtenção de crédito para outra faixa de renda, impedindo, por meio de uma política pública nacional, a heterogeneidade social nesses espaços ${ }^{31}$.

Um segundo elemento determinante na promoção habitacional pública no tocante à segregação diz respeito à localização dos conjuntos, caracterizada pela busca por áreas em que o valor da terra fosse relativamente baixo, permitindo sua diluição no custo final da unidade habitacional. Este fator orientou a política de aquisição de terras localizadas nas franjas metropolitanas. Dessa forma, o impacto dos custos da terra ficava atenuado, chegando a representar apenas $5 \%$ do valor final da unidade habitacional, menos que os valores despendidos nos serviços de terraplenagem (7\%) ficando o grosso do recurso destinado à construção do edifício $(73 \% \text { do total })^{32}$. No caso das cooperativas, que também operavam com recursos do BNH, caso dos INOCOOPs, no período 1981-1982 o custo do terreno correspondia a cerca de $6,07 \%$ do total do valor da unidade; a construção representava $69,03 \%$ desse custo, a infra-estrutura $7,39 \%$ e equipamentos e projeto $1,56 \%{ }^{33}$. Ressalte-se que nesse cálculo sobre o valor dos terrenos não se considerou o custo de se levar a "cidade" até os conjuntos.

A aquisição de áreas para a edificação de conjuntos habitacionais por parte das COHABs se deu de diversas formas: por meio de doações de terrenos, tanto por entes governamentais das diferentes esferas quanto de agentes privados; pelo repasse de áreas pelo $\mathrm{BNH}$, oriundas do patrimônio dos Institutos de Previdência, da Fundação da Casa Popular, do patrimônio da União ou recebidas pelo banco como pagamento de dívidas;

${ }^{31}$ Cf. DAMIANI, Amélia Luisa. Op. Cit., 1993, p. 91-3.

32 Cf. MARICATO, Ermínia. Op. Cit., 1987, p. 53. Esses valores correspondem à estrutura de custos médios de um apartamento de $50 \mathrm{~m}^{2}$ produzido pela COHAB-SP para o ano de 1983.

${ }^{33}$ Cf. Relatório BNH/DETER - Departamento de Terras, 1985, p. 57 apud SILVA, Helena Menna Barreto. Op. Cit., 2000, Nota 1. É importante salientar que o custo discriminado como "infra-estrutura", nesse caso, refere-se àquela implantada nos condomínios, não incidindo aqui o custo de implantação da infraestrutura urbana e sua conexão com as redes existentes, como veremos mais adiante. 
pela aquisição ligada ao financiamento dos conjuntos habitacionais; ou através do financiamento vinculado à formação de estoque de terras.

Para fazer frente à necessidade de aquisição de terrenos para a construção de grandes conjuntos, política que se coadunava com o recém-lançado PLANHAP - Plano Nacional de Habitação Popular, em fins dos anos 1970 o BNH criou seu DETER Departamento de Terras, com o objetivo de coordenar as ações para a formação de um estoque de terras das COHABs.

Segundo relatório do DETER de 1985 as vantagens na constituição desse estoque residiam na

possibilidade de comprar terrenos a baixo custo que serão beneficiados por futuros investimentos públicos em infra-estrutura e serviços urbanos; a elevação do poder de barganha do comprador, que vai ao mercado sem estar pressionado por uma necessidade imediata; e as possibilidades de o comprador examinar e negociar várias ofertas e não uma única, como no caso da compra com o projeto habitacional. ${ }^{34}$

A constituição do estoque de terras da COHAB-SP se deu, principalmente, com a aquisição de áreas rurais nas franjas da Zona Leste da cidade de São Paulo, muitas vezes com importantes restrições ambientais. Para viabilizar o empreendimento de conjuntos nesses locais se instituiu um privilégio ao poder público para a edificação de conjuntos de interesse social na Z8-100/1 - caso dos conjuntos do complexo Santa Etelvina e Barro Branco, no distrito de Cidade Tiradentes ${ }^{35}$.

O baixo custo dessas terras permitiu que os recursos fossem direcionados propriamente à construção. As citadas economias de escala que seriam possibilitadas pela construção dos grandes conjuntos não chegaram a alterar essa composição de custos. SILVA identifica uma funcionalidade nesse padrão de implantação de grandes conjuntos em áreas desurbanizadas, uma vez que propiciava grandes obras de infra-estrutura e terraplenagem, além de garantir uma fatia maior do recurso financiado para a construção das unidades em si. Dessa forma, seriam atendidos os interesses das empreiteiras e do

\footnotetext{
${ }^{34}$ Relatório BNH/DETER - Departamento de Terras, 1985, p. 31 apud SILVA, Helena Menna Barreto. Op. Cit., 2000, p. 52.

35 "A Lei no 9.300, de 24 de agosto de 1981, reorientou a ocupação da zona rural leste e oeste, propondo a sua divisão em cinco tipos (Z8-100/1, Z8-100/2, Z8-100/3, Z8-100/4 e Z8-100/5), com normas de uso e de ocupação do solo que introduzem uma transição entre o uso urbano e o rural. Esta lei alterou as características da zona de uso Z7, criando parâmetros urbanísticos para essa nova zona de predominância industrial, cuja localização na Zona Leste tem por objetivo propiciar o aumento da oferta de emprego junto ao grande número de habitação populares, na sua maior parte implantadas pela Cohab." Acessado do sítio da SEMPLA - Secretaria Municipal do Planejamento em 10 de abril de 2008 no endereço http://www.prodam.sp.gov.br/sempla/zone.htm.
} 
próprio $\mathrm{BNH}$, que era mais bem remunerado pelos empréstimos relacionados a obras de desenvolvimento urbano. Segundo ela

os empréstimos para infra-estrutura - saneamento básico, abertura de acessos viários, pavimentação - eram feitos às prefeituras com maiores taxas de juros, propiciando melhor retorno que a habitação popular e mesmo o equilíbrio da remuneração devida ao Fundo de Garantia por Tempo de Serviço (FGTS). Nos terrenos com condições geomorfológicas desfavoráveis ou com partidos de projeto inadequados, a execução de obras de terraplenagem - também não incidentes no financiamento ao mutuário - atende também à lógica de beneficiar as empresas construtoras. ${ }^{36}$

Corroborando sua tese, SILVA defende que "a comparação com valores de terrenos mais bem localizados permite concluir que o aproveitamento destes terrenos, com a densidade apropriada, teria resultado em custos similares ou menores"37. Por meio da COHAB-SP, o poder público produziu espaços distantes, apartados da cidade, sendo um agente ativo da expansão da mancha urbana, ao constituir vetores de expansão com a implantação de seus conjuntos habitacionais, isso num momento em que estudos apontam que cerca de $40 \%$ dos terrenos em Z2 - localizadas em áreas urbanizadas e adequadas à edificação multifamiliar - encontravam-se vazios ${ }^{38}$.

A produção dos grandes conjuntos pela COHAB-SP, especialmente na Zona Leste de São Paulo, foi possibilitada, de um lado, pela existência de grandes áreas remanescentes de antigas fazendas improdutivas, em áreas sem urbanização e, de outro, como já dito, pela orientação de se adquirir terrenos a baixo custo. Em reportagem de 1981, o jornal Folha de São Paulo apresentava os planos megalomaníacos da Companhia, na figura de seu presidente, o Engenheiro José Celestino Bourroul, para a constituição de uma nova cidade no extremo da Zona Leste, tendo por inspiração a capital federal, a ser projetada e executada pela COHAB, e que se esperava ver concluída no ano de 1985:

São Paulo, zona Leste, 1985: quando o futuro chegar e se todos os planos derem certo, o metrô e as grandes avenidas levarão a uma nova cidade de 1.685.000 habitantes, 337 mil novas moradias e 22.400 .000 metros quadrados. Esta é a projeção que faz hoje o entusiasmado engenheiro aposentado da Prefeitura José Celestino Bourroul, 58 anos, há seis anos presidente da Companhia Metropolitana de Habitação de São Paulo (Cohab), que joga todos os seus trunfos nas novas fronteiras da Zona Leste. ${ }^{39}$

\footnotetext{
${ }^{36}$ SILVA, Helena Menna Barreto. Op. Cit., 2000, p. 53.

37 SILVA, Helena Menna Barreto. Op. Cit., 2000, p. 53.

${ }^{38}$ Cf. SILVA, Helena Menna Barreto. Op. Cit., 2000, p. 55.

${ }^{39}$ Folha de São Paulo, 30 de junho de 1981, p. 10. O grifo é meu.
} 
No ano de 2009, os conjuntos em Itaquera, José Bonifácio, Guaianases e Cidade Tiradentes, entre outros, demonstram que esse futuro não chegou, que dizer do distante ano de 1985. Analisando-se o histórico da produção da Companhia, a execução de toda essa infra-estrutura é que representaria um desvio ao padrão representado pela política habitacional implementada pela COHAB-SP.

Inerente à lógica quantitativa da produção habitacional durante o período de existência do $\mathrm{BNH}$, que privilegiava a produção do maior número de unidades, no menor tempo e ao menor custo possível, construiu-se dezenas de milhares de unidades afastadas do centro, dos postos de trabalho, dos equipamentos de saúde, educação, cultura, dos comércios e serviços, enfim, de todo tipo de equipamento que lembrasse, ainda que vagamente, a cidade. Essa dinâmica de implantação periférica dos conjuntos produziu e reproduziu segregação, a saber:

baixa integração com a malha urbana existente, escassa infra-estrutura e enormes custos de transporte, com evidentes efeitos negativos sobre a segregação territorial urbana. De forma a baratear ainda mais a produção, foram realizados conjuntos de grandes proporções, agravando os problemas de isolamento social e induzindo à constituição de padrões de sociabilidade muito negativos. ${ }^{40}$

Sobretudo no período entre 1975 e 1985 - que, não por acaso, coincide com a inflexão do BNH em direção à habitação popular - a política de aquisição de terras para estoque pela COHAB-SP levou à compra de grandes áreas nas franjas ou totalmente desconectada da malha urbana da cidade, como vemos nos mapas a seguir.

A produção dos gigantescos espaços monofuncionais representados pelos grandes conjuntos habitacionais das décadas de 1970 e 1980 seria resultado da existência de grandes "vazios urbanos", de baixo custo, os quais, por outro lado, deveriam permitir uma economia de escala na implantação de milhares de unidades a uma só vez. DAMIANI defende que a produção desses grandes conjuntos fez parte de uma estratégia política de busca por legitimidade, num momento em que o regime era posto em cheque, visto que o milagre econômico fazia água ${ }^{41}$. A questão levantada pela autora é interessante para se compreender a lógica da promoção habitacional pública sob a forma de grandes conjuntos; contudo, ela não dá conta de explicar toda a reorientação empreendida pelo BNH com vistas às camadas de menor renda a partir do PLANHAP de 1973.

\footnotetext{
40 MARQUES, Eduardo e SARAIVA, Camila. As políticas de habitação social, a segregação e as desigualdades na cidade in MARQUES, Eduardo e TORRES, Haroldo (Org.). São Paulo: segregação, pobreza e desigualdades sociais. São Paulo: SENAC, 2005, p. 270.

${ }^{41}$ Cf. DAMIANI, Amélia Luisa. Op. Cit., 1993, p. 104.
} 
São Paulo: área urbanizada 1963-1974

Terrenos adquiridos pela COHAB-SP entre 1966 e 1974

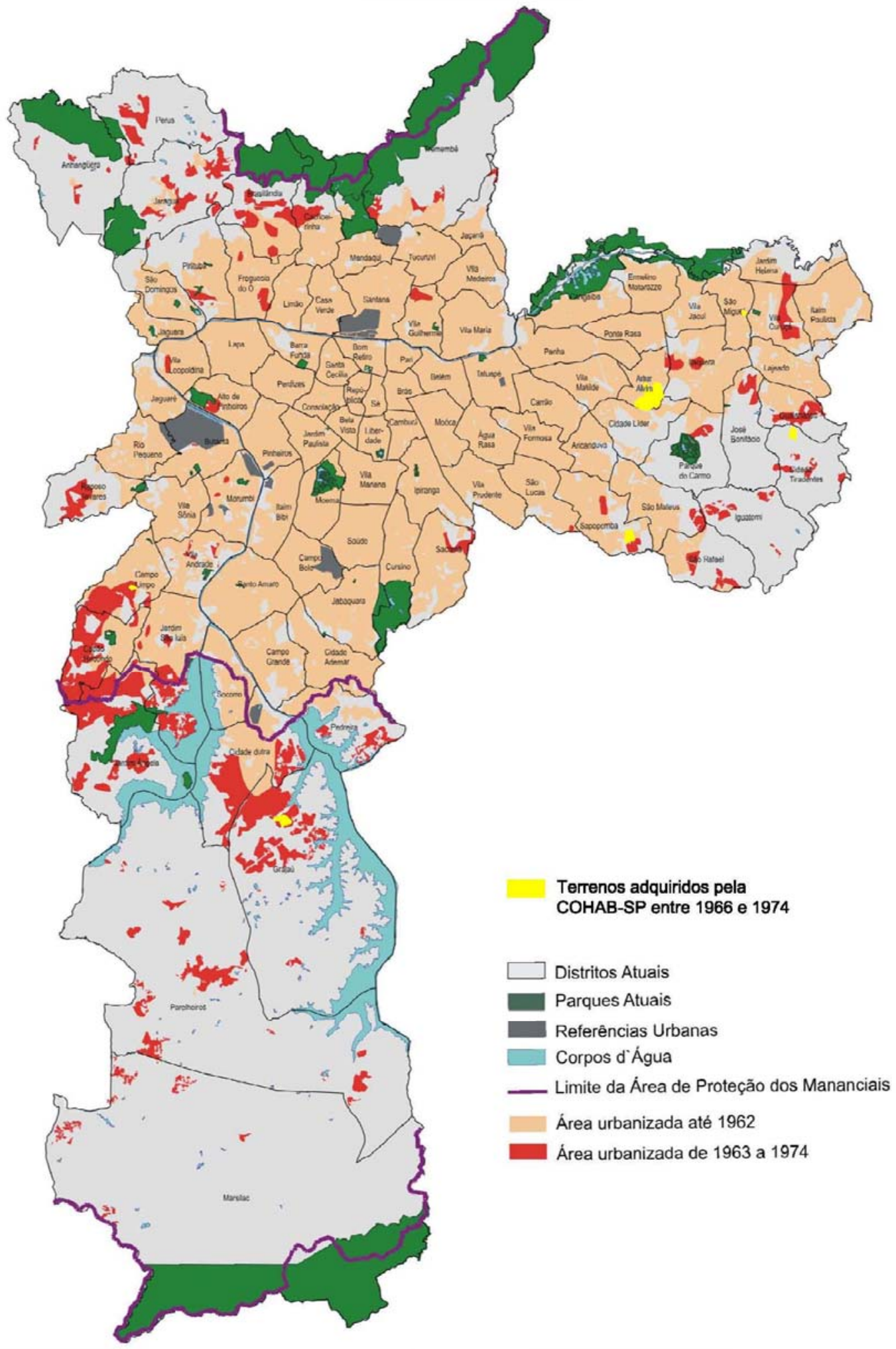

Fonte: SEMPLA/DIPRO - Secretaria Municipal de Planejamento/Departamento de Estatística e Produção de Informação Prefeitura do Município de São Paulo. Histórico Demográfico do Município de São Paulo. Acessado do sítio http://sempla.prefeitura.sp.gov.br/historico/ em 27 de fevereiro de 2008; SLOMIANSKY, Adriana Paula. Op. Cit., 2002. Elaboração: Estevam Otero 


\section{São Paulo: área urbanizada 1975-1985}

Terrenos adquiridos pela COHAB-SP entre 1975 e 1985

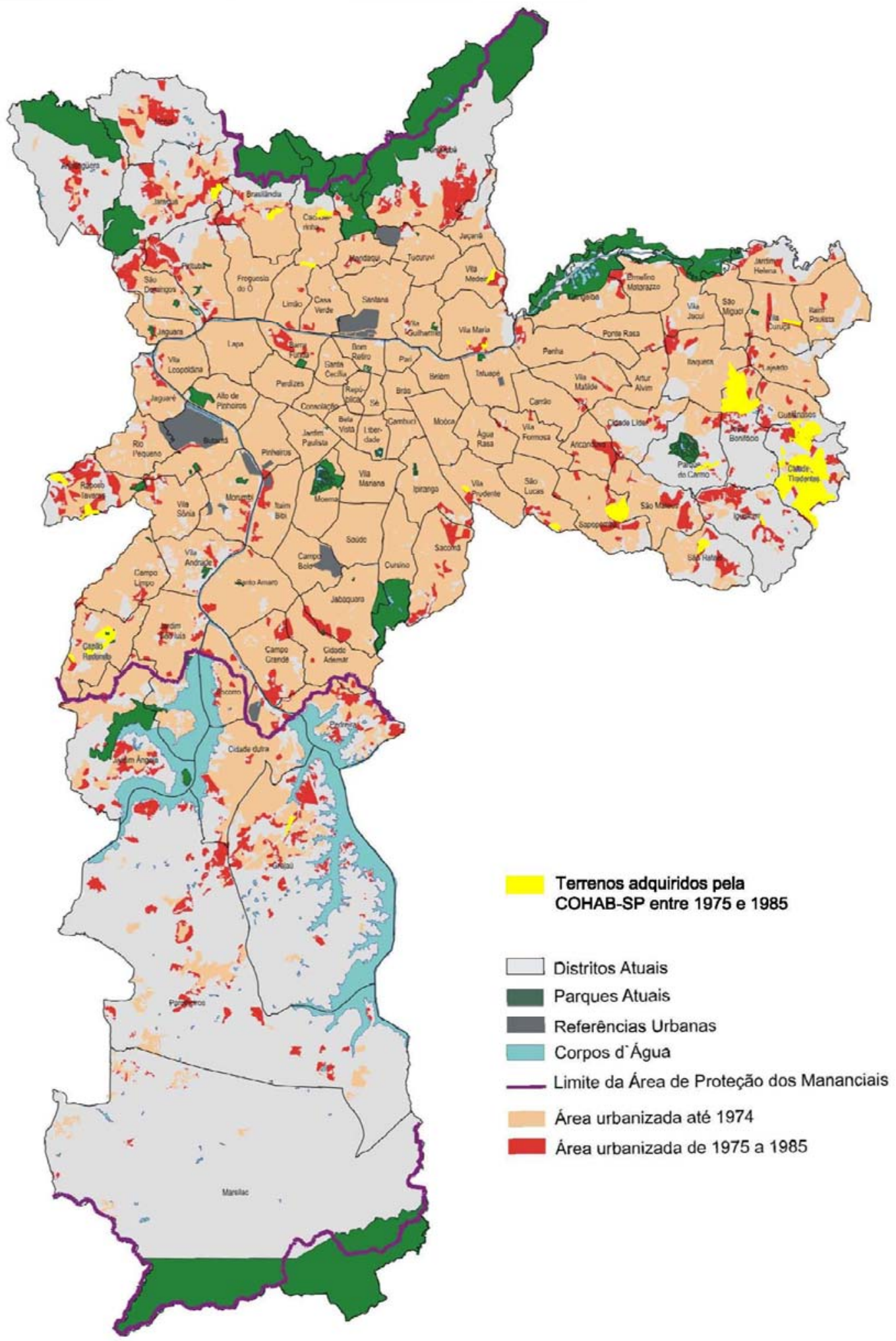

Fonte: SEMPLA/DIPRO - Secretaria Municipal de Planejamento/Departamento de Estatística e Produção de Informação Prefeitura do Município de São Paulo. Histórico Demográfico do Município de São Paulo. Acessado do sítio http://sempla.prefeitura.sp.gov.br/historico/ em 27 de fevereiro de 2008; SLOMIANSKY, Adriana Paula. Op. Cit., 2002.

Elaboração: Estevam Otero 
São Paulo: área urbanizada 1986-1992

Terrenos adquiridos pela COHAB-SP entre 1986 e 1996

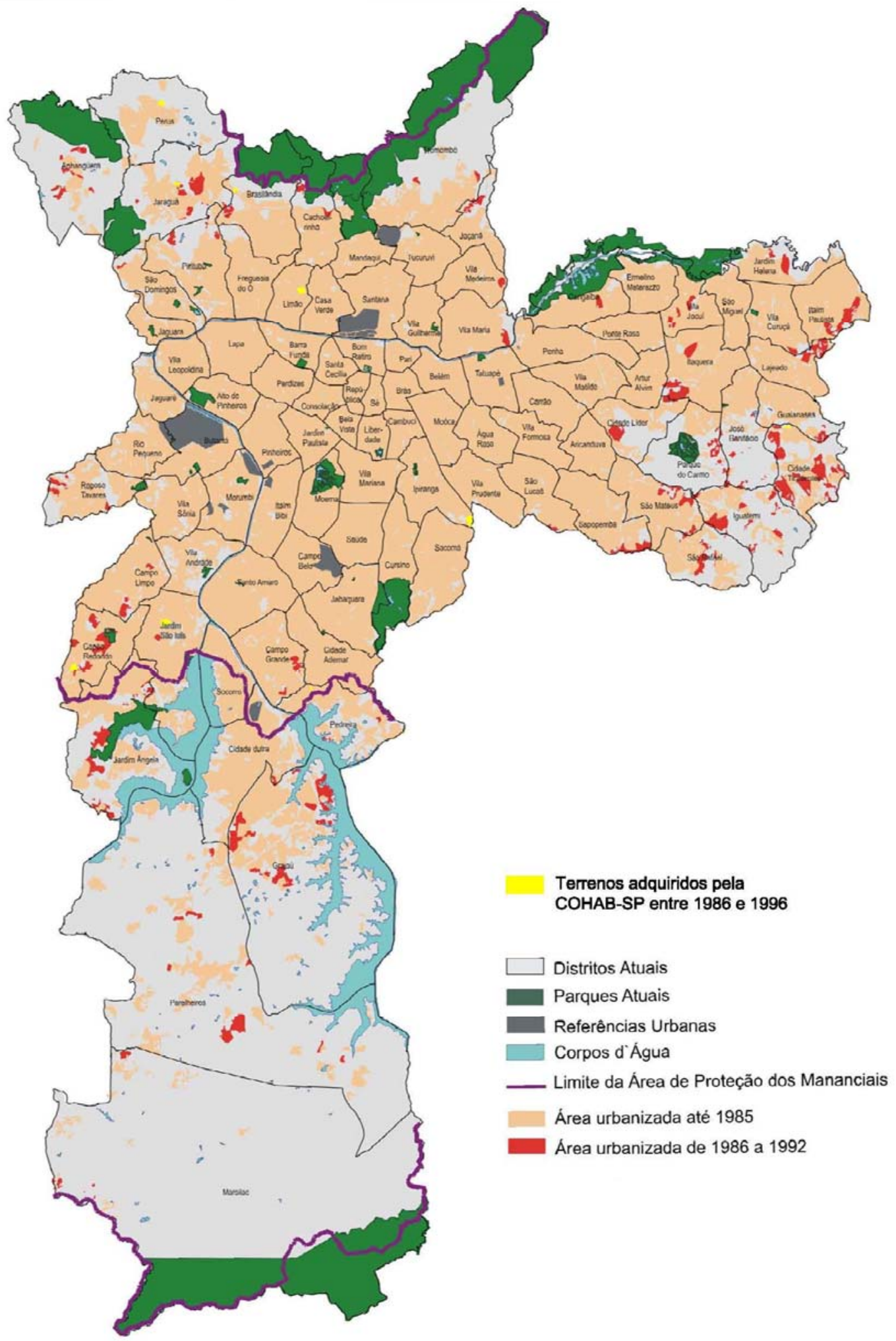

Fonte: SEMPLA/DIPRO - Secretaria Municipal de Planejamento/Departamento de Estatística e Produção de Informação Prefeitura do Município de São Paulo. Histórico Demográfico do Município de São Paulo. Acessado do sítio http://sempla.prefeitura.sp.gov.br/historico/ em 27 de fevereiro de 2008; SLOMIANSKY, Adriana Paula. Op. Cit., 2002.

Elaboração: Estevam Otero 
Já para MARICATO, essa reorientação do BNH teve três causas principais: em primeiro lugar, a grande concentração de renda no Brasil - que se acirrou ao longo de toda a década de 1970 - restringiu o boom imobiliário verificado no mercado privado aos setores de mais alta renda, atingindo seu limite e exaustão no fim dessa década pela própria exigüidade desse segmento populacional; em segundo lugar, verificou-se a pressão por parte das construtoras e indústrias de materiais e equipamentos para a construção civil, demandando que o BNH expandisse sua atuação voltada à produção em massa, numa manobra pela abertura de novos mercados em direção aos segmentos de menor renda; e, em terceiro lugar, a pressão exercida sobre o Estado pelos movimentos sociais urbanos por investimentos em moradia e em infra-estrutura ${ }^{42}$.

A produção dos grandes conjuntos habitacionais da COHAB-SP, ao mesmo tempo em que atendia a uma série de objetivos vinculados aos ganhos da indústria da construção civil, também trazia em seu bojo uma necessidade de legitimação por parte do governo autoritário de 1964 junto às camadas populares, num momento em que a oposição aglutinada no MDB - Movimento Democrático Brasileiro avançava eleitoralmente nesse contexto de distensão do regime.

Procedimento comum desde o período dos governos populistas, as unidades habitacionais populares construídas pela COHAB-SP eram moeda de troca importante na capitalização de ganhos políticos aos seus "promotores":

montado exclusivamente para pedir votos para o PDS e apoiar a dobradinha Reynaldo de Barros-Guilherme Afif Domingos, para o governo de São Paulo. Foi assim, a festa política que marcou a inauguração e entrega de 7.230 casas dos conjuntos habitacionais Itaquera II e III, pelo presidente João Figueiredo e centenas de políticos, na qual compareceram cerca de cinco mil pessoas - muito menos que o esperado. ${ }^{43}$

Paralela e diretamente relacionada à característica da localização dos conjuntos aparece o terceiro elemento que define essa promoção habitacional, qual seja, o déficit que essas áreas apresentam em infra-estrutura, equipamentos e serviços urbanos, além de postos de trabalho e pontos de consumo. Esses territórios constituídos a partir da intervenção do Estado, com um padrão de urbanidade bastante inferior ao da cidade consolidada, (re)produzem o diferencial de localizações, (re)alimentando o modelo segregador da metrópole paulista, sobrepondo "guetos" à distante periferia.

Segundo MARICATO, apesar da baixa qualidade arquitetônica e construtiva, a existência de uma razoável infra-estrutura implantada e equipamentos públicos nos

\footnotetext{
${ }^{42}$ Cf. MARICATO, Ermínia. Op. Cit., 1987, p. 56-7.

${ }^{43} \mathrm{O}$ Estado de São Paulo, 14 de fevereiro de 1982, p. 5.
} 
conjuntos da COHAB-SP os tornava bastante desejáveis se comparados às precárias condições ambientais e urbanas verificadas na periferia paulistana em fins das décadas de 1970 e início dos anos 1980. No ano de 1983 havia aproximadamente 300.000 inscritos na fila de espera por uma unidade habitacional da Companhia ${ }^{44}$. Contudo, parece-nos muito mais decisivo para esse interesse, como citado pela própria autora, o relativamente baixo preço das unidades da COHAB, que competia vantajosamente - em termos de custo com as demais opções disponíveis a essa população.

As precárias condições dos conjuntos habitacionais entregues pela COHAB-SP aos moradores fica evidenciada pela quantidade de informações veiculadas pela imprensa paulista à época da ocupação dos mesmos, especialmente daqueles na Zona Leste de São Paulo. No conjunto Prestes Maia, em Cidade Tiradentes, os moradores, em junho de 1982, reclamavam de vários aspectos:

do abandono do núcleo, onde a escola, o parque infantil, a creche e o recém inaugurado posto de saúde funcionam precariamente. O transporte é deficiente e $o$ abastecimento inexiste. (...) Cansados desta triste rotina e revoltados com a falta de transportes, agravada pela paralisação dos motoristas e cobradores (...) os moradores, na segunda-feira passada, puseram fogo à guarita do fiscal da Viação Tabu e ameaçaram depredar os ônibus. ${ }^{45}$

No conjunto Itaquera I, no mesmo ano, a prática do clientelismo político motivada pelas eleições para governador naquele ano levou o então prefeito Reynaldo de Barros a entregar as chaves de diversos prédios de apartamentos "antes mesmo da instalação da luz elétrica (...). Sem eletricidade, dezenas de famílias ficaram sem água, pois a bomba não podia encher as caixas, no alto dos prédios." 46

A busca pela construção da maior quantidade possível de unidades, possibilitada pelos recursos fartos do $\mathrm{BNH}$ e pela disponibilidade de terra barata, por vezes não eram acompanhados pelos necessários investimentos em infra-estrutura. O atraso na liberação do dinheiro para essa infra-estrutura - uma vez que, como visto anteriormente, os recursos destinados a essas obras eram independentes daqueles destinados à construção das unidades -, decorrente da relativa escassez que se abateu sobre o BNH no início dos anos 1980 gerou situações paradoxais:

O atraso de mais de um ano na abertura e pavimentação das ruas internas do Conjunto Habitacional Santa Etelvina está impedindo que 1.270 apartamentos e

\footnotetext{
${ }^{44}$ Cf. MARICATO, Ermínia. Op. Cit., 1987, p. 52.

${ }^{45}$ Folha de São Paulo, 18 de junho de 1982, p. 12.

${ }^{46}$ Folha de São Paulo, 21 de outubro de 1982, p. 19.
} 
3.378 casas já prontas, alguns desde março do ano passado, sejam entregues, por não haver no local nenhuma infra-estrutura. ${ }^{47}$

Esse descompasso financeiro entre as diferentes etapas de implantação do Conjunto Habitacional Santa Etelvina ficam claramente explicitadas pela passagem a seguir:

(...) a falta de infra-estrutura que começava a ser solucionada praticamente continua como estava. Aliás, os canos instalados pela Sabesp - o pouco que se conseguiu fazer - deverão ser reinstalados. Foram, basicamente, a falta de recursos do BNH e a conseqüente não-implantação de ruas asfaltadas, guias e sarjetas, além do sistema de águas e esgotos, os responsáveis pelas chuvas terem conseguido causar tantos estragos no conjunto habitacional. A construção não pára, se a infraestrutura não é implantada porque ambas dependem do BNH, mas são afeitas a duas diferentes administrações.

A política de constituição do estoque de terras da COHAB-SP, orientada por conveniências políticas ou pelo interesse de proprietários em se desfazer de terrenos sem compradores no mercado imobiliário, levou à aquisição de áreas absolutamente impróprias à implantação de conjuntos habitacionais. Some-se a esse fato a realização de projetos inadequados, o que fica bem representado pelo fato dos serviços de terraplenagem consumirem mais recursos que a compra dos terrenos em que eram realizados. Na mesma reportagem do Jornal da Tarde essa inadequação surge na descrição das fortes chuvas que praticamente destruíram a pouca infra-estrutura do complexo Santa Etelvina:

A água das chuvas causou prejuízos ainda incalculáveis para esse imenso conjunto habitacional (...). Ela veio descendo morro abaixo, forte e volumosa, causando erosões que demorarão muito tempo e custarão bastante para serem contidas. $O$ dinheiro e o trabalho de muitos meses, pode-se dizer, desmoronou junto com as águas.

(...) o terreno (é) acidentado e (era) coberto por mata cerrada. Ao cortarem essa mata, no início da implantação do projeto, entretanto, não foi tomado nenhum cuidado com o necessário desvio das águas das chuvas. O resultado é o quadro que se vê hoje: o terreno desmonta-se. O solo do tipo 'siltoso' (uma fina camada de argila sobre uma outra camada pouco resistente e que escoa facilmente com a água) praticamente 'derrete'. ${ }^{49}$

A precariedade da infra-estrutura, a que se somou a implantação de projetos inadequados - caso do conjunto Santa Etelvina - produziu situações dramáticas após cada chuva mais forte. No dia 3 de julho de 1989 a imprensa de São Paulo noticiava fatos praticamente idênticos aos do começo da década, estando o conjunto Cidade Tiradentes "ameaçado por 30 focos de erosão abertos pela chuva do final de semana (... e) as causas

\footnotetext{
${ }^{47}$ O Estado de São Paulo, 29 de março de 1983, p. 43.

48 Jornal da Tarde, 17 de junho de 1983, p. 14. O grifo é meu.

49 Jornal da Tarde, 17 de junho de 1983, p. 14.
} 
dos deslizamentos estão nas obras de terraplenagem, que não respeitaram as condições do terreno"50.

No mês de agosto de 1989 a COHAB-SP fez publicar um alerta de que uma catástrofe ambiental seria iminente caso não fosse resolvido o impasse em que se encontrava a situação da infra-estrutura em diversos conjuntos habitacionais da Companhia. A nova administração municipal, que havia tomado posse naquele ano, procurava pressionar a Caixa Econômica Federal, sucessora do extinto $\mathrm{BNH}$, pelo repasse dos recursos para a realização dessas obras de infra-estrutura.

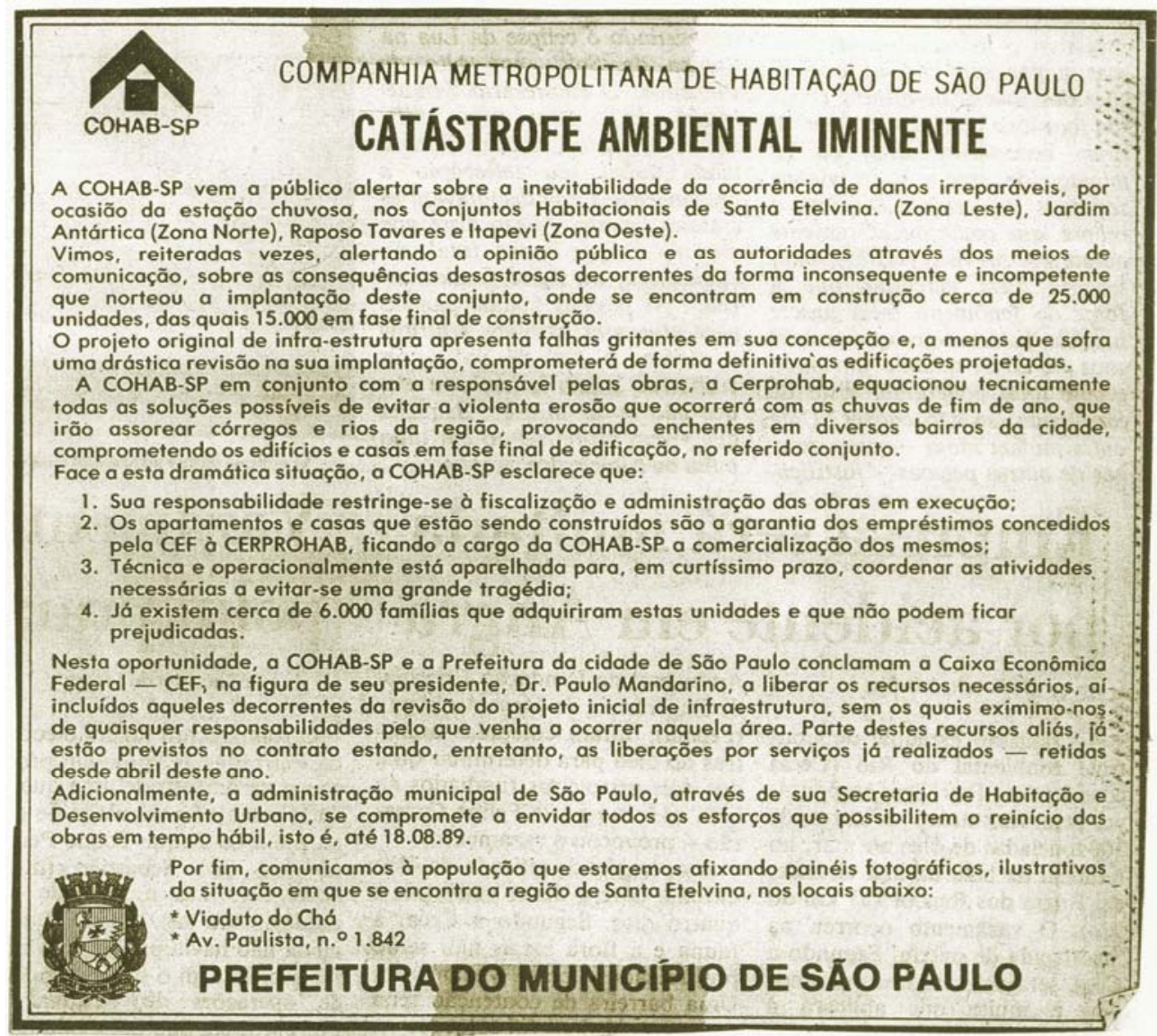

Imagem: Anúncio publicado pela COHAB-SP no jornal Folha de São Paulo no dia 18 de agosto de 1989, para alertar sobre o risco ambiental em diversos conjuntos habitacionais da companhia e pressionar a CEF por recursos.

A descrição das condições de moradia no espaço recém-entregue pelo poder público no conjunto habitacional da $\mathrm{COHAB}$ em Carapicuíba em pouco diferiam das descrições das periferias e favelas da Região Metropolitana:

As centenas de famílias que começaram ocupar os novos conjuntos habitacionais da Cohab, em Carapicuíba, já estão pedindo socorro às autoridades municipais e estaduais: as ruas não têm calçamento, falta iluminação pública, não contam com escolas, pronto-socorros e linhas de ônibus e, o que é pior, os moradores já

${ }^{50}$ O Estado de São Paulo, 3 de julho de 1989, p. 19. 
começaram a ser vítimas de assaltantes, uma vez que o patrulhamento ostensivo, a cargo da Polícia Militar, é muito reduzido. (...) As famílias estão sendo obrigadas a manter as crianças em casa, porque as escolas ficam muito longe e não existe previsão de quando elas serão implantadas. (...) os moradores precisam caminhar a pé quase seis quilômetros até os pontos terminais da linha circular que trafega na parte antiga do conjunto da Cohab. As empresas de transportes coletivos alegam que não ampliam as suas linhas porque as ruas não tem as mínimas condições de tráfego. (...) as famílias que chegaram com suas mudanças precisaram carregar nas mãos móveis e roupas, atravessando ruas que estavam transformadas em verdadeiro lamaçal. ${ }^{51}$

Dois dias depois era relatada a precária condição encontrada pelos moradores do conjunto Jardim Sapopemba, onde "180 apartamentos e perto de mil pessoas (encontravam-se) completamente sem acesso para veículos, a ponto de mudanças terem de ser feitas nos ombros." 52

É correto afirmar, porém, que as condições desiguais na oferta de infra-estrutura e equipamentos entre a cidade consolidada e a periferia vem se alterando profundamente ao longo das últimas décadas. O acesso à infra-estrutura básica, entre estes as redes de água e energia elétrica, praticamente se universalizaram, ainda que o ritmo dessa melhoria tenha se reduzido ao longo da década de 1990. CALDEIRA ilustra essa melhoria valendose de uma comparação da situação da periferia no começo da década de 1990 em relação a um estudo elaborado pela SEPLAN - Secretaria de Economia e Planejamento do Estado de São Paulo no ano de $1977^{53}$. Esse estudo, utilizando-se de dados do Censo/IBGE de 1970, identifica oito regiões "homogêneas" em relação a suas características urbanas e socioeconômicas, indo da região I - a mais central, rica e bem-equipada - à região VIII - a mais pobre, pior equipada e mais distante do centro, correspondendo atualmente a 28 distritos da Cidade de São Paulo ${ }^{54}$.

Em 1970, 22\% dos domicílios de São Paulo localizavam-se nessa região VIII, assim como $24,1 \%$ da população do município aí residia. Desses domicílios, apenas 19,1\% estavam conectados às redes de coleta de esgoto ${ }^{55}$. Segundo dados do Censo 1991, os distritos correspondentes a essa Região VIII concentravam, naquele ano, 28,84\% dos

\footnotetext{
${ }^{51}$ O Estado de São Paulo, 13 de maio de 1983, p. 15.

52 O Estado de São Paulo, 15 de maio de 1983, p. 25.

${ }^{53}$ CALDEIRA, Teresa Pires do Rio. Op. Cit., 2000, p. 228.

54 Cf. CALDEIRA, Teresa Pires do Rio. Op. Cit., 2000, p. 236. A área identificada como a Região VIII nesse estudo da Seplan de 1977 corresponde aos atuais distritos de Anhanguera, Brasilândia, Cachoeirinha, Cidade Dutra, Cidade Tiradentes, Ermelino Matarazzo, Grajaú, Guaianases, Iguatemi, Itaim Paulista, Itaquera, Jaraguá, Jardim Ângela, Jardim Helena, Jardim São Luis, José Bonifácio, Lajeado, Marsilac, Parelheiros, Parque do Carmo, Perus, Ponte Rasa, São Mateus, São Miguel, São Rafael, Socorro, Vila Curuçá e Vila Jacuí.
}

${ }^{55}$ Cf. CALDEIRA, Teresa Pires do Rio. Op. Cit., 2000, p. 230. 
domicílios e 31,75\% da população paulistana, ao passo que a rede de esgotos atingia já $74 \%$ desses domicílios ${ }^{56}$. Em 2000, essa região já representava pouco mais de um terço dos domicílios e dos habitantes da cidade de São Paulo: 35,29 e 37.90\%, respectivamente, enquanto a infra-estrutura de esgotos atingia 76,98\%. Segundo dados da Prefeitura de São Paulo, a cobertura no município como um todo passou de 75\% em 1991 para 89\% em 2000 , chegando a $96 \%$ de cobertura no ano de 2006 , o que nos leva a crer que essa expansão da rede tenha se dado na periferia ${ }^{57}$.

A desigualdade socioespacial, entretanto, vai muito além do atendimento às necessidades básicas de infra-estrutura, representando um todo que envolve das condições de acessibilidade e mobilidade intra-urbana à oferta de equipamentos públicos, de escolas e postos de saúde a espaços de lazer e cultura, passando pelos postos de trabalho e de consumo. Para MARQUES a redução efetiva das desigualdades espaciais e da segregação passa pela constituição de políticas públicas que efetivem um investimento maciço no sentido de equalizar as condições das diversas localizações na cidade.

A promoção habitacional pública por meio da COHAB-SP, como vimos, teve pouca relação com o expediente de redução do custo de reprodução da força de trabalho, uma vez que os conjuntos edificados pela Companhia encontram-se bastante distantes dos principais locais de concentração de empregos formais, em quaisquer setores de atividade econômica. Em alguns casos, a soma das precariedades e das péssimas condições de acessibilidade e mobilidade, como no complexo de Cidade Tiradentes, corresponderam a um verdadeiro "exílio econômico" na Metrópole. A COHAB-SP, paradoxalmente, produziu cidades-dormitório distantes e com acesso precário aos postos de trabalho, como pode-se ver no mapa da página seguinte.

Outra característica dos conjuntos habitacionais da COHAB-SP diz respeito à morfologia e tipologia resultante da produção dessa forma urbana. A partir da instituição do SFH/BNH tem-se uma inflexão na promoção habitacional, abandonando-se as experiências emblemáticas e (relativamente) bem-sucedidas realizadas ao longo das décadas de 1940 e 1950 pelos IAPs e pelo Departamento de Habitação Popular da Cidade do Rio de Janeiro, então Distrito Federal.

\footnotetext{
${ }^{56}$ Cf. CALDEIRA, Teresa Pires do Rio. Op. Cit., 2000, p. 237.

57 SEMPLA/DIPRO - Secretaria Municipal de Planejamento/Departamento de Estatística e Produção de Informação - Prefeitura do Município de São Paulo. Município em Dados. Acessado do sítio http://www9.prefeitura.sp.gov.br/sempla/md/ em 27 de fevereiro de 2008.
} 


\section{População residente, concentração de empregos formais e localização dos conjuntos da COHAB-SP na Cidade de São Paulo}

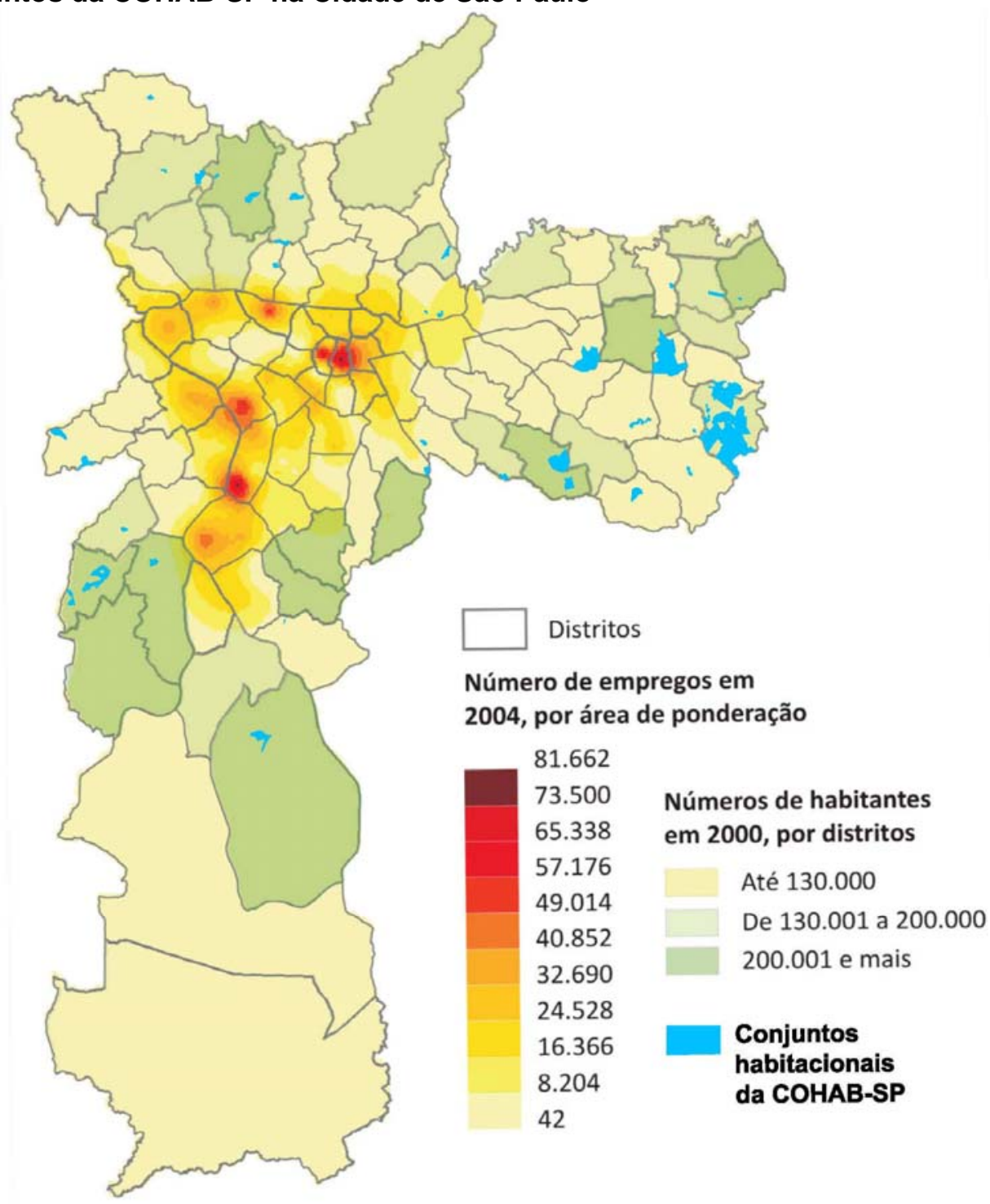

Fonte: SÂO PAULO (cidade). Secretaria Municipal de Planejamento - SEMPLA. Departamento de Estatística e Produção da Informação - DIPRO. Olhar São Paulo - contrastes urbanos. São Paulo: SEMPLA, 2007, p. 61 - Secretaria Municipal de Planejamento - Sempla/Dipro; IBGE - Censo Demográfico 2000; Ministério do Trabalho e Emprego - Relação Anual de Informações Sociais - Rais 2004. SLOMIANSKY, Adriana Paula. Op. Cit., 2002. Elaboração: Estevam Otero

A política habitacional nacional, marcadamente a partir do $\mathrm{BNH}$, passou a privilegiar um enfoque quantitativo, buscando a construção do maior número de unidades, no menor tempo e ao menor custo possível. O divórcio entre as políticas de desenvolvimento urbano e habitacional, centrada na produção de mais e mais unidades, deixou em último plano a possibilidade de constituir espaços integrados à malha e qualificados urbanisticamente. A lógica empresarial que dominava o $\mathrm{BNH}$ impunha a necessidade da maximização do número de novas unidades em detrimento de uma reflexão mais apurada acerca da urbanidade desses territórios. 
O Conjunto Habitacional Itaquera I é um marco dessa dinâmica, pois estabeleceu uma nova escala a esse tipo de empreendimento, em que a função residencial encontra-se hipertrofiada, resultando numa área monofuncional, onde vive uma população estimada em pouco mais de 62.000 habitantes, quase toda em apartamentos-padrão. Itaquera I representa a ruptura definitiva com um modelo que privilegiava - ou, ao menos, procurava uma inserção qualificada e qualificadora do ambiente urbano. A partir daí o privilégio dado à quantidade de novas unidades em detrimento da qualidade dos novos espaços urbanos foi absoluto, tornando-se um assunto muito mais de empresários da construção civil que de arquitetos $^{58}$.

Este conjunto foi edificado numa área de $2.700 .000 \mathrm{~m}^{2}$ cedida pelo INPS, integrando uma estratégia declarada de ocupação da periferia com grandes conjuntos residenciais, dotados de todos os serviços e equipamentos públicos necessários, com o intuito de tornar-se instrumento de sua requalificação ${ }^{59}$.

A concepção morfológica dos conjuntos edificados a essa época bebia na fonte do Movimento Moderno, tomando por inspiração o urbanismo funcionalista de Brasília, buscando a ruptura com as formas urbanas existentes em seu entorno. Em entrevista ao IPT, em 1984, o arquiteto de Itaquera I Jacob Aron Corch delineia a concepção urbanística que orientou seu projeto:

o conjunto é a linguagem da arquitetura moderna (...) No conjunto de Itaquera está inserida muito a idéia de Lúcio Costa, em Brasília, que é a idéia da superquadra habitacional. Superquadra é uma concepção básica aí no conjunto de Itaquera, porque não existe mais o pequeno lote, e ao invés do pequeno lote é a quadra com grandes espaços livres, com espaço de recreação, espaço para estacionamento, com eixos de circulação de áreas mais generosas, com uma preocupação com o trânsito de veículos, com uma preocupação em evitar o conflito de pedestres ou das pessoas com os veículos, com a preocupação das áreas verdes entremeando as edificações habitacionais, com a preocupação de vazios; não só com a construção propriamente dita, com os edifícios, que pudessem ser espaços de lazer, espaços de utilização das pessoas, das crianças, dos velhos, dos adolescentes etc. ${ }^{60}$

O discurso, que privilegia os espaços livres, a recreação, o pedestre, paradoxalmente, traduz-se em espaços em que a mobilidade a pé é constrangida pelas imensas distâncias que devem ser percorridas dentro do conjunto, uma vez que a profusão de áreas livres, pretensamente reservados ao lazer, e que permanecem por longo tempo

\footnotetext{
58 Cf. RUBANO, Lizete Maria. Cultura de projeto: um estudo das idéias e propostas para habitação coletiva. Tese de doutorado apresentada à Faculdade de Arquitetura e Urbanismo da Universidade de São Paulo. São Paulo: FAUUSP, 2001, p. 19.

${ }^{59}$ Cf. RUBANO, Lizete Maria. Op. Cit., 2001, p. 59.

${ }^{60}$ DAMIANI, Amélia Luisa. Op. Cit., 1993, p. 127.
} 
sem uso definido, desocupadas, tornam longos e penosos os deslocamentos, resultando num espaço fragmentado.

ORNSTEIN e ROMÉRO, ao realizar estudo de avaliação pós-ocupação no conjunto habitacional São Luiz, construído pela CDHU na Zona Sul de São Paulo, verificaram que as áreas livres e os equipamentos de lazer do mesmo não haviam sido executados, assim como a arborização do complexo. Somando-se a isso, a descuidada implantação dos edifícios residenciais em $H$, demandando grandes movimentações de terra para a constituição dos platôs, acabaram por gerar taludes de até sete metros de desnível. Esses espaços truncados e inadequados acabaram por transformar os bolsões de estacionamentos do conjunto nos únicos espaços de lazer e recreação, principalmente às crianças moradoras ${ }^{61}$.

Ainda que formulada para outro contexto, aquele dos subúrbios parisienses, a definição de LEFEBVRE é extremamente pertinente e adequada a esses grandes conjuntos habitacionais, uma vez que a aplicação desse ideário urbanístico do qual resulta esta forma representaria, paradoxalmente, uma "urbanização desurbanizante e desurbanizada", sendo que nos dois casos - nos conjuntos habitacionais paulistanos e nos subúrbios parisienses - o discurso subjacente é o da busca pela proximidade "da natureza, do sol e do verde" ${ }^{\text {"62 }}$.

Além disso, a lógica projetual assumida nesses conjuntos pressupunha uma vida rígida e regrada, sem espaço para as particularidades de cada família. Pressupôs-se que os novos moradores deveriam se adaptar ao ambiente construído, em lugar do projeto prever as necessidades específicas dessa população - o que seria impossível com a padronização dos projetos - ou ainda de se possibilitar algum tipo de flexibilidade que permitisse alguma forma de apropriação diferenciada pelos residentes.

LEFEBVRE capta precisamente os problemas representados pela extrema rigidez e inflexibilidade presentes nos programas dos conjuntos, embutidos na lógica funcionalista que subsidiou os projetos dos grandes conjuntos habitacionais, tanto na Europa quanto aqui:

As pessoas irão docilmente, como quer o plano, comprar no centro comercial, pedir conselho no centro social, brincar no centro de lazeres, realizar pontualmente os

\footnotetext{
${ }^{61}$ Cf. ORNSTEIN, Sheila Walbe e ROMÉRO, Marcelo de Andrade. Avaliação Pós-Ocupação: métodos e técnicas aplicados à habitação social (Coleção Habitare/FINEP). Porto Alegre: ANTAC, 2003, p. 86-7.

${ }^{62}$ LEFEBVRE, Henri. O Direito à Cidade. São Paulo: Centauro, 2001, p. 18.
} 
atos do cidadão no centro administrativo? (sem omitir o fato de que esses centros não existem ainda, senão sobre o papel, e que eles serão já um progresso!). ${ }^{63}$

Quando o discurso funcionalista modernista se converteu em decisão projetual inúmeras vezes ele se traduziu em espaços sem a mínima urbanidade, fruto de implantações equivocadas e soluções formais empobrecedoras. É o caso do Conjunto Habitacional Santa Etelvina I/VI-A, no distrito Cidade Tiradentes, onde os condomínios não estabelecem nenhuma relação com a rua e os espaços residuais são um fator a mais na degradação desses locais.

A violenta ampliação da escala desses empreendimentos, ao que se acrescentaram uma radical padronização tipológica e um uso estritamente residencial sob a égide do modernismo funcionalista, contribuiu à configuração desses espaços urbanos sob a forma de verdadeiros guetos. As decisões projetuais tomadas para a construção dos conjuntos da COHAB-SP dessa fase redundaram em espaços absolutamente rígidos e que impediam apropriações e adaptações por parte de seus moradores de forma a resultar em alguma forma de diversidade urbana.

A diversidade nas formas de uso e apropriação do espaço foi diagnosticada por JACOBS como o principal fator para a promoção e manutenção de uma vida urbana qualificada. Segundo sua análise "precisamos de todos os tipos de diversidade, intrincadamente combinados e mutuamente sustentados. Isso é necessário para que a vida urbana funcione adequada e construtivamente" ${ }^{\prime 64}$.

Segundo ela, os fatores geradores dessa diversidade urbana seriam resultado da

criação de uma quantidade inacreditável de pessoas diversas e de organizações privadas diversas, que têm concepções e propósitos bastante diversos e planejam e criam fora do âmbito formal da ação pública. A principal responsabilidade do urbanismo e do planejamento urbano é desenvolver - na medida em que a política e a ação pública o permitam - cidades que sejam um lugar conveniente para que essa grande variedade de planos, idéias e oportunidades extra-oficiais floresça, juntamente com o florescimento dos empreendimentos públicos. ${ }^{65}$

Essa possibilidade de realizar múltiplas intervenções e adaptações por parte dos moradores dos conjuntos habitacionais da COHAB-SP já estava legalmente interditada a priori. A rigidez dos projetos resultou em que todas as transformações por que passaram

${ }^{63}$ LEFEBVRE, Henri. Introduction a la modernité. Paris: Minuit, 1962, p. 123, apud DAMIANI, Amélia Luisa. Op. Cit., 1993, p. 149.

64 JACOBS, Jane. Op. Cit., 2000, p. 267. Apesar de tratar especificamente do caso norte-americano, sua análise pode ser transposta às cidades brasileiras sem maiores considerações.

${ }^{65}$ JACOBS, Jane. Op. Cit., 2000, p. 267. 
os condomínios ou as formas de apropriação dos espaços públicos ou particulares se dessem à margem da regulação oficial e dos projetos originais.

Além disso, a imediata identificação da morfologia dos conjuntos habitacionais é fator que induz e reforça a estigmatização dessas populações residentes, uma vez que delimita visualmente esse enclave em meio ao tecido metropolitano, caso de Cidade Tiradentes, onde o "acesso" e "conexão" do complexo de Santa Etelvina à cidade de São Paulo se dá a partir de uma única via, a Estrada do Iguatemi.

Por fim, outro elemento que impacta negativamente na qualidade ambiental e urbanística dos conjuntos habitacionais, com reflexos diretos nas desigualdades socioespaciais no território, é a condição das edificações, propriamente, resultado da qualidade dos materiais utilizados e da técnica construtiva empregada.

Encontramos um sem-número de exemplos na imprensa de São Paulo que explicitam as péssimas condições que os residentes nos conjuntos da COHAB-SP enfrentaram devido à baixíssima qualidade da construção dos edifícios e casas em que viviam. No conjunto habitacional Promorar da Vila Sabrina, na Zona Norte da capital, os quatro mil moradores do conjunto viam suas casa se desmanchando, onde "com menos de dois anos de uso muitas casas já estão escoradas por moirões para evitar que as paredes caiam. As que estão de pé apresentam rachaduras e se esfarelam ao menor toque de um dedo." 66

Aproximadamente oito anos após serem ocupados, os Conjuntos Itaquera I e II encontravam-se em estágio avançado de deterioração:

A péssima qualidade dos materiais utilizados resultou em grandes rachaduras e com isso paredes inteiras cedem vários centímetros a cada chuva. (...)

As escadas, que se tornaram uma das poucas opções de lazer para as crianças, provocam medo nas mães, pois já estão quase totalmente soltas das paredes dos prédios. ${ }^{67}$

O emprego de técnicas não-convencionais pela COHAB-SP com o intuito declarado de reduzir os custos da construção no preço final das unidades tornou-se um dos principais fatores de risco e deterioração dos conjuntos. O caso mais emblemático foi o da Construtora Coan Ltda., que foi contratada pela Companhia para a construção de três mil unidades entre 1980 e 83. Estudo realizado pelo IPT - Instituto de Pesquisas Tecnológicas em 1986 identificou "a inadequabilidade e incompatibilidade potencial dos

\footnotetext{
${ }^{66}$ Folha de São Paulo, 6 de janeiro de 1984, p. 18.

${ }^{67}$ O Estado de São Paulo, 19 de abril de 1986. O grifo é meu.
} 
materiais constituintes" 68 do sistema construtivo. Esse sistema foi empregado nos conjuntos habitacionais Fernão Dias, Vila Maria III, Carapicuíba VII, Itapevi, Barro Branco e Santa Etelvina.

Durante a administração Luiza Erundina à frente da Prefeitura paulistana, entre os anos de 1989-92, as unidades condenadas foram demolidas, representando 900 casas em Itapevi, 300 apartamentos no Santa Etelvina, 240 apartamentos no Castro Alves e 360 apartamentos em Carapicuíba, por absoluta falta de condições de serem ocupados ou recuperados ${ }^{69}$. Emblemático desse fracasso é o caso do conjunto Habitacional Castelo Branco, em Carapicuíba, onde dez edifícios foram implodidos devido ao risco que representavam.

A partir de meados da década de 1980, com a extinção do BNH e com o quadro recessivo que se instalou no país, a produção de unidades habitacionais novas caiu consideravelmente, ao passo que a população moradora em favelas cresceu em ritmo acelerado. Ao mesmo tempo, em paralelo, surgem programas alternativos de enfrentamento ao problema habitacional, especialmente relacionados à reurbanização de favelas.

O tempo da produção dos grandes conjuntos encerrou-se após a implantação do gigantesco complexo Santa Etelvina, no Distrito de Cidade Tiradentes, no extremo da Zona Leste de São Paulo, a partir do que a participação da Companhia na produção habitacional, sob a forma da construção de novas unidades, perdeu relevância frente a outras abordagens ${ }^{70}$.

\footnotetext{
${ }^{68}$ Relatório IPT 19.110 apud O Estado de São Paulo, 7 de abril de 1986, p. 28.

${ }^{69}$ Cf. Folha de São Paulo, 2 de maio de 1991, p. 4.1.

70 MARQUES e SARAIVA identificam essas novas abordagens de acordo com as diferentes administrações municipais que se sucederam à frente da Prefeitura da Cidade de São Paulo: na gestão de Luiza Erundina (1989-1992) foram privilegiados os mutirões, as urbanizações de favelas e as regularizações de loteamentos clandestinos. Mesmo nas gestões de Paulo Maluf (1993-1996) e Celso Pitta (1997-2000), a promoção de novas unidades esteve concentrada no Projeto de Urbanização de Favelas com Verticalização (Prover), conhecido por Projeto Cingapura, com financiamento do BID Banco Interamericano de Desenvolvimento e que, a despeito das críticas que sofreu - a grande maioria procedente, especialmente quanto ao seu caráter mais de marketing político que de solução adequada ao problema das favelas - tinha o mérito de estabelecer uma política de não remoção das favelas, com impactos significativos ao não promover a remoção das famílias moradoras.
}

Durante a gestão Marta Suplicy (2001-2004) os autores identificam o estabelecimento de uma série de programas, os quais geraram uma tendência à dispersão de esforços, com avanços, sobretudo na questão da regularização fundiária. Contudo, é neste momento que se estabelece um programa que busca fazer um enfrentamento dos problemas derivados dos equívocos cometidos quando da implantação dos grandes conjuntos da COHAB-SP nas décadas de 1970 e 1980: o Programa Viver Melhor. Cf. MARQUES, Eduardo e SARAIVA, Camila. Op. Cit., 2005, p. 275-288. 


\subsection{Ocupação e consolidação dos conjuntos habitacionais da COHAB-SP}

Passadas já algumas décadas desde o término da construção e da entrega dos grandes conjuntos habitacionais da COHAB-SP na cidade de São Paulo ${ }^{71}$ é notável um processo avançado de consolidação e apropriação do espaço pelos seus moradores, muitas vezes em contradição com as concepções originais dos mesmos, resultando em conflitos entre o projetado e o vivido nesses espaços.

As características intrínsecas à forma urbana representada pelos conjuntos habitacionais são determinadas pela extrema rigidez dos mesmos em relação às mudanças sociais e econômicas por que passa a cidade como um todo ao longo do tempo. A monofuncionalidade desses espaços, aliada à inflexibilidade quanto às novas demandas que se apresentam, leva a que as necessidades de adaptações e transformações impliquem, no mais das vezes, em irregularidades.

Uma realidade urbana marcada pelo conflito entre o projetado e as demandas contemporâneas da população - por amenidades cotidianas ou por meios de sobrevivência imediata -, num contexto de abandono desses locais pelo Estado após a conclusão das unidades habitacionais, pautou as intervenções dos residentes nos conjuntos, especialmente em relação às áreas condominiais.

Um dos primeiros e fundamentais conflitos estabelecidos nos conjuntos da COHAB-SP diz respeito à contradição entre os espaços projetados, tendo por base o privilégio à circulação dos automóveis, e a exigüidade de áreas de estacionamento para os veículos particulares.

Fisicamente, urbanisticamente, essas contradições se traduziram na ocupação das áreas condominiais dos edifícios por meio da privatização das áreas comuns, fundamentalmente para a constituição de áreas destinadas a estacionamento de veículos. Num segundo momento muitas dessas áreas foram convertidas em pontos comerciais, exploradas pelos próprios "proprietários" dessas vagas, ou alugadas a terceiros.

$\mathrm{Na}$ realidade, de acordo com as demandas específicas da população residente em cada conjunto, essa irregularidade na ocupação das áreas condominiais traduz-se de forma diversa: no caso do conjunto Itaquera I, implantado num contexto metropolitano mais central e com um perfil populacional de renda mais elevado que em Cidade Tiradentes, por

\footnotetext{
${ }^{71} \mathrm{O}$ conjunto Itaquera IA - primeiro dos grandes conjuntos da COHAB-SP e paradigmático na mudança de escala dos mesmos - teve suas obras concluídas em fins dos anos 1970, enquanto o Complexo de Cidade Tiradentes, com seus inúmeros conjuntos, ainda apresentava obras de escala considerável em execução até meados dos anos 1990, sendo que 93,2\% das unidade foram concluídas até 1992 . Cf. USINA-Ctah. Programa Bairro Legal: Plano de Ação Habitacional e Urbano - Diagnóstico. São Paulo: SEHAB/PMSP, 2003, p. 31.
} 
exemplo, a principal demanda é por vagas de estacionamento, refletida na forma predominante de irregularidade na ocupação das áreas comuns para constituição dos mesmos. No caso do complexo de Cidade Tiradentes, apesar da também crescente demanda por estacionamentos, o perfil principal dessa irregularidade vem sendo o estabelecimento de pontos comerciais nos muros dos condomínios ${ }^{72}$.

Além das áreas condominiais verifica-se uma contínua ocupação das áreas públicas - originalmente destinadas à implantação de equipamentos ou reservadas a empreendimentos da própria COHAB-SP - com os mesmos fins relatados anteriormente. Nossa pesquisa de campo pôde constatar que essas ocupações irregulares são objeto de um intenso "mercado" de locação e venda de pontos comerciais, criando uma dinâmica imobiliária própria.

Estabeleceremos uma análise mais detida acerca das condições atuais do complexo Cidade Tiradentes, as transformações e a consolidação dos grandes conjuntos localizados nesse distrito, uma vez que a própria importância quantitativa - e simbólica dessa concentração de conjuntos levou à constituição das mais significativas propostas e experiências de requalificação urbanística e ambiental de São Paulo, e que serão analisadas e avaliadas no capítulo seguinte.

As características próprias de Cidade Tiradentes, que exacerbaram os traços distintivos da produção da COHAB-SP, levando ao limite as contradições de seu modelo de ação, permitem compor um quadro muito rico das condições de segregação e alienação urbanas a que estão submetidos vastos contingentes populacionais da periferia de São Paulo, particularmente nos conjuntos habitacionais.

\subsubsection{Ocupação e consolidação do Complexo Cidade Tiradentes}

Cidade Tiradentes localiza-se no extremo leste da Cidade de São Paulo, divisa com o município de Ferraz de Vasconcelos. Quando da decisão de se implantar esse grande conjunto aquela região apresentava características rurais, com pequena população e uma intensa cobertura florestal. A região possui um relevo ondulado, com a presença de um tipo de solo extremamente suscetível à erosão, e grandes dificuldades para a execução

\footnotetext{
72 Estas informações foram fornecidas pelo ex-diretor de Patrimônio da COHAB-SP durante a gestão Marta Suplicy (2001-2004) Altemir Almeida, em entrevista realizada em 03 de setembro de 2008. Segundo ele, durante aquela administração foi realizada uma reunião na Subprefeitura da Penha (onde está localizado o conjunto Itaquera I) para debater o problema das irregularidades na ocupação das áreas condominiais (cuja fiscalização cabe, legalmente, à Subprefeitura), sem passar, entretanto, dessa primeira fase de reconhecimento do problema para alguma ação de regularização.
} 
de cortes e aterros ${ }^{73}$. Ainda assim, a opção projetual deu-se pela implantação dos modelos padronizados da Companhia, realizando-se grandes movimentações de terra para a implantação dos blocos de apartamento - forma predominante dentre os conjuntos - em patamares absolutamente desarticulados da topografia original. A própria implantação dos edifícios e sua orientação no terreno têm mais a ver com a constituição dos patamares de terraplenagem do que a orientação solar ou a relação com o sistema viário. No tópico 3.2 "A promoção habitacional pública na produção do espaço urbano metropolitano" já tratamos do desastre ambiental representado por essas decisões, tanto nos impactos ambientais quanto em sua relação com os custos finais da infra-estrutura demandada e realizada (mais de uma vez) devido às péssimas condições geotécnicas da área.
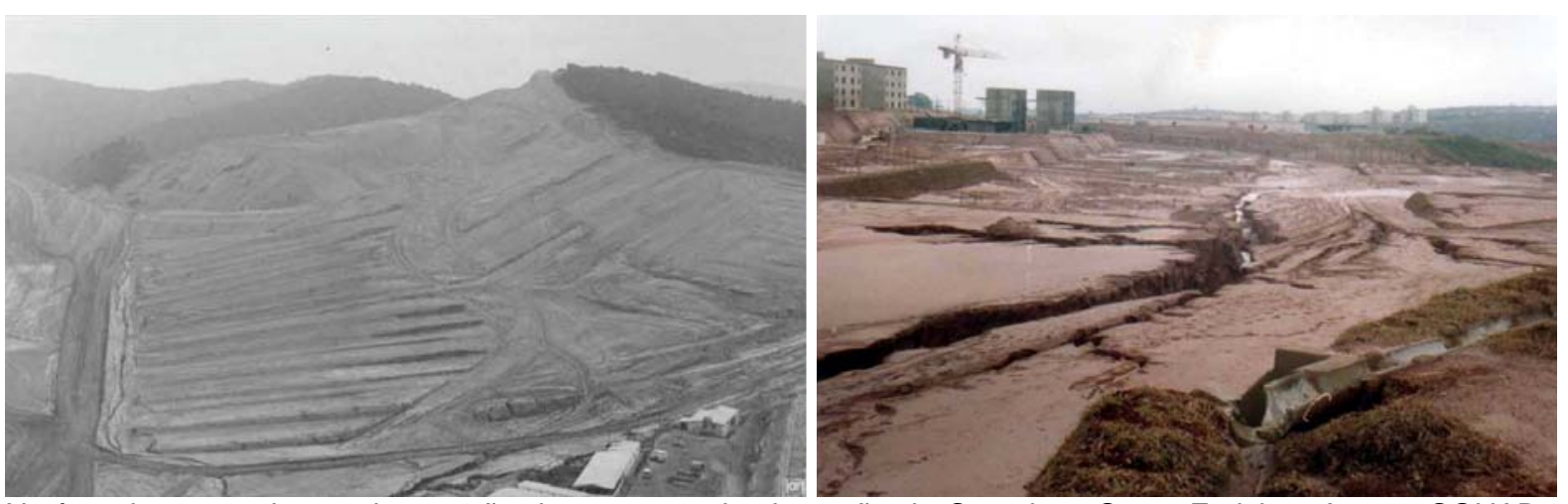

Na foto da esquerda, movimentação de terra para implantação do Complexo Santa Etelvina. Acervo COHABSP apud ZANDONADE, Patrícia. Conjuntos Habitacionais no Tecido Urbano da Metrópole de São Paulo: o caso da Região Leste (1930/1986). Dissertação de mestrado apresentada à Faculdade de Arquitetura e Urbanismo da Universidade de São Paulo. São Paulo: FAUUSP, 2008, p. 133. À direita, erosões provocadas pelas chuvas em Cidade Tiradentes in . USINA-Ctah. Op. Cit., 2003, p. 39.

A subprefeitura de Cidade Tiradentes, integrada unicamente pelo distrito de mesmo nome, apresentava uma população de 190.657 habitantes no ano de 2000, segundo dados do Censo IBGE realizado naquele ano. Em 1980 o distrito contava com apenas 8.603 moradores: uma verdadeira explosão demográfica, de mais de $2.000 \%$ em apenas $20 \operatorname{anos}^{74}$. Desse total, cerca de três quartos, aproximadamente 150.000 habitantes, residem no distrito em algum dos seus diversos conjuntos habitacionais ${ }^{75}$.

73 Maciços de solo e rocha xisto-micáceos. Cf. SEMPLA/DIPRO - Secretaria Municipal de Planejamento/Departamento de Estatística e Produção de Informação - Prefeitura do Município de São Paulo. Município em Mapas - Panorama - Mapa 2: Maciços de Solo e Rocha. Acessado do sítio "http://sempla.prefeitura.sp.gov.br/mm/panorama/" em 19 de novembro de 2008.

74 IBGE, Censos Demográficos, 1980, 1991 e 2000/Estimativa Sempla/Dipro com base no saldo vegetativo e tx. de crescimento 91/2000, in: SEMPLA/DIPRO - Secretaria Municipal de Planejamento/Departamento de Estatística e Produção de Informação - Prefeitura do Município de São Paulo. Município em Dados. Acessado do sítio "http://www9.prefeitura.sp.gov.br/sempla/md/" em 27 de fevereiro de 2008.

${ }^{75}$ Cf. USINA-Ctah. Op. Cit., 2003, p. 30. 


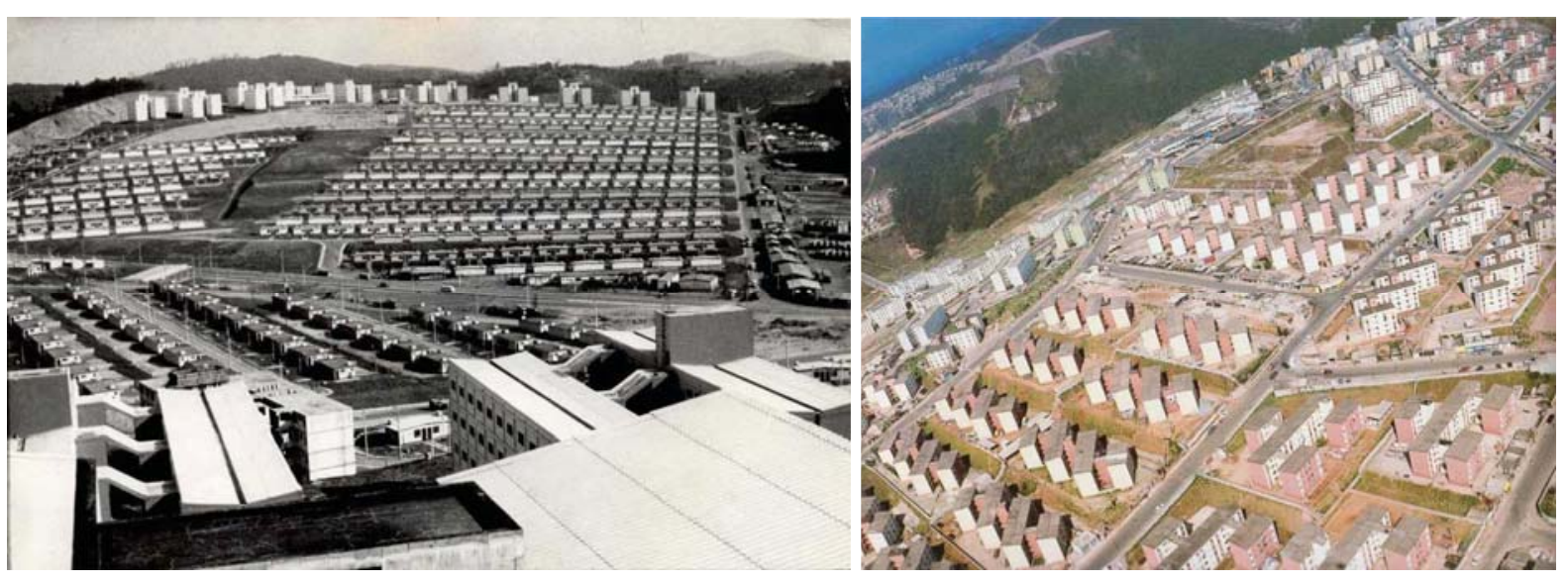

$\mathrm{Na}$ foto da esquerda, conjunto Jardim São Paulo/Juscelino Kubitschek, em 1982. Acervo COHAB-SP apud ZANDONADE, Patrícia. Op. Cit., 2008, p. 151. À direita, vista aérea atual dos conjuntos Santa Etelvina I/VIA e VII in . USINA-Ctah. Op. Cit., 2003, p. 30.

No distrito foram implantados 14 conjuntos habitacionais pela COHAB-SP, entre os anos de 1975 e 1998, totalizando 42.379 unidades, quase um terço de toda a produção da Companhia ao longo de sua história ${ }^{76}$. Na tabela na página seguinte podemos observar mais detalhadamente as características desses conjuntos.

Em Cidade Tiradentes a tipologia predominante é a habitação coletiva em prédios laminares de quatro andares, significando 29.768 apartamentos, 70,2\% de todas as unidades produzidas aí pela COHAB-SP em todos os catorze conjuntos. O segundo padrão mais comum no distrito são as casas-embrião, que representam 10.170 unidades, ou 24\% do total. Apenas nos conjuntos Santa Etelvina IIB e IIIA não foram implantadas unidades desse modelo. Menos representativos são os lotes urbanizados, em número de 2.441 em apenas três conjuntos: Inácio Monteiro, Barro Branco II e Santa Etelvina VIII. Os lotes urbanizados representam apenas $5,8 \%$ do total de unidades habitacionais de Cidade Tiradentes.

A localização do distrito e a insuficiência do sistema viário que o conecta à cidade consolidada acabaram por se traduzir em um dos maiores tempos de deslocamento da cidade de São Paulo. Esse fato, associado a um dos mais baixos índices de mobilidade ${ }^{77}$, confere uma característica de isolamento dessa população em relação ao restante da cidade.

76 A COHAB-SP é responsável pela produção de 135.636 unidades habitacionais na Região Metropolitana de São Paulo. Cf. SILVA, Maria da Graça Plenamente. A "irregularidade" na produção de conjuntos habitacionais de interesse social: o caso da COHAB-SP. Dissertação de mestrado apresentada à Faculdade de Arquitetura e Urbanismo da Universidade de São Paulo. São Paulo: FAUUSP, 2004, Anexo.

77 Segundo dados da Pesquisa Origem Destino do Metrô 1997, um morador de Cidade Tiradentes realizava, em média, 1,2 viagens diariamente. Para efeito de comparação, um residente em Pinheiros realizava 4,2 viagens cotidianamente. Cf. USINA-Ctah. Op. Cit., 2003, p. 45. 


\section{Conjuntos Habitacionais da COHAB-SP em Cidade Tiradentes}

\begin{tabular}{|c|c|c|c|c|c|c|c|c|}
\hline $\begin{array}{c}\text { Conjunto habitacional COHAB- } \\
\text { SP }\end{array}$ & $\begin{array}{c}\text { Área da } \\
\text { gleba (ha) }\end{array}$ & $\begin{array}{l}\text { Zona de } \\
\text { uso }\end{array}$ & $\begin{array}{c}\text { Data da } \\
\text { aquisição } \\
\text { do terreno }\end{array}$ & $\begin{array}{c}\text { Área do } \\
\text { conjunto } \\
\text { (ha) }\end{array}$ & $\begin{array}{l}\text { Início das } \\
\text { obras }\end{array}$ & $\begin{array}{l}\text { Término } \\
\text { das obras }\end{array}$ & Un & lades Habitacionais \\
\hline \multirow{2}{*}{ Prestes Maia } & \multirow{2}{*}{20,9} & \multirow{2}{*}{$\mathrm{Z2}$} & \multirow{2}{*}{1968} & \multirow{2}{*}{20,9} & \multirow{2}{*}{1975} & \multirow{2}{*}{1980} & \multirow{2}{*}{1.260} & 260 apartamentos \\
\hline & & & & & & & & 1.000 casas/embriões \\
\hline \multirow{2}{*}{ Juscelino Kubitschek } & \multirow{2}{*}{79,6} & \multirow{2}{*}{ Z8 100/1 } & \multirow{2}{*}{1977} & \multirow{2}{*}{79,6} & \multirow{2}{*}{1979} & \multirow{2}{*}{1986} & \multirow{2}{*}{4.494} & 3.060 apartamentos \\
\hline & & & & & & & & 1.434 casas/embriões \\
\hline \multirow{2}{*}{ Santa Etelvina I/VIA } & \multirow{2}{*}{199,8} & \multirow{2}{*}{ Z8 100/1 } & \multirow{2}{*}{1978} & \multirow{2}{*}{124,2} & \multirow{2}{*}{1981} & \multirow{2}{*}{1986} & \multirow{2}{*}{5.155} & 3.760 apartamentos \\
\hline & & & & & & & & 1.395 casas/embriões \\
\hline \multirow{2}{*}{ Santa Etelvina IVA } & \multirow{2}{*}{100,3} & \multirow{2}{*}{ Z8 100/1 } & \multirow{2}{*}{1979} & \multirow{2}{*}{100,3} & \multirow{2}{*}{1981} & 1004 & 270 & 1.440 apartamentos \\
\hline & & & & & & 1984 & 2.103 & 1.263 casas/embriões \\
\hline & & & 1978 & & 1982 & 1984 & 1624 & 936 apartamentos \\
\hline Santa Etelvina VA & 114,2 & $\angle 8100 / 1$ & $19 / 8$ & 114,2 & 1982 & 1984 & 1.624 & 688 casas/embriões \\
\hline Cactro Alues Rarro Rranco I & 1206 & $70100 / 1$ & 1070 & 168 & 1002 & 1096 & 2101 & 960 apartamentos \\
\hline Castro Alves - Barro Branco I & 128,6 & $\angle 8$ 100/1 & $19 / 9$ & 46,8 & 1983 & 1986 & 2.184 & 1.224 casas/embriões \\
\hline Santa Etelvina IIIA & 100,9 & Z8 100/1 & 1979 & 32,4 & 1984 & 1986 & 2.080 & 2.080 apartamentos \\
\hline & & & & & & & & 844 apartamentos \\
\hline Inácio Monteiro & 55,4 & Z8 100/1 & 1985 & 55,4 & 1986 & 1999 & 2.333 & \begin{tabular}{|l|}
1.228 casas/embriões \\
261 lotes urbanizados \\
\end{tabular} \\
\hline Sítin Conceicão & 250 & $78100 / 1$ & 1082 & 250 & 1007 & 1090 & 1070 & 576 apartamentos \\
\hline SItio Concelção & 25,9 & $\angle 8100 / 1$ & 1982 & 25,9 & 1987 & 1989 & 1.078 & 502 casas/embriões \\
\hline Santa Etelvina IIA & 1120 & $78100 / 1$ & 1982 & & & & & 7.024 apartamentos \\
\hline Santa Etelvina IIA & 112,0 & $\angle 8100 / 1$ & 1982 & 84,3 & 1988 & 1992 & 7.441 & 417 casas/embriões \\
\hline & & & & & & & & 660 apartamentos \\
\hline Barro Branco II & 128,6 & Z8 100/1 & 1979 & 78,0 & 1987 & 1998 & 2.849 & 865 casas/embriões \\
\hline & & & & & & & & 1.324 lotes urbanizados \\
\hline Santa Etelvina IIB & 23,0 & Z8 100/1 & 1982 & 23,0 & 1988 & 1992 & 2.480 & 2.480 apartamentos \\
\hline & & & & & & & & 5.088 apartamentos \\
\hline Santa Etelvina VII & 74,2 & Z8 100/1 & 1982 & 74,2 & 1988 & 1996 & 6.098 & 154 casas/embriões \\
\hline & & & & & & & & 856 lotes urbanizados \\
\hline Jardim dos Ipês & 3,4 & Z8 100/1 & 1996 & 3,4 & 1996 & 1998 & 600 & 600 apartamentos \\
\hline TOTAIS & 1166,8 & & & 862,6 & 1975 & 1998 & 42.379 & \\
\hline
\end{tabular}

Fonte: SILVA, Maria da Graça Plenamente. Op. Cit., 2004.

SLOMIANSKY, Adriana Paula. Op. Cit., 2002, p. 123.

COHAB-SP. Conjuntos Habitacionais: Zona Leste. Acessado em 22 de dezembro de 2007 do site: http://www6.prefeitura.sp.gov.br/empresas_autarquias/cohab/conjuntos_habitacionais/zona_leste/0001.

Elaboração: Estevam Otero

Se de um lado, em termos de macroacessibilidade metropolitana, os moradores enfrentam o problema das grandes distâncias e do isolamento geográfico, quanto à dinâmica da microacessibilidade interna ao distrito são evidentes dificuldades semelhantes, devido à implantação dos distintos conjuntos como unidades isoladas e desconexas entre si, separadas por grandes vazios sem nenhuma urbanidade. Esses fatos tornam-se especialmente relevantes num contexto como o de Cidade Tiradentes que apresentava, segundo a Pesquisa Origem Destino 1997, a maior proporção de viagens a pé em São Paulo, representando $55 \%$ do total de viagens dos moradores ${ }^{78}$.

${ }^{78}$ Cf. USINA-Ctah. Op. Cit., 2003, p. 43. 

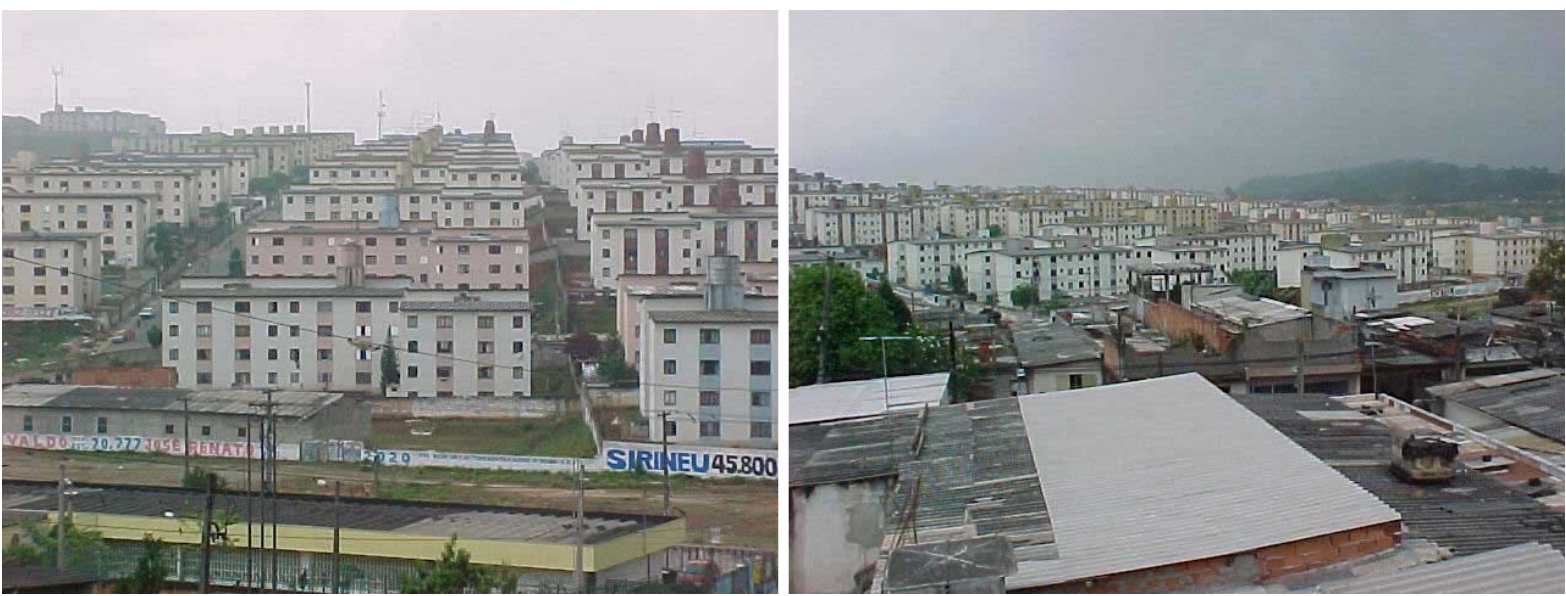

Santa Etelvina IIA. Foto: Estevam Otero, outubro de 2002.

Devido à localização do distrito, distante 25 quilômetros em linha reta do centro de São Paulo, e desarticulado do sistema de circulação da metrópole, os moradores de Cidade Tiradentes vivem um verdadeiro exílio metropolitano. O acesso ao distrito e sua conexão com a cidade de São Paulo se dá apenas pela Estrada do Iguatemi e avenida Ragueb Chohfi, que fazem sua ligação à avenida Aricanduva; a ligação com o distrito vizinho de Guaianases se dá pelo sistema de vias locais de Cidade Tiradentes.

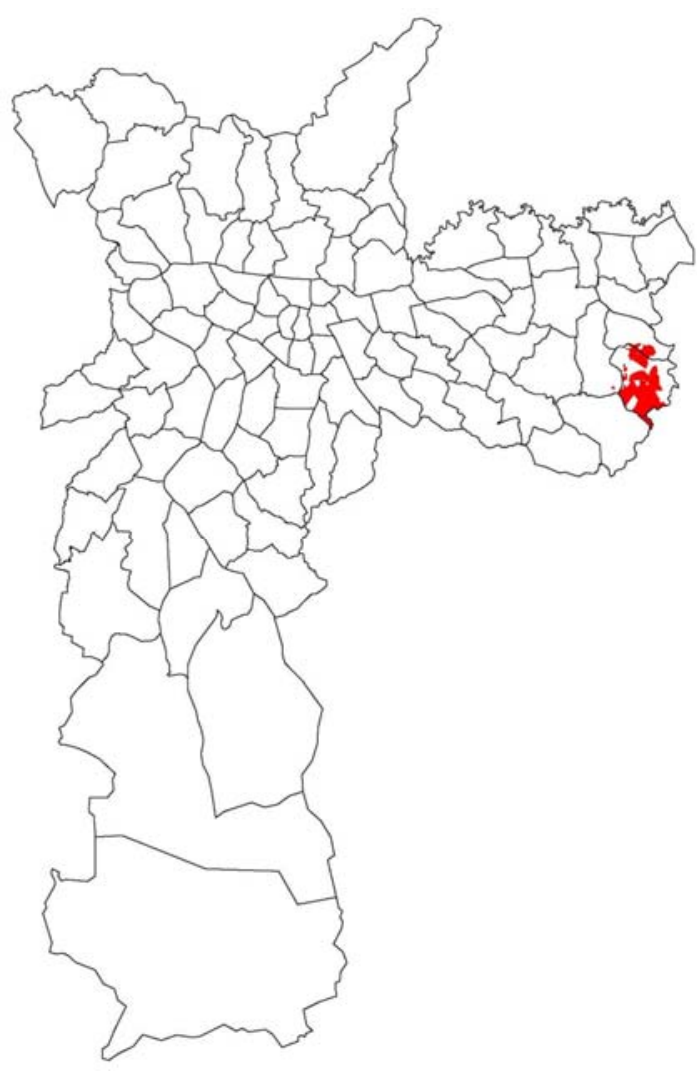

Localização do Complexo Cidade Tiradentes no município de São Paulo 


\section{Conforme observa SLOMIANSKY,}

o Complexo Cidade Tiradentes é um conglomerado carente de pontos de referência organizadores do espaço, que resultou da simples adição das chamadas tipologias de implantação, adaptadas às características topográficas do terreno ${ }^{79}$.

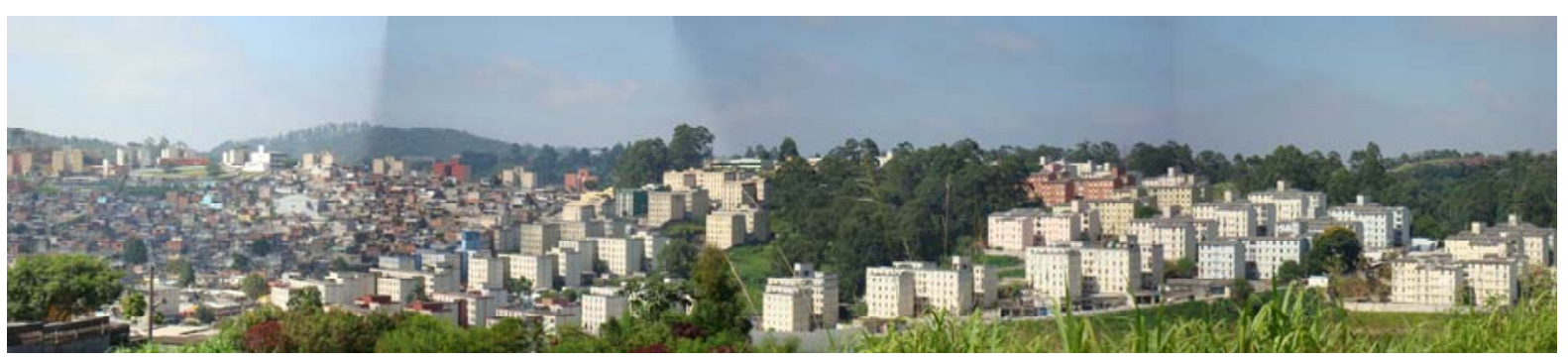

Vista panorâmica dos conjuntos Santa Etelvina IVA (à esquerda) e III-A, a partir da avenida dos Têxteis. Foto: Estevam Otero, fevereiro de 2008.

Desse modo, a vida cotidiana em Cidade Tiradentes fica condicionada por sua inserção distante e isolada da centralidade metropolitana, que dificulta seu acesso aos equipamentos, postos de trabalho, centros de consumo e amenidades da cidade consolidada. Além disso, sua configuração espacial, resultado de uma implantação "desurbanizante e desurbanizada", nos termos de LEFEBVRE, contribui para a fragmentação do espaço, pontuado por conjuntos de alta densidade e grandes vazios à espera de alguma utilização.

Essas características de isolamento e fragmentação tornam-se particularmente problemáticas na medida em que o distrito é habitado, majoritariamente, por uma população com rendimentos de médio-baixo a baixo. Em Cidade Tiradentes, segundo dados do Censo 2000 do IBGE, 57,39\% dos domicílios apresentavam renda familiar inferior a 5 salários mínimos, sendo que 20,47\% do total de domicílios apresentavam renda ainda menor, de até 2 S.M. Tomando por referência a população com renda de até 10 S.M. temos quase $90 \%$ dos domicílios do distrito abaixo dessa faixa de rendimento ${ }^{80}$.

\footnotetext{
${ }^{79}$ SLOMIANSKY, Adriana Paula. Op. Cit., 2002, p. 140.

${ }^{80} 88,62 \%$ dos domicílios de Cidade Tiradentes apresentam renda familiar de até 10 S.M. Essa proporção só é superada nos distritos de Lajeado (89,14\%), Parelheiros $(90,01 \%)$ e Marsilac $(94,79 \%)$. Se tomarmos essa proporção em relação à concentração de domicílios com renda familiar de até 5 S.M., Cidade Tiradentes é superado apenas pelos distritos de Grajaú $(58,79 \%)$, Jardim Ângela $(60,23 \%)$, Parelheiros (64,22\%) e Marsilac (75,32\%), na Zona Sul, e Lajeado (63,34\%) e Itaim Paulista $(60,28 \%)$ na Zona Leste. Cf. SEADE - Fundação Sistema Estadual de Análise de Dados. Distribuiçãa dos Domicílios, por Faixas de Renda Familiar, segundo Distritos - Município de São Paulo 2000. Acessado no site http://www.seade.gov.br/produtos/msp/index.php?tip=met4\&opt=s\&subtema=null\&tema=CVI e baixado em 25 de novembro de 2008.
} 
No ano $2000,20,94 \%$ dos moradores de Cidade Tiradentes eram considerados pobres, e 9,51\% indigentes ${ }^{81}$. No município de São Paulo, no mesmo ano, a média de pobres era de $12,06 \%$ do total da população, enquanto os indigentes eram $5,60 \%{ }^{82}$. Os baixos rendimentos do distrito ficam parcialmente demonstrados pelo alto índice de desemprego aí verificado. No ano 2000, Cidade Tiradentes apresentava o quarto maior nível de desemprego da cidade de São Paulo: 25,2\% da população com 15 anos ou mais. Dentre os vinte distritos com maiores índices desemprego, com exceção de Anhanguera, todos se localizavam nos extremos Leste e Sul da cidade. Entre a população do distrito na faixa de 18 a 24 anos, o desemprego atingia 35,1\% do total, enquanto na faixa de 25 a 59 anos $19,3 \%$ estavam desempregados. Para efeito de comparação, a média no município de São Paulo, nesse mesmo ano, era de $26,3 \%$ da população entre 18 e 24 anos de idade desempregada. Na faixa entre 25 e 59 anos o desemprego atingia $13,2 \%$ da população ${ }^{83}$.

O afastamento dos pólos de emprego formal na cidade de São Paulo, conforme visto no mapa à página 149 , é parte importante do problema. A constituição do Complexo de Cidade Tiradentes como espaço monofuncional agrava esse quadro pelo baixíssimo nível de empregos formais gerados no distrito: em 1999, havia apenas 459 empregos formais em Cidade Tiradentes, oferecidos em parcos 58 estabelecimentos, sendo que $79 \%$ destes empregos eram ofertados no setor de comércio e serviços. Nesse ano, essa quantidade de empregos representava apenas $0,03 \%$ do total de empregos do município ${ }^{84}$.

Em 2002 esse quadro havia melhorado um pouco, quando o conjunto contava já com 6.195 empregos formais. Destes, 85\% eram oferecidos nos setores de comércio e serviços (5.298 empregos formais). Essa quantidade representava, nesse ano, 0,19\% dos empregos com carteira assinada da cidade de São Paulo, enquanto sua população era estimada em cerca de $1,82 \%$ do total do município: 192.895 residentes num universo de 10.617.943 habitantes estimados para o ano de $2002^{85}$.

\footnotetext{
${ }^{81}$ Eram consideradas pobres as pessoas com rendimento mensal de até 0,5 salário mínimo, e indigentes aqueles com renda igual ou inferior a um quarto de salário mínimo. Cf. SÂO PAULO (cidade). Secretaria Municipal de Trabalho. Atlas do Trabalho e Desenvolvimento da Cidade de São Paulo. São Paulo: PMSP/SMT, 2007, p. 131. Acessado e baixado em 22 de novembro de 2008 do site "http://portal.prefeitura.sp.gov.br/secretarias/trabalho/atlasmunicipal/relatorios/0001" da Secretaria Municipal de Trabalho.

${ }^{82}$ Cf. SÂO PAULO (cidade). Secretaria Municipal de Trabalho. Op. Cit., 2007, p. 144.

${ }^{83}$ Cf. SÂO PAULO (cidade). Secretaria Municipal de Trabalho. Op. Cit., 2007, p. 107.

84 SÂO PAULO (cidade). Secretaria Municipal de Planejamento - SEMPLA. Planos Regionais Estratégicos - Subprefeitura Cidade Tiradentes. São Paulo: PMSP/SEMPLA, 2004, p. 13.

85 Cf. SEADE - Fundação Sistema Estadual de Análise de Dados. Emprego Formal, por Setor de Atividade, segundo Subprefeituras e Distritos - Município de São Paulo 2002. Acessado e baixado do site http://www.seade.gov.br/produtos/msp/index.php?tip=met4\&opt=s\&tema=EMP\&subtema=4 em 27 de novembro de 2008.
} 


\section{Distrito de Cidade Tiradentes}

Imagem de satélite - 2007

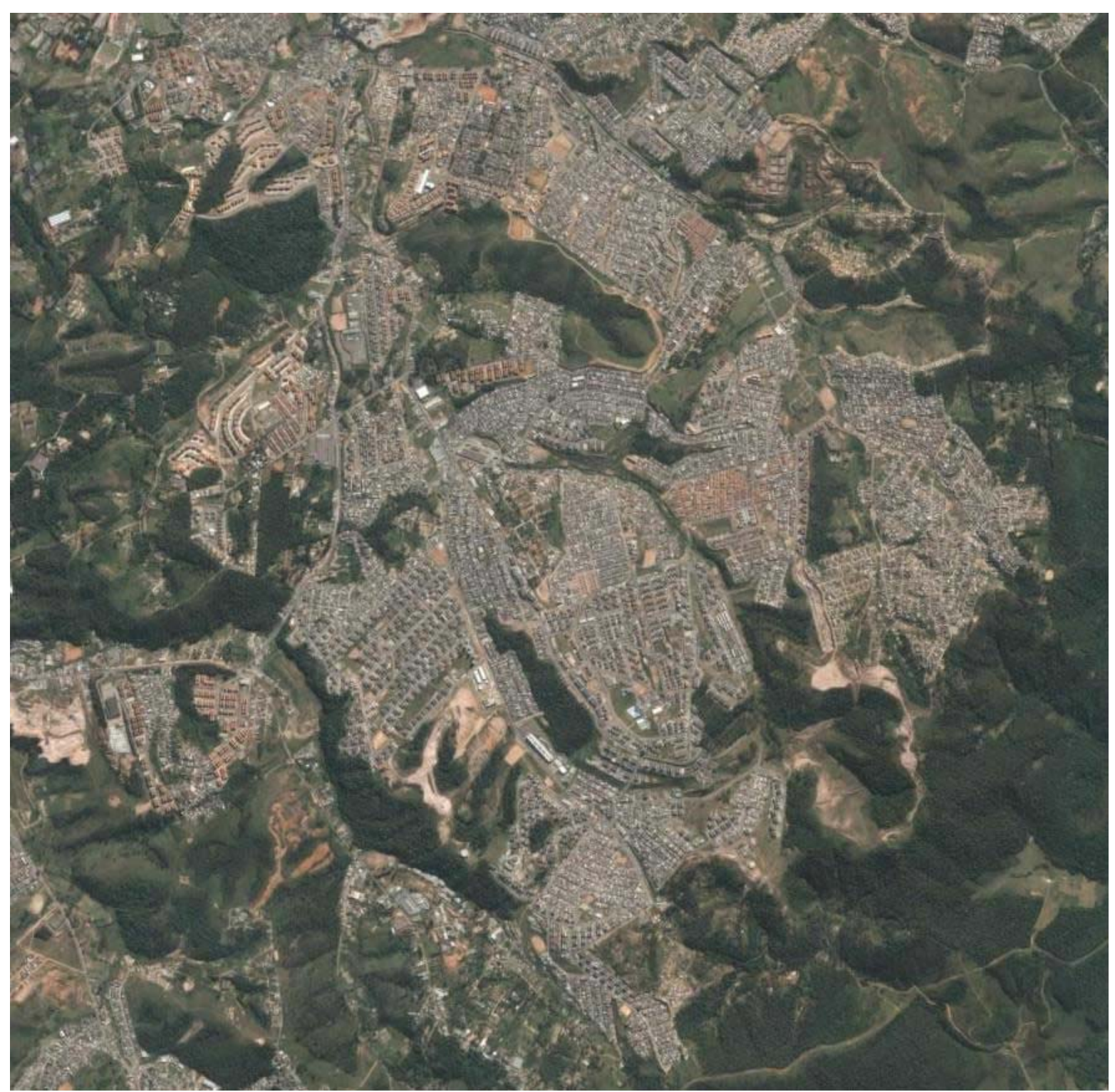

Fonte: Imagem acessada e baixada do Google Earth em 01 de dezembro de 2008.

Desse modo o distrito - três quartos dele produzido diretamente pelo poder público e o restante dos moradores para lá induzidos por essa mesma ação estatal agrega a uma baixíssima acessibilidade aos empregos e amenidades da cidade consolidada, a uma escassa oferta de equipamentos e serviços - públicos e particulares -, uma reduzidíssima oferta de empregos locais, além de um alto nível de desemprego. Em Cidade Tiradentes, no começo dos anos 2000, não havia trabalho, não havia lazer, não havia serviços, e não se saía do distrito. 
Distrito de Cidade Tiradentes

Conjuntos implantados pela COHAB-SP

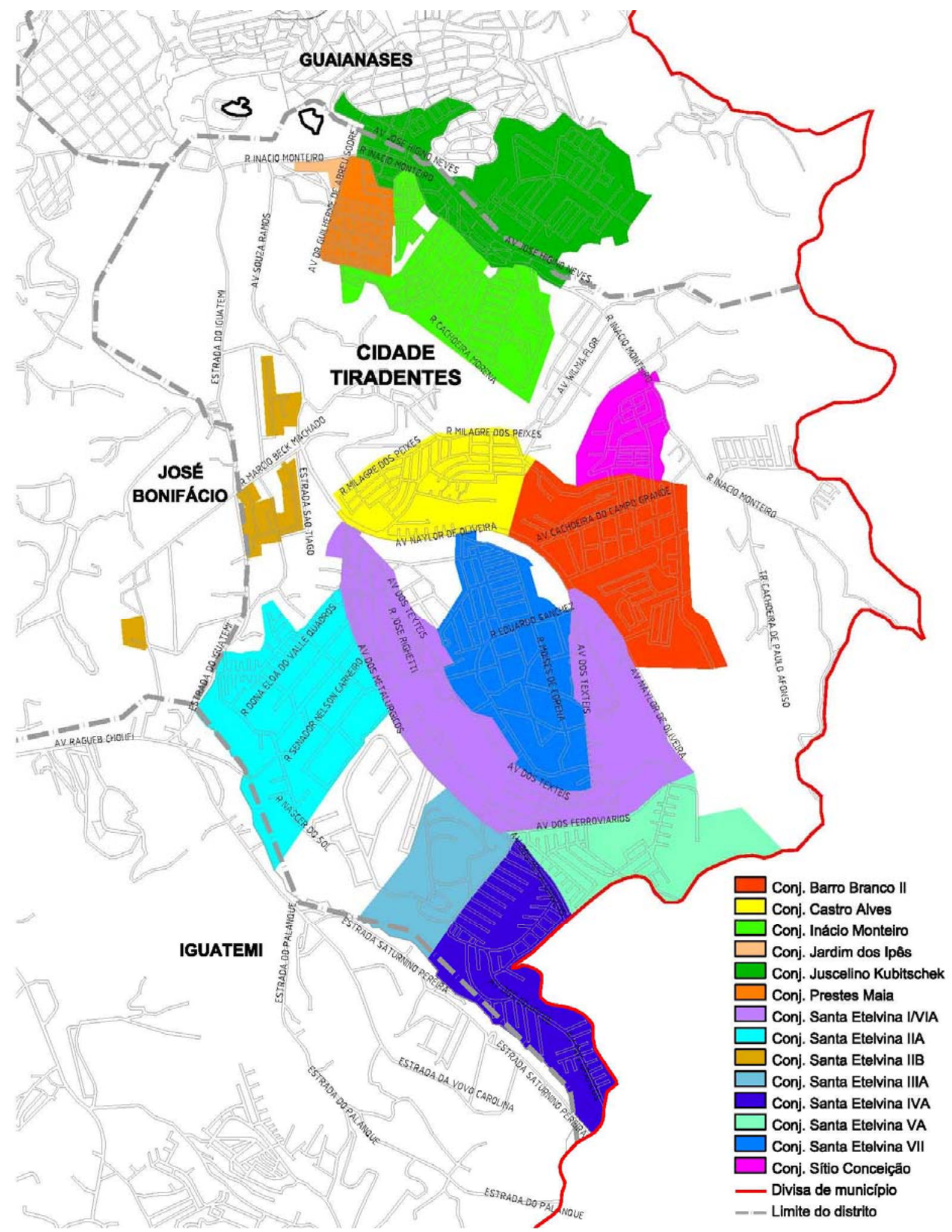

Fonte: SLOMIANSKY, Adriana Paula. Op. Cit., 2002.

Elaboração: Estevam Otero, sobre base CESAD-FAUUSP. MSPQ - Mapa Vetorial de Quadras Município de São Paulo. São Paulo, CESAD-FAUUSP, 2004. 
Internamente ao complexo a COHAB-SP edificou 20 centros comerciais, que agrupam 160 lojas de tamanho médio, cuja locação é efetuada por meio de licitação pública. Estes se encontram distribuídos de modo bastante desigual entre os diversos conjuntos, estando presentes em apenas sete deles, ao que se soma o fato de que $40 \%$ dos centros comerciais - oito no total - foram edificados no Conjunto Santa Etelvina $I / \mathrm{VIA}{ }^{86}$. Evidentemente, essa oferta de pontos comerciais, dentro de um universo de mais de 42 mil unidades habitacionais, revela-se insuficiente. Além disso, a extrema burocracia existente para se efetivar a locação de um ponto comercial (bem como os custos mais elevados que a opção pela legalidade implicam) da COHAB-SP acabam por, de certa forma, incentivar a irregularidade.

Assim,

a distribuição heterogênea dos centros comerciais pelo Complexo é uma variável que explica parcialmente a proliferação do comércio irregular, quer nos conjuntos que carecem totalmente de instalações regulares, quer naqueles em que as existentes atendem apenas parcialmente às necessidades da população ${ }^{87}$.
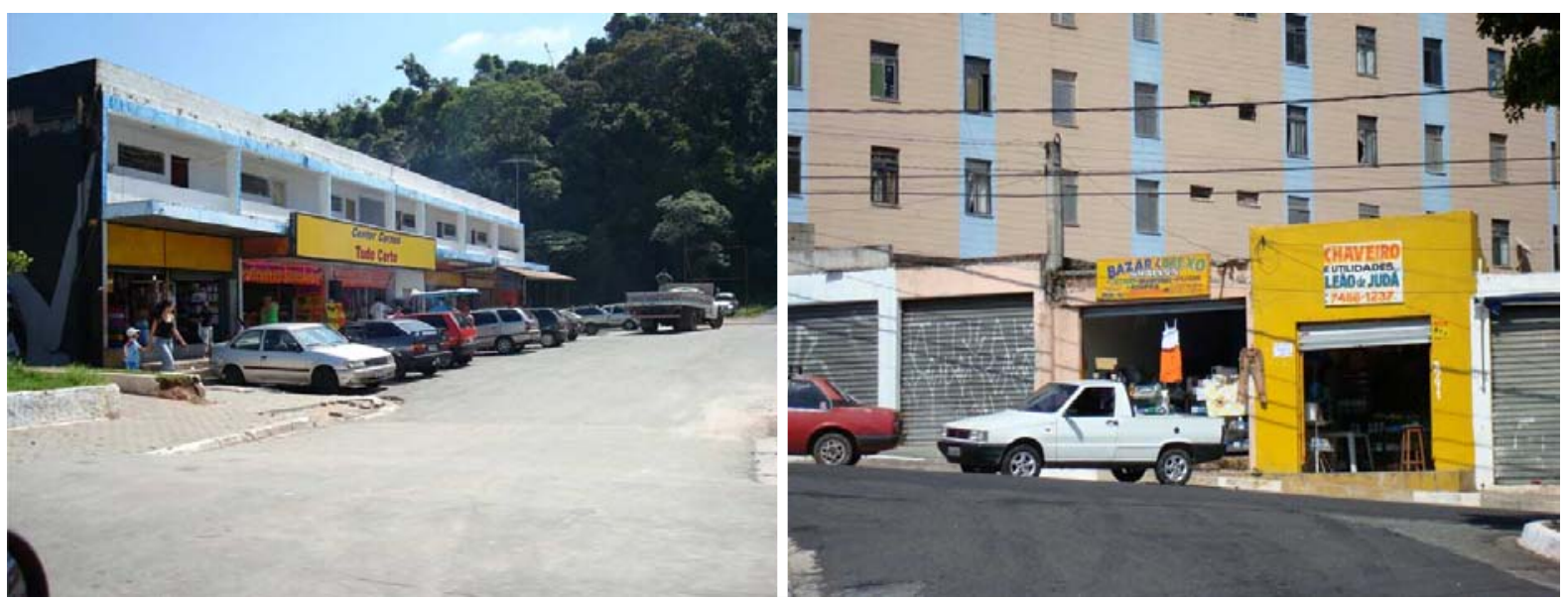

Na foto da esquerda, centro comercial da COHAB-SP, à avenida dos Metalúrgicos - Santa Etelvina I/VIA Foto: Daniel Yuhasz, 02/2008. Na foto da direita, estabelecimentos comerciais irregulares no muro de um condomínio de Santa Etelvina VII - Foto: Daniel Yuhasz, 02/2008.

A necessidade tanto de atividades geradoras de renda quanto a demanda por estabelecimentos comerciais e de serviços levou a uma resposta dos residentes que, como já se descreveu anteriormente, afrontava diretamente os princípios programáticos e projetuais dos grandes conjuntos de Cidade Tiradentes. De forma a suprir essas necessidades muitas das áreas comuns foram ocupadas e transformadas em pontos comerciais, a partir de aberturas nos muros dos condomínios. As propostas projetuais

\footnotetext{
${ }^{86}$ Cf. SLOMIANSKY, Adriana Paula. Op. Cit., 2002, p. 153.

${ }^{87}$ SLOMIANSKY, Adriana Paula. Op. Cit., 2002, p. 153.
} 
originais, com suas implantações de edifícios coletivos em meio a áreas livres sem uso definido e sem uma propriedade claramente caracterizada, acabaram subvertidas por essa apropriação privada das áreas comuns, e que ZANDONADE vai identificar como uma recomposição do tecido urbano da cidade tradicional, sobrepondo-se ao urbanismo de cunho modernista dos conjuntos ${ }^{88}$.

Além das áreas condominiais dos prédios, residências unifamiliares, implantadas sob a forma de casas-embrião, passaram a abrigar usos mistos, com a função residencial compartilhando o espaço com as atividades comerciais exercidas pelos moradores. Tanto quanto a forma anterior - cuja irregularidade é mais evidente - também no caso das unidades prontas executadas pela Companhia a mudança ou compartilhamento de usos constitui-se numa ilegalidade ${ }^{89}$. Apenas no caso de lotes urbanizados, com a edificação realizada inteiramente pelo proprietário, esta alteração de usos seria legalmente viável ${ }^{90}$. Da mesma forma, algumas áreas de propriedade pública fora das áreas condominiais também foram ocupadas, abrigando pequenas edificações de uso comercial.

Apesar de ser uma flagrante irregularidade a "diversificação" do uso do solo nesses conjuntos visava atender uma necessidade prática da população residente: essas ocupações de áreas comuns visavam suprir as demandas de seus moradores por elementos não atendidos nos programas dos edifícios, como garagens, ou estabelecendo meios de geração de renda e pólos de consumo. Quanto à ocupação das áreas condominiais e sua exploração por atividades comerciais, SLOMIANSKY chega a descrever um mecanismo de pagamento de uma parcela mensal aos condôminos pela utilização da área comum, como uma espécie de compensação ${ }^{91}$. Em nossas entrevistas realizadas em fevereiro de 2008 não identificamos esse tipo compensação; constatamos, isto sim, que atualmente esses "imóveis" integram uma dinâmica imobiliária capitalista de locação e venda de pontos comerciais na região.

Durante levantamento de campo realizado em 2008 pudemos entrevistar alguns comerciantes e prestadores de serviços estabelecidos nesses locais. A proprietária de um salão de cabeleireiro à avenida dos Têxteis afirmou alugar aquele ponto comercial aproximadamente $20 \mathrm{~m}^{2}$ - por $\mathrm{R} \$ 180,00$ mensais. Ela afirmou residir em Cidade Tiradentes,

\footnotetext{
${ }^{88}$ Cf. ZANDONADE, Patrícia. Op. Cit., 2008, p. 156.

89 Em visita de campo ao distrito em outubro de 2002, pesquisadores do LABHAB - Laboratório de Habitação e Assentamentos Humanos da FAUUSP e técnicos da COHAB-SP almoçamos em um restaurante que ocupava irregularmente (e de forma bastante improvisada) uma dessas casas-embrião em Santa Etelvina I/VIA.

${ }^{90}$ Cf. SLOMIANSKY, Adriana Paula. Op. Cit., 2002, p. 160.

${ }^{91}$ Cf. SLOMIANSKY, Adriana Paula. Op. Cit., 2002, p. 162.
} 
mas não naquele condomínio; assegurou, ainda, que a "proprietária" que Ihe alugava aquele imóvel detinha mais dois pontos comerciais no mesmo condomínio, desconhecendo qualquer forma de pagamento ao condomínio pela utilização das áreas comuns do mesmo.
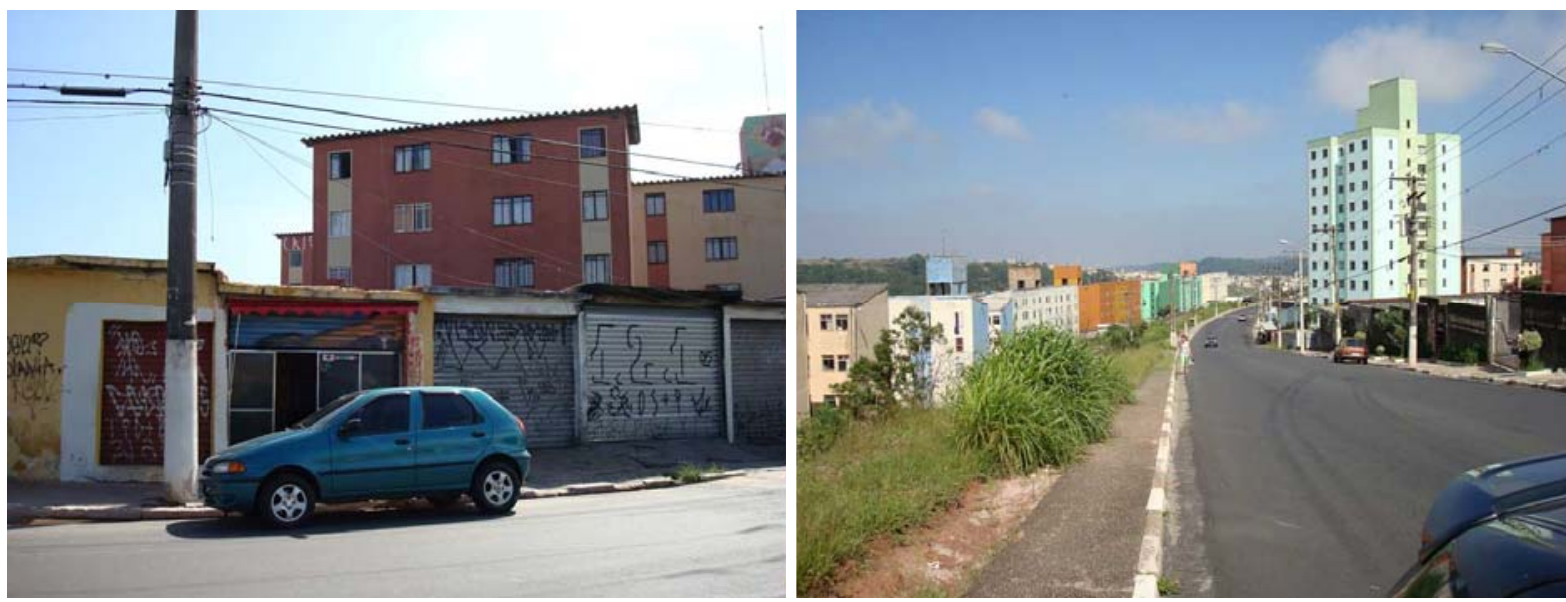

$\mathrm{Na}$ foto da esquerda, estabelecimentos comerciais irregulares no muro de um condomínio. Av. dos Têxteis Santa Etelvina I/VIA - Foto: Estevam Otero, 02/2008. Na foto da direita, vista da Av. dos Têxteis. À esquerda da imagem o conjunto Sta. Etelvina I/VIA - Foto: Daniel Yuhasz, 02/2008.

Ainda na avenida dos Têxteis localizamos outro pequeno conjunto de estabelecimentos comerciais, fora, porém, da área comum dos condomínios. Tratava-se de edificação térrea com diversas portas, claramente construída para abrigar estabelecimentos comerciais, em local caracterizado legalmente como área verde municipal. O proprietário de uma pequena loja de roupas nessa edificação afirmou ter comprado a loja no ano de 2007, quando de sua mudança para o distrito. Este comerciante também fez menção à melhoria das condições gerais de Cidade Tiradentes, informação recorrente nos contatos estabelecidos com outros moradores.
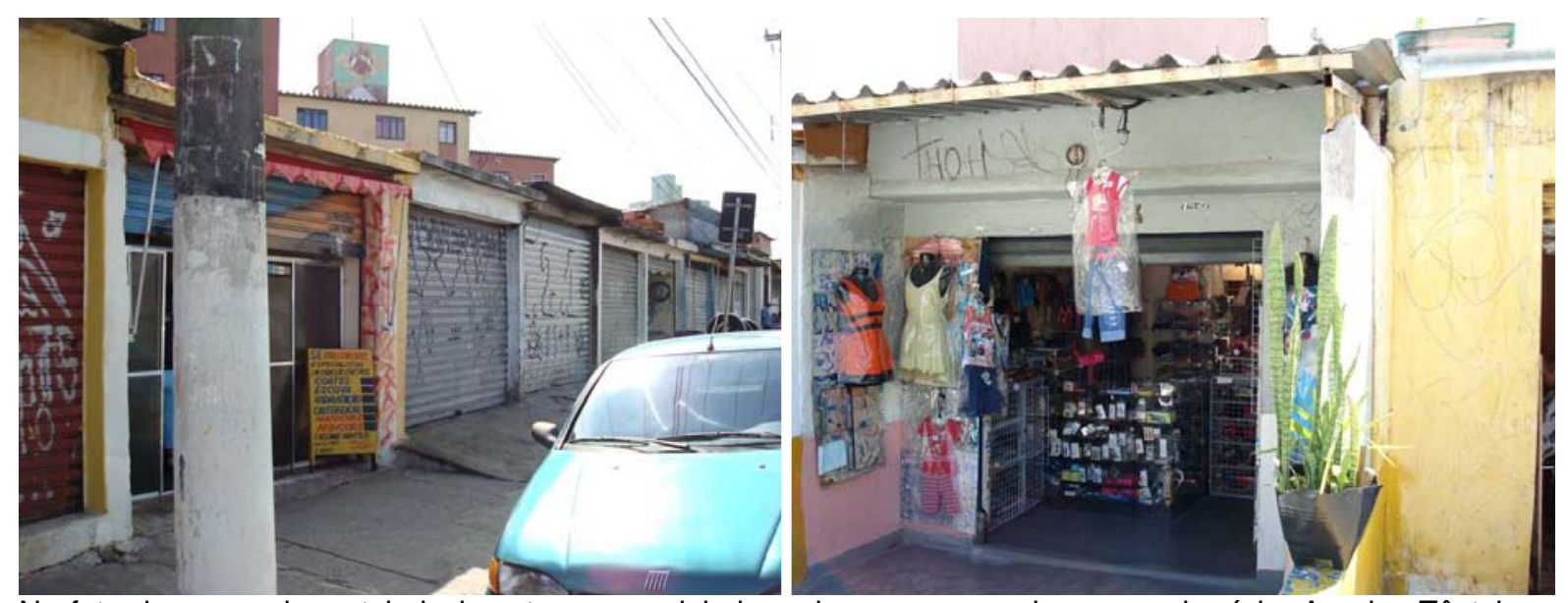

$\mathrm{Na}$ foto da esquerda, estabelecimentos comerciais irregulares no muro de um condomínio. Av. dos Têxteis Santa Etelvina I/VIA. Na foto da direita, comércio irregular ocupando área verde municipal. O "proprietário" afirma ter comprado o imóvel no ano de 2007 - Foto: Estevam Otero, 02/2008. 
No início dos anos 2000 Cidade Tiradentes acumulava um sem número de precariedades e carências, condicionando a vida de seus moradores e submetendo-os a um quadro de segregação, exclusão e alienação urbanas decorrentes diretamente da política habitacional implementada sob a égide do $\mathrm{BNH}$. A soma dessas precariedades, desemprego e isolamento, aliados à ausência do Estado - a despeito de sua presença opressiva refletida na morfologia urbana do distrito - produziram um quadro de tensão social e criminalidade que tornou Cidade Tiradentes um dos distritos mais violentos e com maior taxa de homicídios da cidade de São Paulo.

\section{Óbitos de Residentes Ocorridos por Faixa Etária OMS \\ Distrito: Cidade Tiradentes \\ Causas externas: Homicídio \\ Período: 1996-2007}

\begin{tabular}{|l|r|r|r|r|r|r|r|r|r|r|r|r|}
\hline Faixa Etária OMS & $\mathbf{1 9 9 6}$ & $\mathbf{1 9 9 7}$ & $\mathbf{1 9 9 8}$ & $\mathbf{1 9 9 9}$ & $\mathbf{2 0 0 0}$ & $\mathbf{2 0 0 1}$ & $\mathbf{2 0 0 2}$ & $\mathbf{2 0 0 3}$ & $\mathbf{2 0 0 4}$ & $\mathbf{2 0 0 5}$ & $\mathbf{2 0 0 6}$ & $\mathbf{2 0 0 7}$ \\
\hline menos de 1 ano & 0 & 0 & 0 & 0 & 0 & 0 & 1 & 0 & 0 & 0 & 0 & 0 \\
\hline 5 a 14 & 0 & 2 & 2 & 1 & 4 & 0 & 2 & 1 & 1 & 0 & 0 & 0 \\
\hline 15 a 24 & 33 & 44 & 51 & 63 & 93 & 76 & 47 & 56 & 29 & 17 & 10 & 7 \\
\hline 25 a 34 & 38 & 33 & 31 & 55 & 58 & 36 & 36 & 31 & 17 & 16 & 12 & 10 \\
\hline 35 a 44 & 14 & 13 & 20 & 22 & 26 & 18 & 15 & 20 & 11 & 10 & 1 & 5 \\
\hline 45 a 54 & 6 & 2 & 5 & 5 & 11 & 9 & 4 & 11 & 5 & 7 & 2 & 4 \\
\hline 55 a 64 & 0 & 1 & 1 & 2 & 3 & 0 & 0 & 0 & 1 & 0 & 0 & 0 \\
\hline 75 e mais & 0 & 0 & 0 & 1 & 0 & 0 & 0 & 0 & 0 & 0 & 0 & 0 \\
\hline TOTAL & $\mathbf{9 1}$ & $\mathbf{9 5}$ & $\mathbf{1 1 0}$ & $\mathbf{1 4 9}$ & $\mathbf{1 9 5}$ & $\mathbf{1 3 9}$ & $\mathbf{1 0 5}$ & $\mathbf{1 1 9}$ & $\mathbf{6 4}$ & $\mathbf{5 0}$ & $\mathbf{2 5}$ & $\mathbf{2 6}$ \\
\hline
\end{tabular}

Fonte: PRO-AIM / CEInfo - Secretaria Municipal de Saúde

Acessado em 13 de novembro de 2008 no site da Secretaria Municipal de Saúde: http://ww2.prefeitura.sp.gov.br/cgi/tabcgi.exe?secretarias/saude/TABNET/SIM/obito.def

Elaboração: Estevam Otero

O número de homicídios em Cidade Tiradentes vinha crescendo ao longo de toda a década de 1990, atingindo o ápice no ano 2000, quando foram registrados os assassinatos de 195 residentes no distrito. Nesse mesmo ano, Cidade Tiradentes registrou a segunda maior taxa bruta de homicídios dentre os distritos de São Paulo - 102,9 por 100.000 habitantes, atrás apenas de Parelheiros, com 106,6. A partir de então, passou-se a verificar uma forte tendência de queda do número de assassinatos, como se pode ver na tabela acima.

É difícil precisar as razões que levaram à redução acelerada do número de homicídios em Cidade Tiradentes. Entretanto, podemos traçar um paralelo entre essa tendência e uma inflexão nas políticas públicas implementadas a partir de 2001 no distrito, levadas a cabo pela nova administração municipal. A partir de então, diversos programas e ações foram realizados com o intuito de melhorar as condições sociais, ambientais e urbanísticas na região, com a execução de equipamentos e a implantação de serviços 
públicos, a implementação de programas de complementação de renda, de melhorias urbanísticas, dentre outros.

Nesse mesmo período foram constituídos dois programas municipais voltados à reabilitação de territórios marcados pela segregação socioespacial: o Viver Melhor e o Bairro Legal. Ambos com especificidades e diferenças em suas concepções, escopos e âmbitos de execução, mas cujas propostas objetivavam alterar a realidade socioespacial de Cidade Tiradentes.

O Viver Melhor consistia num programa da própria COHAB-SP voltado à superação do passivo que a Companhia reconhecia ter com os moradores de seus conjuntos, a partir da implantação de equipamentos públicos em áreas de sua propriedade. O piloto do programa foi realizado em Cidade Tiradentes, pelo próprio simbolismo do distrito no conjunto da produção da COHAB.

O Bairro Legal consistia num programa voltado a formatar ações de reabilitação urbana para os distritos mais violentos de São Paulo: Vila Brasilândia, Jardim Ângela e Cidade Tiradentes, procurando desenvolver intervenções urbanísticas e de gestão que tivessem impacto na redução da exclusão social e da violência nessas áreas. O referido programa não tinha por enfoque específico a requalificação de conjuntos habitacionais; entretanto, pelo fato de um dos distritos objeto do estudo se tratar de Cidade Tiradentes, o Plano de Ação desenvolvido pela USINA-Ctah para o distrito acaba por elencar uma série de ações destinadas, em última análise, à requalificação desse grande conjunto, enfrentando suas contradições. Este programa não chegou a ser implementado.

Dessa forma, ambos os programas, cada um a seu modo, objetivavam a intervenção e a qualificação do cotidiano dos moradores de Cidade Tiradentes, desenvolvendo algumas reflexões acerca da segregação imposta a essas populações e formas de enfrentá-la. No capítulo seguinte serão analisados o escopo e as propostas do programa Viver Melhor, coordenado e implementado pela COHAB-SP entre os anos de 2001 e 2004. 
CAPÍTULO 4

AS INICIATIVAS E OS PROGRAMAS

PÚBLICOS DE REABILITAÇÃO

DE CONJUNTOS HABITACIONAIS

EM SÃO PAULO 
Serão analisadas neste quarto capítulo as políticas levadas a cabo na Região Metropolitana de São Paulo com o objetivo de reabilitar os grandes conjuntos habitacionais promovidos pela COHAB-SP ao longo de sua história. Para tanto, procederemos a uma avaliação das distintas e seguidas políticas e programas implementados com o intuito declarado de melhorar as condições ambientais e urbanísticas desses espaços, visando minimizar as desigualdades socioterritoriais entre os conjuntos da Companhia e as áreas com as melhores condições sociais e de infra-estrutura da metrópole, procurando impactar positivamente a qualidade de vida de seus moradores.

Serão estudados aqui os primeiros e incipientes diagnósticos e propostas elaborados no interior da COHAB-SP durante a gestão municipal 1989-1992 (Administração Luiza Erundina), quando ainda não se pode identificar um conjunto de ações articulado e integrado objetivando a reabilitação dos grandes conjuntos, mas pela primeira vez é desenvolvido um diagnóstico acerca dos problemas ali verificados e se define a necessidade de intervenção nesse "passivo" produzido pela ação do poder público.

Analisaremos e avaliaremos, também, o primeiro programa estruturado especificamente para enfrentar esse "passivo" que condiciona a vida dos moradores dos conjuntos da COHAB-SP: o Programa Viver Melhor, destinado a "melhorar a qualidade de vida dessa população, por meio de intervenções que propiciem a qualificação urbana nos conjuntos e a sua inserção na cidade, promovendo a inclusão social"1. Este programa foi desenvolvido e implantado pela Companhia entre os anos de 2001 e 2004.

Para proceder a essa análise tomaremos como chave os princípios definidos por BLOS $^{2}$, em que a autora avalia a reabilitação dos grandes conjuntos na Europa a partir da capacidade dessas propostas em enfrentar três questões estruturais e complementares, tanto internamente aos mesmos como em sua relação com a cidade consolidada ${ }^{3}$ :

${ }^{1}$ COHAB-SP. Programa Viver Melhor. São Paulo: COHAB-SP/PMSP, s/d, mimeo. Material cedido ao autor pela ex-Coordenadora Técnica do Programa Viver Melhor (2001-2002), Margareth Matiko Uemura.

${ }^{2}$ Ver a já citada tese de doutorado de Dorotea Blos, em que a autora analisa os principais programas e projetos de reabilitação urbanística, ambiental e social implementados nos grandes conjuntos da Espanha e França entre as décadas de 1970 e 1990. BLOS, Dorotea. Los Polígonos de Vivienda Social: perspectivas hacia su recuperación en España, Francia y Brasil. Tese de doutorado apresentada à Escola Técnica Superior de Arquitectura de Barcelona / Universitat Politècnica de Catalunya. Barcelona: ETSAB/UPC, 1999.

${ }^{3}$ O termo "cidade consolidada" aqui é entendido na medida em que define o trecho da cidade habitado pelas camadas de mais alta renda, comportando a melhor e mais completa infra-estrutura urbana. $O$ termo está expresso no Plano Diretor Estratégico de São Paulo na definição da "Macroárea de Urbanização Consolidada". A Lei no 13.430, de 13 de setembro de 2002, em seu artigo 156 estabelece a definição dessa macroárea: 
- a integração física: representada pela ruptura do isolamento e insulamento tão característicos dessa forma urbana, envolvendo melhorias internas aos perímetros dos conjuntos e em sua relação com a cidade como um todo, relacionadas à qualificação urbanística interna e às condições de acessibilidade e mobilidade;

- a integração funcional: entendida como a descaracterização dessas áreas como cidades-dormitório, monofuncionais, de modo a produzir uma diversificação de usos e atividades que impliquem numa maior complexidade urbana, decorrendo em novas possibilidades de apropriação e numa nova dinâmica econômica, integrando-os ao circuito econômico da cidade à sua volta;

- e a integração social: representada pelo conjunto de medidas de qualificação social da população aí residente, rompendo com a condição de exclusão socioeconômica a que estes moradores se vêem submetidos, enfrentando a dimensão social dos problemas que atingem essas áreas de forma global ${ }^{4}$.

Com isso em vista, procuraremos analisar de que modo as ações e propostas implementadas pela COHAB-SP impactaram na redução da segregação socioespacial das populações residentes nos grandes conjuntos de São Paulo, em função da formulação de MARQUES acerca da possibilidade de redução das desigualdades socioespaciais na metrópole de São Paulo. Segundo ele isso seria possível por meio do investimento maciço em melhorias das condições urbanas das porções do território homogeneamente habitados por populações de baixa renda, de modo a reduzir o diferencial de infra-estrutura, equipamentos e serviços urbanos entre os diferentes pontos da cidade ${ }^{5}$.

Art. 156 - A Macroárea de Urbanização Consolidada, ocupada majoritariamente pela população de renda alta e média alta, é formada pelos bairros estritamente residenciais e pelas áreas que tem sofrido um forte processo de verticalização e adensamento construtivo, e, embora conte com excepcionais condições de urbanização e alta taxa de emprego, tem sofrido esvaziamento populacional e apresentado níveis elevados de saturação da malha viária.

$\S 1^{\circ}$ - A Macroárea de Urbanização Consolidada é formada pelos territórios delimitados pelos distritos de Alto de Pinheiros, Butantã, Campo Belo, Consolação, Itaim Bibi, Jardim Paulista, Lapa, Moema, Morumbi, Perdizes, Pinheiros, Santo Amaro, Tatuapé, Vila Andrade e Vila Mariana, com exceção das áreas localizadas nas Operações Urbanas, e pelas Zonas Estritamente Residenciais existentes e criadas por esta lei.

${ }^{4}$ Cf. BLOS, Dorotea. Op. Cit., 1999, p. 459-60.

${ }^{5}$ Cf. MARQUES, Eduardo. Op. Cit., 2005a, p. 50. 
Evidentemente não se tem a ilusão de que uma política pública com essas características bastaria para enfrentar o problema em tela, uma vez que os diferenciais de localização não são reproduzíveis, de forma que várias das questões que constrangem os moradores dos conjuntos a um cotidiano segregado e alienado - como visto no capítulo anterior - permaneceriam fora do alcance desse tipo de ação. Entretanto, é inegável que essas ações, ao garantirem acesso às amenidades e serviços da cidade legal e consolidada, produzem impactos altamente relevantes na qualidade de vida dos residentes, permitindo que estes atinjam um novo patamar de cidadania em que a luta pelo direito à cidade deixa de ser a luta pela sobrevivência imediata e passa a ser a luta por sua inserção digna na sociedade.

\subsection{Antecedentes da reabilitação de conjuntos habitacionais em São Paulo}

A primeira vez em que a qualidade ambiental e urbanística presente nos conjuntos habitacionais da COHAB-SP tornou-se objeto de uma avaliação crítica pode ser encontrada na administração municipal 1989-1992 (Administração Luiza Erundina) quando, pela primeira vez, dentro do poder público, se questiona o produto de décadas de busca pela maximização de unidades ao menor preço (e a qualquer custo). Nesse momento procedia-se à entrega do maior complexo de conjuntos de São Paulo e da América Latina Cidade Tiradentes - cujo impacto e precariedade certamente contribuíram para essa inflexão no sentido de questionar a própria lógica da produção da Companhia.

Essa primeira reflexão, contudo, não levou à instituição de um programa especificamente voltado à reabilitação dos grandes conjuntos, não resultando na formulação de propostas articuladas e integradas destinadas a elevar a qualidade ambiental e urbanística desses locais. Tratou-se, na verdade, de um primeiro diagnóstico empírico e não formalizado - acerca das precariedades e incongruências do modelo.

Na Companhia a administração 1989-92 foi marcada pela execução e entrega das obras já em andamento desde as gestões anteriores. A produção de novas unidades esteve a cargo de HABI - Superintendência de Habitação Popular da SEHAB - Secretaria de Habitação e Desenvolvimento Urbano. Nesse momento, centralizadas em HABI, foram implementadas propostas arquitetônicas bastante significativas do ponto de vista da qualidade dos projetos, claramente como resultado da avaliação do fracasso do modelo anterior de produção de grandes conjuntos ${ }^{6}$.

\footnotetext{
${ }^{6}$ Para maiores informações sobre a produção habitacional realizada por HABI no período ver ANDRADE, Carlos R. M. de, BONDUKI, Nabil e ROSSETTO, Rossella (Org.). Arquitetura e Habitação Social em São Paulo, 1989-1992. São Paulo: USP/EESC, 1993.
} 
Ficou a cargo da Gerência de Projetos da COHAB-SP o desenvolvimento de ações com vistas à melhoria das condições de vida nos conjuntos habitacionais. $O$ arquiteto Vladimir Bartalini, Gerente de Projetos da Companhia entre os anos de 1989 e 1992, relatou que naquele momento as propostas de melhorias nos conjuntos previam, fundamentalmente, a intervenção nas implantações dos edifícios, com vistas à requalificação dos espaços residuais resultante da edificação de tipologias padronizadas e sem preocupação com o espaço urbano resultante ${ }^{7}$.

Uma dessas intervenções foi realizada durante as obras de execução do conjunto habitacional Jardim Antártica, em que as implantações dos edifícios foram alteradas no início das obras para melhorar sua condição urbanística. Ainda segundo o arquiteto Vladimir Bartalini a Superintendência de Projetos da COHAB-SP era refratária a essas revisões; da mesma forma, a Caixa Econômica Federal - sucessora do BNH no financiamento habitacional - também era resistente à adoção de tipologias nãoconvencionais alternativas às tipologias-padrão $H$.

A arquiteta Margareth Matiko Uemura ${ }^{8}$ foi Gerente de Projetos da COHAB-SP para as regiões Sul e Sudeste de São Paulo nessa mesma administração municipal. Ela também relata essas primeiras iniciativas, enfatizando que a preocupação com a baixa qualidade dos empreendimentos da Companhia já era corrente desde fins dos anos 1980. Entretanto, essas incipientes iniciativas não foram sistemáticas, nem compreenderam um conjunto articulado de propostas, representando ações de pequeno porte e pontuais.

Margareth Uemura ressaltou, ainda, que uma das ações desse período tinha por objeto a questão do enfrentamento das invasões de áreas originalmente destinadas a equipamentos públicos ou adensamentos futuros dentro dos conjuntos, acarretando num processo de "favelização" a partir de suas áreas livres.

A importância desse momento reside mais no significado dessa mudança de enfoque da produção - da unidade habitacional para o espaço urbano - que na produção de resultados mensuráveis sob essa nova abordagem. Até porque essas ações tiveram alcance ínfimo frente ao problema que se apresentava.

\footnotetext{
${ }^{7}$ Essas informações foram transmitidas ao autor pelo Prof. Dr. Vladimir Bartalini em entrevista realizada em 17 de abril de 2008.

8 Em entrevista realizada pelo autor em 30 de março de 2007. Margareth Uemura, durante a administração municipal 2001-2004, foi uma das estruturadoras do Programa Viver Melhor e Coordenadora Técnica do mesmo entre 2001 e 2002.
} 


\subsection{Programas públicos de reabilitação de conjuntos habitacionais em São Paulo: o Viver Melhor}

O primeiro programa público cujo objetivo manifesto era a reabilitação urbanística, ambiental e social de conjuntos habitacionais na cidade de São Paulo foi desenvolvido pela COHAB-SP ao longo da administração 2001-2004 (Administração Marta Suplicy) sob o nome "Viver Melhor".

Este programa propunha uma série de ações integradas e de enfoque amplo, muitas vezes implementadas sob a forma de parcerias com outros órgãos públicos e/ou entidades civis, com o objetivo declarado de promover a "inserção urbana", a "melhoria da qualidade de vida" e a "inclusão dos moradores dos Conjuntos Habitacionais da Cohab SP e entornos" ${ }^{\prime \prime}$.

Dentre os objetivos específicos do programa podiam ser elencados os seguintes pontos:

- Destinação das áreas livres, e otimização do uso dos núcleos comerciais e centros comunitários;

- Ampliação do universo de famílias atendidas, estimulando programas e projetos de entidades e associações, conforme a necessidade local;

- Fomento ou participação em ações que implementem equipamentos para a geração de renda, lazer, cultura, educação, saúde, esporte e assistência social;

- Incentivo ou cooperação em ações do planejamento urbano e ambiental;

- Ações de regularização de áreas e de conjuntos habitacionais;

- Iniciativas que contribuam para regularização da situação contratual dos moradores. ${ }^{10}$

Apesar desses objetivos gerais e específicos claros e concisos $^{11}$, é importante ressaltar que o programa Viver Melhor não nasceu completamente estruturado e com todos os seus propósitos e meios plenamente estabelecidos. Segundo Altemir Almeida esse conjunto de ações que resultará no programa teve como ponto de partida o entendimento ainda que difuso - de que a Companhia tinha uma dívida para com os moradores dos

\footnotetext{
${ }^{9}$ ALMEIDA, Altemir A. de e FRANCO, André F. (Coord.). Programa Viver Melhor. São Paulo: COHABSP/PMSP, 2004, p. 1.

${ }^{10}$ ALMEIDA, Altemir A. de e FRANCO, André F. (Coord.). Op. Cit., 2004, p. 7.

${ }^{11}$ Estes objetivos aqui elencados foram extraídos da publicação editada pela COHAB-SP em junho de 2004, no fim da gestão, portanto. O material em questão apresenta uma característica de balanço dos esforços já realizados dentro do programa, representando mais uma racionalização post factum. Conforme relato de profissionais que atuaram no Viver Melhor, o programa foi sendo constituído e estruturado ao longo de sua implementação.
} 
conjuntos habitacionais por ela implantados, decorrência da forma como a baixa qualidade de sua produção impactava e condicionava a vida de seus habitantes. Desde o início daquela administração se tinha a "percepção de que seria necessário fazer o resgate dessa dívida com a população moradora"12.

No início de 2001 um grupo da COHAB-SP realizou visita oficial à França com o objetivo de conhecer a experiência francesa de reabilitação dos grandes conjuntos daquele país, a fim de obter subsídios à formulação de propostas para questão semelhante na cidade de São Paulo. Essa comitiva tomou contato com as intervenções recém-realizadas em conjuntos na região de Saint-Denis ${ }^{13}$.

Segundo a técnica da COHAB-SP Renata Milanesi ${ }^{14}$, os primeiro passos para a estruturação das ações de reabilitação nos conjuntos foi dado logo no início de 2001, quando foi formado um Grupo de Trabalho composto por técnicos das distintas diretorias da Companhia, com o objetivo de elaborar um diagnóstico da situação dos conjuntos e propor diretrizes para a requalificação dos mesmos, enfocando o combate à exclusão social. Nesse momento essas ações eram coordenadas pela vice-presidência da COHAB, ocupada pela geógrafa Arlete Moysés Almeida ${ }^{15}$.

A Companhia reconhecia as carências sociais e ambientais presentes em seus conjuntos habitacionais, representada pela inexistência ou pela baixa qualidade dos equipamentos e serviços públicos nesses espaços. Como decorrência desse reconhecimento buscou-se equipar os conjuntos que apresentavam as maiores carências, procurando, assim, diminuir as desigualdades espaciais no tocante à infra-estrutura dos conjuntos em relação à cidade consolidada.

A partir dessa constatação a Diretoria de Patrimônio levantou os imóveis vazios de propriedade da Companhia (caracterizados como Área Institucional ou como Área Reservada para COHAB) nos conjuntos habitacionais - e que apresentassem viabilidade para a implantação de equipamentos - e passou a oferecê-los aos diversos órgãos e secretarias municipais em busca de interessados em implantá-los. Essa oferta de áreas

\footnotetext{
${ }^{12}$ Altemir Almeida foi Diretor de Patrimônio da COHAB-SP entre 2001 e 2004. Entrevista realizada pelo autor em 3 de setembro de 2008.

13 Informação fornecida por Suely Muniz, Diretora Financeira da COHAB-SP entre 2001 e 2004 e Presidente da Companhia em 2004, e que foi parte do grupo que visitou os conjuntos franceses. Entrevista realizada pelo autor em 28 de março de 2008. Esta região da periferia de Paris foi o epicentro dos choques entre moradores dos grandes conjuntos e as forças de segurança francesa em outubro de 2005, quando os distúrbios se originaram em Clichy-sous-Bois.

14 A arquiteta Renata Milanesi é técnica da COHAB-SP e integrou a primeira equipe do programa. Entrevista realizada pelo autor em 29 de dezembro de 2008.

${ }^{15}$ Não foi possível ter acesso a esse diagnóstico.
} 
despertou grande (e inesperado) interesse dos órgãos da Prefeitura. O Programa Viver Melhor foi estruturado após essa primeira experiência e tendo por pontos de partida que:

1. a COHAB tinha inúmeros próprios sem destinação dentro dos conjuntos;

2. os conjuntos apresentavam grave déficit de equipamentos e serviços públicos e;

3. diversos órgãos do poder público e, eventualmente, associações da sociedade civil, tinham grande interesse por áreas para a implantação de equipamentos e projetos.

A partir disso o programa começou a ser desenhado e estruturado internamente à Diretoria de Patrimônio da Companhia. Estabeleceu-se uma Coordenação Técnica, cuja função primordial dizia respeito à articulação entre a Companhia e os órgãos e instituições parceiros, definindo e viabilizando a ocupação das áreas da COHAB-SP ${ }^{16 .}$

As demandas por ações nos conjuntos eram definidas em função do que se identificava como "passivos" presentes nos mesmos, decorrentes de sua concepção, projeto e implantação, entre outros. Mesmo nos conjuntos já regularizados - nos quais, portanto, a COHAB-SP não teria quaisquer obrigações - tinha-se a percepção de que havia um "passivo" a ser enfrentado.

Para estabelecer as prioridades de intervenção necessárias aos conjuntos desenvolveu-se internamente à Companhia uma avaliação das condições presentes em cada um deles. Segundo Altemir Almeida "as demandas de uso e ocupação das áreas eram estabelecidas pela equipe social da COHAB-SP, que realizava um diagnóstico relativamente aos equipamentos presentes no conjunto e em seu entorno". Dessa forma os usos a serem implantados nos conjuntos habitacionais eram definidos originalmente pela COHAB em função da demanda por ela verificada. A partir da constatação dessas carências - em equipamentos de saúde, educação, cultura etc - a Companhia buscava o órgão ou instituição responsável por esse atendimento, ofertando a área para a instalação do equipamento demandado, identificando o possível parceiro com interesse e/ou possibilidade em implantá-lo.

O programa teve início com a execução de um projeto-piloto no conjunto Santa Etelvina IIIA, definido em função de apresentar "indicadores socioeconômicos críticos", e cujo objetivo era a "reversão do quadro de abandono e exclusão social"17 dessa área.

\footnotetext{
${ }^{16}$ A Coordenação Técnica do programa esteve a cargo, primeiramente, da arquiteta Margareth Matiko Uemura, entre os anos de 2001 e 2002. Entre 2002 e 2004 a Coordenação Técnica do Viver Melhor foi assumida pelo arquiteto André Folganes Franco.

${ }^{17}$ ALMEIDA, Altemir A. de e FRANCO, André F. (Coord.). Op. Cit., 2004, p. 8.
} 
Almeida ressalta, também, o simbolismo do complexo de cidade Tiradentes para a Companhia e para a administração municipa $\left.\right|^{18}$. Desse modo, a definição de se começar por lá teria sido natural e emblemática.

Em 2001, a Praça Profeta Jeremias, local de implantação do projeto-piloto, apresentava-se como único espaço de lazer de Santa Etelvina IIIA ${ }^{19}$, não passando de um grande terreno baldio de terra batida, em meio a 2.080 apartamentos, só neste setor. No perímetro da praça encontrava-se um núcleo comercial subutilizado da Companhia, em cujos fundos eram executados crimes e desovas de cadáveres ${ }^{20}$.

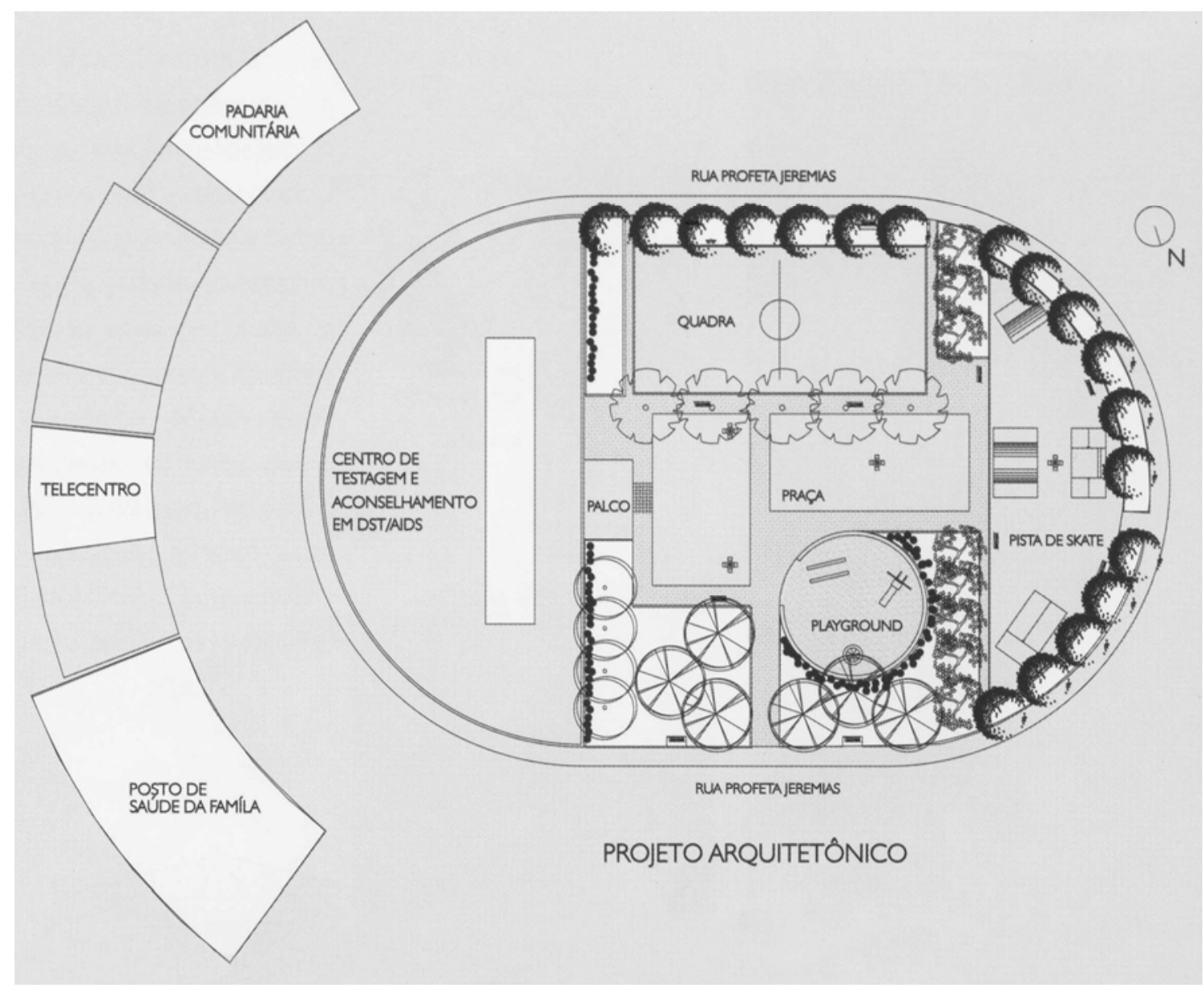

Projeto-piloto do Programa Viver Melhor, com a execução de reforma do núcleo comercial e da praça Profeta Jeremias, no conjunto Santa Etelvina IIIA in ALMEIDA, Altemir A. de e FRANCO, André F. (Coord.). Op. Cit., 2004 , p. 11.

A partir dessa realidade a intervenção executada pelo projeto-piloto consistiu na reforma da praça e do núcleo comercial, ocupando os boxes vazios com equipamentos e

\footnotetext{
${ }^{18}$ Havia acabado de ser criada, naquele momento, a subprefeitura de Cidade Tiradentes.

19 Ainda que 36,8\% da área do conjunto estivesse caracterizada, legalmente, como "área verde". Cf. SLOMIANSKY, Adriana Paula. Op. Cit., 2002.

${ }^{20}$ Conforme relatado por representante da COHAB-SP em visita de campo ao local em 30 de outubro de 2002.
} 
serviços públicos. Foram instalados aí um PSF - Posto de Saúde da Família, um Telecentro $^{21}$, uma padaria comunitária (denominada Café Cohab), e o CTA/DST-AIDS Centro de Testagem e Aconselhamento em Doenças Sexualmente Transmissíveis, bem como as demais lojas e salas comerciais passaram a ser ocupadas.

Segundo Altemir Almeida,

os primeiros Telecentros foram todos implantados nos conjuntos da COHAB, dentro do Programa Viver Melhor, numa parceria com a Secretaria de Comunicação. Dessa forma, o Viver Melhor foi importante na medida em que viabilizou a própria implementação inicial dos Telecentros ${ }^{22}$.

O arquiteto Daniel Amor, assessor da Diretoria de Patrimônio da COHAB-SP na gestão 2001-2004, descreve as ações implementadas pelo projeto-piloto:

Criamos então um programa para levar 'qualidade de vida' aos conjuntos, limpando e reformando praças, edifícios por nós controlados, etc. Também, como disse, buscamos levar os serviços de diversas secretarias a essa população. Fizemos um trabalho piloto em Santa Etelvina 3A, em Cidade Tiradentes. Recuperamos o centro comercial, que estava degradado, pichado, era utilizado para o consumo de drogas, ao lado havia um desmanche de automóveis. Reformamos o centro, e junto com a Secretaria de Comunicações, instalamos aí um Telecentro, o primeiro da capital, seis meses antes do segundo, que foi instalado na Brasilândia. Isso faz parte de um programa de inclusão da cidadania, pois hoje, para muitos empregos, é necessário que se saiba o mínimo de informática. Os computadores são utilizados para ensinar os programas básicos para os jovens. E para cuidar desse patrimônio, temos a Guarda Municipal cuidando da segurança por 24 horas, o que também contribui para a segurança do lugar. Para você ter uma idéia, no primeiro ano, de nove Telecentros instalados, sete estavam em Cohabs. Hoje são 15 em Cohabs num universo de 60 na cidade inteira. A proporção caiu, mas fomos pioneiros nisso. Também no Santa Etelvina 3A fizemos uma parceria com a Secretaria da Saúde e o Hospital Santa Marcelina, para a instalação de um Posto de Saúde da Família, no mesmo local do Telecentro. Foi também instalada, a partir de uma parceria com uma igreja alemã, uma Padaria Comunitária, que além de oferecer os cursos de panificação, vende o pão mais barato, e no horário entre as cinco e meia e sete da manhã, oferece gratuitamente um café da manhã (pão com manteiga e café com leite), para as pessoas que vão pegar as conduções em frente, já que essa gente passa cerca de duas horas no trânsito para ir trabalhar. Também cuidamos da questão da iluminação e do asfalto, e conseguimos estabelecer um posto avançado da Coordenadoria da Mulher aí. Dessa forma, buscamos melhorar a vida das pessoas e também cuidar da manutenção dos equipamentos instalados nas Cohabs $^{23}$.

Assim, o Viver Melhor possibilitou a viabilização de outros programas da administração municipal, ao disponibilizar alguns dos elementos fundamentais para a

\footnotetext{
${ }^{21}$ Telecentro foi um projeto implementado pela Prefeitura de São Paulo a partir de 2001, em que se disponibilizava instalações e equipamentos para acesso gratuito à internet e cursos de informática.

${ }^{22}$ Altemir Almeida. Entrevista...

${ }^{23}$ BOTELHO, Adriano. O financiamento e a financeirização do setor imobiliário: uma análise da produção do espaço e da segregação sócio-espacial através do estudo do mercado da moradia na cidade de São Paulo. Tese de doutorado apresentada à FFLCH. São Paulo: FFLCH, 2005, p. 260-1.
} 
realização de políticas públicas: áreas urbanizadas sem custo para a Prefeitura, e um diagnóstico prévio da demanda. Desse modo, tanto os primeiros Telecentros quanto os primeiros CEUs - Centros Educacionais Unificados da cidade de São Paulo foram implantados dentro de conjuntos habitacionais, em edificações ou terrenos viabilizados pelo programa ${ }^{24}$. Isto também é verdade em relação ao Hospital de Cidade Tiradentes, igualmente viabilizado numa área da Companhia.
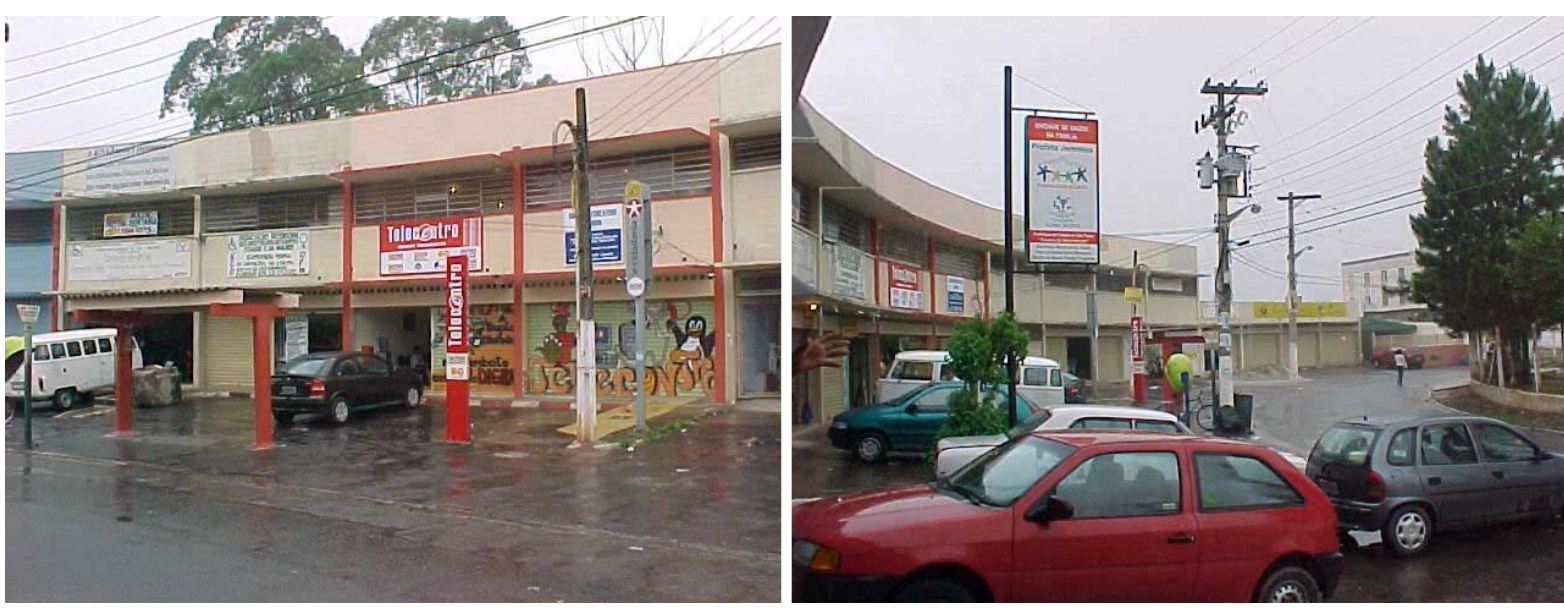

Projeto-piloto do Programa Viver Melhor no conjunto Santa Etelvina IIIA. Núcleo comercial reformado e adaptado para a implantação de Telecentro (foto da esquerda), posto do PSF - Programa de Saúde da Família e Café Cohab (foto da direita). Foto: Estevam Otero, outubro de 2002.

Foram implantados 23 Telecentros pelo Viver Melhor, em 17 conjuntos habitacionais. Além desses, uma série de equipamentos e serviços foram implementados sob a forma de parcerias entre a COHAB-SP e órgãos e secretarias do poder público, conforme se vê na tabela à página seguinte.
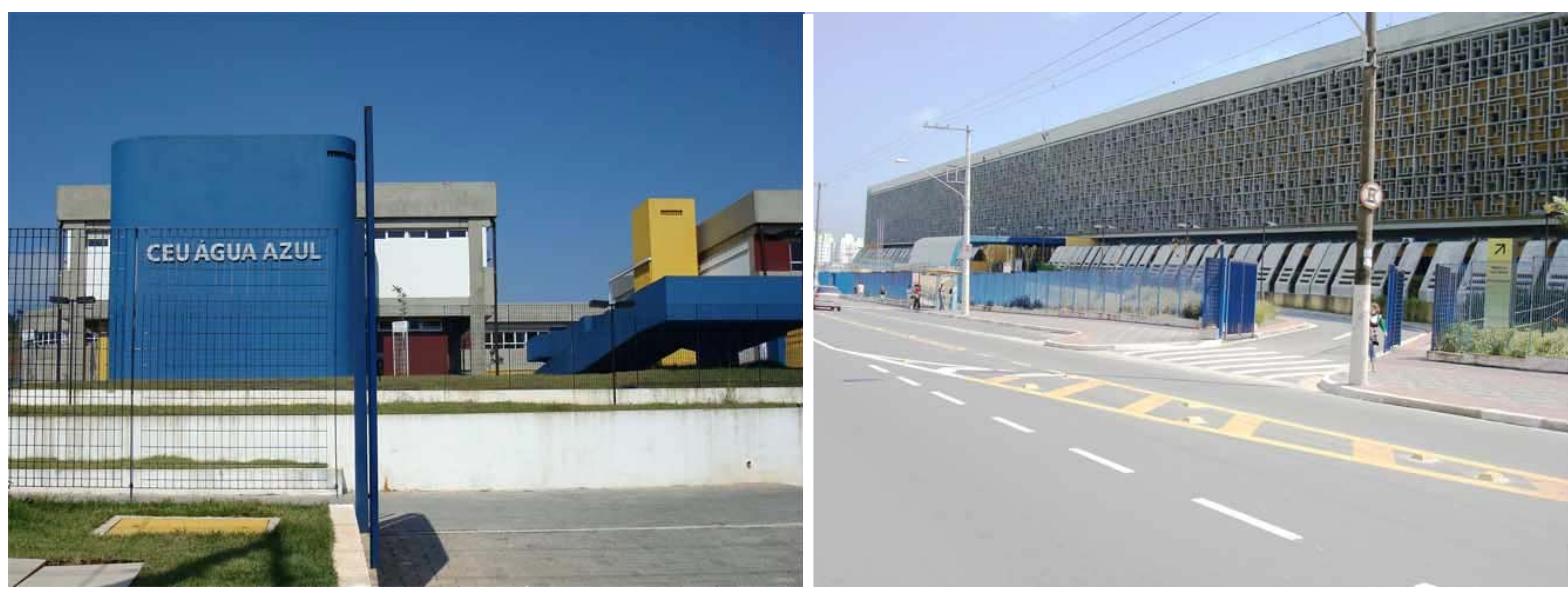

CEU Água Azul, implantado na av. dos Metalúrgicos em área disponibilizada pela COHAB-SP pelo programa, no conjunto Santa Etelvina IIIA, e inaugurado em outubro de 2007 (à esquerda). Hospital Cidade Tiradentes, também na av. dos Metalúrgicos, Santa Etelvina I/VIA (à direita). Foto: Daniel Yuhasz, fevereiro de 2008.

${ }^{24}$ Margareth Matiko Uemura. Entrevista... 


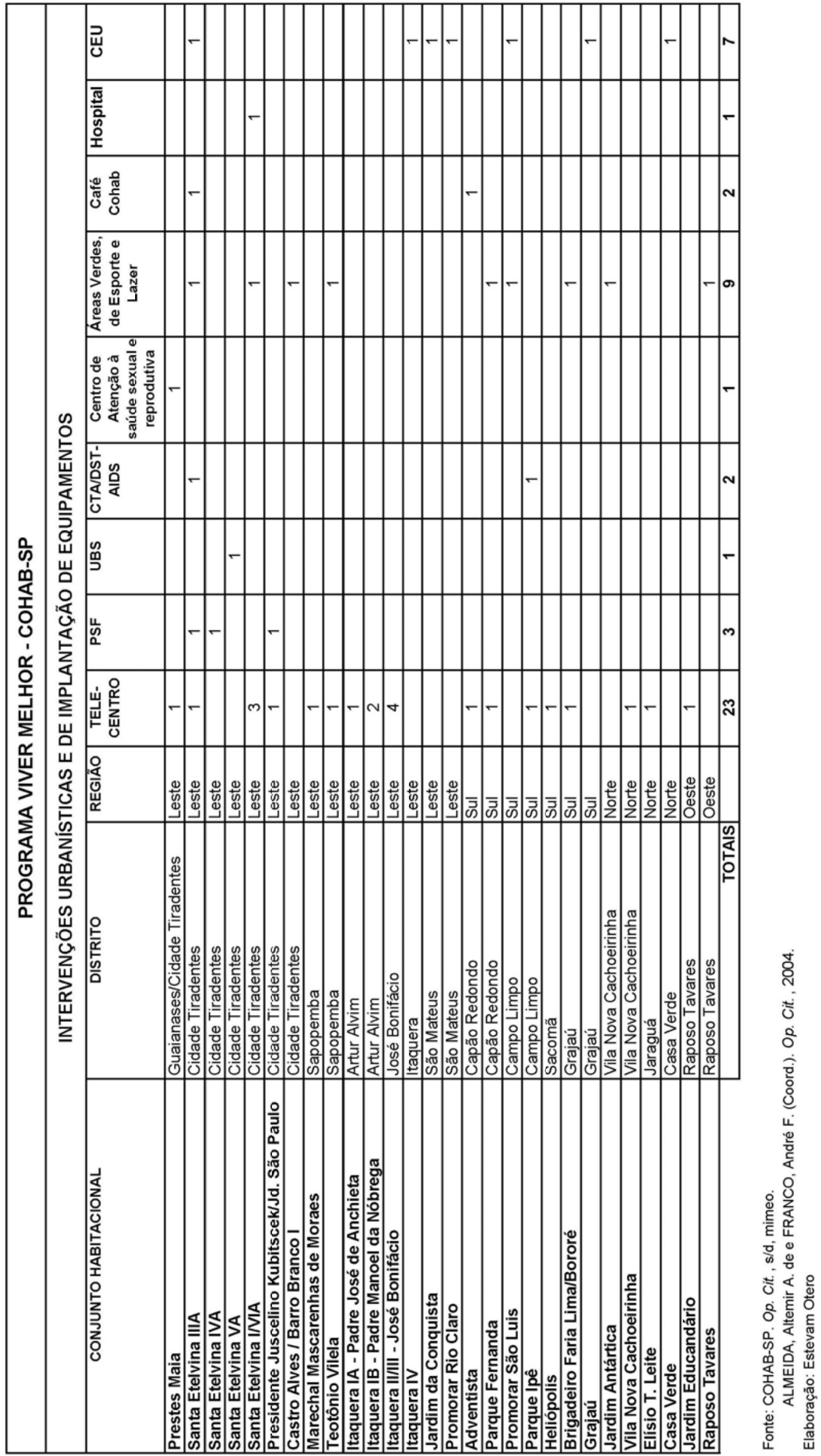


Diversos centros comunitários e centros comerciais da Companhia, que se encontravam ociosos ou subutilizados, foram aproveitados pelo programa. Os projetos de reforma e adaptação eram realizados pelos arquitetos da COHAB-SP e as obras executadas pelos próprios funcionários responsáveis pela manutenção dos conjuntos ${ }^{25}$.

O Viver Melhor constituía-se, dessa forma, num programa de baixíssimo custo, uma vez que permitia a implantação de equipamentos simplesmente com a cessão de áreas que já faziam parte do patrimônio da COHAB-SP. Mesmo nos imóveis edificados as intervenções consistiam em adaptações de baixo custo, podendo ser realizadas, muitas vezes, pelas equipes de manutenção da própria Companhia.

Desde o projeto-piloto ficava evidente o caráter do programa de implementar ações de forma articulada e integrada com outros órgãos, secretarias e entidades. Apesar de um enfoque maior no que se refere à implantação de equipamentos e serviços públicos e infra-estrutura ${ }^{26}$, o Viver Melhor desenhou ações voltadas à melhoria das condições de vida das populações residentes nos conjuntos habitacionais como um todo.

Além da cessão de áreas para implantação de equipamentos e serviços, o programa previu parcerias para a edificação de novas unidades habitacionais em áreas da Companhia representando, na maior parte das vezes, adensamentos de conjuntos já implantados. Por meio dessa parceria foram viabilizadas 1.965 novas unidades, sendo 1.064 moradias através do PAR - Programa de Arrendamento Residencial da Caixa Econômica Federal, além de 901 unidades em parceria com a CDHU - Companhia de Desenvolvimento Habitacional e Urbano do Governo do Estado de São Paulo.

Da mesma forma que as articulações com órgãos e secretarias do poder público, o Programa também buscou interlocutores na sociedade civil. De fato, a COHAB-SP era comumente procurada por entidades em busca de espaços para se instalarem e exercerem suas atividades. Várias dessas cessões foram malsucedidas devido à própria incapacidade de determinadas associações em gerirem adequadamente o espaço ${ }^{27}$. Um exemplo bemsucedido de cessão dentro do Viver Melhor foi o da Associação Pombas Urbanas, grupo de teatro que se instalou no prédio de um mercado desocupado à Av. dos Metalúrgicos em Cidade Tiradentes - um núcleo comercial da Companhia vazio e arruinado - e que passou a se constituir num importante pólo de manifestações culturais numa região em que estas

\footnotetext{
${ }^{25}$ Margareth Matiko Uemura. Entrevista...

${ }^{26}$ Conforme observado por Margareth Matiko Uemura, apesar de seu leque amplo de ações, o enfoque principal da atuação do Viver Melhor se deu sobre as questões físicas envolvidas na reabilitação dos conjuntos habitacionais da COHAB-SP. Entrevista...

${ }^{27}$ Altemir Almeida. Entrevista...
} 
praticamente não existiam ${ }^{28}$. Isso se apresenta ainda mais relevante uma vez que a cessão do espaço significou a transferência do grupo, há anos instalado na área central de São Paulo, para uma das periferias mais carentes de atividades culturais da cidade. Segundo Altemir Almeida a cessão de espaços da COHAB para entidades e associações particulares pautou-se pelo interesse público que adviria dessas cessões ${ }^{29}$.

\begin{tabular}{|c|c|c|c|c|c|}
\hline \multicolumn{6}{|c|}{ PROGRAMA VIVER MELHOR - COHAB-SP } \\
\hline \multicolumn{6}{|c|}{ PROVISÃO DE NOVAS UNIDADES HABITACIONAIS } \\
\hline $\begin{array}{c}\text { CONJUNTOS COM } \\
\text { PRODUÇÃO DE NOVAS } \\
\text { UNIDADES PRONTAS }\end{array}$ & DISTRITO & REGIÃO & MUTIRÕES & DISTRITO & REGIÃO \\
\hline \begin{tabular}{|l} 
Sítio Conceição \\
Inácio Monteiro \\
Barro Branco II \\
Santa Eltelvina INIA \\
Santa Etelvina IIA \\
Santa Etelvina VII \\
Itaquera IA \\
Itaquera IB \\
José Bonifácio \\
Adventista \\
Valo Velho II \\
Raposo Tavares \\
Teotônio Vilela \\
Heliópolis C \\
Jd. das Acácias \\
Jd. Antártica
\end{tabular} & $\begin{array}{l}\text { Cidade Tiradentes } \\
\text { Cidade Tiradentes } \\
\text { Cidade Tiradentes } \\
\text { Cidade Tiradentes } \\
\text { Cidade Tiradentes } \\
\text { Cidade Tiradentes } \\
\text { Artur Alvim } \\
\text { Artur Alvim } \\
\text { José Bonifácio } \\
\text { Capão Redondo } \\
\text { Capão Redondo } \\
\text { Raposo Tavares } \\
\text { Sapopemba } \\
\text { Sacomã } \\
\text { Grajaú } \\
\text { Vila Nova Cachoeirinha }\end{array}$ & \begin{tabular}{|l} 
Leste \\
Leste \\
Leste \\
Leste \\
Leste \\
Leste \\
Leste \\
Leste \\
Leste \\
Sul \\
Sul \\
Sul \\
Sul \\
Sul \\
Sul \\
Norte
\end{tabular} & \begin{tabular}{|l|} 
Barro Branco I \\
Barro Branco II \\
Santa Etelvina INIA \\
Santa Etelvina IVA \\
Sítio Conceição \\
Boa Esperança - Carrãozinho \\
Valo Velho I \\
Sônia Ingá (Adventista) \\
Nossa Senhora da Penha \\
Jardim Educandário
\end{tabular} & $\begin{array}{l}\text { Cidade Tiradentes } \\
\text { Cidade Tiradentes } \\
\text { Cidade Tiradentes } \\
\text { Cidade Tiradentes } \\
\text { Cidade Tiradentes } \\
\text { Tatuapé } \\
\text { Capão Redondo } \\
\text { Capão Redondo } \\
\text { Vila Nova Cachoeirinha } \\
\text { Raposo Tavares }\end{array}$ & \begin{tabular}{|l} 
Leste \\
Leste \\
Leste \\
Leste \\
Leste \\
Leste \\
Sul \\
Sul \\
Norte \\
Oeste
\end{tabular} \\
\hline
\end{tabular}

Fonte: COHAB-SP. Op. Cit. , s/d, mimeo.

Elaboração: Estevam Otero

O subprograma "Contas em dia, documentação em ordem" destinava-se a reduzir a inadimplência, altíssima a essa época, por meio da renegociação das prestações em atraso, bem como regularizar as ocupações em desacordo com a legislação. Assim o subprograma dividia-se em dois: "Contas em dia", voltado à renegociação das prestações atrasadas com o estabelecimento de novas condições de pagamento, redução do valor das prestações e do saldo devedor. O "Documentação em ordem" (Programa de Regularização de Ocupações - PRO) objetivava a regularização da situação de inúmeros moradores que ocupavam imóveis de forma irregular, e que passaram a ser proprietários daqueles em que já residiam, pelos quais passaram a pagar prestações acessíveis. Cerca de 40 mil residentes foram beneficiados por este subprograma, sendo que, destes, aproximadamente 30 mil encontravam-se em situação de ocupação irregular do imóvel ${ }^{30}$.

\footnotetext{
${ }^{28}$ Cf. LEITE, Eleilson. Semeando asas na quebrada paulistana in Le Monde Diplomatique Brasil, junho de 2008.

${ }^{29}$ Altemir Almeida. Entrevista...

${ }^{30}$ Cf. ALMEIDA, Altemir A. de e FRANCO, André F. (Coord.). Op. Cit., 2004, p. 30.
} 
Outro subprograma instituído com a finalidade de remover os entraves legais e burocráticos nos conjuntos referia-se à regularização fundiária de alguns destes. No total foram regularizadas 9.397 unidades em 18 conjuntos habitacionais ${ }^{31}$. Além da regularização fundiária dos conjuntos implantados, parte deste subprograma visou estender essa ação às áreas invadidas da Companhia, por meio do seu levantamento e encaminhamento aos órgãos do poder público a quem cabia a atribuição de sua regularização fundiária e urbanísticia ${ }^{32}$.

Outra das ações do Viver Melhor voltada à regularização das condições de ocupação foi a renegociação dos aluguéis dos imóveis comerciais da COHAB-SP. O reajuste desses valores por vezes distorcia e tornava irreais esses custos aos locatários, levando-os à inadimplência. A revisão desses contratos visou alterar a lógica da permissão onerosa, cujo princípio até aquele momento era o de auferir renda para a Companhia, privilegiando a ocupação dos estabelecimentos em função do interesse público. A Companhia passou a considerar que o custo social do abandono dos imóveis era muito maior que o possível lucro obtido em um contrato de valor mais elevado, similar aos valores de mercado ${ }^{33}$. Para tanto foi feita a reavaliação dos imóveis comerciais locados a permissionários, adequando os valores à realidade socioeconômica dos conjuntos e mudando o índice de reajuste do aluguel do IGP-M para o INPC, além da renegociação das dívidas e aluguéis em atraso, com descontos das parcelas dos débitos anteriores e da multa contratual. As permissões de uso gratuitas de que algumas entidades sem fins lucrativos usufruíam também foram revistas e reavaliadas, de acordo com a relevância do trabalho por elas desenvolvido ${ }^{34}$. Infelizmente não foi possível ter acesso a dados quantitativos que demonstrassem o alcance desta ação.

A despeito dessas ações e subprogramas, o programa caracterizava-se, porém, por um destacado caráter urbanístico, como expresso por sua primeira Coordenadora Técnica. Analisando o programa sob a estrutura de avaliação formulada por BLOS podemos verificar que este enfrentou a problemática do cotidiano dos conjuntos, por um lado, de forma territorialmente circunscrita aos limites dos conjuntos da COHAB-SP, e não poderia ser de outra forma, visto que a Companhia tem limitações próprias ao seu escopo de atuação e a suas propriedades fundiárias ou edificadas para investir na reabilitação dessas áreas.

\footnotetext{
${ }^{31}$ Cf. ALMEIDA, Altemir A. de e FRANCO, André F. (Coord.). Op. Cit., 2004, p. 31.

${ }^{32}$ COHAB-SP. Op. Cit., s/d, mimeo.

${ }^{33}$ Altemir Almeida. Entrevista...

${ }^{34}$ COHAB-SP. Op. Cit., s/d, mimeo.
} 


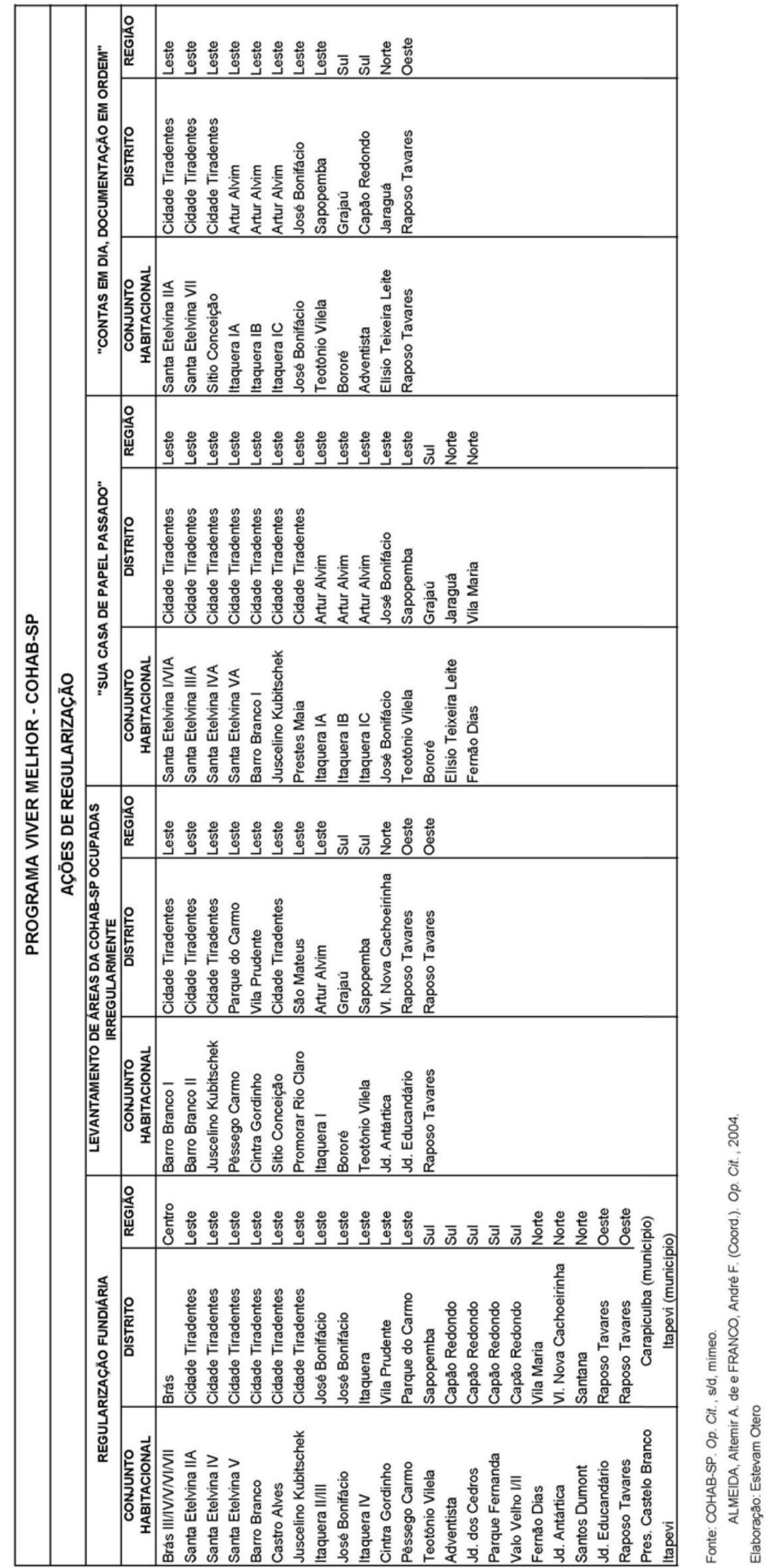


Por outro lado, essas ações enfrentavam os problemas cotidianos dos conjuntos de modo a qualificar e ampliar sua integração física por meio da implantação de equipamentos pontuais. A partir dessa ação diminuía-se a precariedade urbana dos conjuntos qualificando-os fisicamente e gerando melhorias sociais ao ampliar a oferta de serviços.

O enfrentamento das questões envolvendo a integração funcional e social dos conjuntos à cidade consolidada permanecia sem resposta pelo Viver Melhor, de modo que a desintegração e o isolamento dessas áreas em relação à dinâmica econômica e social de São Paulo seguiam inalterados.

Dadas as características da produção dos grandes conjuntos em São Paulo e a complexidade de seus problemas (como analisado ao longo do capítulo 3 deste trabalho) verifica-se que estes extrapolam seus limites físicos, estabelecendo relações com seu entorno imediato e com a cidade consolidada.

Comparativamente aos programas estudados no subcapítulo 1.5 da presente dissertação "Os programas públicos de reabilitação dos grandes conjuntos habitacionais na Europa", observamos uma progressiva evolução dos programas de reabilitação na Europa em termos de escopo e de alcance territorial, sobretudo na França, até abarcar a aglomeração urbana como um todo, e atacando os problemas em várias dimensões. No caso do Viver Melhor, a atuação circunscrita ao perímetro dos conjuntos que o caracterizou o faz se assemelhar mais ao programa madrilenho de Remodelación de Barrios (ainda que com pretensões ainda mais reduzidas) que à experiência de reabilitação francesa.

É preciso ressaltar, porém, as diferenças entre as duas realidades: em Madri, a expansão urbana acabou por englobar os polígonos de vivienda, levando a que estes assumissem uma posição bastante privilegiada, relativamente, à centralidade metropolitana. Logo, a luta dessas populações por melhor qualidade de vida era também a luta pela permanência nesses locais, que passaram a apresentar "vantagens comparativas" e, portanto, pressões por sua expulsão. No caso espanhol, as ações de requalificação desses conjuntos eram necessariamente focadas e locais, situação muito diferente da realidade dos grandes conjuntos paulistanos. A realidade dos grandes conjuntos de São Paulo exigiria, para sua superação, ações que partissem de sua relação com a aglomeração metropolitana e dessem respostas em termos de sua integração plena à dinâmica urbana, social e econômica.

Nesta limitação de partida se assenta uma das fragilidades do Viver Melhor, uma vez que o mesmo esteve restrito às propriedades da COHAB-SP, portanto, aos perímetros dos conjuntos. Uma das razões de sua rápida e barata viabilização - o extenso patrimônio 
fundiário sem uso da Companhia - converte-se numa de suas limitações. Dessa forma, o enfrentamento das questões envolvendo acessibilidade urbana e a integração econômica e social desse território e dessa população, por exemplo, ficavam totalmente alijadas do escopo do programa.

Mesmo questões inscritas no perímetro dos conjuntos, caso dos problemas decorrentes da monofuncionalidade, rigidez formal e irregularidades na ocupação das áreas condominiais, comuns nos conjuntos objeto das ações do programa, não foram atendidas entre os objetivos do Viver Melhor. Não que esses pontos não preocupassem os gestores do programa ${ }^{35}$; entretanto, não encontraram respostas possíveis dentro das possibilidades abertas pelo Viver Melhor.

Outro problema considerável do programa diz respeito ao seu próprio desenho institucional. Como observado por Renata Milanesi ${ }^{36}$, o programa jamais foi formalizado nem como estrutura executiva nem como programa oficial dotado de recursos. À exigüidade da equipe (que raramente ultrapassou a função do Coordenador Técnico) somou-se a inexistência de uma dotação orçamentária que permitisse sustentar as ações do programa para além de parcerias localizadas, impedindo que a Companhia realizasse intervenções de maior monta na requalificação física de determinadas áreas.

Sinteticamente, o Viver Melhor pode ser descrito como um grande esforço de articulação de ações de distintos órgãos, secretarias e entidades, coordenado pela COHAB-SP, com o fim de equipar os grandes conjuntos implantados pela municipalidade por meio da utilização de seu estoque de terras e edificações públicas sem uso.

Se, por um lado, as ações de implantação de equipamentos, serviços e infraestrutura acabaram por diminuir as desigualdades entre os grandes conjuntos e a cidade consolidada, não chegaram a alterar a lógica segregacionista refletida nesses espaços. A partir do Viver Melhor abriu-se a perspectiva de que com a implantação de equipamentos e a disponibilização de serviços públicos seriam melhoradas a qualidade ambiental e a qualidade de vida nesses conjuntos. Contudo, segundo Altemir Almeida, era-se modesto na expectativa com relação aos resultados: não se tinha a pretensão de romper com as condições de segregação das áreas, mas, sim, melhorar as condições de vida dessa população. "Não se tinha a expectativa de enfrentar a segregação até sua superação a partir do Viver Melhor. O Programa era mais modesto"37.

\footnotetext{
${ }^{35}$ O que motivou uma incipiente discussão entre os gestores do programa e a Subprefeitura da Penha, como já relatado anteriormente. Altemir Almeida. Entrevista...

${ }^{36}$ Renata Milanesi. Entrevista...

37 Altemir Almeida. Entrevista...
} 
Segundo avaliação de Almeida, para que se tivesse essa abrangência ou essa perspectiva de impactar decisivamente na questão da segregação urbana, seria necessário um programa mais amplo, possivelmente articulado a partir de uma ação intersecretarial, coordenada a partir do Gabinete do Prefeito, constituindo-se, verdadeiramente, numa política de governo, uma vez que as questões suscitadas por esse enfrentamento transcendem o âmbito e alcance da atuação de um órgão como a COHAB.

Aí reside, possivelmente, o grande problema em se esperar do Viver Melhor a redução da segregação socioespacial dos moradores dos grandes conjuntos habitacionais de São Paulo. Dessa maneira, parece que o programa atingiu, de certa forma, seus objetivos ao mesmo tempo em que encontrava seus limites, demonstrando que para esse enfrentamento se faz necessária uma formulação mais ampla e abrangente.

Este fato é ainda mais revelador quando se analisa a situação do complexo Cidade Tiradentes, onde a sobreposição de problemas de diversas escalas e características, impede sua resolução por meio de ações de caráter tão pontual, sem abranger a relação do complexo com a cidade. Se impactou favoravelmente a qualidade de vida dos moradores de Cidade Tiradentes, o Viver Melhor ainda é um passo pequeno na reabilitação do complexo em direção ao pleno direito à cidade a seus habitantes.

A partir de 2005, com a mudança de comando na administração municipal, o Viver Melhor teve interrompidas suas operações, a despeito de o programa jamais ter passado por uma avaliação pelo próprio poder público acerca de seus sucessos, percalços ou fracassos. A questão da reabilitação dos grandes conjuntos habitacionais de São Paulo deixou de ser pensada em termos de política pública, como debate em torno de seus objetivos, alcance, abrangência ou resultados, voltando a ser uma demanda difusa acerca de um "passivo" a ser enfrentado num futuro sem perspectiva de ser alcançado a médio prazo.

\subsection{Perspectivas presentes e futuras à reabilitação dos grandes conjuntos de São Paulo}

O presente contexto das condições de vida nas periferias de São Paulo é, fruto de uma constatação empírica, melhor que no fim dos anos 1990 e início do século XXI, tanto econômica quanto socialmente, reflexo, muito possivelmente, da melhora considerável no quadro econômico nacional nos últimos anos. Ainda que seja de difícil mensuração, é verificável uma lenta, mas progressiva melhora nos indicadores de renda e de 
desenvolvimento humano na cidade. Caberia perguntar até que ponto essa transformação vem impactando os grandes conjuntos de São Paulo.

Nossa visita ao Complexo Cidade Tiradentes constatou, a partir da fala de residentes no local, uma percepção corrente de que a região passa por uma melhora em diversas dimensões. Foram-nos relatadas melhorias na renda, em relação aos equipamentos públicos, às áreas verdes e de lazer e, inclusive, na redução da criminalidade. Além disso, as melhorias urbanas verificadas no complexo entre nossa primeira visita em outubro de 2002 e o levantamento realizado em fevereiro de 2008, certamente resultado da conjugação da melhoria econômica nacional com implantação de equipamentos e serviços urbanos ocorrida no último período, nos permitiria afirmar que a região apresenta uma evolução no quadro do contexto metropolitano.

Entretanto, como já mencionado no subcapítulo anterior, o processo segregatório que estrutura o espaço urbano brasileiro e paulistano não poderá ser superado tãosomente com políticas pontuais e limitadas, como as que analisamos até aqui. A sobreposição de precariedades encontrada nos grandes conjuntos habitacionais demanda amplos programas de ação, de modo a permitir a ruptura com a rigidez e monofuncionalidade que os caracterizam, assim como sua integração à dinâmica urbana e econômica da metrópole. Essas ações deveriam ultrapassar, em muito, a simples implantação de equipamentos e serviços públicos, constituindo-se estes apenas no primeiro passo no sentido de sua reabilitação; passo este que já foi dado, mas que, como pode ser facilmente verificado, mantém esses espaços muito distantes de superar a segregação e alienação urbanas a que estão submetidos.

A despeito de não se voltar objetivamente ao desenho de ações para a reabilitação dos grandes conjuntos, o Plano Diretor Estratégico do Município de São Paulo $^{38}$ elencava propostas destinadas à reestruturação do território do extremo da Zona Leste, cuja abrangência englobaria alguns dos maiores complexos de conjuntos da COHAB-SP aí localizados: Cidade Tiradentes, Itaquera I (distrito Artur Alvim) e Itaquera II e III (distrito José Bonifácio). Deve-se analisar com ceticismo este instrumento legislativo, cuja existência em nenhum momento garantiu ou possibilitou um desenvolvimento urbano mais equânime e democrático ${ }^{39}$.

O novo Plano Diretor definiu, em seu artigo 225, parágrafo $2^{\circ}$, a Operação Urbana Consorciada Rio Verde-Jacú no extremo da Zona Leste, acompanhando o eixo da avenida

\footnotetext{
${ }^{38}$ Lei Municipal no 13.430, de 13 de setembro de 2002.

39 Uma análise acerca das contradições do Plano Diretor Estratégico do Município de São Paulo podem ser encontrados em VILLAÇA, Flávio. As Ilusões do Plano Diretor. São Paulo: FV, 2005.
} 
Jacu-Pêssego, projetada para, quando concluída, fazer a ligação entre Guarulhos e a região do $A B C$ paulista. Como todas as operações urbanas consorciadas esta representava um

conjunto de medidas coordenadas pelo Município com a participação dos proprietários, moradores, usuários permanentes e investidores privados, com o objetivo de alcançar transformações urbanísticas estruturais, melhorias sociais e a valorização ambiental, notadamente ampliando os espaços públicos, organizando o transporte coletivo, implantando programas habitacionais de interesse social e de melhorias de infra-estrutura e sistema viário ${ }^{40}$

A operação acenava com a possibilidade de integração econômica e física dessa região que concentra os grandes conjuntos de São Paulo: o perímetro da operação engloba trechos do complexo José Bonifácio (Itaqueras II e III) e Cidade Tiradentes, além de localizar-se a menos de três quilômetros do grande conjunto Itaquera I.

Ao perímetro da Operação Urbana sobrepunha-se a Área de Intervenção Urbana do Projeto Estratégico do Programa de Desenvolvimento Econômico Leste - AIUPRODEL ${ }^{41}$ com o objetivo declarado de promover o desenvolvimento econômico e social do extremo da Zona Leste, por meio do estabelecimento de incentivos urbanísticos, tributários e programas de crédito destinados às atividades econômicas, procurando eliminar o caráter de "cidade-dormitório" que esse território apresenta ${ }^{42}$. Até o momento

\footnotetext{
${ }^{40}$ Lei Municipal no 13.430, artigo 225.

${ }^{41}$ Lei Municipal $n^{\circ}$ 13.885, de 25 de agosto de 2004, artigo 64. Dentre os objetivos e diretrizes dessa lei constavam:

I. promover a melhor distribuição das atividades econômicas na região leste;

II. ampliar a oferta de empregos na área do extremo leste da cidade e melhorar a sua distribuição intraregional;

III. promover as atividades econômicas, considerando a vocação regional, o perfil da população economicamente ativa e as tendências do mercado;

IV. promover a qualificação econômica do eixo Jacu-Pêssego, valendo-se das vantagens locacionais da ligação porto - aeroporto;

V. fomentar a implantação de cadeias produtivas com alta absorção empregatícia com capacidade para alavancar setores da indústria, do comércio e dos serviços, estrategicamente selecionados segundo as potencialidades econômicas regionais;

VI. revitalizar e ampliar a função pública do Parque do Carmo, por meio da implantação de equipamentos sociais de âmbito metropolitano tais como: nova universidade, centro de pesquisas tecnológicas e centro olímpico.

${ }^{42}$ Em seu artigo 65, a lei enumera as ações estratégicas para a consecução do programa:

I. implantar a operação urbana consorciada Rio Verde-Jacú, em duas partes, compostas por dois perímetros aprovados por lei específica;

II. executar, com prioridade, a complementação da Avenida Jacu-Pêssego desde o ABC até Guarulhos e o prolongamento da avenida Radial Leste até Guaianases;

III. estabelecer incentivos urbanísticos, tributários e programas de crédito destinados às atividades econômicas indicadas pelo Programa;

IV. compatibilizar a regulação de uso e ocupação do solo às atividades econômicas indicadas pelo Programa;

V. implantar centros de formação e capacitação profissional convergentes às diretrizes de desenvolvimento econômico indicadas pelo Programa;
} 
nenhuma das ações previstas foi implementada, ao que é preciso acrescentar, inclusive, o questionamento à capacidade de se levar a cabo tantas operações urbanas concomitantemente, visto que nem na região da avenida Faria Lima o mercado imobiliário foi capaz de utilizar todo o potencial construtivo disponível. A Operação Urbana Consorciada Rio Verde-Jacú segue apenas como um enunciado vago no conjunto de boas intenções e poucas ações do Plano Diretor Estratégico do município de São Paulo, de modo que se revelam pouco plausíveis as possibilidades de alguma efetividade desse instrumento.

Uma ação estrutural que possibilitaria impactar positivamente as condições de mobilidade e acessibilidade na região da Zona Leste, sobretudo no Complexo Cidade Tiradentes, seria a conclusão do Expresso Tiradentes $^{43}$, projeto que visa a implantação de vias expressas para a circulação de ônibus e que prevê a integração entre a área central e aquele distrito. Projeto lançado na campanha eleitoral para prefeito de São Paulo em 1996 sob o nome Fura-Fila, após ser reestruturado inúmeras vezes e já ter consumido milhões de reais, ainda não tem previsão de atingir seu ponto final, o que representaria melhorias consideráveis na questão da acessibilidade ao distrito que apresenta os piores índices da cidade quanto a esse indicador.

Contudo, um dos temas mais relevantes na qualificação urbanística e ambiental dos grandes conjuntos segue sem nenhuma proposta e sem perspectiva de ação: a monotonia, rigidez e monofuncionalidade tão típicas desses espaços. Até o presente, as únicas soluções a essa questão estão representadas pelas intervenções irregulares nas áreas condominiais dos edifícios e nas ampliações e mudanças de uso nas unidades

\footnotetext{
VI. promover gestões junto a SABESP para instalação de infra-estrutura de saneamento e, em especial, de um novo reservatório elevado no limite do Parque do Carmo;

VII. destinar área para terminal de cargas logístico;

VIII. promover a requalificação urbanística das centralidades lineares e polares;

IX. implementar políticas públicas para incubar novas atividades econômicas na Região Leste;

$\mathrm{X}$. implementar políticas públicas para dinamizar setores econômicos consolidados e setores emergentes na Região Leste;

$\mathrm{XI}$. mobilizar os recursos gerados pelas transformações urbanísticas propostas no entorno do eixo Jacu-Pêssego para o desenvolvimento do extremo leste;

XII. estimular o tripé da economia metropolitana: indústria de ponta, serviços relacionados com a demanda internacional e nacional, e a formação e capacitação profissional por meio de instituições de ensino e pesquisa distribuídas territorialmente de forma equilibrada;

XIII. desenvolver linhas de pesquisa aplicada em economia urbana regional para identificar atividades dinâmicas compatíveis com a Região Leste e com a economia globalizada;

XIV. promover a articulação política inter-regional das Subprefeituras da Região Leste, em prol do desenvolvimento econômico-social;

$\mathrm{XV}$. resgatar a economia informal para a formalidade legal, notadamente o comércio ambulante;

XVI. implementar projetos, programas e políticas públicas voltadas para a economia solidária;

XVII. implementar pólo de entretenimento, centro de eventos e atividades culturais;

XVIII. integrar e incentivar a agricultura urbana sustentável nas ZEPAGs.

${ }^{43}$ Para maiores informações ver SPTrans. Expresso Tiradentes: corredor Parque D. Pedro II - Cidade Tiradentes. São Paulo: SPTrans, 2006.
} 
unifamiliares, garantindo alguma diversidade - ainda que precária e ilegal - aos conjuntos da COHAB-SP.

Apesar da constatação do problema o poder público finge ignorar sua existência, aguardando que a consolidação dos conjuntos resolva o problema por si só. A questão, fruto direto de decisões projetuais equivocadas e representativas de um momento histórico - e já superado - do pensamento urbanístico, demanda uma resposta nos mesmos termos.

É incrível e surpreendente que boa parte das intervenções que conferiram alguma urbanidade aos grandes conjuntos seja representada por irregularidades e ações clandestinas das pessoas que aí residem e que procuram responder a suas necessidades e demandas por meio da soma dessas ações individuais.

A necessidade de uma resposta do poder público, visando corrigir premissas projetuais equivocadas faz-se premente, ao que devem concorrer intervenções físicas e alterações legislativas, com o intuito de permitir a regularização urbanística e transformações nos grandes conjuntos visando atender ao interesse público. 
CONSIDERAÇÕES FINAIS 
A questão da habitação às classes trabalhadoras mobilizou grande parte do debate arquitetônico e urbanístico desde o século XIX, atingindo seu ápice no início do século $X X$, quando foram delineadas as linhas gerais daquilo que veio a ser denominado Movimento Moderno em Arquitetura, e que definiu as bases sobre as quais se estruturou a cidade moderna, com seu dogmatismo acerca da separação das funções da cidade: habitar, circular, trabalhar e divertir-se (nas horas livres).

Das pretensões originais do Movimento Moderno em edificar um mundo novo, o "Neue Welt", a partir do enfrentamento das contradições urbanas e sociais por meio da Arquitetura, passou-se a um momento, logo após o término da Segunda Grande Guerra, em que as utopias libertárias deram lugar à instrumentalização dos preceitos modernos para a reconstrução do pós-guerra, fundamentais que foram à reorganização da produção e do consumo, especialmente num contexto de formação de um mercado capitalista de consumo de massa.

$\mathrm{Na}$ esteira da transposição da racionalidade da indústria à produção do espaço urbano, esse dogmatismo, implementado sob o Estado de Bem-Estar estruturado na Europa, acabou por reduzir a questão da moradia à multiplicação de unidades habitacionais, ao enfrentar a questão do déficit habitacional por meio da produção de milhares de unidades, em espaços que não se tornavam (e nem se tornariam) cidade. $O$ trabalhador obteve sua moradia mas perdeu a cidade.

A urgência da produção massiva acarretou em resultados urbanísticos desastrosos. Especialmente na França esse tipo de atuação, sob a forma de produção dos grands ensembles, marcou indelevelmente a paisagem suburbana das grandes cidades, sobretudo Paris, a partir da multiplicação de torres e lâminas de concreto e aço, que reproduziam uma morfologia pobre e rígida, constituindo vastas cidades-dormitório precariamente vinculadas aos outros usos e funções da cidade. Ainda assim, ao longo das primeiras décadas, os grandes conjuntos possibilitaram o atendimento adequado às necessidades habitacionais da classe trabalhadora; num cenário econômico favorável, os grands ensembles permitiram aos operários franceses uma moradia digna (como em nenhum momento histórico anterior) e um horizonte em que se delineava a perspectiva de ascensão social. Os grandes conjuntos franceses acabaram funcionando, verdadeiramente, como um "trampolim" àquelas populações que, em virtude de melhorias socioeconômicas, acabavam deixando os conjuntos.

Às críticas que se avolumavam contra essa forma urbana na França, o Estado nacional respondeu, em 1973, com a proibição da construção dos grandes conjuntos. Fica claro que os mesmos só foram proibidos quando não se fizeram mais necessários, e a 
questão da demanda habitacional massiva já havia sido equacionada, especialmente quando comparadas com as condições habitacionais vividas pela classe trabalhadora até a primeira metade do século XX.

As condições de segregação e alienação urbanas - já presentes nesses territórios desde sua implantação - acirraram-se sobremaneira a partir da crise econômica instalada com os choques do petróleo na década de 1970, ao que foi acompanhada pela progressiva substituição das populações dos conjuntos de residentes de origem francesa por imigrantes, principalmente do norte da África. Às dificuldades inerentes aos problemas espaciais veio se somar a concentração da população socialmente mais frágil do país. Em princípios dos anos 1980 a sobreposição de problemas espaciais com mazelas sociais levou, finalmente, à explosão em ondas de protesto e violência, tendo os grandes conjuntos por palco.

Como resposta a esses conflitos latentes formularam-se diagnósticos que buscavam as origens dos problemas e as possibilidades de superação. As críticas direcionaram-se, inicialmente, aos aspectos formais dos conjuntos e às condições físicas, quer seja em sua relação com o restante da cidade quer seja no tocante à oferta de equipamentos e infra-estrutura.

Desde os primeiros anos da década de 1980 inúmeros programas e ações foram desenvolvidos com o intuito de melhorar a qualidade de vida nos conjuntos periféricos franceses, evoluindo de ações pontuais e restritas aos seus limites até atingir o nível de grandes políticas nacionais de intervenção em escala regional passando a enfocar a dinâmica urbana como um todo e a necessidade de atuar sobre a relação dos grandes conjuntos habitacionais com as cidades que os abrigam. Alguns conjuntos receberam intervenções de praticamente todos os programas que foram se sucedendo ao longo de quase três décadas. Ainda assim continuam a observar um cenário de degradação ambiental e conflito social.

A grande questão subjacente é que nenhum destes programas - por mais amplos e complexos que fossem seus desenhos de operação - atuou no enfrentamento aos mecanismos que (re)produziam as condições de segregação espacial e exclusão social. Inclusive, estes programas foram levadas a cabo no momento em que mais avançaram as políticas de desregulamentação e liberalização econômica, em que mais se solaparam direitos sociais, procurando-se responder, contraditoriamente, a problemas sociais e econômicos estruturais com políticas pontuais e superficiais.

No caso brasileiro, o modelo de atuação estatal na questão da moradia por meio da produção de unidades sob a forma conjunto habitacional, com seus equívocos e 
idiossincrasias, foi transposto sem maiores considerações, com o agravante de que, aqui, a implementação dos grandes conjuntos teve início ao mesmo tempo em que este modelo era severamente questionado na própria matriz européia.

Ao longo do século $X X$ o Brasil atravessou um processo de urbanização e industrialização vertiginoso. Esse processo passou a demandar investimento na produção de novas habitações e de infra-estrutura urbana. Contudo, a universalização do direito à cidade, à moradia digna assim como o acesso às redes de serviços urbanos jamais ultrapassou a retórica dos discursos oficiais para figurar como uma das prioridades de ação do Estado brasileiro.

A atuação do Estado na constituição de políticas voltadas ao enfrentamento das carências habitacionais ganha relevância a partir da Revolução de 30, com "a redefinição das relações entre Estado e classes dominadas" de um lado, e "o agravamento das condições habitacionais nos centros urbanos" ${ }^{1}$ de outro. É nesse momento que são constituídos os IAPs que, apesar de sua função precípua como órgãos previdenciários, foram os principais promotores habitacionais do período. Estas ações tiveram motivações de ordem político-ideológica: por um lado buscavam ampliar a base de sustentação do novo governo entre os trabalhadores urbanos, ao mesmo tempo em que evitavam questionamentos à estrutura capitalista.

Com a promulgação da Lei do Inquilinato, em 1942, o Estado brasileiro passa a intervir diretamente na regulação do valor dos aluguéis, até então a principal forma de acesso à habitação nos centros urbanos, proibindo seus reajustes. Essa medida atuou no controle do custo de reprodução da força de trabalho, diminuindo a pressão por reajustes salariais; atuou na ampliação da base de sustentação do Estado Novo, pois ia ao encontro da grande massa de locatários que foi beneficiada; reduziu drasticamente a atratividade do investimento imobiliário eliminando, de um lado, a classe não-produtiva dos rentistas urbanos e, de outro, reorientando os capitais que estavam imobilizados no mercado imobiliário para o setor produtivo em expansão. Seus reflexos foram a diminuição da produção de novas moradias de aluguel e o aumento da carência de unidades habitacionais, resultando na expansão acelerada da urbanização periférica, baseada na autoconstrução, em loteamentos clandestinos e favelas. Esta se converteu na forma predominante de "urbanização" no Brasil ao longo do século XX. As ações públicas de enfrentamento da questão habitacional caracterizaram-se mais pelas iniciativas pontuais, quase irrelevantes, frente às dimensões do problema.

\footnotetext{
${ }^{1}$ FARAH, Marta. Op. Cit., 1983, p. 6.
} 
A alternativa representada pela moradia e urbanização precárias funcionou como uma válvula de escape às demandas das classes trabalhadoras, excluídas do mercado capitalista de promoção habitacional devido ao contexto nacional de "industrialização com baixos salários", onde mesmo aqueles trabalhadores integrados aos circuitos mais avançados do capitalismo mundial encontravam-se excluídos dos meios de promoção capitalista da habitação e do espaço urbano.

O Estado brasileiro, durante os governos populistas entre 1945 e 1964, em momento algum colocou a questão da moradia urbana entre suas prioridades. A Fundação da Casa Popular, criada em 1946, e vinculada ideologicamente à casa própria como meio de desmobilizar politicamente os trabalhadores urbanos, jamais conseguiu articular nacionalmente um programa de desenvolvimento habitacional, permanecendo presa a práticas clientelísticas, acabando por sucumbir às contradições desses governos populistas mais concentrados nos dividendos políticos auferidos com a construção de unidades habitacionais que com o equacionamento do problema.

Uma política nacional de habitação popular, para além de ações descoordenadas e pontuais, só se concretizaria efetivamente com a criação, em 1964, do SFH - Sistema Financeiro da Habitação e do BNH - Banco Nacional da Habitação, incorporando grande parte das formulações e propostas que vieram sendo desenvolvidas ao longo dos anos anteriores. Sua implantação deveu-se às condições políticas de então, com a chegada ao poder de um governo com força política suficiente para impor esse novo modelo, por meio do golpe cívico-militar de 31 de março de 1964.

Se por um lado tinha entre seus objetivos manifestos a melhorias das condições de moradia das camadas populares, o SFH/BNH também previa, por outro lado, o incentivo à indústria da construção civil e à geração de empregos. Entre 1964 e 1986, período em que atuou, o SFH/BNH foi importante agente na dinamização e modernização do mercado da construção civil, sendo identificado por alguns autores, como MARICATO, como um dos principais responsáveis pela "estruturação e consolidação de um mercado imobiliário urbano capitalista"2 no Brasil.

O SFH/BNH foi fundamental na dinamização da promoção imobiliária e na verticalização das cidades brasileiras, na diversificação da indústria de materiais de construção e na consolidação das grandes construtoras, ao promover o financiamento à habitação, ao saneamento básico e à infra-estrutura urbana, além de importante ferramenta econômica para a geração de empregos para mão de obra não-especializada.

\footnotetext{
${ }^{2}$ MARICATO, Ermínia. Op. Cit., 1996, p. 44.
} 
O BNH chegou a ser, a partir de 1969, o segundo maior banco do país em magnitude de recursos, ao administrar fundos provenientes da poupança compulsória dos trabalhadores, o FGTS, e voluntária, o SBPE. Apesar da grandeza dos recursos envolvidos na operação do $\mathrm{SFH} / \mathrm{BNH}$, recursos esses responsáveis pelo financiamento de cerca de $25 \%$ de todo o incremento imobiliário residencial no período 1964-1986, este foi um momento em que a carência habitacional, representada pelo aumento no número de moradias em favelas e loteamentos precários, cresceu dramaticamente, uma vez que apenas $20 \%$ desse incremento é representado pelos segmentos de mais baixa renda ${ }^{3}$.

Sua atuação esteve muito distante de enfrentar a magnitude dos problemas relativos à carência habitacional das camadas populares. Sua constituição sob uma lógica eminentemente empresarial, que não comportava soluções subsidiadas, excluía de antemão os segmentos de mais baixa renda do acesso aos seus financiamentos. Após 22 anos de atividades, descapitalizado, com dívidas gigantescas e suspeitas de fraudes na concessão e operação de seus financiamentos, o SFH/BNH foi extinto em 1986.

Ao longo do período de atuação estatal mais efetiva na questão da moradia popular - período de vigência do $\mathrm{BNH}$ - em nenhum momento o real atendimento às demandas habitacionais das camadas de baixa renda efetivou-se como política de Estado destinada a universalizar o direito à moradia, ficando relegado à retórica dos discursos oficiais. O Estado procurou evitar qualquer tipo de ação que pudesse impactar no aumento dos custos de reprodução da força de trabalho, o que acabou restringindo o acesso da classe trabalhadora ao mercado habitacional capitalista (para o que necessitaria de aumentos salariais significativos ou amplas políticas de subsídio governamental). Em função disso FERREIRA vai afirmar que aos interesses das "classes dominantes industriais" a "'melhor' política habitacional, no contexto do subdesenvolvimento brasileiro, era a da 'não-política habitacional'”4.

O período de atuação do BNH foi o quantitativamente mais expressivo na promoção pública de unidades habitacionais. O atendimento voltado ao chamado "mercado popular", focando as camadas de um a três salários mínimos, posteriormente estendidas até cinco salários mínimos, esteve a cargo das COHABs - Companhias de Habitação. Uma primeira geração de programas voltados a esse segmento tinham por princípio a produção em massa de unidades, especificamente sob a forma-conjunto habitacional, calcada na experiência européia de reconstrução no pós-guerra.

\footnotetext{
${ }^{3}$ Cf. CHAFFUN, Nelson. Op. Cit., 1997, p. 26

${ }^{4}$ FERREIRA, João Sette Whitaker. Op. Cit., 2007, p. 45.
} 
A produção sob a forma de grandes conjuntos toma impulso definitivo a partir de 1975, em meio à distensão do regime autoritário, com uma progressiva perda qualitativa ao longo dos anos em relação àquelas primeiras intervenções desenvolvidas pelos IAPs e pelo DHP-DF, em escala e padrões desconhecidos no país até então. Os grandes blocos que, a essa época, já marcavam o cenário da banlieue parisiense - e lá sofriam forte questionamento -, passaram a ser produzidos na periferia paulistana, com resultados ainda piores.

Surgiram os "grandes conjuntos", inaugurados com a implantação de Itaquera I a partir de 1977, na Zona Leste de São Paulo. Marcados por uma progressiva e cada vez maior precariedade, os grandes conjuntos implantados pela COHAB-SP na periferia da metrópole paulistana foram se sucedendo: José Bonifácio (1979 a 1990), Cidade Tiradentes (1973 a 1998), Sapopemba (1982 a 1983), Educandário (1983 a 1988), Adventista (1986 a 1992), representaram grandes intervenções com projeto e recursos públicos, e que conseguiram levar ao limite a alienação urbana e a segregação socioespacial de vastos contingentes populacionais, chegando a representar, como no extremo da Zona Leste de São Paulo, proporção importante da população residente ${ }^{5}$.

Evidentemente que a realidade socioeconômica brasileira, por tão diversa da situação na França, apresenta características distintas no que se refere à gravidade das condições habitacionais e urbanas na comparação entre a periferia e a banlieue. O Estado de Bem-Estar social europeu promoveu uma política universalista e integradora no tocante à promoção habitacional às classes trabalhadoras. Lá, a crise que se abateu sobre os subúrbios é fruto de uma gama complexa de fatores com uma considerável carga étnica e cultural.

Aqui jamais vimos uma política urbana integradora e universal: as próprias características do BNH e sua lógica financeira conferiram ao sistema um traço excludente, que não atingia justamente os setores mais necessitados de sua atuação.

Ainda assim, a promoção dos grandes conjuntos representou uma produção significativa de unidades, bem como a constituição de vastos territórios onde se sobrepunham carências e problemas sociais, econômicos e urbanísticos, comumente agravados pelas próprias características dessa promoção.

\footnotetext{
${ }^{5}$ No distrito Artur Alvim, onde se encontra implantado o complexo Itaquera I, as unidades em conjuntos da COHAB-SP representam $39,43 \%$ do total de 31.713 moradias aí encontradas. No distrito José Bonifácio os conjuntos da Companhia respondem por $74,73 \%$ do total de 28.925 residências. Em Cidade Tiradentes essa proporção atinge $85,03 \%$ dos 49.840 domicílios existentes no distrito. Cf. Censo IBGE/2000; COHAB-SP acessado em 22 de dezembro de 2007 do site: "http://www6.prefeitura.sp.gov.br/empresas_autarquias/cohab/conjuntos_habitacionais/0001".
} 
Nesta pesquisa pôde-se constatar a baixa qualidade resultante dessa produção em que, a premissas projetuais equivocadas e já superadas na matriz em que foram concebidas, sobrepuseram-se as condições de segregação e exclusão tão típicas de nossa formação social. O resultado pode ser constatado nos espaços resultantes dessa política, onde uma forma urbana formulada originalmente como extensão da racionalidade da indústria ao espaço de moradia do trabalhador passa a se configurar como um exílio econômico e social dentro da metrópole.

A busca por terras de menor custo - muitas vezes com características rurais -, extremamente afastadas da centralidade metropolitana; a elaboração de projetos que enfocavam a questão dos custos unitários sem se preocupar com a constituição de espaços urbanos qualificados; a péssima qualidade de execução; a carência de equipamentos, serviços e infra-estrutura urbana, tudo isso impactou negativamente os conjuntos da Companhia.

A degradação presente nos grandes conjuntos da COHAB-SP tem origem em alguns problemas que, por suas características, podem ser agregados em dois grandes grupos: aqueles de natureza local, representados pelas carências de equipamentos e serviços públicos, a rigidez e monofuncionalidade tipológica e morfológica, assim como os problemas de ordem construtiva; e aqueles problemas que têm origem na relação dos conjuntos com a cidade, representados pelas dificuldades de acessibilidade e mobilidade, a distância aos postos de trabalho e pontos de consumo, a segregação socioespacial de seus moradores.

A constatação de que os conjuntos da COHAB-SP comportavam um sem-número de carências, constituindo uma dívida não saldada da Companhia com seus mutuários, ocorreu já há mais de duas décadas. Nesse meio tempo, algumas iniciativas foram tomadas com o intuito de reverter o quadro de precariedade e baixa qualidade de vida nesses espaços. Entretanto, apenas a partir de 2001 essas iniciativas traduziram-se no primeiro conjunto de ações organizado e articulado com o objetivo de reabilitar esses perímetros: o Programa Viver Melhor. Como visto, mesmo esta política pública foi fruto, inicialmente, de improvisações que acabaram por estruturar-se num programa maior e com premissas e objetivos melhor definidos.

Ainda que tenha atuado em várias frentes e com enfoques diversos, todos eles visando a melhoria da vida cotidiana das populações aí residentes, o Viver Melhor atuou naquele grupo de determinações de natureza local. Nenhuma das intervenções do Viver Melhor transcendeu os limites territoriais dos conjuntos implantados, não encarando aqueles problemas decorrentes, justamente, da relação desses perímetros com a cidade e 
sua dinâmica global. Ainda assim, as possibilidades abertas pelo Viver Melhor permitiram investir em escala considerável em equipamentos e serviços, a partir da articulação entre os diversos entes públicos, coordenados pela COHAB-SP. Sua operação se dava a partir da disponibilidade de terras e edificações da Companhia, o que constrangia as ações aos perímetros dos conjuntos habitacionais. Essa disponibilidade de próprios públicos, da mesma maneira que permitiu a rápida viabilização do programa, acabou impondo seus limites, uma vez que o agente coordenador do programa - a COHAB - tinha um horizonte de atuação bastante determinado por sua função precípua.

A magnitude dos problemas vividos nos grandes conjuntos paulistanos demandaria uma ação mais ampla e integrada. Não se deve, entretanto, reduzir a importância do Viver Melhor enquanto instrumento para a redução das desigualdades na oferta de serviços e equipamentos nos grandes conjuntos: sua implantação acarretou, ainda que superficialmente, na melhoria da qualidade de vida nessas áreas (ainda que isto se deva, fundamentalmente, ao fato de se partir de um patamar reconhecidamente baixo na oferta de serviços públicos).

O Viver Melhor conseguiu produzir melhorias relativamente importantes na escala dos bairros, enfrentando a desigualdade de equipamentos e infra-estrutura entre essas áreas e a cidade consolidada. Não foi capaz - e nem se propôs, é importante frisar -, entretanto, de oferecer respostas além dessa escala local: o programa, de um lado, não interferiu na questão da relação dos conjuntos com o restante da cidade e sua dinâmica, da mesma forma que não avançou sobre as questões diretamente relacionadas à monofuncionalidade e rigidez morfológica e tipológica ali encontradas.

A questão das ocupações das áreas comuns dos condomínios e as transformações das unidades unifamiliares, ambas apropriações irregulares e conflitantes com os projetos originais, enredam-se nas nebulosas atribuições dos diversos órgãos municipais de fiscalização de posturas, uso e ocupação do solo. Evidentemente que essas transformações vão ao encontro de uma demanda facilmente verificável e totalmente reprimida; igualmente evidente é o fato de que uma intervenção que vise à reabilitação de espaços como esses deve oferecer respostas que contemplem a superação do pensamento urbanístico equivocado e já ultrapassado que os produziu, conferindo a esses locais a diversidade e complexidade inerentes àquilo que identificamos como cidade.

A reabilitação dos perímetros dos grandes conjuntos habitacionais, é importante frisar, deve passar pela sua integração - física, econômica e social - à dinâmica urbana metropolitana, transcendendo seus limites. Mesmo internamente aos conjuntos, faz-se fundamental enfrentar as irregularidades no uso e ocupação do solo, reflexo da 
incompatibilidade entre o projetado e o vivido nesses espaços. A excessiva rigidez e pobreza morfológica aí presentes devem tornar-se alvos de propostas de requalificação que vão até o nível da edificação, com o que se poderia atingir um elevado grau de melhoria urbanística.

Estas observações não diminuem a importância e relevância do Viver Melhor enquanto política pública de redução das desigualdades socioespaciais nos conjuntos, enfocando especificamente a questão do subequipamento de áreas, paradoxalmente, planejadas, projetadas e executadas pelo poder público. Este representou, verdadeiramente, um primeiro passo com vistas à garantia plena do acesso à cidade aos residentes em conjuntos da COHAB-SP; passo este que deve ser complementado com outras ações que objetivem a completa integração dessas áreas à cidade consolidada.

Evidentemente, mesmo uma política ampla e integrada, enfocando a reabilitação dos conjuntos em todas as suas dimensões, teria limitações ao enfrentar a questão da segregação socioespacial e da alienação urbanas. Por atuar eminentemente na esfera do consumo do espaço, essas ações pouco interferem nos elementos que agem na produção dessa realidade, impactando marginalmente as condições de segregação. A experiência francesa de reabilitação dos grandes conjuntos expressa isso à perfeição, onde décadas de vultosos investimentos e projetos competentes não foram capazes de alterar a realidade de segregação desses territórios, ainda que a qualidade de vida (representada por um grau bastante significativo de equipamentos e serviços urbanos) tenha se ampliado.

Essa reflexão final não pretende conduzir à inação devido à impossibilidade da superação completa da segregação por meio de políticas públicas desse tipo; pelo contrário, pretende defender a necessidade de mais e melhores políticas e ações do poder público que, se são embaraçadas por limites bastante claros e evidentes, ao mesmo tempo têm a possibilidade de melhorar as condições objetivas de vida de milhares de famílias que habitam as periferias das cidades brasileiras e os conjuntos habitacionais, em particular. 
REFERÊNCIAS BIBLIOGRÁFICAS 


\section{REFERÊNCIAS BIBLIOGRÁFICAS}

ALMEIDA, Altemir A. de e FRANCO, André F. (Coord.). Programa Viver Melhor. São Paulo: COHAB-SP/PMSP, 2004.

ANDRADE, Carlos R. M. de, BONDUKI, Nabil e ROSSETTO, Rossella (Org.). Arquitetura e Habitação Social em São Paulo, 1989-1992. São Paulo: USP/EESC, 1993.

AZEVEDO, Sérgio e ANDRADE, Luís Aureliano Gama de. Habitação e Poder: da Fundação da Casa Popular ao Banco Nacional da Habitação. Rio de Janeiro: Zahar, 1982.

BENEVOLO, Leonardo. História da Cidade. São Paulo: Perspectiva, 2007.

BENEVOLO, Leonardo. História da Arquitetura Moderna. São Paulo: Perspectiva, 2006.

BENEVOLO, Leonardo. O Último Capítulo da Arquitetura Moderna. Lisboa: Edições 70, 1997.

BLOS, Dorotea. Los Polígonos de Vivienda Social: perspectivas hacia su recuperación en España, Francia y Brasil. Tese de doutorado apresentada à Escola Técnica Superior de Arquitectura de Barcelona / Universitat Politècnica de Catalunya. Barcelona: ETSAB/UPC, 1999.

BOLAFFI, Gabriel. Habitação e urbanismo: o problema e o falso problema. in MARICATO, Ermínia (Org.). A produção capitalista da casa (e da cidade) no Brasil Industrial. São Paulo: Alfa-Ômega, 1982.

BONDUKI, Nabil G. Origens da Habitação Social no Brasil - Arquitetura Moderna, Lei do Inquilinato e Difusão da Casa Própria. São Paulo: Estação Liberdade, 1999.

BONDUKI, Nabil G. Affonso Eduardo Reidy. Lisboa; São Paulo: Editorial Blau; Instituto Lina Bo e P. M. Bardi, 1999.

BOTELHO, Adriano. O financiamento e a financeirização do setor imobiliário: uma análise da produção do espaço e da segregação sócio-espacial através do estudo do mercado da moradia na cidade de São Paulo. Tese de doutorado apresentada à FFLCH. São Paulo: FFLCH, 2005.

BOUCHÉ, Nancy. A Reabilitação na França - Instrumentos e Procedimentos. In: Apostila do Curso Gestão de Programas de Reabilitação Urbana. São Paulo: LABHAB/FAUUSP, 2000.

BOURDIEU, Pierre (Coord.). A Miséria do Mundo. Petrópolis: Vozes, 2007.

BOURDIEU, Pierre. A demissão do Estado in BOURDIEU, Pierre (Coord.). A Miséria do Mundo. Petrópolis: Vozes, 2007.

BRUAND, Yves. Arquitetura Contemporânea no Brasil. São Paulo: Perspectiva, 1997.

BRUNA, Paulo J. V. Arquitetura, industrialização e desenvolvimento. São Paulo: tese de doutoramento apresentada à FAUUSP: FAUUSP, 1972. 
CALDEIRA, Teresa Pires do Rio. Cidade de Muros: crime, segregação e cidadania em São Paulo. São Paulo: EDUSP: 34, 2000.

CAMARGo, Mônica Junqueira de. Joaquim Guedes. São Paulo: Cosac \& Naify, 2000, p. 100-109.

CASTELLS, Manuel. La Ciudad y las Masas: Sociología de los Movimientos Sociales Urbanos. Madrid: Alianza Editorial, 1983.

CASTRO, Roland. Suburbios 89: una Gran Apuesta in Revista Ciudad y Territorio, No 72/73, abril-septiembre 1987.

CESAD-FAUUSP. MSPQ - Mapa Vetorial de Quadras Município de São Paulo. São Paulo, CESAD-FAUUSP, 2004.

CHAFFUN, Nelson. Dinâmica Global e Desafio Urbano, in BONDUKI, Nabil G. Habitat: as práticas bem sucedidas em habitação, meio ambiente e gestão urbana nas cidades brasileiras. São Paulo, Studio Nobel, 1997.

ChAMPAGNE, Patrick. A visão mediática in BoURDIEU, Pierre (Coord.). A Miséria do Mundo. Petrópolis: Vozes, 2007a.

CHAMPAGNE, Patrick. Uma família integrada in BOURDIEU, Pierre (Coord.). A Miséria do Mundo. Petrópolis: Vozes, 2007b.

CHOAY, Françoise. O Urbanismo: utopias e realidades - uma antologia. São Paulo: Perspectiva, 1997.

COHAB-SP. Programa Viver Melhor. São Paulo: COHAB-SP/PMSP, s/d (mimeo).

Convention Territoriale. Grand Projet de Ville: Clichy-sous-Bois/Montfermeil 2001-2006. Bobigny, 2000. Acessado e baixado do site da Municipalidade de Clichy-sous-Bois em 4 de novembro de 2008: http://www.clichy-sousbois.fr/jsp/site/Portal.jsp?page_id=20.

COULON Jean-Yves. Financiamento Francês da Reabilitação. In: Apostila do Curso Gestão de Programas de Reabilitação Urbana. São Paulo: LABHAB/FAUUSP, 2000.

DAMIANI, Amélia Luisa. A cidade (des)ordenada: concepção e cotidiano do conjunto habitacional Itaquera I. Tese de doutorado apresentada à FFLCH/USP Departamento de Geografia. São Paulo: FFLCH/USP, 1993.

Department of the Environment, Scottish Development Department, Welsh Office and Central Office of Information. The New Towns. Londres: Curwen Press, 1973.

DíAZ, Jesús López. La Vivienda Social en Madrid in Revista Espacio, Tiempo y Forma, Serie VII, Historia del Arte, $\mathrm{n}^{\circ}$ 15. UNED, 2002.

ENGELS, Friedrich. A Situação da Classe Trabalhadora na Inglaterra. São Paulo: Boitempo, 2008.

FARAH, Marta Ferreira dos Santos. Público e Privado na Provisão de Habitação nos Países Centrais. Revista Espaço e Debates 31. São Paulo: NERU, 1990. 
FARAH, Marta Ferreira dos Santos. Estado, previdência social e habitação. Dissertação de Mestrado apresentada à FFLCH/USP - Departamento de Ciências Sociais. São Paulo: FFLCH/USP, 1983.

FERREIRA, João Sette Whitaker. O Mito da Cidade-Global: o papel da ideologia na produção do espaço urbano. Petrópolis: Vozes: Unesp: Anpur, 2007.

FINEPIGAP. Habitação Popular: inventário da ação governamental. São Paulo: FINEP, Projeto, 1983.

FONSECA, Francisco. "O Consenso Forjado". São Paulo: Hucitec, 2005.

FOURCAUT, Annie. Trois discours, une politique? Revista Urbanisme nº 322, jan/fev 2002.

FRAMPTON, Kenneth. História Crítica da Arquitetura Moderna. São Paulo: Martins Fontes, 2003.

GÖSSEL, Peter e LEUTHÄUSER, Gabriele. Arquitectura no Século XX. Colônia: Taschen, 1996.

HARBURGER, Sylvie. El Programa Francés de Desarrollo Social de los Barrios in Revista Ciudad y Territorio, No 72/73, abril-septiembre 1987.

INE - Instituto Nacional de Estadística. Censos de Población desde 1900: Censos de 1950, 1960 y 1970. Acessado em 26 de setembro de 2008 e baixado do sítio do INE do endereço: http://www.ine.es/inebaseweb/71807.do?language $=0$.

JACOBS, Jane. Morte e vida de grandes cidades. São Paulo: Martins Fontes, 2000.

JENCKS, Charles. The Language of Post-Modern Architecture. London: Academy Editions, 1978.

KOPP, Anatole. Quando o moderno não era um estilo e sim uma causa. São Paulo: Nobel, 1990.

LAMAS, José Manuel Ressano Garcia. Morfologia Urbana e Desenho da Cidade. Porto: Fundação Calouste Gulbenkian: Fundação para a Ciência e Tecnologia, 2007.

LEFEBVRE, Henri. Espaço e Política. Belo Horizonte: Editora UFMG, 2008.

LEFEBVRE, Henri. O Direito à Cidade. São Paulo: Centauro, 2001.

LEFEBVRE, Henri. A Revolução Urbana. Belo Horizonte: Editora UFMG, 1999.

Lei Federal 4.380, de 21 de agosto de 1964.

Lei Municipal n 13.430, de 13 de setembro de 2002.

Lei Municipal no 13.885, de 25 de agosto de 2004.

LEITE, Eleilson. Semeando asas na quebrada paulistana in Le Monde Diplomatique Brasil, junho de 2008.

MALUENDA, Ana María Esteban. La vivienda social española en la década de los 50: un paseo por los poblados dirigidos de Madrid. Cuaderno de Notas 7. Madrid: ETSAM/UPM, 1999. 
MARCUSE, Peter. Enclaves, sim; Guetos, não: a Segregação e o Estado. Revista Espaço e Debates 45. São Paulo: NERU, 2004.

MARICATO, Ermínia. Metrópole na periferia do Capitalismo: ilegalidade, desigualdade e violência. São Paulo: Hucitec, 1996.

MARICATO, Ermínia. Política Habitacional no Regime Militar: do milagre brasileiro à crise econômica. Petrópolis: Vozes, 1987.

MARICATO, Ermínia. Indústria da Construção e Política Habitacional. São Paulo: São Paulo: Tese de doutorado apresentada à FAUUSP, 1984.

MARICATO, Ermínia. Autoconstrução: a Arquitetura Possível in MARICATO, Ermínia (Org.). A produção capitalista da casa (e da cidade) no Brasil Industrial. São Paulo: Alfa-Ômega, 1982.

MARICATO, Ermínia (Org.). A produção capitalista da casa (e da cidade) no Brasil Industrial. São Paulo: Alfa-Ômega, 1982.

MARQUES, Eduardo e TORRES, Haroldo (Org.). São Paulo: segregação, pobreza e desigualdades sociais. São Paulo: SENAC, 2005.

MARQUES, Eduardo e SARAIVA, Camila. As políticas de habitação social, a segregação e as desigualdades na cidade in MARQUES, Eduardo e TORRES, Haroldo (Org.). São Paulo: segregação, pobreza e desigualdades sociais. São Paulo: SENAC, 2005.

MARQUES, Eduardo. Elementos Conceituais da Segregação, da Pobreza Urbana e da Ação do Estado in MARQUES, Eduardo e TORRES, Haroldo (Org.). São Paulo: segregação, pobreza e desigualdades sociais. São Paulo: SENAC, 2005a.

MARQUES, Eduardo. Espaço e Grupos Sociais na Virada do Século XXI in MARQUES, Eduardo e TORRES, Haroldo (Org.). São Paulo: segregação, pobreza e desigualdades sociais. São Paulo: SENAC, 2005b.

MARTINS, Maria Lúcia Refinetti. Moradia e Mananciais: Tensão e diálogo na metrópole. São Paulo: FAUUSP/FAPESP, 2006.

MARTINS, Maria Lúcia Refinetti. BNH: limitações e perspectivas. Trabalho Final de Graduação apresentado à Faculdade de Arquitetura e Urbanismo da Universidade de São Paulo. São Paulo: FAUUSP, 1974.

MARX, Karl. O Capital: crítica da economia política. Livro 1, Volume 2. Rio de Janeiro: Civilização Brasileira, 2006.

MARX, Karl e ENGELS, Friederich. Manifesto Comunista. São Paulo: Boitempo, 2007.

MONTANER, Josep Maria. Depois do Movimento Moderno: Arquitetura da Segunda Metade do Século XX. Barcelona: Gustavo Gili, 2001.

NAKANO, A. K. 4 COHABs da Zona Leste de São Paulo: território, poder e segregação. Dissertação de Mestrado apresentada à Faculdade de Arquitetura e Urbanismo da Universidade de São Paulo. São Paulo: FAUUSP, 2002. 
NEGRELOS, Eulalia Portela. Remodelação de Bairros Populares em São Paulo e Madrid 1976-1992: Projeto e Participação Popular. Dissertação de Mestrado apresentada à FAUUSP. São Paulo: FAUUSP, 1998.

OLIVEIRA, Francisco. Crítica à Razão Dualista: o Ornitorrinco. São Paulo: Boitempo, 2003.

OLIVEIRA, Francisco. O Estado e o Urbano no Brasil in Revista Espaço e Debates $n^{\circ} 6$, junho/setembro de 1982.

ORNSTEIN, Sheila Walbe e ROMÉRO, Marcelo de Andrade. Avaliação Pós-Ocupação: métodos e técnicas aplicados à habitação social (Coleção Habitare/FINEP). Porto Alegre: ANTAC, 2003.

PRADO JR., Caio. Formação do Brasil Contemporâneo. São Paulo: Brasiliense, 2007.

PRÉTECEILLE, Edmond. A construção social da segregação urbana: convergências e divergências in Revista Espaço \& Debates 45 - Segregações Urbanas. São Paulo: Neru - jan/jul - 2004.

RECAMÁN, Luiz. Forma sem Utopia. 2003. Artigo acessado e baixado do site "http://www.la2.com.br/textos.html".

ROLNIK, Raquel. A Cidade e a Lei: legislação, política urbana e territórios na cidade de São Paulo. São Paulo: Nobel: Fapesp, 2003.

ROYER, Luciana de Oliveira. Política habitacional no Estado de São Paulo: estudo sobre a Companhia de Desenvolvimento Habitacional e Urbano do Estado de São Paulo, CDHU. Dissertação de Mestrado apresentada à Faculdade de Arquitetura e Urbanismo da Universidade de São Paulo. São Paulo: FAU USP, 2002.

RUBANO, Lizete Maria. Cultura de projeto: um estudo das idéias e propostas para habitação coletiva. Tese de doutorado apresentada à Faculdade de Arquitetura e Urbanismo da Universidade de São Paulo. São Paulo: FAUUSP, 2001.

SACHS, Céline. São Paulo: Políticas públicas e habitação popular. São Paulo: EDUSP, 1999.

SÂO PAULO (cidade). Secretaria Municipal de Planejamento - SEMPLA. Planos Regionais Estratégicos - Subprefeitura Cidade Tiradentes. São Paulo: PMSP/SEMPLA, 2004.

SÂO PAULO (cidade). Secretaria Municipal de Planejamento - SEMPLA. Departamento de Estatística e Produção da Informação - DIPRO. Olhar São Paulo - contrastes urbanos. São Paulo: PMSP/SEMPLA, 2007.

SÂO PAULO (cidade). Secretaria Municipal de Trabalho. Atlas do Trabalho e Desenvolvimento da Cidade de São Paulo. São Paulo: PMSP/SMT, 2007. Acessado e baixado em 22 de novembro de 2008 do site da Secretaria Municipal de Trabalho:

http://portal.prefeitura.sp.gov.br/secretarias/trabalho/atlasmunicipal/relatorios/0001.

SEGAWA, Hugo. Oswaldo Arthur Bratke. São Paulo: ProEditores, 1997.

SEMPLA/DIPRO - Secretaria Municipal de Planejamento/Departamento de Estatística e Produção de Informação - Prefeitura do Município de São Paulo. Histórico 
Demográfico do Município de São Paulo. Acessado do sítio http://sempla.prefeitura.sp.gov.br/historico/ em 27 de fevereiro de 2008.

SEMPLA/DIPRO - Secretaria Municipal de Planejamento/Departamento de Estatística e Produção de Informação - Prefeitura do Município de São Paulo. Município em Dados. Acessado do sítio http://www9.prefeitura.sp.gov.br/sempla/md/ em 27 de fevereiro de 2008.

SEMPLA/DIPRO - Secretaria Municipal de Planejamento/Departamento de Estatística e Produção de Informação - Prefeitura do Município de São Paulo. Município em Mapas - Panorama. Acessado do sítio http://sempla.prefeitura.sp.gov.br/mm/panorama/ em 19 de novembro de 2008.

SILVA, Helena Menna Barreto. Políticas de Habitação e Preço da Terra in Revista Oculum Ensaios - dezembro de 2000. Campinas: FAU PUCCAMP, 2000.

SILVA, Maria da Graça Plenamente. A "irregularidade" na produção de conjuntos habitacionais de interesse social: o caso da COHAB-SP. Dissertação de mestrado apresentada à Faculdade de Arquitetura e Urbanismo da Universidade de São Paulo. São Paulo: FAUUSP, 2004.

SLOMIANSKY, Adriana Paula. Cidade Tiradentes: a abordagem do poder público na construção da cidade - conjuntos habitacionais de interesse social da COHAB-SP. Tese de doutorado apresentada à Faculdade de Arquitetura e Urbanismo da Universidade de São Paulo. São Paulo: FAUUSP, 2002.

SPTrans. Expresso Tiradentes: corredor Parque D. Pedro II - Cidade Tiradentes. São Paulo: SPTrans, 2006.

TAFURI, Manfredo. Projecto e Utopia: arquitectura e desenvolvimento do capitalismo. Lisboa: Presença, 1985.

USINA-Ctah. Programa Bairro Legal: Plano de Ação Habitacional e Urbano Diagnóstico. São Paulo: SEHAB/PMSP, 2003.

VILLAÇA, Flávio. As Ilusões do Plano Diretor. São Paulo: FV, 2005.

VILLAÇA, Flávio. Espaço Intra-urbano no Brasil. São Paulo: Nobel, 2001.

VILLAÇA, Flávio. Uma contribuição à história do planejamento urbano no Brasil in DEAK, Csaba; SCHIFFER, Sueli Ramos, (Orgs.) O processo de urbanização no Brasil. São Paulo: EDUSP, 1999.

VINUESA, Julio, SÁNCHEZ-FAYOS, Teresa e OLIETE, Ana. La Operación de Remodelación de Barrios en Madrid in Revista Ciudad y Territorio, № 68, abril-junio 1986.

ZANDONADE, Patrícia. Conjuntos Habitacionais no Tecido Urbano da Metrópole de São Paulo: o caso da Região Leste (1930/1986). Dissertação de mestrado apresentada à Faculdade de Arquitetura e Urbanismo da Universidade de São Paulo. São Paulo: FAUUSP, 2008. 


\section{ARTIGOS EM JORNAIS}

EL PAIS. Francia fracasa en su política de integración in www.elpais.com, 06/11/2005. Acessado no

sítio "http://www.elpais.com/articulo/internacional/Francia/fracasa/politica/integracion/elpe piint/20051106elpepiint_2/Tes" em 04 de novembro de 2008.

DEUTSCHE WELLE. Arquitetura ou Revolução? in www.dw-world.de, 15/11/2005. Acessado no sítio "http://www.dw-world.de/dw/article/0,2144,1777969,00.html" em 13 de janeiro de 2008.

FOLHA DE SÃo PAULO. ITAPEVI É O MAIOR CONJUNTO DA COHAB A SER DEMOLIDO in Folha de São Paulo, 2 de maio de 1991, p. 4.1.

FOLHA DE SÃo PAULO. CATÁSTROFE AMBIENTAL IMINENTE, 18 de agosto de 1989, p. D-3 (Anúncio publicitário).

O ESTADO DE SÃo PAULO. Erosão em conjunto terá punição in O Estado de São Paulo, 3 de julho de 1989, p. 19.

O ESTADO DE SÃO PAULO. Cohab: imóveis precários e irregulares in O Estado de São Paulo, 19 de abril de 1986.

O ESTADO DE SÃo PAULO. Risco de vida nos conjuntos da Cohab in O Estado de São Paulo, 7 de abril de 1986, p. 28.

FOLHA DE SÃo PAULO. Conjunto da Cohab é inabitável, dizem moradores in Folha de São Paulo, 6 de janeiro de 1984, p. 18.

JORNAL DA TARDE. Veja o que a chuva (e o governo) fez in Jornal da Tarde, 17 de junho de 1983, p. 14.

O ESTADO DE SÃo PAULO. Jardim Sapopemba, um conjunto isolado de tudo in O Estado de São Paulo, 15 de maio de 1983, p. 25.

O ESTADO DE SÃO PAULO. Moradores de Carapicuíba reclamam in O Estado de São Paulo, 13 de maio de 1983, p. 15.

O ESTADO DE SÃo PAULO. Sem acessos, conjunto não pode ser ocupado na região Leste in O Estado de São Paulo, 29 de março de 1983, p. 43.

FOLHA DE SÃo PAULO. Cohab dá chave sem água e sem luz in Folha de São Paulo, 21 de outubro de 1982, p. 19.

FOLHA DE SÃo PAULO. Conjunto da Cohab na região Leste está abandonado in Folha de São Paulo, 18 de junho de 1982, p. 12.

O ESTADO DE SÃo PAULO. Reynaldo ataca a oposição: é rançosa e nada faz in O Estado de São Paulo, 14 de fevereiro de 1982, p. 5.

FOLHA DE SÃo PAULO. A Cohab constrói uma nova cidade in Folha de São Paulo, 30 de junho de 1981, p. 10. 


\section{SITES CONSULTADOS}

Marxists Internet Archive (Arquivos Marxistas na Internet)

http://www.marxists.org

\section{Deutsche Welle}

http://www.dw-world.de

\section{El País}

http://www.elpais.com

Secretaria Municipal de Planejamento da Prefeitura do Município de São Paulo http://sempla.prefeitura.sp.gov.br

Secretaria Municipal de Saúde da Prefeitura do Município de São Paulo http://portal.prefeitura.sp.gov.br/secretarias/saude

Secretaria Municipal de Trabalho da Prefeitura do Município de São Paulo http://portal.prefeitura.sp.gov.br/secretarias/trabalho/

\section{Prefeitura do Município de São Paulo}

http://www.prefeitura.sp.gov.br

Instituto Nacional de Estadística (Instituto Nacional de Estatística da Espanha)

http://www.ine.es

Institut National de la Statistique et des Études Économiques (Instituto Nacional da Estatística e dos Estudos Econômicos da França)

www.insee.fr

Financiadora de Estudos e Projetos

http://www.finep.gov.br

Instituto Brasileiro de Geografia e Estatística

http://www.ibge.gov.br

Tesis Doctorals en Xarxa (Teses de Doutorado em Rede, Espanha)

http://www.tesisenxarxa.net

Mairie de Clichy-sous-Bois (Prefeitura de Clichy-sous-Bois, França)

http://www.clichy-sous-bois.fr

Ministère du Logement et de la Ville (Ministério da Habitação e da Cidade da França) http://www.ville.gouv.fr

\section{LA2 Arquitetura}

http://www.la2.com.br

SEADE - Fundação Sistema Estadual de Análise de Dados

http://www.seade.gov.br 


\section{ENTREVISTAS}

\section{Margareth Matiko Uemura}

Ex-Coordenadora Técnica do Programa Viver Melhor entre 2001 e 2002

Entrevista realizada em 30 de março de 2007.

Local: São Paulo

\section{Suely Muniz}

Ex-Presidente da COHAB-SP em 2004

Ex-Diretora Financeira da COHAB-SP entre 2001 e 2004

Entrevista realizada em 28 de março de 2008.

Local: São Paulo

\section{Vladimir Bartalini}

Ex-Gerente de Projetos da COHAB-SP entre 1989 e 1992

Entrevista realizada em 17 de abril de 2008.

Local: São Paulo

\section{Altemir Almeida}

Ex-Diretor de Patrimônio da COHAB-SP entre 2001 e 2004

Entrevista realizada em 3 de setembro de 2008.

Local: São Paulo

\section{Renata Milanesi}

Técnica da COHAB-SP

Entrevista realizada em 29 de dezembro de 2008.

Local: São Paulo 